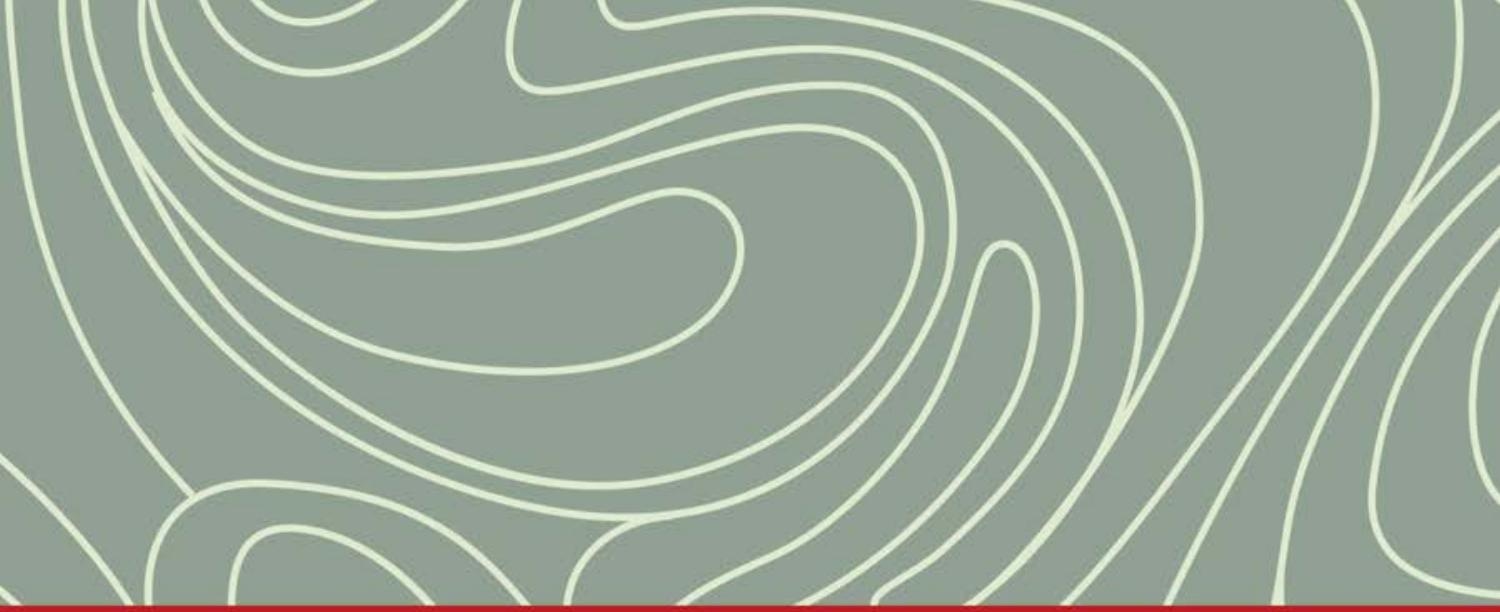

Routledge Studies in the Modern History of Africa

\title{
WOMEN'S LIVED \\ LANDSCAPES OF WAR AND \\ LIBERATION IN MOZAMBIQUE
}

BODILY MEMORY AND THE GENDERED AESTHETICS OF BELONGING

Jonna Katto

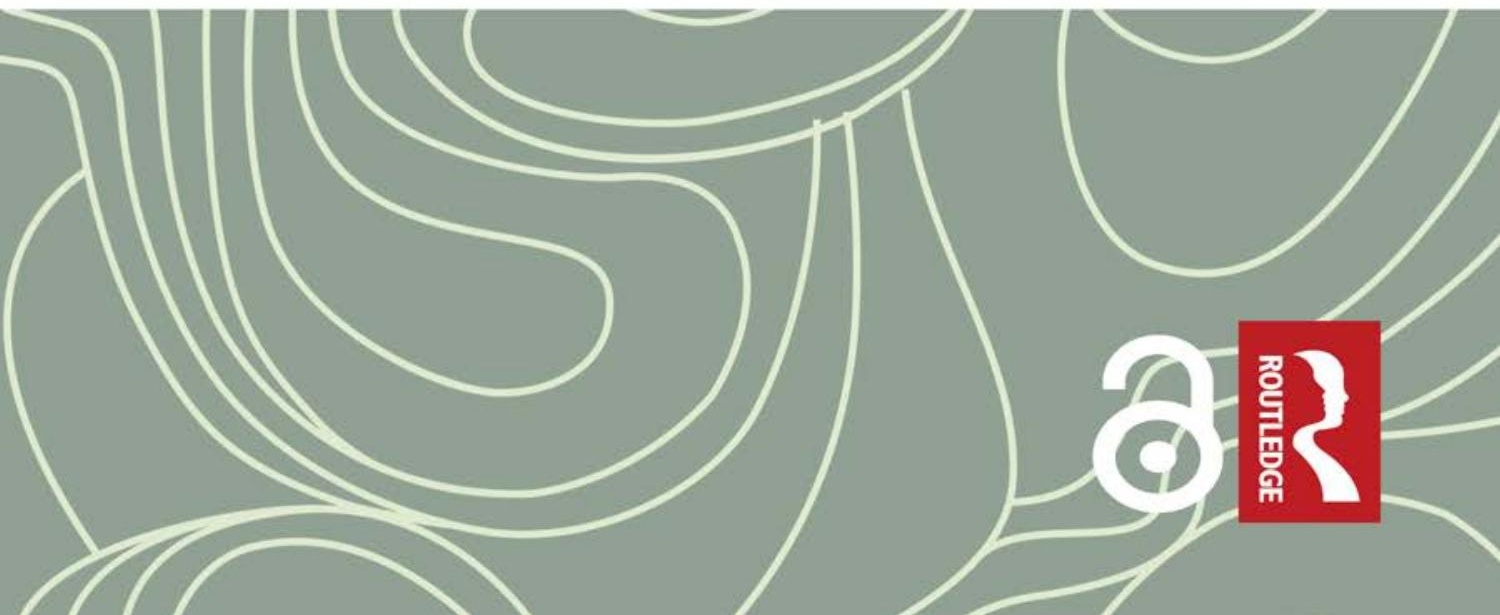




\section{Women's Lived Landscapes of War and Liberation in Mozambique}

This book tells the history of the changing gendered landscapes of northern Mozambique from the perspective of women who fought in the armed struggle for national independence, diverting from the often-told narrative of women in nationalist wars that emphasizes a linear plot of liberation.

Taking a novel approach in focusing on the body, senses, and landscape, Jonna Katto, through a study of the women ex-combatants' lived landscapes, shows how their life trajectories unfold as nonlinear spatial histories. This brings into focus the women's shifting and multilayered negotiations for personal space and belonging. This book explores the life memories of the now aging female ex-combatants in the province of Niassa in northern Mozambique, looking at how the female ex-combatants' experiences of living in these northern landscapes have shaped their sense of socio-spatial belonging and attachment. It builds on the premise that individual embodied memory cannot be separated from social memory; personal lives are culturally shaped. Thus, the book does not only tell the history of a small and rather unique group of women but also speaks about wider cultural histories of body-landscape relations in northern Mozambique and especially changes in those relations.

Enriching our understanding of the gendered history of the liberation struggle in Mozambique and informing broader discussions on gender and nationalism, this book will be of interest to students and scholars of African history, especially the colonial and postcolonial history of Lusophone Africa, as well as gender/women's history and peace and conflict studies.

Jonna Katto is Postdoctoral Researcher in African Studies at the Department of Languages and Cultures at Ghent University, Belgium. 


\section{Routledge Studies in the Modern History of Africa}

This series includes in-depth research on aspects of economic, political, cultural and social history of individual countries as well as broad-reaching analyses of regional issues.

Themes include social and economic change, colonial experiences, independence movements, post-independence governments, globalisation in Africa, nationalism, gender histories, conflict, the Atlantic Slave trade, the environment, health and medicine, ethnicity, urbanisation, and neo-colonialism and aid.

\section{Forthcoming titles:}

Human Rights in Sierra Leone, 1787-2016

The Long Struggle from the Transatlantic Slave Trade to the Present John Idriss Lahai

Miscegenation, Identity and Status in Colonial Africa Intimate Colonial Encounters

Lawrence Mbogoni

\section{Displaced Mozambicans in Postcolonial Tanzania}

Refugee Power, Mobility, Education, and Rural Development Joanna T. Tague

\section{Africans and the Holocaust}

Perceptions and Responses of Colonized and Sovereign Peoples

Edward Kissi

\section{Photography and History in Colonial Southern Africa}

Shades of Empire

Lorena Rizzo

\section{Women's Lived Landscapes of War and Liberation in Mozambique}

Bodily Memory and the Gendered Aesthetics of Belonging Jonna Katto

For a full list of titles in this series, please visit www.routledge.com 


\title{
Women's Lived Landscapes of War and Liberation in Mozambique
}

Bodily Memory and the Gendered Aesthetics of Belonging

\author{
Jonna Katto
}


First published 2020

by Routledge

2 Park Square, Milton Park, Abingdon, Oxon OX14 4RN

and by Routledge

52 Vanderbilt Avenue, New York, NY 10017

Routledge is an imprint of the Taylor \& Francis Group, an informa business

(C) 2020 Jonna Katto

The right of Jonna Katto to be identified as author of this work has been asserted by her in accordance with sections 77 and 78 of the Copyright, Designs and Patents Act 1988.

The Open Access version of this book, available at www.taylorfrancis.com, has been made available under a Creative Commons Attribution-Non Commercial-No Derivatives 4.0 license.

Trademark notice: Product or corporate names may be trademarks or registered trademarks, and are used only for identification and explanation without intent to infringe.

British Library Cataloguing-in-Publication Data

A catalogue record for this book is available from the British Library

Library of Congress Cataloging-in-Publication Data

A catalog record for this book has been requested

ISBN: 978-0-367-25247-2 (hbk)

ISBN: 978-0-429-28935-4 (ebk)

Typeset in Bembo

by Apex CoVantage, LLC 
To Helena 
$\because$ Taylor \& Francis Taylor \& Francis Group http://taylorandfrancis.com 


\section{Contents}

List of illustrations $\quad$ ix

Acknowledgments $\quad x$

Introduction: gendered bodies, moving landscapes, and spatial histories

\section{PART I}

Talking freedom

1 FRELIMO nationalism, female bodies, and the language of gender

\section{PART II}

Violent liberation

2 Female combatants and gendered styles of being 79

3 Guerrilla life and the haptics of the "bush" 96

4 Body feelings and violent memories 117

\section{PART III}

\section{Beautiful belonging}

5 Living landscape

6 Rhythmic beauty 181

7 Home, (be)longing, and the beautiful 222

Epilogue: spatial movements, relations, and representations 230 
viii Contents

Bibliography 235

Glossary and abbreviations $\quad 257$

Transcription symbols 258

$\begin{array}{ll}\text { Index } & 259\end{array}$ 


\section{Illustrations}

\section{Maps}

$0.1 \mathrm{a} / \mathrm{b} \quad$ Research sites in Niassa/research site in relation to the larger geographic space of southern Africa $\quad 10$

0.2 The East African region 19

$0.3 \quad$ Nyassa Company 25

3.1 FRELIMO's principal military bases in Niassa during the war 100

6.1a/b The multiple places of Helena's and Fátima's life 183

6.2 Lúcia's homeplaces after the war 189

6.3a/b City of Lichinga/central bairros of Lichinga 206

\section{Figures}

$0.1 \quad$ Orienting 1

2.1 $\mathrm{a} / \mathrm{b} \quad$ Masculine and feminine styles $\quad 84$

$2.1 \mathrm{c} / \mathrm{d} \quad$ Masculine and feminine styles 85

3.1 The "historical locale" of Base Beira in N'kalapa, Mavago 100

3.2 Retracing old footsteps and making new paths in Mavago 102

3.3 Deadly fruits 109

I.1 Rice harvest time in Macaloge 125

5.1 Tomb of Ce-N'tamila II 132

6.1a/b No street lights are needed/appreciating the fresh air after the rain 186

6.2a/b Undesirable landscape in Macaloge/desirable rhythms of homeplace 


\section{Acknowledgments}

Doing and writing this research has been a long and winding journey, and I wish to thank the many people who in different places and at different moments of this project have offered support and encouragement.

My sincerest gratitude goes to everyone who participated in the research and so generously shared their time, ideas, and experiences with me. I especially thank all the members of the female detachment (DFs) for their engagement in the project. I also thank my Yaawo language research assistant Bernardo Aubi Silajo for his invaluable help and his whole family in Lichinga for their embracing hospitality and friendship. Moreover, I extend my deepest gratitude to my co-interviewer Helena Baide for her untiring support and dedication to this research and for teaching me so much during our travels around northern Niassa.

The book developed out of my doctoral dissertation in the Department of Cultures at the University of Helsinki, and I am greatly indebted to Axel Fleisch, Tuija Saresma, and Isabel Maria Casimiro for their encouragement and critical feedback and, especially, for allowing me the freedom and space to think creatively beyond disciplinary boundaries. I also owe a very special thank you to Signe Arnfred, Inge Brinkman, Gerhard Liesegang, and Kathleen Sheldon for their careful and insightful reading of an earlier version of the manuscript. Throughout this research project, I have been inspired, challenged, guided, supported, and shown kindness by numerous people in so many different ways. I thank, especially, Henni Alava, Lotta Aunio, Bjørn Enge Bertelsen, Liazzat J. K. Bonate, Jan Van den Broeck, Catarina Costa, Lotta Gammelin, Viveca Hedengren, Tobias and Heather Houston, Victor Igreja, Paulo Israel, Lena Kalmelid, Kalle Kananoja, Liisa Korkalo, Ana Leão, Gun Lindberg and Per-Olof Nilsson, Virginia Mariezcurrena, Cubilas Messope, Emilia Miettinen, Lúcia Mustaffa, Geraldina Valerio Mwito, Anu Mäkinen, Armindo Ngunga, Humberto Ossemane, Ritva Parviainen, Pekka Peltola, José Alberto Raimundo, Janne Rantala, Teija Rantala, Thera Crane Ringhofer, Alda Saúte Saide, Nyellett Sarea, Ana Santos Silva, Annika Teppo, Minna Tuominen, and Benigna Zimba. During the very final stage of this manuscript, I began a postdoctoral fellowship at the Department of Languages and Cultures at Ghent University, and I thank my colleagues there for their support. 
The Centro de Estudos Africanos (CEA) at Universidade Eduardo Mondlane (UEM) served as my institutional home in Mozambique, and I thank the staff and faculty for all their support. My research was facilitated by the Centro de Pesquisa da História da Luta de Libertação Nacional at the Ministry of Combatants and the Association of the Former Combatants of the Liberation Struggle (Associação dos Combatentes da Luta de Libertação Nacional, ACLLN), and I sincerely thank everyone for their very generous hospitality and assistance in Maputo and Lichinga, as well as the districts of Mavago, Muembe, Sanga, Majune, and Lago.

This research would not have been possible without the financial support of several institutions. I sincerely thank the Finnish Cultural Foundation, the Ryoichi Sasakawa Young Leaders Fellowship Fund, the Nordic Africa Institute, and the University of Helsinki.

Finally, I thank all my friends and my family for their support and loving care. I especially thank Bartosz Kopczyński for being there through thick and thin, for taking me on excursions to the forest, and for always encouraging, listening, and believing.

Some material in this book was originally published elsewhere. I wish to thank the following for permission to reprint copyrighted material:

The Oral History Society for short passages from Jonna Katto. "Emotions in Protest: Unsettling the Past in Ex-Combatants' Personal Accounts in Northern Mozambique," Oral History 46, no. 2 (2018): 53-62.

Hurst \& Co. Publishers for the map "Areas of operation of Mozambique concession companies" in Malyn Newitt, A History of Mozambique (London: Hurst and Company, 1994), 366. The Regents of the University of California for the map "The East African region" in Edward A. Alpers, Ivory and Slaves: Changing Pattern of International Trade in East Central Africa to the Later Nineteenth Century (Berkeley: University of California Press, 1975).

The aforementioned maps were redrawn and slightly amended by Noora Katto for this publication.

The other maps and illustrations that wonderfully support the textual narrative in the book are by Noora Katto and Mikko Kankaanpää. I also thank Mikko for editing the photographs. The author took all the photographs. 
$\because$ Taylor \& Francis Taylor \& Francis Group http://taylorandfrancis.com 


\section{Introduction}

\section{Gendered bodies, moving landscapes, and spatial histories}

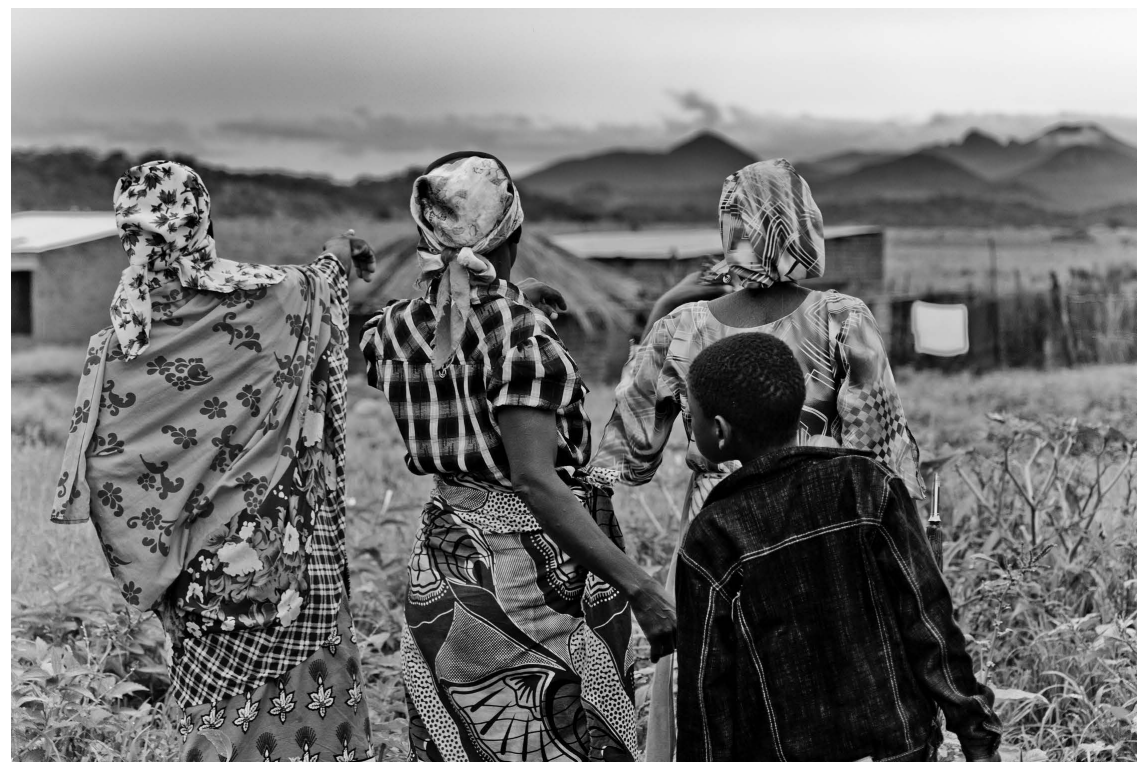

Figure 0.1 Orienting. Fátima, Madiatu, and Helena in Malulu, 2013

The mountain islands that dot an otherwise relatively flat plain are a dominant feature in the physical landscape of northern Niassa. They regulate and direct people's sense of space and their own location in it. Mountains can be seen from very far and bring places that would take days to reach by foot imaginatively closer. Especially for ex-combatants, they embody memories of wartime footpaths and movement. Often, on our interview trips in the rural areas of northern Niassa, Helena, my co-interviewer (herself also an ex-combatant), and the female ex-combatants we were visiting would start talking about the mountain landscape that opened up around the women's homes. Pointing toward and indicating different mountains by name, they would discuss the relation of these places to their life trajectories: for instance, their childhood places, old military 


\section{Introduction}

bases, old and new machambas (fields), footpaths that they traveled during the war, and, old place-related oral histories of epic wars and great chiefs. Figure 0.1 captures a moment in which Helena, who is originally from Muembe (located on the other side of these mountains), is being taught by Fátima and Madiatu how to interpret the landscape from their situated perspective in Malulu.

This book tells the history of the changing gendered landscapes of northern Mozambique from the perspective of female ex-combatants who, like Helena, Fátima, and Madiatu, fought in the armed struggle for national independence. Led by the Mozambique Liberation Front (FRELIMO) ${ }^{1}$ against Portuguese colonial rule, this war was mainly waged in the bush thickets of the northernmost parts of the country, more than 2,000 km away from the southern capital Maputo (or Lourenço Marques at the time). Throughout the ten-year (1964-1974) war, FRELIMO mobilized thousands of youths from the rural villages of the north to participate as soldiers in its political-military campaign. Hundreds of girls also became integrated into the ranks of guerrilla soldiers. Receiving the same military training as their male comrades, the female recruits worked mostly in the transportation of war material and in FRELIMO's bush hospitals and nurseries. To a varying degree, they engaged in direct combat with male soldiers. This book explores the life memories of these now aging female ex-combatants in the province of Niassa in northern Mozambique.

As Niassa was one of FRELIMO's main war fronts during the struggle, its landscapes are intrinsically tied to Mozambique's national history. Yet since independence, the area has been severely marginalized in state politics and spatial practices. Due to its perceived remoteness, Niassa has also received little attention by historians (even in comparison to its neighboring province of Cabo Delgado, also a major war front during the liberation struggle). ${ }^{2}$ Focusing on the northern landscapes of Niassa, this book explores the shifting landscape perceptions in the life narratives of female ex-combatants. It asks how the women's experiences of living in Niassa have shaped their sense of socio-spatial belonging and attachment. How, in their narratives, do the women conceptualize national space and belonging? Moreover, how do they make sense of these abstract ideas in relation to the lived spaces of their life trajectories? And, finally, how do they negotiate the gendered meanings of their various landscapes of belonging?

Women's Lived Landscapes of War and Liberation builds on the premise that individual embodied memory cannot be separated from social memory; personal lives are culturally shaped. Thus this book does not only tell the history of a small and rather unique group of women but also speaks about wider cultural histories of body-landscape relations in northern Mozambique and especially changes in those relations. Moreover, drawing inspiration from Terence Ranger's work on African landscape history, it focuses on the nationalist struggle as a "particular historical moment of contestation and change" 3 in people's landscape perceptions in northern Mozambique. It studies the spatial change-both on the level of political language and the level of material, bodily practices - that the liberation struggle introduced into the lives of the young female recruits and the ways that these changes effected their sense of landscape and spatial belonging. 
What is significant about this book is that it neither tells the history of oppression nor liberation but draws our attention to the complexities of the ex-combatants' experiences and memories, as well as their shifting and multilayered negotiations for personal space and belonging. Thus the book diverts from the often-told narrative of women in nationalist wars that emphasize a linear plot of liberation. Women's Lived Landscapes of War and Liberation takes a novel approach by focusing on the body, senses, and landscape. Through a study of the women ex-combatants' lived landscapes, it shows how their life trajectories unfold as nonlinear spatial histories. Apart from enriching our understanding of the gendered history of the liberation struggle in Mozambique and informing broader discussions on gender and nationalism, this interdisciplinary research contributes to the study of the body and sensory experience in war, moreover, to the study of African landscape histories.

My motivation for this study has its beginning in my research among female ex-combatants in Maputo between 2008 and 2009. At the time, women's military participation in the liberation struggle had not received much attention by historians. ${ }^{4}$ This was largely because the liberation struggle had long been a politically sensitive research topic. During the socialist period, the one-party Frelimo state had tightly regulated the history of the liberation struggle. According to historian Isabel Maria Casimiro, who in the 1980s studied women's participation in the liberation movement, it was very difficult to interview female ex-combatants at the time. Both state censorship (state-imposed silence) and associated self-censorship made ex-combatants cautious of speaking of their war experiences. Research was also hampered by the civil war that commenced soon after independence. However, in 2008, when I started my research among female ex-combatants in Maputo, much had already changed. Two decades of adjusting to multiparty democracy had made the political climate more suitable for research into the topic in question. What is more, the aging ex-combatants themselves had started publishing their war memoirs, determined to leave their life narratives for the future generations of Mozambicans. This signaled a new openness to discuss the country's recent past. These changes in the political climate have also led to an upsurge in critical studies focusing on alternative histories of the liberation war, especially over the last decade. ${ }^{5}$ Still, to date, research has predominantly focused on male experiences, only briefly examining women's various roles in the war campaign; moreover, the gendered meanings and dynamics of FRELIMO nationalism remain relatively underresearched.

Through the course of my research in Maputo, I became interested in the ways that the women's spatial embeddedness in the urban landscape influenced their memories of the liberation war. In many narratives, the former war landscapes of northern Mozambique appeared as nostalgic and distant memories, far removed from the women's lived spaces in Maputo. ${ }^{6}$ The comments of a female ex-combatant called Lúcia especially caught my attention in 2011. By that time, I was already working on a research proposal for my doctoral project, and I was discussing with her my idea of going to visit her childhood homeplace in Chiconono, Niassa. Laughingly, Lúcia spoke of her sense of dislocation from the national landscape whenever she went there for a visit. She 
warned me that by going there to the "bush," I would surely start to question whether I was still in Mozambique. This small conversation stuck with me. I started wondering about the experiences of the female ex-combatants still immersed in the Niassa landscape and their sense of personal and national belonging, as well as the degree that they possibly differed from Lúcia's. While the war experiences of ex-combatants living in urban Maputo and rural Niassa have been similar, their experiences postindependence have been very different. Moreover, due to their spatial locatedness and varying degrees of association with the nationalist elite postindependence, their war memories have been differently framed by Frelimo's political discourse. For instance, in Maputo, Frelimo's gender discourse with its specific concept of gender equality has strongly influenced the female ex-combatants' memories of the war and sense of sociospatial belonging. However, what intrigued me was to find out how national space and belonging are conceptualized (as well as lived) in more politically and economically marginalized spaces in the north.

This book focuses on the life history memories ${ }^{7}$ of Ciyaawo-speaking women mobilized to fight in Mozambique's independence war in the northwestern province of Niassa. These women were among FRELIMO's first female recruits. Many of them were under the age of fifteen when in 1965, FRELIMO started its military activities in their home areas. ${ }^{8}$ Some of them were already recruited by FRELIMO in 1965, though the formal integration of women into the guerrilla army occurred with the creation of FRELIMO's $\mathrm{DF}^{9}$ in 1966. In 1967, the first groups of girls were sent to FRELIMO's training camp in Nachingwea in southern Tanzania for political-military training (see Map 3.1 on page 100). It is my estimation that between 200 and 250 girls and women (approximately 10 percent of the total guerrilla force in Niassa) were integrated as soldiers into the Niassa front of the liberation struggle. ${ }^{10}$ At independence, while higher-ranking officers were transferred to the capital city and other urban areas, a majority of the rank-and-file soldiers returned to their rural origins. When I was conducting interviews in the capital, Maputo-which hosts a significant ex-combatant community-I came across only a few excombatants from Niassa; moreover, ex-combatants from Niassa (both Ciyaawo and Cinyanja speaking) were largely invisible in the public commemoration of the liberation struggle taking place in the capital city. This motivated my initial interest in conducting research in Niassa, which in Mozambican national imagery is often depicted as a peripheral hinterland, void of people and abundant in empty space. These landscapes, nevertheless, have been and are in continuous motion. The changing perceptions and conceptualizations of these landscapes are the focus of this book.

\section{Space, gender, and nationalist struggles}

This study has its theoretical beginning in the intersection of feminist scholarship on nationalism and spatial theorizing. Throughout the book, I seek to bring these two bodies of thought into conversation to explore what new 
insight a conceptual focus on space (or rather space-time) can bring to a feminist analysis of nationalism-more specifically, the particular historical formation and the spatiotemporal relationship between Frelimo nationalism and female ex-combatants in northern Mozambique. As feminist scholarship has already shown us, nationalisms are gendered; they are, Anne McClintock insists, built on "powerful constructions of gender difference." "Another central argument that underlies much feminist scholarship is that nationalism and masculinity are intimately connected. ${ }^{12}$ As expressed in the famous words of Cynthia Enloe, "nationalism typically has sprung from masculinized memory, masculinized humiliation and masculinized hope." 13 This study, however, seeks to problematize the assumption of their almost inseparable connection. As Thembisa Waetjen writing on Inkatha Zulu nationalism importantly argues, even though masculinity and nationalism seem to share a close relationship, the generalized assertions of this relationship can be problematic for research when research is used only to confirm that which is believed to be indisputable. ${ }^{14}$ Moreover, feminist analyses of nationalism often implicitly build on conceptualizations of space and gender that take the form of dichotomous dualisms: time versus space, and male versus female. In this analysis, the category of "woman" becomes symbolically fixed in unilinear historical narratives that privilege time and masculinity. Space that is conceptualized as feminine is defined as stasis and in binary opposition to masculine time. ${ }^{15}$ Thus while men are portrayed as the agents of national history, women and the feminine become symbolically inscribed in static notions of national space.

This type of theoretical framing is also evident in many studies on women's participation in the liberation movements in southern Africa. ${ }^{16}$ By focusing on making "women" visible as historical actors, their invaluable contribution has been to bring women's experiences and stories into history writing. Yet by looking mainly at women's roles (how women have been "used" in the nationalist struggles), they have tied "woman" to static spatial representations. ${ }^{17}$ In this study, I am interested in problematizing these notions of space and gender and thus disrupting some of the taken-for-granted assumptions that underpin studies of gender and nationalism. So far, not enough explicit attention has been paid to these analytical categories that nevertheless shape the histories we write. ${ }^{18}$ This is the analytical task to which my study seeks to contribute. I suggest that an analytical process that starts with less dichotomous conceptualizations of space and gender can contribute to a more multifaceted analysis of the gendered dynamics and processes of nationalist struggles.

\section{Space/place/landscape}

The concept of space that initially engaged me in this study draws from the theorizations of geographer Doreen Massey. ${ }^{19}$ As she demonstrates in her book For Space, in social sciences and philosophy, ${ }^{20}$ there has been a tendency to focus on time as the dimension of change and dynamism, while space has been conceptualized as a "flat surface" lacking movement. Space and time are thus 


\section{Introduction}

dichotomized; moreover, space is often devalued in relation to time. ${ }^{21}$ Massey insists that space be reconceptualized as space-time in which "space and time are co-implicated." This is important, she argues, for our understanding of politics; when we think of the spatial in terms of stasis, it constrains the sphere of the political and our possibility for action. As she writes, "Conceptualizing space as open, multiple and relational, unfinished and always becoming, is a prerequisite for history to be open and thus a prerequisite, too, for the possibility of politics." 22 For this reason, as I suggest, the conceptualization of space that informs studies of gender and nationalism is also of relevance. Massey proposes that we conceptualize space as "a simultaneity of stories so far." By using the term "story," she is referring not to a discursive dimension (of representations of the past), but to "the history, change, movement, of things themselves." 23 Moreover, as she argues, space does not stand in counterposition to place. They are not opposed to each other as the abstract versus the concrete, sensual, and intimate lived space. ${ }^{24}$ Space is equally concrete and material as place. Place is an event, a coming together of stories so far. As she explains, places are "temporary constellations where the repercussions of a multiplicity of histories have been woven together." ${ }^{25}$ Place does not have any pregiven identity; places are not bound or closed but open to interaction, and the relations that constitute a place "stretch beyond its boundaries." 26

Closely linked to the notions of space and place is also the concept of landscape. Similarly to space and place, landscape is conceptualized conjointly in both spatial and temporal terms. Massey offers an understanding of landscape as "the (temporary) product of a meeting up of trajectories." 27 This is opposed to the more dominant (Western) understanding of landscape in terms of visual representation, ${ }^{28}$ which implies the fixed relations of an immobile space. For Massey, "landscape" is, however, created in continuous movement. ${ }^{29}$ In her theorization, Massey argues against any easy separation of the concepts of space/ place/landscape. ${ }^{30}$ Space, as she argues, is the "founding conception" on which the other two rest. My conceptualization of landscape in this study combines Massey's theorization of space with a feminist phenomenological approach. This brings to my analytical focus the "lived experiences" 31 of landscape; moreover, the ways these experiences are shaped by gender and other modes of power. ${ }^{32}$ Phenomenology, importantly, allows us to move beyond thinking in terms of dualisms (e.g., discourse/materiality, mind/body, subject/object, and nature/culture). Landscape (the object) exists not in a dualistic relation to the subject; object and subject are intertwined. This is what is often referred to as embodied landscape. ${ }^{33}$ As Tim Ingold writes, "Through living in it, the landscape becomes a part of us, just as we are a part of it." ${ }^{34}$ Since we exist in landscape as "embodied beings," the boundaries between bodies and landscapes are not easily distinguishable. ${ }^{35}$ The body-landscape relationship is reciprocal; each is being made in relation to the other. The question is not merely about our relationship with the environment but also about the relationship that the environment has with us and how it interacts with our bodies. Moreover, embodiment needs to be understood through the notion of intercorporeality. ${ }^{36}$ This 
ties closely with Massey's understanding of landscape as the "meeting up of trajectories." Landscape is not only a coming together of human bodies and their social relations but also nonhuman actors, such as rocks, mountains, and rivers. ${ }^{37}$ Landscape is the inseparable intertwining of the physical, social, and cultural worlds. This idea of landscape converses closely with African perceptions of landscape, which often emphasize the intimate, reciprocal relationship between people and environment. ${ }^{38}$

\section{Politics of space}

Historians working on landscape perceptions in Africa have drawn attention to the different conflicting ways that the nineteenth-century European colonizers and local peoples perceived and described the landscape. What the colonizers perceived as an empty landscape was for the local peoples imbued with long histories of human and beyond human encounters. For instance, Terence Ranger has looked at how these different perceptions and understandings of landscape continued to coexist and interact throughout the colonial period. ${ }^{39}$ In his study on the Matopos Hills in Zimbabwe, Ranger shows that despite the colonizers attempt to write their history into the landscape, local people held on to the sacral meanings that the hills had for them. Thus the different meanings of this landscape were strongly contested throughout the colonial period and no meaning or political force fully dominated. In this sense, he argues that the colonial conquest of the Matopos was never complete. This, according to him, is also attested to by the thousands of pilgrims who after independence continued to visit the cave shrines of the Mwali cult at the Matopos Hills. Historian Allen M. Howard emphasizes further the evolving histories and changing meanings of such religious centers over longer historical periods. ${ }^{40}$ Howard focuses on the "great space-shaping forces" (e.g., the spread of Islam, the slave trade, wars) that over several centuries transformed the African landscapes. From this perspective, one can see the histories and meanings of regional political and religious centers evolving through cycles of rise and decline. For me, these studies importantly speak of the different spatial discourses that have in complex ways shaped ideas and perceptions of African landscapes.

As already mentioned, this study focuses on the nationalist struggle as a "particular historical moment of contestation and change" 41 in people's landscape perceptions in northern Mozambique. I look at the ways that the new nationalist discourse effected people's sense of landscape and spatial belonging. My focus is not on how language makes space ${ }^{42}$ but on the co-constitution of conceptual and lived space. The neo-Marxist philosopher Henri Lefebvre offers some useful analytical tools for this. Similarly, to Massey, his theorization builds on the conceptualization of space and time as co-constitutive of each other. Here, I am especially interested in Lefebvre's "conceptual triad," which he develops in The Production of Space. As he suggests, the production of space can be understood as a dialectical spatial triad constituted by "spatial practice" (perceived space), "representations of space" (conceived space), and "representational spaces" 


\section{Introduction}

(lived space). "Representations of space" concerns space as it is conceived of by governments, scientists, and others claiming expert knowledge. This is the symbolic space produced in discourse, programs, maps, etc. According to Lefebvre, it is the "dominant space in any society." ${ }^{43}$ It pertains to the ideological production of space. Spatial practice refers to the unreflected, material way that space is made through the everyday movement, communication, and activities of the people; it is space as sensuously perceived by people. ${ }^{44}$ Spaces of representation, the third dimension of the production of space, concerns the space that emerges from a relation between spatial practice and representations of space; it is the lived and imagined space of the people. This space is always constituted through struggle. ${ }^{45}$ Lefebvre's spatial triad closely links with my idea of the lived landscape. ${ }^{46}$ In my study, I seek to explore how the ex-combatants' landscape experiences are shaped through their sensory, bodily engagement with landscape as well as in relation to the different shifting and competing spatial discourses that seek to impose their definitions over the landscape.

\section{Gendered bodies}

This book importantly places the lived gendered body at the center of analysis of the liberation struggle. The ex-combatants' emphasis on bodily experience in their narratives initially motivated this approach. In my conceptualization of the gendered body, I draw both on Judith Butler's notion of gender performativity and the theorization of feminist phenomenologists of embodiment, most notably Sara Heinämaa, Gail Weiss, and Lisa Folkmarson Käll. Though Butler's radical social constructivism and phenomenology of embodiment have their points of contestation (see also page 83) ${ }^{47}$ I suggest that reading them together can allow us to better explore the intersections between discourse and material practices of the body. ${ }^{48}$ Both Butler and the feminist phenomenologists acknowledge that gender is not an essential identity, a natural fact. ${ }^{49}$ Butler argues that the gendered body does not exist prior to its cultural constitution. As she writes, "There is no gender identity behind the expressions of gender; that identity is performatively constituted by the very 'expressions' that are said to be its results." ${ }^{50}$ This does not, however, imply that one is free to choose how to do one's gender. Rather, gender (and sex) are "punitively regulated cultural fictions." ${ }^{1}$ While for Butler the gendered body is essentially a "discursive effect," ${ }^{2}$ the feminist phenomenologists emphasize the intertwining of the material and the discursive in the body's constitution. ${ }^{53}$ The lived body, as Käll writes, is "situated and embedded in a surrounding world, with which it is engaged in an ongoing dialogue." ${ }^{54}$ Even here the body does not escape the productive and disciplinary forces of gender ideology. Since the body is always born into a specific spatiotemporal situation, it is the "carrier of meanings that go beyond any individual intention or creation." ${ }^{5}$ Yet these external meanings, she argues, do not determine the embodied selfhood; rather, these meanings become altered "as they are lived out in singular embodiment." 56 Moreover, as Sara Heinämaa explicates, "The values and meanings that are crucial here are not the ones forced on us by 
others - the society - but those that we realize in our actions. They are not external to the body, but its own (re)creations." ${ }^{57}$ Both Butler and Heinämaa argue in surprisingly similar language that gender is maintained by repetition, and this repetition always carries the possibility of subversion, a doing differently. Yet it would seem that while Butler's theorization emphasizes the powerful external regulation of cultural scripts and the "punitive consequences" 58 of the failure to do one's gender correctly, the feminist phenomenologists assert the creative agency of the body.

Through the chapters of this book, my own conceptualization of the body balances between a social constructivist and a phenomenological position. In Part I, I focus on the discursive and ideological construction of the body. I look at how the FRELIMO nationalist discourse created space for new ways of conceptualizing and living gendered bodies. At the same time, I also interrogate the relationship between body and discourse and explore how individuals creatively negotiate the meanings imposed on them from the outside. In Parts II and III, I shift my analytical focus to the phenomenological body and its lived relationship with the world. While throughout the study, I continue to also draw from Butlerian social constructivism and the idea of the body as a site of power, disciplinary practices, and resistance; the notion of the "lived body" aligns me closely with feminist phenomenology of embodiment. I especially find Sara Heinämaa's proposal to understand femininity and masculinity, as well as manhood and womanhood, as "styles of being" a fruitful way of analyzing how the female ex-combatants I interviewed perceive their gendered bodies and their relation to the world. Heinämaa insists that the question that matters when describing gender is not "what we are" but "how we are." 59 She calls for gender to be understood as a weft of dynamically connected attributes, elements, and bodily acts. Moreover, I suggest that analyzing gender in this way can also allow us to address some of the criticism that African feminist scholars have deservedly directed at Western gender scholarship. African gender scholars such as Oyèrónké Oyěwùmí and Ifi Amadiume have criticized non-African feminist scholars for examining African realities through Western gender categories, especially the male/female dichotomy and its "male gender privilege." Ifi Amadiume argues that in the rigid framework of the Western two-gender system, roles are strictly masculinized or feminized, and thus a woman taking on a role conceived of as masculine becomes reclassified as "manlike." assuming the universality of the category of "woman," Oyĕwùmí, moreover, insists that distortions are produced and local experiences effectively silenced. ${ }^{62}$ The challenge she poses is to leave the content of "woman" open, to allow for its definitions to arise from other cultural and historical contexts, not fixed to the researcher's own experience. This connects closely with the phenomenological approach of "putting the world in brackets" (or the "phenomenological epoché"), ${ }^{63}$ which entails that we critically confront our taken-for-granted assumptions so that we can better study the world and the complexity with which it manifests itself. ${ }^{64}$ This also involves acknowledging that the "complexity of women's lived experience" is necessarily constituted through multiple intersecting identity categories (e.g., age, class, gender, and ethnicity). ${ }^{65}$ 


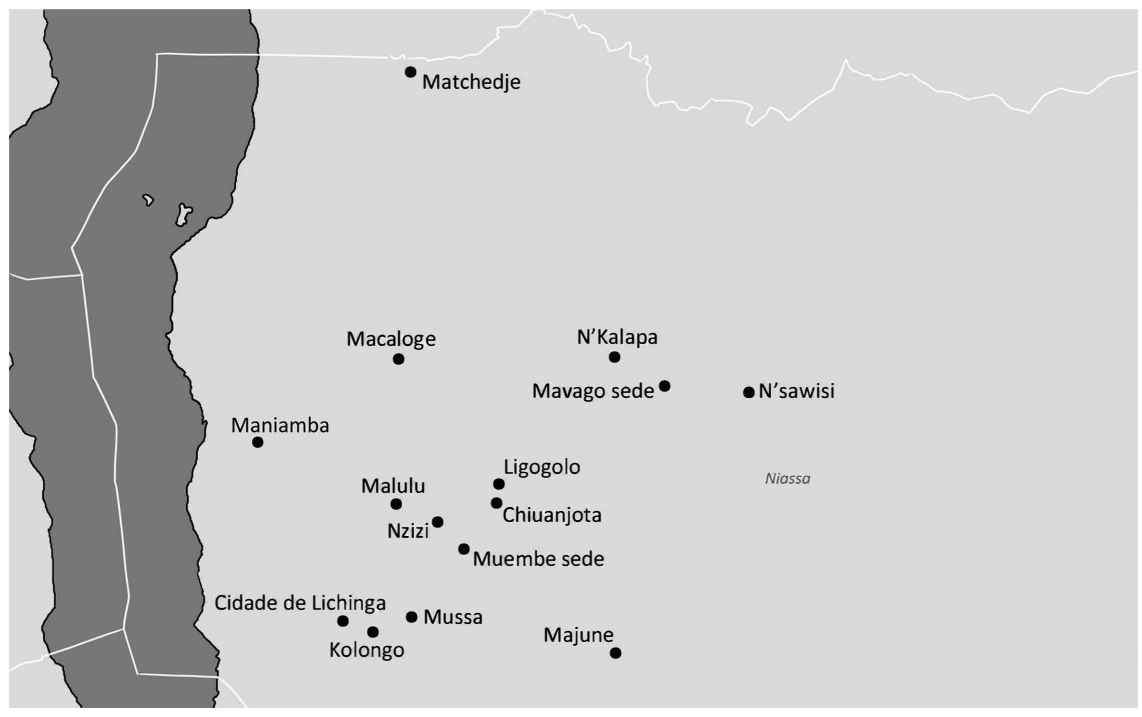

Map 0.1a Research sites in Niassa

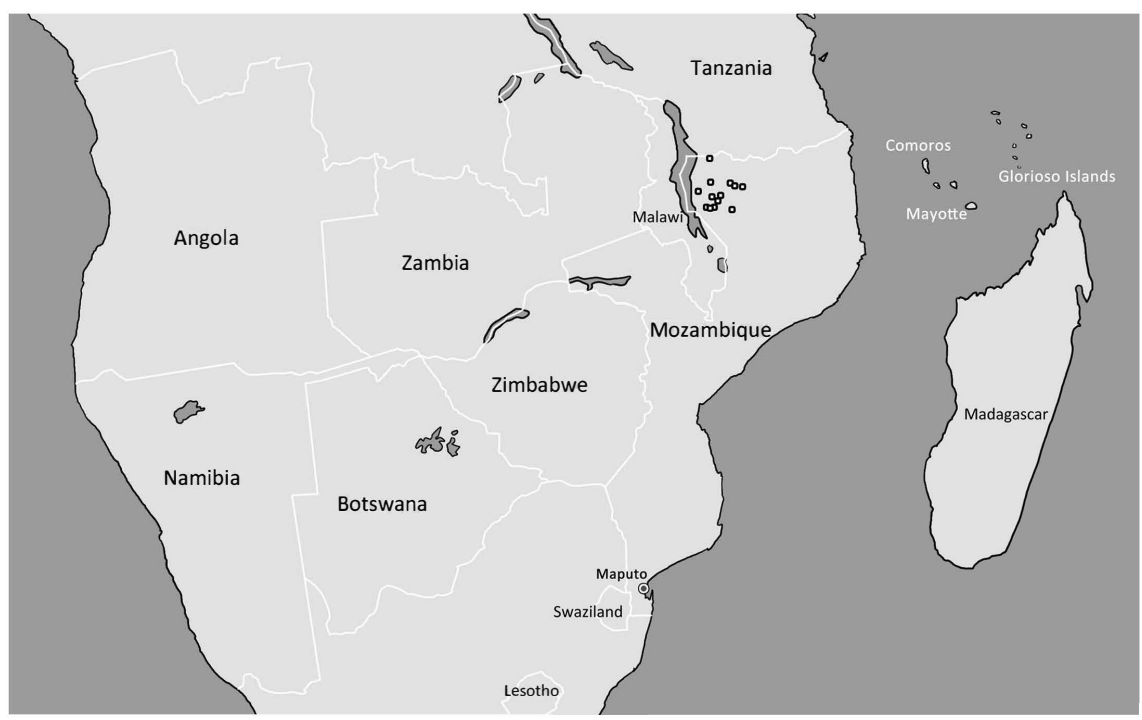

Map $0.1 b$ Research site (marked with white circles on the map) in relation to the larger geographic space of southern Africa

Source: Maps by Mikko Kankaanpää 


\section{Researching lived landscapes}

This study mainly builds on fieldwork conducted during twelve months in northern Niassa between 2012 and 2014. Initially, I had planned to stay in one smaller location for the whole extension of my fieldwork, but after starting my research, I soon I discovered that this made little sense as apart from a larger concentration of ex-combatants in the provincial capital Lichinga, where many had moved after independence, the DFs were dispersed in small numbers across the various districts of Niassa. As a consequence, my fieldwork became multisited, and I elected to include a relatively high number of localities in my study. Choosing, moreover, to focus on the Ciyaawo-speaking ex-combatant population $^{66}$ defined my research site to the area stretching from Lichinga to the Tanzanian border in the north and extending toward, though not quite reaching, Lake Niassa in the west (see Maps $0.1 \mathrm{a}$ and $0.1 \mathrm{~b}$ on page 10) ${ }^{67}$ Logistically, it then made sense to have my base in Lichinga, which as the provincial capital is the transport hub of northern Niassa, and from there, I could relatively easily organize my travels to the different districts.

Expanding my research to cover more districts also made sense as I learned that most DFs have led quite mobile lives, and multiple places across this region have formed their life trajectories and historical memories. Movement and mobility thus became an integral part of my analysis as well as my research strategy. I gained a lot of knowledge about the landscape of Niassa traveling its dirt/mud roads in run-down, overpacked chapas (or minivan transport) and sometimes motorbikes and trekking by foot along winding machamba paths or the dirt roads of Lichinga. And so my research was informed not only by the interviews but also by my own movement with my travel companions through the different locales of northern Niassa. I also spent numerous hours outside the recorded interview situations with the DFs getting to know their living environments in their villages and machambas. Many stories about wartime movement were also told during these walks. As Jo Lee and Tim Ingold argue, this kind of "shared bodily engagement with the environment" (they refer especially to walking) — rather than the typical face-to-face interview — creates a sense of physical copresence that also contributes to social bonding. ${ }^{68}$ By becoming mobile with my research participants (not only by walking but also traveling by chapa), I was able to gain more understanding about the connections between the different locales, how places interact and are shaped through people's real and imagined movement, and how these moving spatial relations can be studied as landscapes.

\section{Research relationships and recruitment of interviewees}

My understanding of these landscapes was, moreover, crucially shaped through the different social relationships of my research. Throughout my fieldwork, I worked especially closely with a DF called Helena Baide, whom I first met at the Association of the Former Combatants of the Liberation Struggle (ACLLN).$^{69}$ ACLLN is an important gatekeeper to the ex-combatant community in Niassa (see also the introduction to Part II), and upon my arrival, I had to go through them to negotiate initial access. ${ }^{70}$ In the very beginning, the male ACLLN officers even 


\section{Introduction}

sought to arrange interviews for me. Yet these attempts were largely unsuccessful, and the only DF to respond to their call was Helena. She first became a research participant in the project, but later as we got to know each other, she also assumed the role of co-interviewer in my interviews in Ciyaawo. Although recruitment of interviewees was slow in the beginning, it picked up pace as I teamed up with Helena, who from the beginning was very enthusiastic about my plan to write about the life histories and present-day experiences of DFs in Niassa. Together, we took on foot to the different bairros of Lichinga, and by chapa to the rural villages of northern Niassa, to locate female ex-combatants and to talk to them about their lives and experiences in the guerrilla army.

Throughout the fieldwork, Helena played an essential role as a linguistic and cultural translator; also, by sharing the same background as our interviewees and knowing many of them personally, she helped me to negotiate access and build trust within the DF community. Moreover, the way Helena positioned me when introducing me played an important role in how I was accepted. She liked to emphasize that I had come from "far way" just to write about the DFs. Her words evoked positive reactions from most DFs. As some of them expressed, the fact that someone had come looking for them meant that what they had done during the war continued to matter. During my fieldwork, I formed closer relationships with some of these women, while others remained more distant. Overall, I tried to be responsive to and respectful of the boundaries that the women set and mindful of our age differences. Also importantly, while we socialized outside the interview situations, the interviews themselves were not framed as informal conversations. Rather, the women often talked of "getting to work" when starting an interview.

Always before starting to work with a new person, Helena and I first explained the purpose of the research project, its voluntary nature, and the idea of the life history interviews. ${ }^{71}$ Moreover, even though I always negotiated consent with my research participants at the onset of the research process, through the fieldwork, I came to understand informed consent as an ongoing process that involves continuous (re)negotiation. ${ }^{72}$ Throughout our interaction with the DFs, we thus tried to encourage them to ask questions if they had any doubts about their participation in the project. Our interviewing was also organized so that we had longer breaks (from several weeks to months) between the interviews, which gave the women more time to think things through. On our last trip in 2014, we visited all our research participants one final time and asked them if they had any second thoughts about the interviews and whether there was anything that they wanted to take back or add. Usually, if they wanted to add something, they lamented on the suffering of the ex-combatant population in Niassa. It was clear that one of the ways that the ex-combatants sought to use the interview to their own advantage was to voice their dissatisfaction with the government.

\section{Interviewing}

A majority of the interviews were conducted in Ciyaawo with Helena translating both my questions and the women's answers. ${ }^{73}$ Prior to the start of my 
fieldwork in Niassa, I had also prepared an interview guide in Ciyaawo with the help of my language assistant Bernardo Aubi Silajo. This helped me to acquaint myself with the relevant language, though in the end, Helena's translations were quite different. Drawing on her experiences as a DF, she was able to reformulate the questions in a language more understandable for the women. In some sense, I lost control of the questions when Helena translated them. This forced me to share authority with her in the interview situations. Sometimes I found this frustrating and urged her not to take liberties with the translations. Yet many times, her creative reformulations of my interview questions gave me new insight and introduced new avenues of inquiry. My research material would have looked very different without her involvement, and it was our collaboration that produced the material that is the subject of this book. Throughout my fieldwork, I also worked very closely with Bernardo, who invaluably contributed to the research process by transcribing the audio recordings of the interviews and working with me on the translations.

Altogether, I conducted life history interviews with thirty-four female excombatants whom I interviewed at least three times each. ${ }^{74}$ These interviews were mostly conducted during the first phase (November 2012-September 2013) of my fieldwork. Most of the interviews lasted one to two hours. Usually, we sought quiet places where we could sit and talk without disturbances. Sometimes we sat outside in the women's yards, other times inside their houses, and on other occasions we sought the peace and quiet of their machambas, away from curious neighbors and the noise of grandchildren. The first of the three interviews that we conducted focused on memories of childhood and the homeplace before the war. This interview was also designed to help build rapport and in a gentle way introduce the women to the idea of the "life history interview" and the type of questions it entailed. This was important because the topic of the second interview was more sensitive, dealing with the women's memories of their experiences of the liberation struggle. The third and last life history interview focused on the experience of life and the sense of homeplace in the postindependence period.

The interviews with DFs were furthermore augmented by small group interviews (two to three per group) with thirteen male ex-combatants altogether. ${ }^{75}$ I expected that it would be easier to reach male ex-combatants because many more men participated in the liberation struggle than women. However, since male ex-combatants are generally older than the female ex-combatants, many of them have already passed away. The group interviews with men lasted three to two hours each. The men were given turns to speak about their lives and home spaces before the war, life and work during the war, and their experiences of life these days. I also asked a few questions relating to their experiences of working with DFs during the war and their memories of FRELIMO's gender discourse. In addition to interviews with DFs and male ex-combatants, I conducted interviews with community elders about the older historical memories of the region. From these elders, I heard stories about the time before the Portuguese colonial presence: old wars (the Ayaawo ${ }^{76}$ with the Angoni, Yaawo chiefs with each other, people with lions, etc.), the old régulos (chiefs), and the arrival of the first whites in the area: the English missionaries, the Germans, 
and, finally, the Portuguese occupation of Niassa. I also asked some of these elders to speak about their own life histories.

My final fieldwork was conducted over a period of two months (MayJune 2014). I set out with the objective of deepening my understanding of the relationship between the body, the senses, and (violent) memories. This was a theme that had come forth in the life history interview material. In addition to small conversational meetings with all of the thirty-four women ex-combatants that I had conducted life history interviews with during my previous fieldwork period, I conducted further in-depth interviews with ten of them. These women were selected based on my rapport with them in the previous interviews as well as their willingness and availability to participate in further interviews. This time, my interview guide focused on eliciting talk about "body experience": e.g., the memories of the young soldier body, the experience of the aging body, the experience of the veteran's body, and the lingering memories of war on the body. It was possible to discuss these sensitive topics largely because of the mediating role that Helena played in assisting me in the interviews conducted in Ciyaawo. The final interview questions were formulated with her in the interview situations. In the beginning, I was concerned about whether my questions might sound alien or insensitive to the women. However, I discovered that some of the questions that I thought could be more sensitive, turned out to be commonsensical. Some women even expressed surprise that I had not asked these "important questions" already during previous interviews. During my final fieldwork stay, I also visited some of FRELIMO's more important wartime military bases in Niassa and conducted walking interviews on the history and general organization of the bases during the war with some of the women ex-combatants who had lived and worked at these bases. In addition to this, to gain a better understanding of the "event history" of the liberations struggle on the Niassa war front, I interviewed some higher ranking male ex-combatants both in the capital Maputo and in Niassa. I also interviewed representatives of ACLLN in the various districts and in the provincial capital Lichinga, as well as representatives of the Ministry of Combatants in Lichinga and in Maputo, to deepen my understanding of the general situation of ex-combatants in the country.

Overall, many women expressed pleasure in having the opportunity to reflect upon their past life experiences. Mindful that the interview could bring forth negative feelings and painful memories, I avoided confrontational questions; instead, I favored more open-ended questioning that allowed the women more narrative control. Also, nonverbal communication played a crucial role in the interviews. I sought to be attentive to the body language of our interviewees and respectful of their emotional boundaries. ${ }^{77}$ Helena was crucial in helping me navigate these boundaries and find the right sensitive language to ask about more difficult topics. ${ }^{78}$ She helped create a supportive atmosphere in the interview situations in which humor and shared laughter also played an important role. ${ }^{79}$ Sometimes Helena would tell funny stories about her own experiences to relieve the tension and make people laugh. We usually ended 
the interviews by asking for more affirmative stories. After each interview, I also asked if the interviewees had anything more that they wanted to add or if they had something they wanted to comment on. The interviews were conducted with the help of a semistructured interview guide, which I continued to develop throughout the fieldwork. The women responded in individual ways to the questions. Some interviewees chose to keep their answers short and not delve too deeply into their memories. Others offered more detailed self-reflexive, analytical, and contemplative responses. The interview situation, as I understand from a feminist standpoint, is a power-laden interactive situation of both-way negotiation. ${ }^{80}$ The women I interviewed also spoke through silence, refusal to answer, questioning the validity of my questions, and changing the topic and even their stories. Knowledge is, after all, always unfinished, situated in a dialogical moment of questioning, challenging, and responding.

\section{Politics of naming}

Often, as a rule in research on ex-combatants, the practice is to anonymize research participants. Their identities are disguised for the purpose of protecting confidentiality. For my research participants, however, naming was an important part of telling their life stories. Part of their motivation to share their stories was a desire to have their names included in a written historical record. After all, this would ensure that they would be remembered by future generations. Through my research, I thus came to understand that for many of my interviewees, naming was an important political act.

In qualitative research ethics, the idea of "protecting" our research participants by anonymizing them still overwhelmingly dominates. ${ }^{81}$ The reasoning often follows the line that neither the researcher nor the researched can fully know the ramifications that the research might have. Still, I argue that even a well-meaning feminist ethics of care risks having patronizing and disempowering effects when it builds on the assumption that certain (according to our definition) vulnerable people cannot possibly know what is best for them. ${ }^{82}$ In my research, I decided that it would be unethical not to name my research participants. If they felt comfortable and secure telling their life histories in their own names, who was I to argue against. By going against their wishes to be named, I would be patronizing them and undermining their capacity and right to speak for themselves. As Katja M. Guenther argues, "Confidentiality serves not only to protect, but also to injure." ${ }^{83}$ As discussed in the previous section, the interviewees had control over which kind of stories they told about their lives and how they represented themselves to me. By hiding their identities, I would be denying them that sense of agency and ownership. My interviewees were not asking for secrecy, but they wanted some of their experiences made public for people to become aware of their histories and current struggles. After all, they had their own ideas of how to use their participation in my research to their benefit. In my previous research among female ex-combatants in Maputo between 2008 and 2009, my research participants had expressed the wish that 
their real names be used, but because of my own discomfort, I made the decision to use pseudonyms instead. Afterward, I received complaints about this, and my interviewees urged me to change these pseudonyms back to their real names. These women clearly did not want my "protection." For them, identifying themselves was an integral part of the political act of speaking and making their voices heard. And thus by one-sidedly deciding to "protect" by anonymizing, I was effectively silencing their voices.

Naming, moreover, forces the researcher to assume more accountability for the ways that she represents her research participants. Nancy Schepher-Hughes argues very critically that "[a]nonymity makes us unmindful that we owe our anthropological subjects the same degree of courtesy, empathy and friendship in writing as we generally extend to them face to face in the field." ${ }^{4}$ In writing up our research, we always make choices over what to include and what to leave out. In my case, I sometimes chose to write more generally when discussing more sensitive topics and thus not to identify anyone in particular. I also keep clear of discussing or calling into question anyone's self-identification as ex-combatant.

\section{Transcription, translation, and the ethics of representation}

All the interviews were recorded, and many were also filmed. The audio recordings of the interviews were transcribed according to a "strict verbatim" protocol, which means that every utterance (even false starts and the uhm's and ah's), pause, and other sounds, such as laughter, were transformed into written text (see page 258 for transcription symbols). ${ }^{85}$ For me, the benefit of verbatim transcription is that it allows a more detailed look into the interactional aspects of the interview conversations. Verbatim transcription also shows the rhythmicity of the interview and better captures the individual style of the narrators. Thus in my analysis, I was able to be more attentive to the subtleties and nuances of speech and interaction, which helped me more closely to examine the meaning-making processes of the interview situations. Moreover, as in this study, I am also interested in speech as a bodily performance-together with words, the bodily features of speech, such as tone, pitch, and amplitude of voice, and the accompanying bodily gestures form part of the talk-in-interaction that I analyze.

In this book (due to limitations of space), I mainly present the English translations of the interview excerpts. ${ }^{86}$ In these translations, I have sought to balance between staying true to the verbatim transcription and making sure that the speakers' intended meaning is not lost. Translation is a process; it is always partial and always involves cultural interpretation. Overall, my research involved various parallel and intertwining translation processes. In the interviews, Helena translated the women's speech to me (Ciyaawo to Portuguese) and my speech to the women (Portuguese to Ciyaawo). Then with Bernardo, we worked on more word-to-word translations of both Helena's and the DFs' speech (Ciyaawo to Portuguese). In the end, my English translations are based on this translation 
work with Bernardo and the discussions we had on the different meanings and interpretations. The excerpts that are presented in the final text were further revised and discussed with two other language assistants (Fátima Alberto Camoto and Manuel Sairesse Chicote) in Lichinga in April 2016.

I have chosen to include extended interview excerpts in this book in order to bring to the forefront the processes and interactional situations in which meanings are negotiated and knowledge is produced. ${ }^{87}$ The text also aims to privilege the women's voices. By giving more space to the women's words, the text, moreover, allows the readers the possibility to make other interpretations alongside those of the author. This ties closely with my understanding of ethical representation, which builds on a feminist epistemology that stresses the partiality and situatedness of all knowledge claims. ${ }^{88}$ This also means that representation can never be assumed to be innocent, for it is always tied to the production of knowledge and power. Research into life histories can never be about capturing "authentic voices." 89 Even in the most collaborative research, the final author of a study is always the researcher, who decides how to frame the voices of the research participants. ${ }^{90}$ Thus she is ethically accountable and responsible for those representations. Chandra Talpade Mohanty has famously and very forcefully criticized "western" feminist scholarship for reproducing "ethnocentric universalism" in their representations of "third world women." ${ }^{11}$ She argues that this is a form of epistemic colonization that involves the "suppressionoften violent — of the heterogeneity of the subject(s) in question." ${ }^{\prime 2}$ In my study, I have sought to represent my research participants in a way that does not fix, stabilize, or essentialize them. Rather, I have tried to emphasize the movement of their identity negotiations. While I also look at the ways that our subjectivities are produced by powerful and often violent discourses, still, I emphasize our bodily creativity in these processes. This has led me to privilege the nuanced complexities of lived experience as well as the ongoing negotiations to narrate our lives and our selfs. The narratives that I discuss are not the only possible stories about the women's lives; they are stories that the women elected to tell in the interview situations. This study, moreover, seeks to "evoke space/place/ landscape as alive with temporalities" 93 open for reinterpretation and not an already determined history. The next subchapter takes us deeper into the moving landscapes of Niassa to situate the women ex-combatants' life narratives within its spatial histories.

\section{Historical landscapes of "Niassa"}

So in the old days the Yaos were great travellers, for they used to say, "He who knows foreign parts is a man worth knowing, like so-and-so's son." Even in the village "place" the great subject of conversation was travel, and he who knew other countries was always listened to with respect, the people hanging on his words delighted, all of them gazing at him, sometimes with awe, saying, "Good lord! you are a wonder! Eh! but you have travelled!" And the people would believe anything he told them. A man who had not travelled and seen other countries, though, could not take any part in the conversation in the "place"; he would sit there without saying 
a word, while everybody laughed at him, "This fellow's name is 'stay-at-home,' who always remains in the village, not a single foreign country does he know." Everybody would regard him as a fool; anything he might say the people would contradict, "No, what country does this fellow know? It's a lie, he's only a pounder of grain.”

That is why we Yaos sing:-

"Goodbye, goodbye,

Goodbye you pounders of beans." 94

The previous text evokes an idea of the gendered mobile landscapes that now constitute the area known as Niassa in northern Mozambique. Yohanna B. Abdallah wrote this descriptive account at the turn of the twentieth century. It constitutes part of his study Chiikala cha Wayao (or The Yaos), one of the first written histories of the Yaawo people. Abdallah was himself a Yaawo who was brought up in southern Tanzania in the 1880s. He wrote his study while he was working as a priest at the Anglican mission in Unango (close to the village of Malulu in what is now the district of Sanga). In the preface to the book, Abdallah explains that he is writing for a Yaawo audience. As he argues, he wants the Ayaawo to be reminded of their own history as a people. The first part of his study focuses on the culture and social practices of the Ayaawo. The historical part centers on the evolvement of the coast trade, the upheavals and migration caused by famine and Ngoni attacks, and the rise of the powerful Yaawo chieftaincies in the mid-1850s. His study is considered a major source on the political organization and population movements of the Ayaawo inhabiting what is now known as Niassa prior to Portuguese colonization of the area. In this subchapter my focus is on the historical construction of "Niassa." My aim is to give an idea of some of the longer histories and spatial movements that have shaped its landscapes. I start by looking at the period prior to the colonial construction of Mozambique and Niassa. My focus is especially on the movements and migrations and oral history of the Yaawo people.

\section{Long-distance trade}

There are only scant details of Yaawo history prior to the nineteenth century. The main sources of the earliest period are mostly travel accounts by European explorers. They give us little information of Yaawo political or social organization, but they give some idea of the development of the Yaawo trade networks. Based on Portuguese sources, Manuel Gama Amaral argues that it is probable that the Ayaawo were already in contact with the Arabs at Kilwa on the coast of the Indian Ocean in present-day Tanzania well before the arrival of the Portuguese in the sixteenth century (see Map 0.2 on page 19). ${ }^{95}$ Other historians have been more cautious in their estimations. Alpers writes that the account by Brazilian-Portuguese trader Gaspar Bacarro of his travel from Tete to Kilwa suggests that the Ayaawo had well-established trade networks with the coast by the beginning of the seventeenth century. ${ }^{96}$ However, Alan Thorold argues 


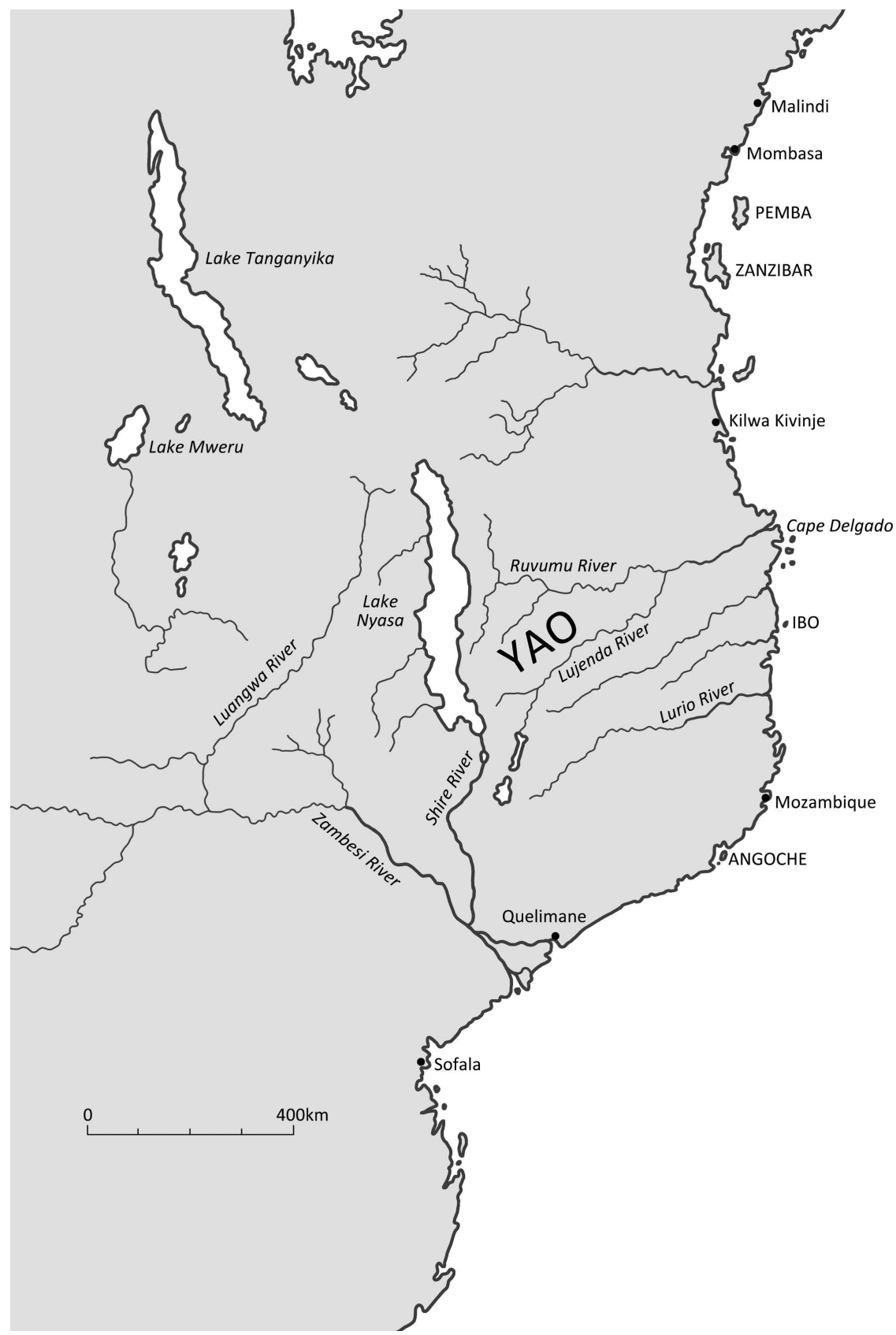

Map 0.2 The East African region

Source: Edward A. Alpers, Ivory and Slaves: Changing Pattern of International Trade in East Central Africa to the Later Nineteenth Century, (C) 1975 by the Regents of the University of California. Published by the University of California Press. Map redrawn by Noora Katto. Some place names in the original map have been left out 
that since Bacarro does not mention the Ayaawo by name, another group and not the Ayaawo might have been operating this trade. ${ }^{97} \mathrm{He}$ argues that the earliest documented evidence of the Ayaawo being involved in long-distance trade comes from the eighteenth century. ${ }^{98}$ Though no one knows exactly when and how the Ayaawo got involved in this long-distance trade, these trade networks must have developed and expanded over a longer period of time. ${ }^{99}$ In the beginning, local products such as tobacco, hoes, and animal skins were exchanged for salt, cloth, and beads at the coast. ${ }^{100}$ Later, the Ayaawo shifted to the ivory trade, which became increasingly important in the eighteenth century. The Ayaawo were the middle men in this interaction, and they relied on suppliers further in the interior who provided them with ivory that they then traded on the markets of Kilwa and Mozambique Island on the coast of the Indian Ocean. ${ }^{101}$ By the eighteenth century, the Ayaawo had gained command of the ivory trade in the area north of the Zambesi River, and by the mideighteenth century, they had reached into Luangwa in present-day Zambia and also expanded their networks south of the Zambesi (see Map 0.2 on page 19). ${ }^{102}$ At the time, the Yaawo trade caravans were significant in size; according to Newitt, some had even as many as 1,000 porters. ${ }^{103}$

\section{Chiefs and political power in the nineteenth century}

By the second half of the nineteenth century, both the Nyanja and Ayaawo living in the area of Niassa were divided into small states. ${ }^{104}$ These ethnically diverse states were held together by political alliances. ${ }^{105}$ They were headed by territorial chiefs who governed over subchiefs and their constituents. The states had no formal territorial administration. The village headman was responsible for the local government and had relative autonomy to manage the daily affairs of the village. ${ }^{106}$ As political alliances kept shifting, the states constituted relatively unstable political units. For instance, a headman could withdraw his support from one chief and pledge his alliance to another. ${ }^{107}$ According to Liesegang, the traditional taxation system before the colonial era was based on the idea of reciprocity. ${ }^{108}$ Taxes were not formally enforced, and they did not have a fixed sum. They were offered as a way of thanking the chief for the good social order and the favorable agricultural production of the year. Moreover, as Liesegang explains, tribute was paid on two levels: first, "chaculamba" was offered to those belonging to the same social class, for instance, from one chief to another chief to seal a friendship or peace pact; the second, "chamoto" was paid to the chief by his subjects. ${ }^{109}$ "Chamoto" was paid to the chief due to his position as the "owner of the fire" as the term indicates. ${ }^{110}$ His subjects would, for instance, present him with a portion of the kill from a hunting expedition or fishing trip, or a share of the products they traded on the coast. ${ }^{111}$

Increased long-distance trade (especially in slaves) importantly shaped the Yaawo political organization. It contributed to the prestige of the chiefs who controlled the trade and allowed them to expand their states. ${ }^{112}$ As the Yaawo have a matrilineal kinship system-meaning that descent is traced through 
maternal lines - the leaders of the caravans were often nephews of the chief and thus potential heirs to his chieftaincy. ${ }^{113}$ These men belonged to the most privileged segment of the population, the aristocracy, and held important leadership roles in political and economic matters. ${ }^{114}$ As a man's social position depended not only on his position in the matriliny but also on the number of people under his control, the lineage heads and chiefs augmented their power by incorporating slaves into their family units. Slaves constituted a significant percentage of the population. These slaves had different origins: some had been enslaved for the crimes that they had committed; others had been bought; yet others had been captured during raids. Though they constituted the lowest class in society (and had to, for instance, dress differently from free men and the aristocracy), it is probable that they lived relatively ordinary lives in the villages. ${ }^{115}$ Male and female captives were, according to Alpers, treated differently: while men were often sold, women were assimilated. ${ }^{116}$ According to matrilineal practices, children belong to the mother's lineage, but the children born by these women far removed from their families belonged to the husband's decent group. This contributed directly to the strengthening of the husband's lineage. ${ }^{117}$

The role of women in the precolonial political structures has received little attention by historians. Yet there is evidence that the Ayaawo have had a tradition of female chiefs (Ciyaawo: mwenye wakongwe), later known as queens (Ciyaawo: bibi; Portuguese: rainha). For instance, Abdallah starts his history on the rise of the Mataka dynasty in these words:

In the Yao country at Likopolwe a woman was born whose name was Che Syunguli, and she bore many children both male and female, and many grandchildren, and she became Queen [Ciyaawo: mwenye wakongwe] like Achuma-cha-Mlungu and Che Kambutu. Her fame spread everywhere as a powerful and fully recognized chief, and a successful.

So it came about that one of her grandchildren named Che Nyambi, the son of Kunakawale, became dissatisfied and said, "Seeing that this country is filled with the fame of a woman, I and my younger brothers will go and settle elsewhere." Therefore Che Nyambi left the Hill Yao with his mother Kunakawale, his aunt Kwikanga (sister of Kunakawale) and her son Kumtelela. At Likopolwe he left Che Ujenao (the younger sister of Kunakawale) and the mother of Che Mtamila of Likopolwe, and his cousin Kung'ombo. ${ }^{118}$

This passage speaks of the significant political power that some women exercised in precolonial times. Yet, according to Liesegang, these female chiefs no longer appear in sources from the second half of the nineteenth century. ${ }^{119}$ By the colonial period, women's political roles had changed. Liesegang questions whether this might be a result of political transformation or the ideological impact of Islam. ${ }^{120}$ Accounts from the turn of the twentieth century speak of the political and ceremonial role of the sister (or maternal aunt) of the chief. The sister of the chief played an important role in the ancestral cult. In the communal 
ceremony known as mbopesi, which is performed at least once a year, the chief and his sister make a sacred offering of maize flour at their ancestors' grave or at the nsolo spirit tree, calling on the spirits of their ancestors and through them to God to protect and defend their population from wild animals and illness, and to grant them rain and favorable weather conditions for their crops to yield well. ${ }^{121}$ These days, the chief's sister holds the title bibi (Portuguese: rainha). One might understand her role today as part of a double-gendered system of chieftaincy. While the matrilineal male chief or mwenye (Portuguese: régulo) holds the most powerful position, ${ }^{122}$ the chief of the women, bibi, plays a crucial and important complementary role. In addition to her role of mediating with the spiritual world, she also arbitrates social issues and disputes that arise between women and receives the most important guests of the chief. ${ }^{123}$

\section{Wars and mass migrations}

The nineteenth century was a period of upheaval, as the Ayaawo and Nyanja suffered military attacks by the Ngoni and Makhuwa groups that caused mass migrations of the population to the area now known as southern Malawi. Between around 1831 and 1845, the Ayaawo and Nyanja were raided by the Lolo, or Makhuwa-Lomwe, people. ${ }^{124}$ These attacks were still part of oral history when Abdallah was writing his study. Abdallah suggests that internal conflict among the Makhuwa caused by famine led the defeated group to attack the Ayaawo. ${ }^{125}$ The pressures caused by Arab slave trading has also been suggested as a reason for the violent and intrusive movement of the Makhuwa into Yaawo country. ${ }^{126}$ These attacks in turn led thousands of Ayaawo to migrate into southern Malawi. ${ }^{127}$ In the early 1980s, when Liesegang was conducting his research in Niassa, these attacks were no longer remembered in oral history. ${ }^{128}$ Between around 1845 and 1870, the Ayaawo and Nyanja suffered from more attacks. ${ }^{129}$ This time the attacks were by Ngoni groups making their way north through their lands. Also later, between around 1875 and 1897, another Ngoni group that had settled in southern Tanzania started attacking the Ayaawo and Nyanja. ${ }^{130}$ Overall, the Ngoni attacks, as Liesegang argues, played a significant role in militarizing the Ayaawo. Through the slave trade, the Ayaawo also gradually obtained more weapons from the coast. In 1897, the Ngoni attacks diminished due to the movement of the Germans to the Rovuma River. ${ }^{131}$ The Ngoni attacks were still remembered (though in very general detail) in the oral histories of the elders I interviewed in Niassa during my fieldwork. Also, many of the female ex-combatants spoke of hearing tales about the Ngoni wars from the elders while growing up before the liberation struggle. Otherwise, my interviewees lamented that they had left home too early to go to war and thus did not have much knowledge of these older histories.

\section{Militarization and the rise of the new chiefly dynasties}

The nineteenth century witnessed the emergence of new chiefly dynasties in the Yaawo country. ${ }^{132}$ The growing slave trade, especially, contributed to their 
rise to power. ${ }^{133}$ By the 1850 s, the Ayaawo were the major suppliers of slaves to the markets across the coast from Zanzibar to Quelimane (see Map 0.2 on page 19). ${ }^{134}$ Ce-Nyambi mentioned in the oral history narrative on page 21 was the founder of one of the most powerful dynastic lines in the first half of the nineteenth century, the Mataka dynasty. Other powerful territorial chiefs included Makanjila, Mponda, Mtalika, and Macemba, as well as Kawinga, Jalasi, and Matipiwiri. These chiefs all held the title of asyene cilaambo (chief of the land). ${ }^{135}$ In the oral histories still being told, this period was spoken of as the time when the people dispersed from the Yaawo hills. Each chief with his population settled on his mountain. From their mountains, they waged war against each other and raided each other for slaves. The higher ground that mountains provided was important for military strategy; it was an advantage point from which to wage attacks, and it offered safety from the attacks of others. By the 1860s, Mataka had emerged as the most powerful of all the Yaawo chiefs. Livingston's account of his visit to the capital of Mataka's state (still ruled by Ce-Nyambi) in Muembe in 1866 speaks of a large village of more than 1,000 houses. ${ }^{136}$ Ce-Bonomadi, who inherited the title Mataka III in 1885 and governed until 1903, is represented in oral tradition as a fierce warrior who evoked fear in his contemporaries. His capital in Muembe had more than 5,000 houses. ${ }^{137}$ He also famously fought against the occupation of the Portuguese and the agents of the Companhia do Nyassa (Niassa Company). ${ }^{138}$ When Bonomadi died in 1903, many Yaawo chiefs had already been subdued by the Portuguese. ${ }^{139}$ After Ce-Bonomadi, the power of the Mataka state started to weaken. This was induced by the decline of the slave trade and the increased influence of Portuguese colonialism in the area. ${ }^{140}$

\section{Spread of Islam}

By the mid-eighteenth century, the cultural influence of the Swahili coast was visible in the lifestyles of the Ayaawo: e.g., in architecture (the building of square houses that had verandas), in clothing (for instance, the capulana [Kiswahili: kanga]), in fruits: I was told that even the mango tree was introduced to the plateau via the coast, in the linguistic influence of Kiswahili and Arabic, and, moreover, through Islam. The Ayaawo started to convert to Islam in the second half of the nineteenth century. Liazzat Bonate argues that the main reason for their conversion was their involvement in the long-distance slave trade with the merchants of the Swahili coast. ${ }^{141}$ According to her, becoming a Muslim was an effective way of protecting oneself from turning into a target for slave raiders. Others such as Alpers emphasize the "modernizing" appeal that Islam must have had for the Yaawo leaders. ${ }^{142}$ Islam attracted people because of the "prestige that was associated with the Swahili culture, dress, building techniques and literacy." ${ }^{143}$ In the beginning, it was only the chiefs who converted. By the 1880s, the biggest Yaawo chiefs in Mozambique had become Muslims. ${ }^{144}$ There is some disagreement among scholars as to why ordinary people converted to Islam. Alan Thorold, who has conducted research on the Muslim identities of the Yaawo people in Malawi, argues that ordinary people 
converted to Islam through the initiation rite controlled by the chiefs. ${ }^{145}$ As the male initiation rite — called lupanda at the time- - was transformed to incorporate Islamic elements and renamed jando (as it is also known on the Swahili coast), a person who was initiated not only became a Yaawo but also a Muslim. Bonate is reluctant to emphasize this aspect but argues that the subjects of the chief in reality had no other option but to follow their chief. In the early twentieth century, Islam expanded even more strongly into Niassa through two Sufi orders: Shadhuliyah and the Qadiriyah. ${ }^{146}$ Bonate argues that these Sufi orders were so successful at least partly because they were "more egalitarian and inclusive than was the case when Islamic practices were controlled by the chiefs or the Swahili at the coast." ${ }^{147}$ Concurrently, with the new expansion of Islam, the power of the Yaawo chiefs declined as they were incorporated into the system of colonial administration. Moreover, Alpers suggests that the popular spread of Islam can also be explained by the fact that the social structure and educational system that it provided offered an "alternative means of self-assertion against a repressive Portuguese imperialism." "148 During Portuguese colonial rule, the Ayaawo for the most part resisted the mission education system. Most of the Yaawo ex-combatants that I interviewed remembered how they had not had the opportunity to study prior to the war because the only schools had been mission schools. Almost all of the Ciyaawo-speaking ex-combatants I interviewed identified as Muslims, mainly adherents of Qadiriyah.

\section{Portuguese colonization of Niassa}

At the end of the nineteenth century, the Portuguese started in earnest to expand into the interior of Niassa. The Berlin Conference of 1885 had established that only through the demonstration of "effective occupation" could a colonizing power claim a legal hold on its African territories. "Effective occupation" meant that law and order was to be maintained (thus local government had to be established), moreover, the colony had to be economically developed. ${ }^{149}$ In an effort to consolidate its control over its Eastern African territory, Portugal sent several expeditions to Niassa. ${ }^{150}$ At the time, Portugal was also facing competition from other European colonizing powers in the region. The British were asserting pressure at the margins of Lake Niassa and the Germans in northern Niassa. Through their expeditions, the Portuguese scrambled to sign treaties of vassalage with local chiefs and to ensure their support of Portuguese commercial interests in the area. ${ }^{151}$ In 1894, the Companhia do Nyassa (Niassa Company) - formally constituted in 1893-was granted concession over the territory between the Rovuma River in the north and the Lúrio River in the south (see Map 0.3 on page 25). ${ }^{152}$ Its charter was first signed for twenty-five years and then extended by ten more. Today, the area of Companhia do Nyassa belongs to the provinces of Cabo Delgado and Niassa.

Through the chartered companies, Portugal sought as cheaply as possible to establish administrative structures and to demonstrate that it effectively governed its territory. ${ }^{153}$ Meanwhile, the Portuguese army continued its "pacification 


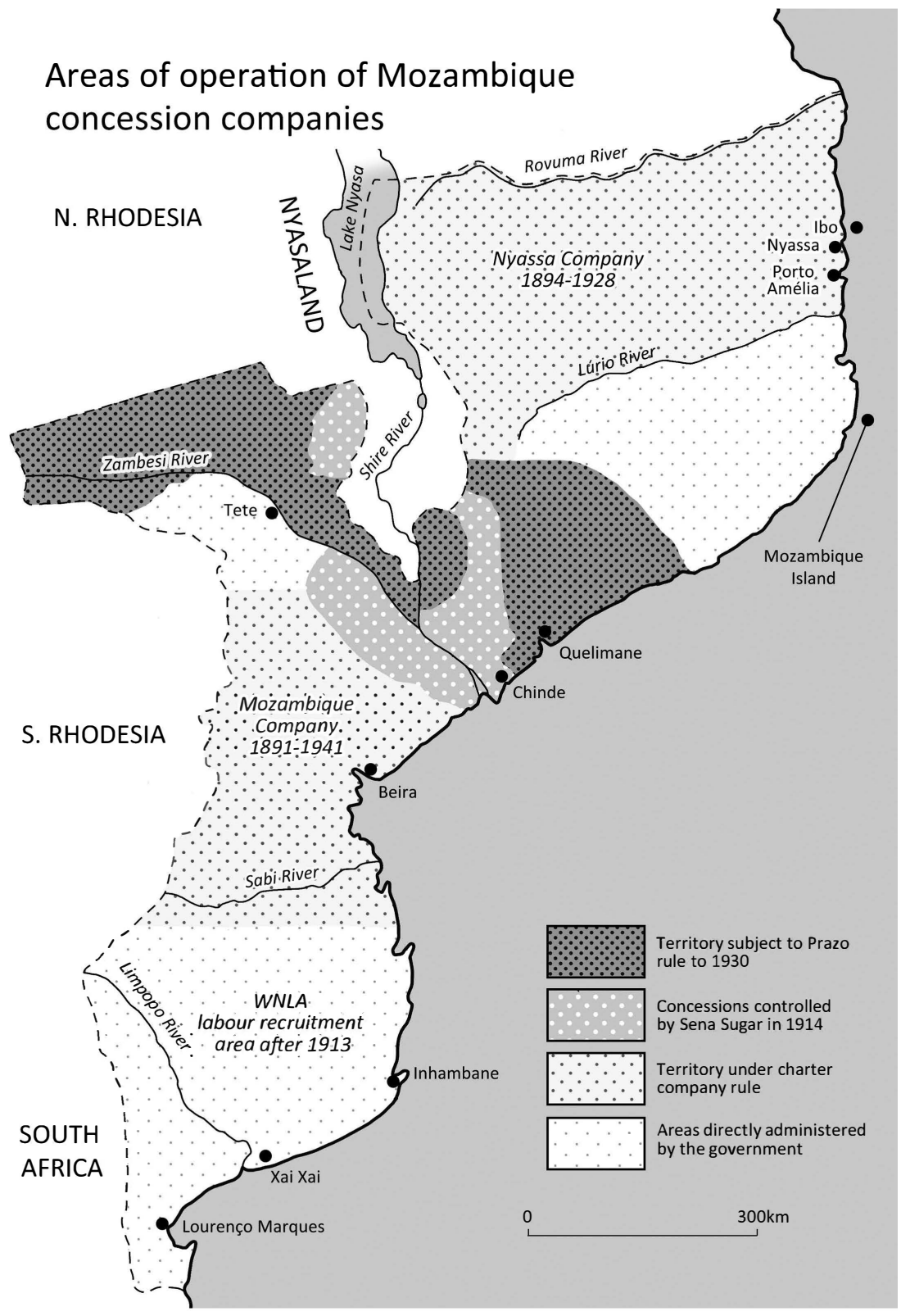

Map 0.3 Nyassa Company

Source: Malyn Newitt, History of Mozambique (London: Hurst and Company, 1994), 366. Map was redrawn by Noora Katto 
campaigns" against the chiefs who were still offering resistance. The Companhia do Nyassa, however, had serious problems raising capital. According to Newitt, the "first fifteen years of the Nyassa Company's life were, in so far as economic development or the establishment of a modern state were concerned, a farcical failure." ${ }^{154}$ While the Company managed to extend its line of posts from the coast to the lake, the Ayaawo in the interior (and especially Ce-Mataka) put up a strong military resistance that halted the advancement of the Company into their territories. ${ }^{155}$ Thus many Yaawo chiefs remained largely independent during the first fifteen years of Company rule. During this time, the Company did not manage to collect taxes or obtain labor levies in the interior. ${ }^{156}$ Newitt argues that only in 1908, due to the input of new capital, was the Company able to launch a stronger military campaign, finally defeating Ce-Mataka in 1912. ${ }^{157}$ Meanwhile, the population of Niassa suffered gravely from these military campaigns, and thousands of Ayaawo fled to Tanzania and Malawi. ${ }^{158}$ By the beginning of 1919, all chiefs were subdued and the whole of Niassa was brought under Portuguese colonial control. ${ }^{159}$ The Company rule was based on a system of economic exploitation. In 1912, the hut tax constituted the main source of profit for the Company. ${ }^{160}$ Another source of revenue was the sale of labor to other parts of Africa (e.g., Rand mines in South Africa and the Katanga mines in Northern Rhodesia). ${ }^{161}$ Moreover, the Company made a profit from ceding subconcessions to other companies. ${ }^{162}$ The Niassa Company offered no services for the people (such as schools or hospitals) or economic opportunities. Instead, it caused underdevelopment and the effective depopulation of Niassa, as masses of people fled its oppressive rule to neighboring countries. The populous settlements of the great chiefs (e.g., Mataka's village of 5,000 huts) became a thing of the past, and dispersed local settlements became the norm.

In 1929, the charter of Companhia do Nyassa was not renewed, and Portugal assumed direct control of its territory. The area was divided into two districts: Niassa and Cabo Delgado. ${ }^{163}$ With the rise of Salazar's Estado Novo, Portugal sought tighter economic and political subordination of its colonies. This transfer of control introduced no improvements for the population. Taxes actually increased, and the population continued to be harassed and abused in different ways. There was no development of the infrastructure, and some roads even disappeared into bush. ${ }^{164}$ Until the 1960s, health services were nonexistent, and shops and schools were few and far apart in the rural areas. In 1940, the Catholic mission was officially sanctioned responsible for African education in the colony. ${ }^{165}$ The Muslim Ayaawo for the most part refused to send their children to the mission schools. Instead, they had their own Koranic schools that taught literacy in Arabic. As a new initiative, the colonial government introduced forced cotton cropping into Niassa between 1937 and 1940. ${ }^{166}$ The system functioned so that concessionary companies were allocated land for growing cotton by the Portuguese government, which then divided the plots among the farmers. Later, these companies bought the cotton at fixed prices from them. The prices were very low compared to the prices being paid in 
neighboring countries and in comparison to the high taxes that the population was forced to pay. ${ }^{167}$ The high taxes and nonexistent economic opportunities caused many young men to seasonally migrate to neighboring countries to "find money" in order to support families back home. It is generally recognized that during the colonial period, Niassa was one of the most neglected areas of Mozambique. The elders I interviewed spoke of the "lack of money" in Mozambique at the time. Chehe ${ }^{168}$ Aji-who said he was born in 1914 "the year that the Germans were fighting with the Portuguese" 169 — was one of the oldest people I interviewed. He spoke of how he had for many years worked in Northern Rhodesia and in South Africa. He was away when his family moved from Metonia to the Lichinga plateau when the settlement of Vila Cabral was established by the Portuguese in 1931. He moved back to Niassa in 1945, after which he took part in several trips to Quelimane to sell tobacco. He also claims to have been the first African person from Mozambique and Malawi to have visited Mecca in 1957. Most of my female ex-combatant interviewees were born between the mid-1940s and early 1950s. They spoke of the how the male members of their families had also spent periods working in the neighboring countries and made trips to the coast to sell tobacco. Most of them were under the age of fifteen when FRELIMO started its armed campaign against the colonial regime in 1964.

\section{$\star \star \star$}

This final subchapter of the introduction has given a broad overview of the historical processes that have given shape to the area that became known as "Niassa" in the colonial period. The rest of this study is dedicated to a more in-depth exploration into the "Niassa" that materializes from the women excombatants' life narratives. Each of the three parts that constitute this study has a different analytical focus. The first part, "Talking Freedom," looks at the new gendered spatial discourse introduced by FRELIMO nationalism and the ways it shaped bodies and landscapes. The second part, "Violent Liberation," turns our attention to the body and sensory experience. Here, I study the making of the gendered combatant body during wartime; moreover, I examine the ways that the ex-combatant body continues to be negotiated in the female ex-combatants' accounts these days. In this part, I draw especially from sensory studies and affect theory. Finally, the third part, "Beautiful Belonging," brings into our analytical focus the in-between, the relational space between body and landscape. This in-between space it analyzed especially through the concepts of aesthetics and rhythm. Moreover, it is in this in-between space that I conceptualize belonging. Throughout these three parts, I examine the women's lived experiences and memories of Niassa, as well as the evolvement of their relationship with the national landscape. While each part has its analytical emphasis, the study continuously demonstrates the ways that material and discursive practices of body and space intersect and shape the ex-combatants' sense of personal and national space and belonging. 


\section{Notes}

1 In this study, I make a distinction between "FRELIMO," the liberation front, and "Frelimo," the political party.

2 There are three studies that focus on the liberation struggle in Niassa: David Francisco Xadreque Ndegue, $A$ luta de libertação na frente do Niassa, vol. 1 (Maputo: JV Editores, 2009); José Alberto Raimundo, "Frente do Niassa," in História da luta de libertação nacional, vol. 1, ed. Joel das Neves Tembe (Maputo: Direcção Nacional de História, Ministério dos Combatentes, 2014), 453-550; Sayaka Funada-Classen, The Origins of War in Mozambique: A History of Unity and Division (Oxford: African Minds, 2013). Two of the studies focus on the official FRELIMO history of the Niassa liberation front and draw on the oral testimonies of mostly male ex-combatants. The first one is written by David Francisco Xadreque Ndegue, who himself was closely associated with FRELIMO during the war. The second study was conducted by historian José Alberto Raimundo as part of a larger project by the Ministry of Combatants to write the history of the liberation struggle. The third is an academic study by Japanese researcher Sayaka FunadaClassen. Drawing on interviews as well as extensive research in archives, it focuses on the development of the war in Maúa district in southeastern Niassa.

3 Ute Luig and Achim von Oppen, "Landscape in Africa: Process and Vision," in The Making of African Landscapes, eds. Ute Luig and Achim von Oppen, 7-45. Vol. 43 of Paideuma, Mitteilungen zur Kulturkunde (Stuttgart: Steiner, 1997), 26. They refer to Ranger's conference paper, "New Approaches to African Landscapes," which he gave in Berlin in 1997.

4 Though no extensive studies have been conducted on female ex-combatants, the following scholars have importantly drawn attention to the topic in their research: Isabel Maria Casimiro, Transformação nas relações homem/mulher em Moçambique 1960-1974 (Tese de Licenciatura em História, UEM, 1986); Allen Isaacman and Barbara Isaacman, "The Role of Women in the Liberation of Mozambique," Ufahamu: Journal of the African Activist Association 13, no. 2 (1984): 128-185; Kathleen Sheldon, Pounders of Grain: A History of Women, Work, and Politics in Mozambique (Portsmouth, NH: Heinemann, 2002); Harry G. West, "Girls with Guns: Narrating the Experience of War of Frelimo's 'Female Detachment,'” Anthropological Quarterly 73, no. 4 (2000): 180-194; Marie José Arthur, "Mozambique: Women in the Armed Struggle," in Gender in Southern Africa in Transition: A Gendered Perspective, ed. Patricia McFadden (Harare: SAPES Books, 1998), 67-82; Liazzat Bonate, "Muslim Memories of the Liberation War in Cabo Delgado," Kronos 39, no. 1 (2013): 230-256.

5 See, e.g., Bonate, "Muslim Memories"; Victor Igreja, "Frelimo's Political Ruling through Violence and Memory in Postcolonial Mozambique," Journal of Southern African Studies 36, no. 4 (2010): 781-799; Michel Panzer, "The Pedagogy of Revolution: Youth, Generational Conflict, and Education in the Development of Mozambican Nationalism and State, 1962-1970," Journal of Southern African Studies 35, no. 4 (2009): 803-820; Ana Santos, "The Past in the Present: Memories of the Liberation Struggle in Northern Mozambique" (Paper presented at $7^{\circ}$ Congresso Ibérico de Estudos Africanos, Lisboa, September 2010).

6 Jonna Katto, "Landscapes of Belonging: Female Ex-Combatants Remembering the Liberation Struggle in Urban Maputo," Journal of Southern African Studies 40, no. 3 (2014): $539-557$.

7 In this study, I use the terms "life history," "life narrative," and "personal narrative" interchangeably. I understand these in the sense of "evolving series of stories [about one's life] that are framed in and through interaction." Thus I look at how past life experiences are interpreted (and remembered) in the interview talk. Catherine Kohler Riessman, "Analysis of Personal Narratives," in Handbook of Interview Research: Context \& Method, eds. Jaber F. Gubrium and James A. Holstein (Thousand Oaks: Sage, 2002), 6. See also e.g. Michael Bamberg, "Stories: Big or Small: Why Do We Care?" Narrative Inquiry 16, no. 1 (2006): 139-147. 
8 In Niassa, the liberation struggle was first initiated in the region of Lake Niassa in 1964. From there, the guerrillas advanced south to the area of Katur in 1965. In late 1965, a military front was also opened in the east in the area of Ce-Mataka in Mavago. Following the assassination of the secretary of defense Filipe Samuel Magaia in 1966, the Department of Defense was separated from the Department of Security. This also involved a restructuring of the provincial command structure. Due to its big size, Niassa was divided into three sectors of combat: the western sector (Niassa Ocidental), the eastern sector (Niassa Oriental), and the southern sector (Niassa Austral). The provincial base was located in the western sector, but the sectors (each with their own central base) had operational autonomy. The eastern sector was directly linked to the national command in Nachingwea due to its distance from the provincial base. Raimundo, "Frente do Niassa"; Ndegue, A luta de libertação; and see also José Phahlane Moiane, Memórias de um guerrilheiro (Maputo: King Ngungunyane Institute, 2009); Eduardo Nihia, M'toto: combatente pela liberdade (Maputo: UEMA, 2016). FRELIMO opened the Cabo Delgado war front in 1964 and the Tete front in 1968. War fronts were later opened in the central provinces of Manica and Sofala and Zambezia.

9 "DF" is also used to refer to the individual members of FRELIMO's female detachment (or Destacamento Feminino). Moreover, in this study, I use "female (ex-)combatant," "female (ex-)guerrilla fighter," and "female war veteran" interchangeably with "DF." I use "miliciana(s)" to refer to civilian women who participated in the war by carrying war material and cultivating food crops for the guerrillas.

10 According to ex-military commander of Niassa Oriental Eduardo Silva Nihia, in the later part of the war, FRELIMO's guerrilla force in Niassa amounted to about 2,000 soldiers. Interview with Eduardo Silva Nihia, Maputo, July 2, 2014. Henriksen estimates that in 1968, FRELIMO had about 4,000 soldiers, while the Portuguese forces consisted of about 50,000. By 1974, FRELIMO had 10,000 soldiers employed across the country. Thomas H. Henriksen, Mozambique: A History (London: Rex Collings, 1978), 190.

11 Anne McClintock "'No Longer in Future Heaven': Women and Nationalism in South Africa," Transition 51 (1991): 105.

12 For example, Tamara Mayer,"Nationalism: Setting the Stage," in Gender Ironies of Nationalism: Sexing the Nation, ed. Tamara Mayer (London: Routledge, 2000), 1-24; Joane Nagel, "Masculinity and Nationalism: Gender and Sexuality in the Making of Nations," Ethnic and Racial Studies 21, no. 2 (1998): 242-269; Cynthia Enloe, Bananas, Beaches and Bases: Making Feminist Sense of International Politics (Berkley: University of California Press, 1989); Elleke Boehmer, Stories of Women: Gender and Narrative in the Post-Colonial Nation (Manchester: Manchester University Press, 2005); Nira Yuval-Davis, Gender \& Nation (London: SAGE, 1997); Kumari Jayawardena, Feminism and Nationalism in the Third World (London: Zed Books, 1989 [1986]); Anne McClintock, "Family Feuds: Gender, Nationalism and the Family," Feminist Review 44 (1993): 61-80; Jyoti Puri, Encountering Nationalism (Oxford: Blackwell, 2004).

13 Enloe, Bananas, Beaches and Bases, 44.

14 Thembisa Waetjen,"The Limits of Gender Rhetoric for Nationalism: A Case Study from Southern Africa," Theory and Society 30, no. 1 (2001): 121-152. Waetjen further argues that her own study of Inkatha Zulu nationalism offers an exploration into a case in which masculinity fails to articulate well with nationalism, thus contradicting feminist studies that explicate the inherently supportive relationship between patriarchies and nations.

15 See also, e.g., Doreen Massey, "Politics and Space/Time," New Left Review 1, no. 196 (1992): 65-84; Anne McClintock, Imperial Leather: Race, Gender and Sexuality in the Colonial Contest (New York: Routledge, 1995); Elleke Boehmer, "Transfiguring: Colonial Body into Postcolonial Narrative," NOVEL: A Forum on Fiction 26, no. 3 (1993): 268-277; Gillian Rose, Feminism and Geography: The Limits of Geographical Knowledge (Cambridge: Polity Press, 1993).

16 My focus is especially on southern Africa and the Lusophone countries. See, e.g., Martha Akawa, The Gender Politics of the Namibian Liberation Struggle (Basel: Basler Afrika 
Bibliographien, 2014); Heike Becker, Namibian Women's Movement, 1980 to 1992: From Anti-Colonial Resistance to Reconstruction (Frankfurt [am Main]: IKO-Verlag für Interkulturelle Kommunikation, 1995); W. O. Maloba, African Women in Revolution (Trenton, NJ: Africa World Press, 2007); Richard E. Lapchick and Stephanie Urdang, Oppression and Resistance: The Struggle of Women in Southern Africa (London: Greenwood Press, 1982); Tanya Lyons, Guns and Guerrilla Girls: Women in the Zimbabwean Liberation Struggle (Trenton, NJ: Africa World Press, 2004); Josephine Nhongo-Simbanegavi, For Better or Worse: Women and ZANLA in Zimbabwe's Liberation Struggle (Harare: Weaver, 2000); Margarida Paredes, Combater duas vezes: mulheres na luta armada em Angola (Vila do Conde: Verso da História, 2015); Cora Ann Presley, Kikuyu Women, the Mau Rebellion, and Social Change in Kenya (Boulder, CO: Westview Press,1992); Iina Soiri, Radical Motherhood and Awakening Gender Awareness: Namibian Women's Independence Struggle (Helsinki: Helsingin yliopisto, 1994); Stephanie Urdang, Fighting Two Colonialism: Women in Guinea-Bissau (London: Monthly Review Press, 1979).

17 There are some exceptions. Notably, Sita Ranchod-Nilsson's study on women and gender in Zimbabwe's liberation struggle and Susan Geiger's study on TANU women explore how women actively participated in shaping nationalism(s). Ranchod-Nilsson, "(Gender) Struggles for the Nation," in Women, States and Nationalism: At Home in the Nation?, eds. Sita Ranchod-Nilsson and Mary Ann Tétreault (London: Routledge, 2000); Susan Geiger, TANU Women: Gender and Culture in the Making of Tanganyikan Nationalism 1955-1965 (Portsmouth, NH: Heinemann, 1997).

18 See also Joan W. Scott, "Gender: A Useful Category of Historical Analysis," The American Historical Review 91, no. 5 (1986): 1053-1075.

19 But at the same time, I am influenced by others who, similarly to Massey, understand landscape through the notions of multiplicity, movement, and open-endedness. My conceptualization of space and landscape draws on the neo-Marxist philosopher Henri Lefebvre's work on the social production of space, phenomenological perspectives in ecological anthropology (Tim Ingold), and heritage anthropology (Barbara Bender).

20 She discusses, for instance, Henri Bergson, Ernesto Lacau, and Michel de Certeau.

21 This is the conceptualization of space that underpins colonial histories of Africa. In these tales of spatial conquest, the spaces of the colonized are diminished into empty surface spaces, which only through the godly act of "discovery" are brought into historical existence. Doreen Massey, For Space (London: SAGE, 2005). See also Terence Ranger, “Making Zimbabwean Landscapes," Paideuma 43 (1997): 59-73. In more recent years, historians of Africa have also called for a more explicit focus on the role of space in African history. They have called for the acknowledgment of space as "an active factor in history." Allen M. Howard, "Actor, Places, Regions, and Global Forces: An Essay on the Spatial History of Africa Since 1700," in Respacing Africa, eds. Paul Nugent and Ulf Engel (Leiden: Brill, 2010), 11-44; Allen M. Howard and Richard M. Shain, eds., The Spatial Factor in African History: The Relationship of the Social, Material, and Perceptual (Leiden: Brill, 2005).

22 Massey, For Space, 59.

23 Ibid., 12.

24 Their relation is often theorized as dichotomous. See, e.g., Yi-Fu Tuan, Space and Place: The Perspective of Experience (Minneapolis: University of Minnesota, 1977); Tim Cresswell, Place: A Short Introduction (Malden, MA: Blackwell Publishers, 2004); Christopher Tilley, A Phenomenology of Landscape: Places Paths and Monuments (Oxford: Berg Publishers, 1994), 14; Edward S. Casey, "Body, Self, and Landscape: A Geophilosophical Inquiry into the Place-World," in Textures of Place: Exploring Humanist Geographies, eds. Paul C. Adams et al. (Minneapolis: University of Minnesota Press, 2001), 404-405.

25 Massey, For Space, 145.

26 Doreen Massey, Space, Place, and Gender (Minneapolis: University of Minnesota Press, 1994), 162. 
27 Doreen Massey, "Landscape as a Provocation: Reflections on Moving Mountains," Journal of Material Culture 11, nos. 1-2 (2006): 46.

28 See, e.g., Jeff Malpas, "Place and the Problem of Landscape," in The Place of Landscape: Concepts, Contexts, Studies, ed. Jeff Malpas (Cambridge, MA: MIT Press, 2011); Stephen Daniels and Denis Cosgrove, The Iconography of Landscape (Cambridge: Cambridge University Press, 1988); Denis Cosgrove, "Prospect, Perspective and the Evolution of the Landscape Idea," Transactions for the Institute of British Geographers 10 (1985): 45-62. See also Michael Bollig, "Visions of Landscape: An Introduction," in African Landscapes. Interdisciplinary Approaches, eds. Michael Bollig and Olaf Bubenzer (New York: Springer, 2009), 1-38. Bollig, interestingly, shows that contrary to the strong association of landscape with the visual in the English language, landscape (lantschaft) in German has a more varied history of changing meanings.

29 See also Barbara Bender, "Introduction," in Contested Landscapes: Movement, Exile and Place, eds. Barbara Bender and Margot Winer (Oxford: Berg, 2001), 1-18; Barbara Bender, "Time and Landscape," Current Anthropology 43, no. S4 (2002): S103-S112.

30 Jeff Malpas accuses Massey of conflating the notions of space and place. Jeff Malpas, "Putting Space in Place: Philosophical Topography and Relational Geography," Environment and Planning D: Society and Space 30 (2012): 226-242. Yet Massey herself argues that their separation is counterproductive and confines our understanding of the spatial.

31 Following a feminist phenomenological understanding, not only sensory perceptions but also our cognitive interpretations are constitutive of experience. This involves thinking discourse and materiality together in an intertwined relationship. See, e.g., Linda Alcoff, "Phenomenology, Post-structuralism, and Feminist Theory on the Concept of Experience," in Feminist Phenomenology, eds. Linda Fisher and Lester Embree (Dordrecht: Kluwer Academic Publishers, 2000), 48; Elizabeth Grosz, "Merleau-Ponty and Irigaray in the Flesh," Thesis Eleven 36 (1993): 37-59.

32 A feminist phenomenological approach in my study entails a close analysis of my interviewees' talk about their lived landscape experiences and memories, which involves situating and examining this embodied talk and meaning making within its larger intersubjective context. See also Eva-Maria Simms and Beata Stawarska,"Introduction: Concepts and Methods in Interdisciplinary Feminist Phenomenology," Janus Head 13, no. 1 (2014): 6-16.

33 See also Barbara Bender, Sue Hamilton, and Chris Tilley, eds., Stone Worlds: Narrative and Reflexivity in Landscape Archaeology (Walnut Creek, CA: Left Coast Press, 2007); Tim Ingold, “The Temporality of the Landscape," World Archaeology 25, no. 2 (1993): 152-174.

34 Ingold, "Temporality of the Landscape," 154; See also David William Cohen and E. S. Atieno Odhiambo, Siaya: The Historical Anthropology of an African Landscape (London: James Currey, 1989); Ranger, “Making Zimbabwean Landscapes”; Steven Feld and Keith H. Basso, eds., Senses of Place (Santa Fe: School of American Research Press, 1996).

35 Bronwyn Davies, (In)scribing Body/landscape Relations (Walnut Creek, CA, Altamira, 2000). See also Casey, "Body, Self, and Landscape"; Edward S. Casey, "How to Get from Space to Place in a Fairly Short Stretch of Time: Phenomenological Prolegomena," in Senses of Place, 13-52.

36 Lisa Folkmarson Käll argues that this is something that especially feminist scholars have sought to emphasize. "Vulnerable Bodies and Embodied Boundaries," in Bodies, Boundaries and Vulnerabilities: Interrogating Social, Cultural and Political Aspects of Embodiment, ed. Lisa Folkmarson Käll (London: Springer, 2016), 1-12.

37 Massey, "Landscape as a Provocation."

38 See, e.g., Luig and von Oppen, "Landscape in Africa," 27; Jan Bender Shetler, Imagining Serengeti: A History of Landscape Memory in Tanzania from Earliest Times to the Present (Athens: Ohio University Press, 2007); Ranger, "Making Zimbabwean Landscapes"; Terence Ranger, "African Views of the Land: A Research Agenda," Transformations 44 


\section{Introduction}

(2000), 53-62; Cohen and Odhiambo, Siaya; Terence Ranger, Voices from the Rocks: Nature, Culture and History in the Matopos Hills of Zimbabwe (Oxford: James Currey, 1999); Jekura U. Kavari and Laura Bleckmann, "Otjiherero Praises of Places: Collective Memory Embedded in Landscape and the Aesthetic Sense of a Pastoral People," in African Landscapes, 473-501; Ute Dieckmann, "The Spectator's and the Dweller's Perspectives: Experience and Representation of the Etosha National Park, Namibia," in African Landscapes, 353-381.

39 Ranger, "Making Zimbabwean Landscapes"; Ranger, Voices from the Rocks. For other examples, see, e.g., Patricia Hayes, "A Land of Goshen: Landscape and the Kingdom in Nineteenth Century Eastern Owambo (Namibia)," in African Landscapes, 225-254.

40 Howard, "Actor, Places, Regions, and Global Forces."

41 Luig and von Oppen, "Landscape in Africa," 26.

42 See, e.g., Yi-Fu Tuan, "Language and the Making of Place: A Narrative-Descriptive Approach," Annals of the Association of American Geographers 81, no. 4 (1991): 684-696.

43 Henri Lefebvre, The Production of Space (Oxford: Blackwell, 1991), 39.

44 Christian Schmid, "Henri Lefebvre's Theory of the Production of Space: Towards a Three-Dimensional Dialectic," in Space, Difference, Everyday Life: Reading Henri Lefebvre, eds. Kanishka Goonewardena et al. (New York: Routledge, 2008), 39.

45 See also Ranger, "African Views of the Land," 60.

46 As Christian Schmid argues, Lefebvre's notion of "lived space" is influenced by the French phenomenologists, including Merleau-Ponty. See Schmid, "Henri Lefebvre's Theory."

47 One significant point of contestation between social constructivists and feminist phenomenologists concerns sexual difference and the question of whether it is understood as a linguistic effect or if it has a metaphysical basis. See Sara Heinämaa, "A Phenomenology of Sexual Difference: Types, Styles and Persons," in Feminist Metaphysics: Explorations in the Ontology of Sex, Gender and Identity, ed. Charlotte Witt (London: Springer, 2011), 132; Judith Butler, "Performing Acts and Gender Constitution: An Essay in Phenomenology and Feminist Theory," Theatre Journal 40, no. 4 (1988): 519-531. See also Alcoff, "Phenomenology, Post-structuralism, and Feminist Theory."

48 See Catherine Nash, "Performativity in Practice: Some Recent Work in Cultural Geography," Progress in Human Geography 24, no. 4 (2000): 653-664.

49 See also Silvia Stoller, "Expressivity and Performativity: Merleau-Ponty and Butler," Continental Philosophy Review 43, no. 1 (2010): 97-110. Stoller argues that Merleau-Ponty's notion of expressivity and Butler's concept of performativity are both antiessentialist.

50 Judith Butler, Gender Trouble (London: Routledge, 2006 [1990]), 34.

51 Butler, "Performing Acts," 522.

52 For Butler, "sex" and "gender" are both discursive constructs. Butler, Gender Trouble, 9; Judith Butler, Bodies that Matter: On the Discursive Limits of "Sex" (London: Routledge, 1993). Heinämaa argues that "construction" builds on an idea of "raw material" that is gendered/sexed into culturally conceivable "men" and "women." It thus implies a causal relationship between "organic material" and "the machinery of sex/gender." Sara Heinämaa, "Sex, Gender and Embodiment," in The Oxford Handbook of Contemporary Phenomenology, ed. Dan Zahavi (Oxford: Oxford University Press, 2012), 227-228.

53 Heinämaa,"A Phenomenology of Sexual Difference,"149; Lisa Folkmarson Käll,“A Being of Two Leaves - On the Founding Significance of the Lived Body," in Body Claims, eds. Janne Bromseth, Lisa Folkmarson Käll, and Katarina Mattsson (Uppsala: University Printers, 2009), 127; Sara Heinämaa, Ele, Tyyli ja Sukupuoli: Merleau-Pontyn ja Beauvoirin Ruumiinfenomenologia ja Sen Merkitys Sukupuolikysymykselle (Tampere: Tamperepaino, 1996), 160.

54 Käll, "Being of Two Leaves," 118.

55 Ibid., 124.

56 Ibid., 125. In this sense, the gendered body is shaped through the intertwined dimensions of exteriority and interiority. 
57 Sara Heinämaa, "Woman-Nature, Product, Style?: Rethinking the Foundations of Feminist Philosophy of Science," in Feminism, Science, and the Philosophy of Science, eds. Lyn Hankinson Nelson, and Jack Nelson (London: Kluwer Academic Publishers, 1996), 302.

58 Butler, "Performing Acts," 522.

59 Heinämaa, Ele, Tyyli ja Sukupuoli.

60 See also Chandra Talpade Mohanty, Feminism without Borders: Decolonizing Theory, Practicing Solidarity (Durham: Duke University Press, 2003).

61 Ifi Amadiume, Male Daughters, Female Husbands: Gender and Sex in African Society (London: Zed Books, 1987), 185.

62 Oyèrónké Oyěwùmí, "Conceptualizing Gender: Eurocentric Foundations of Feminist Concepts and the Challenge of African Epistemologies," in African Gender Scholarship: Concepts, Methodologies and Paradigmsi, eds. Signe Arnfred et al. (Dakar, Senegal: Council for the Development of Social Science Research in Africa, 2004), 1-8; Oyèrónké Oyĕwùmí, The Invention of Women: Making an African Sense of Western Gender Discourses (London: University of Minnesota, 1997); Oyèrónké Oyěwùmí, "Decolonizing the Intellectual and the Quotidian: Yorùbá Sholars(hip) and Male Dominance," in Gender Epistemologies in Africa: Gendering Traditions, Spaces, Social Institutions, and Identities, ed. Oyèrónké Oyěwùmí (New York: Palgrave Macmillan, 2011), 1-30; see also Chandra Talpade Mohanty, "Under Western Eyes: Feminist Scholarship and Colonial Discourses," in Third World Women and the Politics of Feminism, eds. Chandra Talpade Mohanty et al. (Indianapolis: Indiana University Press, 1991), 51-80.

63 See, e.g., Heinämaa, "A Phenomenology of Sexual Difference," 136; Johanna Oksala, "A Phenomenology of Gender," Continental Philosophy Review 39 (2006): 241.

64 Käll, "Being of Two Leaves," 125. For our research to be interactive in a real sense, we need to be prepared and willing to have our own ideas and ways of thinking challenged. See also Leslie H. Townsend, "Interactive Women's Life Histories," History in Africa 17 (1990): 351-358. Following Spivak, learning to respond to others involves unlearning our own privilege. Gayatri Chakravorty Spivak, A Critique of Postcolonial Reason: Toward a History of the Vanishing Present (London: Harvard University Press, 1999), 198-311; Gayatri Chakravorty Spivak, "Criticism, Feminism, and the Institution," in The PostColonial Critic: Interviews, Strategies, Dialogues, ed. Sarah Harasym (New York: Routledge, 1990), 1-16. See also Linda Alcoff, "The Problem of Speaking for Others," Cultural Critique 20 (1991): 5-32.

65 Carole S. Vance, "Pleasure and Danger: Toward a Politics of Sexuality," in Pleasure and Danger: Exploring Female Sexuality, ed. Carole S. Vance (London: Pandora Press, 1989), 17. See also e.g. Leslie McCall, “The Complexity of Intersectionality," Signs: The Journal of Women in Culture and Society 30, no. 3 (2005): 1771-1800; Kathy Davies, "Intersectionality as Buzzword: A Sociology of Science Perspective on What Makes a Feminist Theory Successful," Feminist Theory 9, no. 1 (2008): 67-85; Bibi Bakare-Yusuf, “'Yorubas Don't Do Gender': A Critical Review of Oyeronke Oyewumi's The Invention of Women: Making an African Sense of Western African Discourses," in African Gender Scholarship, 61-81.

66 The most widely spoken languages in Niassa are Ciyaawo, Cinyanja, and Emakhuwa. Ciyaawo is spoken by approximately 37 percent of the population, Cinyanja by 10 percent, and 43 percent of the people are Emakhuwa-speakers. Instituto Nacional de Estatística (hereafter INE), Recenseamento geral da população e habitação 2007: Indicadores socio-demográficos: Província de Niassa (Maputo: INE, 2007). I decided to focus my efforts in language acquisition on Ciyaawo because even though it is widely spoken in Niassa, many of the leading figures of the liberation struggle from Niassa who later gained important positions in the Frelimo government are Cinyanja-speakers. This is largely due to the fact that while the Muslim Ayaawo resisted sending their children to the mission schools during colonial times, the Nyanja were better able to benefit from the system. In the postindependence period, the Ciyaawo-speaking ex-combatants were marginalized in relation to the Cinyanja-speakers because of their lack of formal 


\section{Introduction}

education. In my research, I wanted to focus on those DFs whose voices are less heard in the public sphere.

67 Altogether, I worked in six districts: Sanga (the localities of Malulu, Macaloge, and Matchedje), Majune (the locality of Majune, the administrative center of the district), Mavago (Mavago sede, N'sawisi, and N'kalapa), Muembe (Muembe sede, Chiconono, and Nzizi), Lago (Maniamba and Metangula), the district of Lichinga (Kolongo and Mussa), and Lichinga municipality.

68 Jo Lee and Tim Ingold, "Fieldwork on Foot: Perceiving, Routing, Socializing," in Locating the Field: Space, Place and Context in Anthropology, eds. Simon Coleman and Peter Collins (New York: Berg, 2006), 79-80.

69 The members of ACLLN are usually also members of the Frelimo party, though this is not written into the statute. The association is headed by the president of Frelimo. See ACLLN, "Estatutos e Programa" (2006), http://aclln.org.mz/Estatutos_e_Programa_ da_ACLLN.pdf. Curiously, though in Maputo, ACLLN's role was understood more in terms of promoting the rights and well-being of the ex-combatants, in Niassa, the provincial secretary argued that the primary objective of ACLLN was to "defend the politics of Frelimo." Interview with Rui Cabinda, the provincial secretary of ACLLN, Lichinga, June 24, 2014.

70 Most ex-combatants were generally unwilling to give interviews without the assurance that the interviews had been approved by ACLLN. In the beginning of my research, my close connection with ACLLN worried me, and I was concerned that the association could attempt to control my research or that this connection might alienate some interviewees. However, to my relief, it turned out that after the first visit to each district, which often involved being more closely accompanied by our ACLLN host, on subsequent visits, Helena and I were able to negotiate space to go about our research quite independently.

71 I was also careful to make sure that my research participants did not have false expectations of forthcoming benefits (such as new income-generating projects, better pensions). What I did promise was to write a separate popular book that would document their life histories as DFs. This idea took shape during the research process when together with the women we discussed my research agenda and their expectations for the project. Many women lamented the fact that they were unable to write their life stories themselves (contrary to some of their male ex-colleagues in Maputo). They wanted a book that would remind their children and grandchildren of what their mothers and grandmothers had done during the war. In October 2018, I was finally able to deliver copies of the finished book to all my research participants in Niassa. See Jonna Katto, ' $A$ avó foi guerrilheira': memórias de vida das mulheres que lutaram pela independência de Moçambique no norte do Niassa / 'Grandma was a Guerrilla Fighter': Women who Fought for Mozambique's Independence in Northern Niassa, Portuguese translation by João Figueiredo (Tallinna, 2018).

72 See also, e.g., Tina Miller and Linda Bell, "Consenting to What? Issues of Access, GateKeeping and 'Informed' Consent," in Ethics in Qualitative Research, eds. Tina Miller et al. (London: SAGE, 2012), 61-76; Julia O'Connell Davidson, "If No Means No, Does Yes Mean Yes? Consenting to Research Intimacies," History of the Human Sciences 21, no. 4 (2008): 49-67.

73 All women were fluent in Ciyaawo, though two of the women were not first-language speakers. One DF was a first-language speaker of Cinyanja and another of Emakhuwa. Some of the women living in Lichinga were comfortable speaking Portuguese. Those who were able to speak Portuguese generally chose to speak it in the interviews. Also, many of the others who spoke Ciyaawo in the interviews seemed to have some understanding of Portuguese, though they were less comfortable speaking it. I conducted most of my Portuguese interviews alone.

74 Since the municipality of Lichinga has the highest number of DFs (possibly up to seventy), I interviewed fourteen DFs there. I interviewed one DF in the district of Lichinga, 
five in the Muembe, six in Sanga, six in Mavago, and two in Maniamba in the Lago district. I also interviewed one DF who had been trained after the Acordos de Lusaka.

75 In Sanga, we interviewed two groups of two men (in Matchedje and in Malulu). In Mavago sede, Muembe sede, and Cidade de Lichinga we interviewed a group of three men in each place.

76 Following Armindo Ngunga and Osvaldo G. Faquir, I use "Yaawo" (pl. "Ayaawo") instead of the more commonly used "Yao." Padronização da ortografia de línguas moçambicanas: relatório do III seminário (Maputo: CEA, 2011).

77 See also, e.g., Martha Norkunas, "The Vulnerable Listener," in Oral History Off the Record: Towards an Ethnography of Practice, eds. Anna Sheftel and Stacey Zembrzycki (New York: Palgrave Macmillan, 2013), 81-96.

78 This was also a question of learning and adjusting one's research to local codes of ethics so as not to be considered intrusive. See Emídio Gune and Sandra Manuel, "Doing Research on Sexuality in Africa: Ethical Dilemmas and the Positioning of the Researcher," OSSEREA Bulletin 4, no. 2 (2007): 23-32.

79 We also usually sought to make these interviews into female-only spaces, as this seemed to create a more relaxed atmosphere. As I soon discovered, this was easily accomplished by informing the male ACLLN representatives (and any other men present) that we would be discussing unyago (the initiation rite).

80 See, e.g., Donna Haraway, "Situated Knowledge: The Science Question in Feminism and the Privilege of Partial Perspective." Feminist Studies 14, no. 3 (1988): 575-599.

81 In cases where participants themselves request that their identities be protected, this is, of course, the only viable ethical choice. For instance, Maria Paula Meneses writes of how many of the people she interviewed on their experiences of political violence "chose anonymity." She suggests that this was due to the emotionally sensitive nature of the topic and the fact that the experiences and narratives of these people continue to be officially unrecognized by Frelimo. Maria Paula Meneses, "Xiconhoca, o inimigo: narrativas de violência sobre a construção da nação em Moçambique," Revista Crítica de Ciências Sociais 106 (2015): 9-51.

82 See Joan C. Tronto for her discussion on the issue of authority and autonomy in the relationship between the carer and the cared for. Tronto, "Women and Caring: What Can Feminists Learn about Morality from Caring?," in Gender/Body/Knowledge: Feminist Reconstructions of Being and Knowing, eds. Alison M. Jaggar and Susan R. Bordo (New Brunswick: Rutgers University Press, 1989).

83 Katja M. Guenther, "The Politics of Names: Rethinking the Methodological and Ethical Significance of Naming People, Organizations, and Places," Qualitative Research 9, no. 4 (2009): 420.

84 Nancy Schepher-Hughes, “Ire in Ireland," Ethnography 1, no. 1 (2000): 128.

85 In the transcription of the Ciyaawo texts, we sought for the most part to follow the orthographic conventions outlined in the CEA seminar on the standardization of the orthography of the Mozambican languages organized in Maputo in 2008. We chose, however, not use tone marks. See Ngunga and Faquir, Padronização da ortografia.

86 I present the original transcripts alongside English translations only when Ciyaawo and Portuguese are both used in the interview excerpt.

87 See also Townsend, "Interactive Women's Life Histories." Townsend discusses the importance of ensuring that the readers can evaluate how the interaction between the researcher and research participants has shaped the research material. I think a verbatim transcription further supports this aim.

88 See Haraway, “Situated Knowledge," 581.

89 As Luise White argues, lives cannot be read as texts. Rather, "they are lived, interpreted, contextualized, spoken about, reflected on, and highly contested." Luise White, "Anthologies of Women in Africa," Canadian Journal of African Studies 28, no. 1 (1994): 127-133.

90 Judith Stacey, "Can There Be a Feminist Ethnography?” Women's Studies International Forum 11, no. 1 (1988): 21-27. 
91 Mohanty, "Under Western Eyes."

92 Ibid., 52.

93 Doreen Massey, “Landscape/Space/Politics: An Essay” (2010), accessed May 4, 2016, http://thefutureoflandscape.wordpress.com/landscapespacepolitics-an-essay.

94 Yohannah B. Abdallah, The Yaos (Chiikala Cha Wayao) (London: Frank Cass and Company, 1973 [1919]), 28.

95 Manuel Gama Amaral, O povo Yao: subsídios para o estudo de um povo do noroeste de Moçambique, Tese de Licenciatura em Antropologia, Universidade Técnica de Lisboa, 1968 (Lisboa: Instituto de Investigação Científica e Tropical, 1990), 45. See also, James Clyde Mitchell, The Yao Village: A Study in the Social Structure of a Nyasaland Tribe (Manchester: Manchester University, 1956), 22; Frederico José Peirone, Tribo Ajaua do alto Niassa (Moçambique) e alguns aspectos da sua problemática neo-islâmica (Lisbon: Instituto de Investigação Científica Tropical [IICT], 1967).

96 Edward A. Alpers, "Trade, State and Society among Yao in the Nineteenth Century," Journal of African History 10, no. 3 (1969): 406. Gaspar Bocarro's journey from Tete through Yaawo country to Kilwa in 1616 has been documented in Antonio Bocarro's "Livro do Estado da India."

97 Alan Thorold, “The Persistence of a Tribe," Alternation 2, no. 2 (1995): 80. Gerhard Liesegang suggests that it is probable that the people mentioned by Bocarro "the Nguru" were the ancestors of the Ayaawo. Gerhard Liesegang, História do Niassa ca. 1600-1918: Estados, política e economia no período precolonial e a conquista colonial (unpublished manuscript, Maputo, n.d.).

98 He refers to Rangely, who claiming Portuguese sources, argues that by 1768 the Ayaawo were trading at Kilwa. According to Alpers, slightly before this in 1736 a French trader makes mention of the presence of the Ayaawo on the coast of Mozambique Island. Edward A. Alpers, Ivory and Slaves: Changing Pattern of International Trade in East Central Africa to the Later Nineteenth Century (Berkeley: University of California Press, 1975), 76.

99 There is even less knowledge about the role of women in this trade. For instance, Benigna Zimba's study shows that men were not the sole actors but women are in various ways contributed to long-distance trade in Southern Mozambique. See Benigna Zimba, Mulheres invisiveis: o género e as políticas comercíais no sul de Moçambique, 17201830 (Maputo: Promedia, 2003).

100 Alpers, "Trade, State and Society," 406.

101 Malyn Newitt, A History of Mozambique (London: Hurst and Company, 1995), 178179; 247; Alpers, Ivory and Slaves, 79-81.

102 Newitt, History of Mozambique, 184. The Ayaawo took over from the Maravi, who had previously controlled trade in the area of northern Mozambique.

103 Ibid.

104 Gerhard Liesegang, "Guerras, terras e tipos de povoações: sobre uma 'tradição urbanistica' do norte de Moçambique no seculo XIX," Revista Internacional de Estudos Áfricanos 1 (1984): 171. Liesegang argues that due to the lack of sources, it is not possible to say much about the social and political organization of the Ayaawo and Nyanja before 1830. However, he claims that it is likely that the Yaawo and Nyanja societies were organized into various matrilineages and regional groups. Gerhard Liesegang, "A estrutura política, a estratificação social e o lugar dos chefes na estrutura económica e religiosa antes da conquista colonial," in História do Niassa, vol. 1 (Maputo, unpublished manuscript, 2014 [1990?]); see also Eduardo da Conceição Medeiros, História de Cabo Delgado e do Niassa (C 1836-1927) (Maputo: Central Impressora, 1997), 81.

105 Liesegang, "Guerras, terras e tipos de povoações," 171. It appears that ethnicity was a relatively fluid identity category. See also Edward A. Alpers, "The Yao in Malawi: The Importance of Local Research," in The Early History of Malawi, ed. Bridglal Pachai (London: Longman, 1972), 169.

106 Mitchell, Yao Village, 34-35. Thorold writes that the chiefs and headmen controlled initiation ceremonies and were thus the "gatekeepers of Yao identity." He argues that 
to become Yaawo, one did not have to have Yaawo ancestry, belong to a Yaawo clan, or speak fluent Ciyaawo. One only had to undergo initiation. This is why even adult slaves were initiated. Thorold, "The Persistence of a Tribe," 87-88.

107 Mitchell, Yao Village, 36-37.

108 Liesegang, "A estrutura política."

109 Ibid.

110 Ibid.

111 See also Duff MacDonald, Africana or the Heart of Heathen Africa, vol. 1 (London: Simpkin Marchall and Co., 1882), 155-157. MacDonald was a missionary of the Church of Scotland in southern Malawi.

112 Liesegang, "A estrutura política”; Alpers, "Trade, State and Society,” 407.

113 Liesegang, "A estrutura política."

114 Ibid.

115 Alpers, “Trade, State and Society," 411.

116 Ibid.

117 Ibid., 412.

118 Abdallah, Yaos, 50.

119 Liesegang, "A estrutura política."

120 Ibid.

121 See also Benigna Zimba, “'Achivanjila I” and the Making of the Niassa Slave Routes," in Slave Routes and Oral Tradition in Southeastern Africa, eds. Benigna Zimba et al. (Maputo: Filsom Entertainment, 2005), 219-251. Zimba writes of the of the powerful mbopesi of Queen Achivanjila I, which, according to Yaawo oral history, significantly contributed to the success of the slave raids during the reigns of Mataca I and Mataca II.

122 Also women can be appointed to the position of Mwenye.

123 Interview with Asigale N'talika Mataka, Mavago district, June 1, 2014. Interview with Bibi Acivaanjila and Ce-Tasona Cipanda, Majune district, June 5, 2014. Interview with Bibi Ce-Kavanjala, Chiuanjota, Muembe district, June 10, 2013.

124 Liesegang, "Guerras, terras e tipos de povoações," 171-172.

125 Abdallah, Yaos, 35.

126 See Alpers, "Yao in Malawi," 170.

127 For more on the Yaawo migration into Malawi, see Nancy Northrup, "The Migrations of Yao and Kololo into Southern Malawi: Aspects of Migrations in Nineteenth Century Africa," The International Journal of African Historical Studies 19, no. 1 (1986): 59-79; Mitchell, Yao Village; Alpers, "Yao in Malawi”; Hugh S. Stannus, “The Wayao of Nyasaland," in Harvard African Studies, vol. 3, eds. E. A. Hooton and N. I. Bates (Cambridge, MA: Harvard University Press, 1922), 229-372.

128 Liesegang, "Guerras, Terras e Tipos de Povoações," 172.

129 Ibid.

130 Ibid.

131 Ibid.

132 It is unknown if this is a completely new phenomenon or if equally powerful chiefs had existed before but had been pushed aside by the new chiefs. See Alpers, "Trade, State and Society," 407.

133 Alpers, "Trade, State and Society," 407. Between 1760 and 1880, the slave trade increases in volume in the region. Liesegang, História do Niassa.

134 See Medeiros, História de Cabo Delgado e do Niassa, 86.

135 Mitchell, Yao Village, 33-34. Alpers, "Trade, State and Society," 413. With Islamization, the highest ranking chiefs started to use the title "sultão." See Medeiros, História de Cabo Delgado e do Niassa, 93.

136 Mentioned in Medeiros, História de Cabo Delgado e do Niassa, 87.

137 Ibid., 88-89.

138 Ibid.

139 Ibid. 
140 Ibid., 90.

141 Archaeological finds show that coastal Mozambique, together with the Eastern African coast, has been part of the Indian Ocean trade network since at least the eighth century. This suggests that Islam also has a long history in the region. Liazzat Bonate, "Islam in Northern Mozambique: A Historical Overview," History Compass 8/7 (2010): 573-593.

142 Edward A. Alpers, "Towards a History of the Expansion of Islam in East Africa: The Matrilineal Peoples of the Southern Interior," in The Historical Study of African Religion, eds. Terence O. Ranger and Isaria N. Kimambo (Ann Arbor, MI: UMI, 1997), 172-201.

143 Newitt, History of Mozambique, 438.

144 See Liazzat Bonate "Yao, Islam and the," Oxford Islamic Studies Online, accessed July 13, 2012, www.oxfordislamicstudies.com/article/opr/t343/e0055; S. Von Sicard, "Islam in Mozambique: Some Historical and Cultural Perspectives," Journal of Muslim Minority Affairs 28, no. 3 (2008): 473-490; Alpers, "Trade, State and Society," 420.

145 Thorold, "The Persistence of a Tribe."

146 Bonate, "Yao, Islam"; see also Bonate, "Islam in Northern Mozambique." According to her, both orders were first established at Mozambique Island. Bonate argues that because Islamic authority was not contested by the Arabs in northern Mozambique, matrilineal people like the Ayaawo were able to oppose Islamic patriliny and hold on to matrilineal decent and inheritance. See also Bonate, "Matriliny, Islam and Gender in Northern Mozambique," Journal of Religion in Africa 2, no. 36 (2006): 139-166. Alpers argues that it was a separate branch of the Qadiriyah that entered Niassa through Nyasaland and Tanganyika. Edward A. Alpers, "Islam in the Service of Colonialism? Portuguese Strategy during the Armed Liberation Struggle in Mozambique," Lusotopie (1999): 165-184.

147 Bonate, "Yao, Islam."

148 Alpers, "Yao in Malawi." Alpers makes his argument based on the study by Frederico José Peirone among the Ayaawo of Mozambique. Peirone, Tribo Ajaua do alto Niassa.

149 See, e.g., Leroy Vail, "Mozambique's Chartered Companies: The Rule of the Feeble," Journal of African History 17, no. 3 (1976): 390.

150 See, e.g., Medeiros, História de Cabo Delgado e do Niassa, 119; Newitt, History of Mozambique, 372 .

151 For example, Camilo Manuel Silveira da Costa, O Niassa visto por dentro (Lisboa: Boletem Geral do Ultramar, 1959).

152 Newitt, History of Mozambique, 372.

153 Vail, “Mozambique's Chartered Companies," 389.

154 Newitt, History of Mozambique, 373.

155 Ibid., 373, 398.

156 Ibid., 398.

157 Ibid. See also Liesegang, História do Niassa.

158 Medeiros, História de Cabo Delgado e do Niassa, 91; Vail, "Mozambique’s Chartered Companies," 402.

159 Liesegang, História do Niassa.

160 Vail, "Mozambique's Chartered Companies," 399. See also Barry Neil-Tomlinson, "The Nyassa Chartered Company: 1891-1929," The Journal of African History 18, no. 1 (1977): 109-128; Rosemary Elizabeth Galli, Peoples' Spaces and State Spaces: Land and Governance in Mozambique (Oxford: Lexington Books, 2003).

161 Vail, "Mozambique's Chartered Companies," 399-340.

162 Ibid.

163 For a detailed overview of the numerous administrative reforms that the area of "Niassa" underwent throughout the colonial period, see Nuno Beja Valdez Thomaz dos Santos, O desconhecido Niassa (Lisboa: Junta de Investigação do Ultramar, 1964), 106-10 7; Silveira da Costa, Niassa visto por dentro, 29-32.

164 Galli, Peoples' Spaces, 32-35. 
165 Kathleen Sheldon, “I Studied with the Nuns, Learning to Make Blouses': Gender Ideology and Colonial Education in Mozambique," The International Journal of African Historical Studies 31, no. 3 (1998): 595-625.

166 Galli, Peoples' Spaces, 32-35.

167 Ibid.

168 In Niassa, chehe (Arabic: shaykh) is used to refer to a leader of a mosque.

169 The German military engagement in northern Mozambique lasted from 1914 to 1918, when they were forced out. See also Liesegang, História do Niassa. Currently, in the oral history of the areas where I was working, these wars or attacks were remembered as very short-lived and without significant casualties. 
$\because$ Taylor \& Francis Taylor \& Francis Group http://taylorandfrancis.com 


\section{Part I}

\section{Talking freedom}

\section{The Need for Emancipation}

The emancipation of women is not an act of charity, the result of a humanitarian or compassionate attitude.

The liberation of women is a fundamental necessity for the Revolution, the guarantee of its continuity and the precondition for its victory.

The main objective of the Revolution is to destroy the system of exploitation and build a new society which releases the potentialities of human beings, reconciling them with labour and with nature. This is the context within which the question of women's emancipation arises.

Generally speaking, women are the most oppressed, humiliated and exploited beings in society. A woman is even exploited by a man who is himself exploited, beaten by the man who is lacerated by the palmatoria, humiliated by the man who is crushed under the boot of the boss and the settler.

How can the Revolution triumph without the liberation of women? Will it be possible to get rid of the system of exploitation while keeping one part of the society exploited?

One cannot only partially wipe out exploitation and oppression, one cannot tear up only half the weeds without even stronger ones spreading out from the half that has survived.

How then can one make a revolution without mobilizing women? If more than half of the exploited and oppressed people consist of women, how can they be left on the fringe of the struggle?

To make a revolution it is necessary to mobilize all the exploited and oppressed, and consequently women as well.

If it is to be victorious, the Revolution must eliminate the whole system of exploitation and oppression, liberating all the exploited and oppressed. Therefore it must eliminate the exploitation and oppression of women, it is forced to liberate women. ${ }^{1}$

The neo-Marxist philosopher Henri Lefebvre maintains that for social change to occur, "a group must designate itself as an innovator or producer of meaning." In the case of the Mozambican liberation struggle, one might argue that FRELIMO's nationalist discourse opened a new political space in this sense, providing what feminist philosopher Johanna Oksala calls a "rearticulation of the intersubjective horizon of meanings." 3 This new political language also created 
space for gendered bodies to be reconceptualized and enacted differently. In northern Niassa, FRELIMO's discourse on "women's liberation" called on young girls and women to embrace a new kind of female collective identity and social position. ${ }^{4}$ In this study, I explore the relationship between FRELIMO's nationalist discourse and the female bodies that it sought to represent and mobilize. I focus especially on how this new discourse resonated with the female combatants who as "women" now became defined as "the most oppressed, humiliated and exploited beings in society." To what extent did the women recognize themselves in this new nationalist category of the to-be liberated "Mozambican woman"? The quote that introduces this chapter is taken from Samora Machel's much-cited opening speech at the First Conference of the Organization of Mozambican Women (Organização da Mulher Moçambicana; OMM) in 1973. Over forty years have passed since his famous speech. What is its relevance today? What do women ex-combatants in Niassa remember of this wartime gender discourse? How do they interpret its meaning based on their now extensive life experiences?

Part I of this book concerns the intimate relationship between the body, memory, and history writing. I study how history is continuously remade as the past is reinterpreted in the changing present. Mozambican historiography is a case in point, and it is interesting to analyze how the history of the liberation struggle, and especially the role of women in it, has changed through the years. In the 1970s and 1980s, Frelimo's socialist paradigm had substantial support in left-leaning academic circles, which influenced much of the early research on the liberation struggle, both inside and outside of Mozambique. ${ }^{5}$ As Carlos Fernardes argues, historians felt the need to write a "usable past" that would be supportive of Frelimo's nation-building project and its goal of constructing a socialist society. ${ }^{6}$ Importantly, this history was also supposed to serve as a counternarrative to the colonial history and anthropological accounts of Mozambique in which Africans were attributed no historical agency. ${ }^{7}$ At the same time, the new historiography contributed to the legitimization of what historian João Paulo Borges Coelho calls the "Liberation Script" - that is, Frelimo's teleological narrative of the victory of the Revolution over colonialism, socialism over capitalist exploitation, the new society over the old. ${ }^{8}$ Also, the history of FRELIMO's gender politics and discourse on "women's liberation" became fixed within this teleological narrative frame. ${ }^{9}$ This early body of research adopted and reproduced FRELIMO's language and concepts, such as "traditional society" and "women's oppression" without critically analyzing the meanings and histories of these constructs. Even feminist scholars who have importantly contributed to a more critical study of FRELIMO's theory and practice of "women's liberation" during the war have often tied the meaning of "woman" to a unilinear narrative of "liberation" in which the liberation struggle marks the beginning of a history of emancipatory transformation. ${ }^{10}$ This narrative has undoubtedly played an important role in legitimating and creating space for the women's movement in Mozambique. ${ }^{11}$ But I suggest that it has also limited the exploration of the gendered experiences of the women who 
participated in the struggle as their histories have been tied to the narrative of "women's emancipation."12

My research takes as its focus the life histories of female ex-combatants who are now in their late 50s, 60s, and early 70s. Already, forty years have passed since the end of the liberation struggle. Significant social and political changes have happened in Mozambique during the life times of these women. The temporal distance from the liberation struggle gives people another kind of perspective on the past. One's spatial situatedness, moreover, intimately shapes one's memories. As I will show, the memory of the liberation struggle is quite differently negotiated in the capital Maputo and the communities of northern Mozambique. Thus exploring the life histories of female ex-combatants in Niassa can further contribute to a more complex understanding of women's experience of the liberation struggle and the ways it has shaped the gendered life trajectories of its "protagonists." It can also help us understand how the ex-combatants' life experiences after independence continue to shape their memories of the past. When history is approached this way through the notion of "remembering," it assumes a less linear shape. Here, I emphasize the performativity of memory - that is, the active acts of interpretation by which past experiences are continuously made sense of in the present. ${ }^{13}$ My interviews with the women ex-combatants can be best analyzed as instances of "conversational remembering." As David Middleton and Derek Edwards claim, in conversational remembering, the participants together "articulate the grounds and criteria for what is remembered." ${ }^{4}$ This approach allows us to explore the sociality of remembering in the interview situations and the ways that the meanings of past experiences are negotiated between its participants.

Chapter 1 consists of three subchapters. The first subchapter, "FRELIMO's discourse on 'Women," traces the development of FRELIMO's discourse on gender equality during the wartime and examines how the nationalist category of "Mozambican woman" was used to mobilize young girls and women to participate in the political-military struggle. The second subchapter, "Remembering the "Mozambican Woman,", then moves into a closer analysis of the female ex-combatants' personal memories of FRELIMO's talk about "women" during the war. Through a membership categorization analysis (MCA), I show how the identity categories of the nationalist discourse are constituted-but also resisted and creatively transformed - in the DFs' interview talk. Finally, in the last subchapter, “Gendered Vocabularies of Nationalism,' I turn to look at how the female ex-combatants evaluate the significance of the wartime nationalist gender politics from today's standpoint and how place and other categories of difference become relevant in its interpretation.

\section{Notes}

1 Samora Machel, "The Liberation of Women is a Fundamental Necessity for the Revolution," in Mozambique: Sowing the Seeds of Revolution, ed. Samora Machel (Harare: Zimbabwe Publishing House, 1981), 20. 
2 Henri Lefebvre, Rhythmanalysis: Space, Time and Everyday Life, trans. Stuart Eldon and Gerald Moore (New York: Continuum, [1992] 2004), 14.

3 Johanna Oksala, "Female Freedom: Can the Lived Body be Emancipated?" in Feminist Interpretations of Maurice Merleau-Ponty, eds. Dorothea Olkowski and Gail Weiss (University Park, PA: Pennsylvania State University Press, 2006), 226.

4 Cynthia Cockburn writes that "women" when "invoked like a collective social actor" is an imagined community, and much like the "nation," it can take various forms. Cynthia Cockburn, The Space between Us: Negotiating Gender and National Identities in Conflict (London: Zed Books, 1998), 44.

5 Especially the Oficina de História created in 1980 at the Centre of African Studies (CEA) at Eduardo Mondlane University (UEM) focused on the history of the armed struggle. From 1980-1986, it published research reports as well as four issues of the history magazine Não Vamos Esquecer.

6 Carlos Fernardes, "History Writing and State Legitimisation in Postcolonial Mozambique: The Case of the History Workshop, Centre for African Studies, 1980-1986," Kronos 39, no. 1 (2013): 137. The notion "usable past" comes from B. Jewsievicki (1989).

7 Ibid., 145.

8 João Paulo Borges Coelho, "Politics and Contemporary History in Mozambique: A Set of Epistemological Notes," Kronos 39, no. 1 (2013): 20-31. See also Aquino de Bragança and Jacques Depelchin, "From the Idealization of Frelimo to the Understanding of the Recent History of Mozambique," African Journal of Political Economy 1, no. 1 (1986): 162-180.

9 The studies focusing especially on women: Barbara Isaacman and June Stephen, $A$ mulher moçambicana no processo de libertação (Maputo: Instituto Nacional do Livro e do Disco, 1982); Stephanie Urdang, And Still They Dance: Women, War and the Struggle for Change in Mozambique (New York: Monthly Review Press, 1989); Sonia Kruks and Ben Wisner, "The State, the Party and the Female Peasantry in Mozambique," Journal of Southern African Studies 11, no. 1 (1984): 106-127; Casimiro, "Transformação nas relaçoes." Other research on the liberation struggle that briefly speaks about women: Allen Isaacman and Barbara Isaacman, Mozambique: From Colonialism to Revolution, 1900-1982 (Boulder, CO: Westview Press, 1983); Joseph Hanlon, Mozambique: The Revolution Under Fire (London: Zed Book, 1984).

10 For example, Signe Arnfred, "Women in Mozambique: Gender Struggle and Gender Politics," Review of African Political Economy 15, no. 40 (1988): 5-16; Isabel Maria Casimiro, "Samora Machel e as relações de género," Estudos Moçambicanos, 21 (Maputo: UEM, 2005), 55-84; Isabel Maria Casimiro, "Repensando as relações entre mulher e homem no tempo de Samora," in Samora: Homem do povo, ed. António Sopa (Maputo: Maguezo, 2001), 127-135; Arthur, "Women in the Armed Struggle"; Kathleen Sheldon, "Women and Revolution in Mozambique: A Luta Continua," in Women and Revolution in Africa, Asia and the New World, ed. Mary Ann Tetreault (Columbia: University of South Carolina, 1994), 33-55. See also Kathleen Sheldon and Isabel P. B. Fêo Rodrigues, "Outras Vozes: Women's Writings in Lusophone Africa," African and Asian Studies 7 (2008): 423-445. Moreover, Alice Dinerman argues that the "myth of revolutionary rupture" has persistently shaped the writing of postindependence history. Alice Dinerman, Revolution, Counter-Revolution and Revisionism in Postcolonial Africa: The Case of Mozambique, 1975-1994 (London: Routledge, 2006), 35.

11 For example, Isabel Maria Casimiro, 'Paz na terra, guerra em casa': feminismo e organizações de mulheres em Moçambique (Maputo: Promédia, 2004); Jennifer Leigh Disney, Women's Activism and Feminist Agency in Mozambique and Nicaragua (Philadelphia: Temple University Press, 2008).

12 See also Paulo Israel, "Lingundumbwe: Feminist Masquerades and Women's Liberation, Nangade, Mueda, Muidumbe, 1950s-2005,” Kronos 39 (2013): 204-229. Studying the history of the lingundumbwe dance (invented by a group of Makonde DFs in Cabo 
Delgado after the war), Israel shows how it breaks the linear temporality of "Marxist narrative of feminine oppression."

13 See, e.g., Alessandro Portelli, The Death of Luigi Trastulli and other Stories: Form and Meaning in Oral History (Albany, NY: State University of New York, 1991); Paul Ricœur, Memory, History, Forgetting, trans. Kathleen Blamey and David Pellauer (London: The University of Chicago Press, 2004); Michael Bamberg, "Biographic-Narrative Research, Quo Vadis? A Critical Review of 'Big Stories' from the Perspective of 'Small Stories,'” in Narrative, Memory and Knowledge: Representations, Aesthetics and Contexts, eds. Kate Milnes et al. (Huddersfield, UK: University of Huddersfield Press, 2006), 63-79.

14 David Middleton and Derek Edwards, "Conversational Remembering: A Social Psychological Approach," in Collective Remembering, eds. Middleton and Edwards (London: Sage Publications, 1990), 29. 
$\because$ Taylor \& Francis Taylor \& Francis Group http://taylorandfrancis.com 


\section{FRELIMO nationalism, female bodies, and the language of gender}

\section{FRELIMO's discourse on "women"}

MARIA AJABA: This war-it isn't only for . . . us men that are COLONIZED. Also for you it's worse. For you it's double: the settler is colonizing you, the man also is colonizing you. The man can go together with you to the FIELD, when you return, you with firewood on your head. Hmm? When you arrive there, there is no water. You go to get WATER. The man already sat down. Because he is very tired. His coat-you took the firewood-he is putting on top of your head. That is to colonize. You arrive there ... you arrive there at home ... the man just stays [rests]. You boil water and give to him! You pound [maize] to make flour. The relish is already prepared, you cook chima [thick maize porridge; Ciyaawo: ugadi]for him. You don't REST AT ALL! While the man, when he returned from the machamba - that's it [he's done]. So also you HAVE TO recognize to liberate your body ... of the woman-role of the woman. ${ }^{1}$

CASSIMO DILONDO: They spoke that the women ... they are our women and we will fight together. Those times as the women were being colonized a lot. We used to give them coats to carry. But today we can no longer give coats to the ladies ... because they are the ladies who NO LONGER can be mobilized to carry our coats. It is with them that we will also fight together ... in combat ... to liberate Mozambique from Rovuma to Maputo! And we really obeyed. The ladies now no longer ... THEY AREN'T LADIES. They are our comrades. We suffered together in combat ... we ate together in combat and returned to live at the bases together. This is how they talked. ${ }^{2}$

In the first quote, Maria, who worked as the vice political commissar of FRELIMO's female detachment at the Provincial Base of Ngungunyane in Niassa Ocidental (the western sector of the Niassa war front), ${ }^{3}$ recalls a male political commissar's speech about women's “liberation." According to FRELIMO's rhetoric, women were subject to double oppression: along with men, they were oppressed by colonialism, but, on top of that, they were also oppressed by men in their traditional female roles in society. As Maria narrates in the voice of 
the male commissar: "Also for you it's worse. For you it's double: the settler is colonizing you, the man also is colonizing you." This same political message of women's double oppression echoes in Cassimo Dilondo's account. Cassimo, a stonemason by training, worked as a commander of a base in the Muembe region during wartime. From the male ex-combatants that I interviewed, Cassimo was the one who was most fluent in FRELIMO's discourse about women. While Maria's account asserts the need for women to become conscious of their oppression and thus "subjects of their own liberation," Cassimo's account offers another perspective. It speaks of the supporting role ascribed to men in "women's liberation." The new notion of "women" introduced by FRELIMO was radical in the sense that it called for both men and women to reconceptualize their gendered roles in society and their gendered relationship to each other. As Cassimo narrates, “The ladies now no longer ... THEY AREN'T LADIES. They are our comrades." FRELIMO's discourse challenged prevailing cultural notions of masculinity and femininity and their acceptable performance in and across male and female bodies. Both Cassimo and Maria reproduce a similar description of women's oppression in "traditional society." This narrative tells of a woman returning from the field with her husband. While she walks carrying a stack of firewood on her head, he walks freely, unburdened by baggage. He has even given his coat to his wife to carry. As this commonly told narrative continues, when the pair get home, the woman immediately starts to prepare a bath for the husband and to cook his dinner. Again, the husband makes no move to help his wife but takes the time to relax his tired body. This short story captures the main idea in FRELIMO's socialist analysis of women's position in "traditional society." It was repeated to me numerous times over the interviews I conducted among ex-combatants in Niassa. However, as I will explore in more detail later, these reenactments by both Maria and Cassimo also point to the distance between this discourse and the people's lived experiences.

Cynthia Enloe argues that in nationalist movements, women have often been told to wait with their claims for equality in relation to men until after the liberation struggles. ${ }^{5}$ According to Casimiro, FRELIMO was one of the few liberation movements on the African continent in the 1960s and 1970s that insisted that "women's liberation" should be dealt with during the armed struggle. ${ }^{6}$ For instance, Samora Machel's speech at the OMM Conference in 1973 (see page 41) clearly establishes a "unity of purpose"7 between "women's liberation" and "national liberation." Yet this discourse on "women's liberation" - that these days shapes many ex-combatants' understanding of the role of women in the struggle-only developed gradually in the war. It is clear that in the beginning, the FRELIMO leadership did not have a definite idea of what kind of role to assign to women. Moreover, the leadership in Dar es Salaam disagreed strongly over the nature of the struggle and the desired shape of society after independence. In Mozambican historiography, this has predominately been described as a conflict between two factions: the socialist group, which defined the struggle as a war against Portuguese capitalism and colonialism, and the second group, which wanted to liberate Mozambique 
for the black Mozambicans. ${ }^{8}$ The question of women's participation in the struggle was also differently viewed by these factions. Those in the socialist camp viewed women's participation more favorably; they linked class oppression to gender oppression and thus recognized the distinct nature of "women's oppression." "The conflict between these two groups escalated in the crises of 1968-1969 and culminated in the assassination of Eduardo Mondlane, the first president of FRELIMO, in 1969. Though the "woman question" continued to be a contentious issue within the leadership throughout the first half of the war, it is important to note that already from the very beginning, FRELIMO expressed a commitment to integrate women into the struggle. ${ }^{10}$ Soon after the creation of FRELIMO, in 1962, the Liga Feminina Moçambicana (the League of Mozambican Women, LIFEMO) was established. Its leading figures mainly involved wives of FRELIMO leaders residing in Dar es Salaam at the time, such as Celina Simango. Closely affiliated with FRELIMO, the objective of LIFEMO was to support the families that joined FRELIMO and to explain to them its political agenda. ${ }^{11}$ As Samora Machel retrospectively argued in 1973, at the time when LIFEMO operated, FRELIMO did not yet have a clear idea of "women's liberation." ${ }^{2}$ In FRELIMO's own historiography, LIFEMO's role has been strongly discredited. According to FRELIMO, LIFEMO politics and activities were out of touch with Mozambican realities; moreover, Machel criticized LIFEMO for operating too independently from FRELIMO. ${ }^{13}$ In 1969, LIFEMO was fused with the DF. ${ }^{14}$ Although a critical history of LIFEMO still awaits to be written, one can argue that its fate was closely intertwined with the power struggle within the FRELIMO elite over whose vision of nationalism would prevail.

The DF was officially created by the decree of the Central Committee in October 1966. As the DF leaders from Cabo Delgado that I interviewed in Maputo argue, it was only through women's active engagement in military activities that FRELIMO was forced to make the decision to allow women's full participation in the guerrilla forces. ${ }^{15}$ In 1967, a platoon of twenty-five girls from Cabo Delgado became the first female group to receive politicalmilitary training in Nachingwea. After their six-month training was complete, they were followed by a group of girls from Niassa. Also in Niassa, like in Cabo Delgado, girls and women were participating in military activities before the creation of the DF. ${ }^{16}$ According to Ndegue, the Central Base of Mbembe in Niassa Ocidental received its first group of girls in $1965 .{ }^{17}$ My interviews with ex-combatants also indicate that the FRELIMO guerrillas were recruiting girls since the early days that military mobilization began in Niassa. ${ }^{18}$ One of these young female recruits was Amélia Omar, who was enlisted in 1965. According to Amélia, the soldiers who came to her village mobilized the youth in this manner:

"In this war there are no women, there are no men. All of us have to fight." Because when we said it is only for men. [The soldiers responded:] "No! It is for all of us. ANYONE who wants, enters."19 
Although at the time both boys and girls were recruited, there was yet no pronounced discourse on "women's liberation." Girls were mostly recruited to help politically mobilize the population to support FRELIMO in the armed struggle. Toward the end of 1965, female recruits in Niassa were gathered into femaleonly bases where they received some rudimentary training on how to defend themselves. ${ }^{20}$ It appears that at this time, FRELIMO did not fully know what to do with these girls. Officially, the role of women in the army was formalized with the creation of the DF in 1966. Curiously, according to ex-military commander of Niassa Oriental ${ }^{1}$ Eduardo (Ntoto) Nihia (1966-1969), the military command in Niassa received official orders to start recruiting women only in 1967. ${ }^{22}$ Nihia, however, admits that in Niassa, they were recruiting girls before this, even though it was actually "illegal." ${ }^{23}$ From the beginning of the 1970s, the group inside FRELIMO leadership that supported a revolutionary line assumed control of the party, and the struggle became framed more strongly within a socialist discourse. ${ }^{24}$ It was only around this time that "women's liberation" became an integral part of the political education of the guerrillas. ${ }^{25}$

FRELIMO's nationalism-historian and political scientist Michel Cahen points out - was not the nationalism of a social movement; instead, it was produced by a small southern-born assimilado elite. ${ }^{26} \mathrm{He}$ also suggests that the Marxism that FRELIMO adopted had a "tendency towards eurocentrism." 27 In FRELIMO's gender politics, there is also indication of this bias. One can argue that FRELIMO's gender analysis of society and especially of women's “oppression" was based on the elites' own experience and educational background and failed to sufficiently reflect the diverse experiences of the people it claimed to represent. Most importantly for my discussion, FRELIMO's nationalist discourse introduced a completely new concept of "gender equality" that built on an idea of a dichotomous relationship between men and women. ${ }^{28}$ This was at odds with how gender identity was conceptualized in the rural societies of northern Mozambique. According to Arnfred, in the north of the country, gender identity was understood through "ideas of complementarity between men and women." 29 FRELIMO's socialist analysis, however, did not include an examination of the matrilineal north but drew mainly on the elites' own experience of the patrilineal societies of southern Mozambique. One example of this is FRELIMO's analysis of the traditional institution of marriage and lobolo (bridewealth payment from the groom to the family of the wife-to-be). According to FRELIMO, lobolo was an oppressive practice that established the husband as the owner of his wife. While this also provides a simplified understanding of the gendered dynamics and social organization of the communities of southern Mozambique, it completely distorts the idea of the marriage institution in the north of the country. As I will discuss in more detail later, marriage and family were differently conceptualized in the matrilineal Yaawo societies. ${ }^{30}$ However, in FRELIMO's discourse, "traditional society" only had one shape and function-and it had to be destroyed so that a "new society" could take its place. Women were also called to participate in this fight against "tradition" and to "liberate" themselves in the process. ${ }^{31}$ 
In FRELIMO's socialist rhetoric, "women" was construed as the most oppressed social category. According to FRELIMO, the capitalist system intertwined with traditional society was exploiting women and reducing them to passive objects of male desire and enslavement. What was needed, it argued, was a radical transformation of women's gendered self-conceptualization. This, as FRELIMO claimed, could be achieved through women's participation in the struggle in equal partnership with men. This meant that men also had an important role to play in "women's emancipation." As exemplified in Maria's and Cassimo's accounts in the beginning of this chapter, while women were educated to take their space next to men, men were taught to recognize women's new position as their comrades-in-arms. FRELIMO explicitly argued that the struggle for "women's liberation" should be understood as a class struggle. It did not recognize women to have specific gender interests. As Machel warned in his 1973 speech, "there was to be no antagonism" between men and women. ${ }^{32}$ In FRELIMO nationalism, the only interests allowed expression were those of "the people."

FRELIMO's nationalism made no commitment to pluralism; instead, it fought against cultural expressions of difference. After all, in FRELIMO rhetoric, the "tribe" had to die for the nation to be born. ${ }^{33}$ As Cravinho writes, FRELIMO understood diversity as a disruptive force that threatened to jeopardize "unity." 34 While not everyone subscribed to FRELIMO's vision of "national unity," challengers were often violently silenced. ${ }^{35}$ Many of these contesting voices have later been obscured by FRELIMO's history writing. FRELIMO even faced criticism that its idea of "women's liberation" was something imposed on the women by FRELIMO and did not resonate with the women's own experiences of their cultural roles in society. ${ }^{36}$ Still, drawing on Marxist theory, FRELIMO insisted that the exploitative society had impressed on the women a sense of false consciousness that prevented them from understanding their own oppression. Here, a notion of revolutionary experience is central to understanding FRELIMO's nationalist discourse. As FRELIMO claimed, through engaging in the revolutionary struggle, women would learn the meaning of "liberation." All women could not, however, join the DF to gain this emancipatory experience, as they were not all suited for military training. OMM was created in 1973 - with DFs as its founding members - to engage the wider female population in the struggle. The DF constituted the central core of the women's organization; ${ }^{37}$ they had, after all, paved the way for women's participation in the liberation struggle. As the DFs had already gained revolutionary experience through their military engagement in the struggle, they were considered the driving force in the struggle for women's liberation.

It was through the practical experience of living the new ideals that female and male combatants were supposed to make personal sense of an otherwise abstract discourse. Also, as Maria's and Cassimo's accounts at the beginning of this chapter show, the political commissars tried through simplified stories to bring FRELIMO's politics closer to the experiences of the people. Both men and women were subjected to this political education. In the following 
interview segment, a male ex-combatant Tito Brás Cassimo speaks of his memories:

TITO: So it was the work of the commissar. (...) So it was them that mobilized the DF. For what? That they could be sensitized to know/understand that we are Mozambican women ... that ... WE can have any job. There are no [separate jobs] for man. There are no [separate jobs] for woman. As we are all people, we are equal. What the man does, the woman also has to do. What the woman does, the man also has to do. So this is what [the commissar] spoke during the liberation struggle.

JONNA: Also to the men? Not only to the women? Hehe.

TITO: [Overlapping speech] Yes. [Continues with laughter in his voice:] No. Hehe. Because they did everything . . . They managed . . . to go to combat. Right? TO SHOOT with a weapon for real, to shoot. That was the work of the man, but she also ... took the weapon.... She managed to look for honey there [in the bush]. Do you know how to extract honey? JONNA: Huh-huh, no.

TITO: No? IN THE TREES.

JONNA: Aah. Yes, yes.

TITO: There where the bees enter. So they managed to extract those honeycombs ... that ... thing of the bee. So for us to manage what? To eat ... the honey. They managed to extract, also these people [managed to do

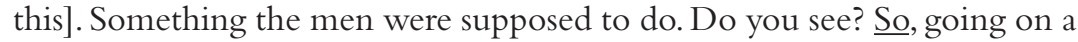
march for a few days, any journey, we are-we arrive in a place where we have to cook. This one ... she is doing, I don't know what, washing plates. Another, the man, is washing the pot. The man is getting firewood. He is here, he is putting the pot on the fire. Right? Everything. Another does this, does that, but everything for ... in the same place. Yes. So this is what they [the women] did, just like the male comrades, they also did the same tasks. There wasn't any distinction, yah. ${ }^{38}$

Marie José Arthur argues that FRELIMO's "no men and no women" discourse was inherently male biased and only contributed to the "masculinization" of women. ${ }^{39}$ However, I suggest (and I will analyze this in more detail later) that the political education on "gender equality" together with the practice of working together challenged prevailing cultural notions of masculinity and femininity and their acceptable performance in and across male and female bodies. In his speech, Tito emphasizes the fact that during the war, men were also doing previously female-coded jobs, such as collecting firewood, cooking, and cleaning dishes. He also speaks of how women managed to go to combat, take up weapons, and collect honey. At the time, these were defined as male tasks in society. Of course, the army still remained a patriarchal institution where all important decisions were made by male leaders. But ex-combatants' accounts of their memories show that these new notions of gender equality did not remain completely abstract but became part of their lived realities in the military camps. Experiences between different women and men vary, of course; 
also, camp life depended greatly on the specific commander and political commissar in charge. There were also many bases where only men worked-for instance, bases of advance. Also, officers received more vigorous political education than regular cadres. Thus experiences varied, which also reflects in the ex-combatants' narratives.

I also asked Tito whether women and men have gone back to performing the same gender-defined jobs as before the war. He explains like this:

Right, now that only happens in our houses now. Because we are dispersed, we are not in the barracks. Hmm. Because when we were in the barracks ... everything we did together, right? But when we are here in our houses, everyone is ... in their own place, right? Each one knows how they are living ... there in their house. But WHO got used to that, does [accordingly]. And also if they were to marry ... DF with ... with ... I mean, a member of the female detachment with a member of the male detachment ... it seems ... the jobs would be the same ones from the bush. [Continue with light laughter in his voice:] Because they still haven't lost the memory ... of helping one another. Because mutual help is what we knew. Only now we are mixed. I marry a civilian. This one here marries a- a civilian. The ideas then are different. What the man WANTS isn't ... the same as ... what the woman wants. She does the contrary. Or despite what the woman wants, the man does the opposite. Isn't it? So it is difficult to fulfil ... the same function. It's difficult. So each one knows how-how must I be with this one here that doesn't know this. If the person doesn't want to comply with that, I have to do, I have to comply according to my knowledge, yah. It's how we live now. Hehe. ${ }^{40}$

Tito argues that civilians and ex-combatants have different experiences and thus a different understanding of how to divide the tasks at home. He even suggests that in the case where two ex-combatants are married, they share their work the same way as they did in the mato. However, as I visited the houses of male and female ex-combatants in Niassa, they all appeared to have conformed to the gendered organization of labor that prevails in the communities in which they live. The same way that ten years is a short period in which to create a sense of national identity, as Cahen argues, ${ }^{41}$ it is also a very short time to significantly change the gendered dynamics of society. Gender subversion is not, as Butler insists, "a singular act, but a repetition and ritual" over an extended period of time. ${ }^{42}$ Wars, especially revolutionary wars, are usually exceptional periods of social change. ${ }^{43}$ Whether these social changes become more permanent depends on the gender politics of the state-building period. Maxine Molyneux writes that the feminist observers who were excited by the prospects of "women's liberation" so strongly advocated in the socialist struggles of the time period were sorely disappointed by the lack of concern for women's issues after independence. ${ }^{44}$ Often, the revolutionary periods have been followed by more conservative gender politics in peacetime. Also, Frelimo's gender discourse on "women's liberation" became less pronounced after independence. As Signe 


\section{Talking freedom}

Arnfred writes, in 1976, at OMM's second conference, the "classic socialist theories of women's emancipation" became the guideline for Frelimo's gender politics. ${ }^{45}$ This meant that a gender analysis of social relations, which had been part of the discourse during the liberation struggle, became increasingly unimportant. With FRELIMO's transformation into a Marxist-Leninist vanguard party in 1977, its discourse also changed to emphasize the oppressive "social order." FRELIMO prescribed that women would become full and equal members of the "new society" through their engagement with men in new social relations of production as wage workers on state farms or cooperatives. Feminist scholars argue that this analysis completely ignored women's productive labor in the family sphere, for instance, on family farms. Historian Kathleen Sheldon writes that Frelimo focused on women's practical interests (e.g., through childcare programs and health service) but largely ignored "strategic issues of gender equality." 46 After independence, the animosity of the Frelimo leadership toward what it defined as "traditional" also became more articulate. At the Second Conference of OMM in 1976, Frelimo waged war on a long list of issues it argued women needed to address (e.g., initiation rites, lobolo, superstition, divorce, tribalism, and regionalism).${ }^{47}$ Moreover, as "an arm of the party," OMM was allowed no autonomy to conduct its own gender analysis but had to follow the political line of Frelimo. ${ }^{48}$ Despite talk on the importance of women's political mobilization, women were given very few leadership positions inside Frelimo. This meant that the male leaders of Frelimo largely controlled the official discourse on the position of women in the new socialist society.

\section{Remembering the "Mozambican Woman"}

After independence, Frelimo's history of the armed struggle became construed as the national history of Mozambique. As the protagonists of the struggle, the ex-military leaders through their testimonies played a crucial role in shaping the narrative construction of the Frelimo nation. These narratives, as historian Amélia Neves de Souta writes, "were, at this time, carefully coordinated and presented a single, uniform and homogenous narrative." ${ }^{\prime 9}$ Coelho refers to this as the "Liberation Script." 50 As he argues, this "script" was effective due to its "simplicity" that "was assured in particular by its linear unfolding on the basis of binary oppositions." " If one did not support Frelimo, one was labeled "reactionary" and an enemy of the nation. Thus by producing its grand narrative of "national liberation," Frelimo also claimed ownership over the definition of the "Mozambican nation." Cahen even uses the notion of "party-nation" to highlight the fact that Mozambican nationalism was a project orchestrated by the Frelimo party. ${ }^{52}$ The Frelimo narrative aimed to build a unified "we experience" that silenced any contradicting individual experiences of the armed struggle. ${ }^{53}$ Even the voices of rank-and-file ex-combatants were marginalized. Those male ex-combatants who took positions in the new government in Maputo and other urban areas became its privileged narrators. For instance, Casimiro, who contributed to the Oficina de História (History Workshop) at CEA, recalls how 
in the 1980s when she conducted her research on the participation of women in the armed struggle, the vast majority of the female ex-combatants in Maputo adamantly declined to be interviewed. Both state censorship (state-imposed silence) and associated self-censorship made the narration of certain memories impossible. Only the changes in the political and social environment in the late 1980s began to open space for new voices and different kinds of interpretations of national history. ${ }^{54}$ In the 1990 s, male ex-military leaders started publishing books on their own memories of their participation in the "patriotic" war. ${ }^{55}$ Most of these publications have been careful not to break with the "liberation script" and have not offered any radical reinterpretations of history. Still (often unintentionally), these publications have contributed to the destabilization of the inner cohesion of the Frelimo narrative. Coelho writes that by turning what had so far only existed in oral form into written narrative, the Frelimo history lost what had been its great strength: its flexibility and adaptability to the changing political circumstances. ${ }^{56}$ Now, discrepancies and contradictions between the personal narratives of the ex-combatants have become more discernible. Sometimes these personal narratives even question the way that certain events have been told in official history. ${ }^{57}$ Most importantly, they show that different memories of the liberation struggle do continue to coexist, even if they have had limited space for expression in the public sphere.

The voices of women ex-combatants have been notably absent from these historical testimonies. ${ }^{58}$ However, in 2012, a project headed by the former secretary-general of OMM Paulina Mateus N'kunda (a former guerrilla fighter herself) and coordinated by historian Benigna Zimba produced a publication on women's participation in the liberation struggle. ${ }^{59}$ In this book, which largely reproduces the Frelimo narrative of "women's liberation," DF leaders are allocated space to give their testimonies. At the same time, most of the lower-ranking DFs are listed by name only. Claiming women's space as indispensable historical actors alongside men, the book importantly writes women into the male-dominated Frelimo history. Yet as books are expensive and do not circulate well in Mozambique, none of the women I interviewed in Niassa were aware that such a book had even appeared. Moreover, even despite the growing number of publications, many rank-and-file ex-combatants still seem concerned about their right to take part in the telling of the history of the liberation struggle. ${ }^{60}$ The legacy of Frelimo's totalitarian culture still lingers in collective memory. Ex-combatants in Niassa, however, were noticeably less concerned with following the official Frelimo narrative than the ex-combatants I interviewed in Maputo. Still, in order to conduct my research, I had to assure the ex-combatants that ACLLN, a Frelimo organization, had "authorized" the interviews. So while I approached the DFs to tell me their personal life histories (and not an event history of the liberation struggle), they seemed to acknowledge that these narratives could never entirely belong to the individual.

In this subchapter, I mainly focus on my interviews with a female ex-combatant called Maria Mota, born in Litunde in Majune. When the guerrillas first showed up in her home area, they mobilized her to help carry maize flour to 
the FRELIMO base. Yet before long, she was recruited to join the guerrillas, and she trained in Nachingwea in 1967 with the first group of women from Niassa. Maria was one of my most eager interviewees. As she told me, she was very pleased that finally someone had come to write about the history of the DF in Niassa and about her life as part of that history. As she describes,

We only heard that the historians will come, the historians will come-not knowing what year they will come. And here I was wondering ... waiting and hoping [in the sense of moralizing] for the year that they will come. Now that they did, yaah, the heart is content, ah. I don't know, if we will live, we will see [the book]. If we won't be alive, the children will see. ${ }^{61}$

In Maputo, "women's liberation" is a narrative very strongly produced in the life history accounts of female ex-combatants. Thus in the beginning of my research in Niassa, I assumed that DFs there would also prove fluent narrators of this "grand narrative of the Mozambican woman" 62 and that they would take ownership of this nationalist identity category. However, I discovered this not to be the case. Rather, the conversations that Helena and I had with many of the DFs regarding the topic were not easy to make immediate sense of except for the fact that many women had difficulty remembering this supposedly important discourse. I thus chose to conduct a MCA $^{63}$ of the interview segments dealing with the topic for the purpose of making better sense of these conversations and meaning-making processes. The main idea of MCA is to look at how membership categoriesthat is, social identity categories (in my case "woman," "ex-combatant," and "DF")—are used and negotiated in talk-in-interaction, such as that of the interviews. This involves looking at how these categories are ascribed meaning through attaching certain attributes (such as personal traits, preferences, and dispositions) and activities to them. In what follows, I examine how the interviewees negotiate their relation (the relation of self) to the notion of "woman" constructed in the nationalist discourse. Thus through a microlevel analysis of selected interview extracts, I show how cultural gender categories are "constituted, experienced, resisted and transformed" 64 in the DFs' interview talk.

In the following interview segment, Helena and I attempt to elicit remembering of wartime talk about the role of women in the struggle from Maria.

HELENA: Nkukumbucila caaka ca watandite kuweceta cipepa ca acim'maryeto ... mun'gondo ja kuwombola cilaambo?

MARIA: Yaaka ni nganayimanyiyaaka ni nganayimanyidila. Yaaka-ya ngacimanyidila digongo uwe wane wangaryoma, eeh.
HELENA: Do you remember when they started to talk about the role of women ... in the war of liberating the country?

MARIA: The dates I won't knowthe dates I won't know. The date I won't know because we others we didn't study, yes. 
HELENA: Nambo mundanda pemo ou ... parikati? ... Pakuraka rano kuradicirya ya acim'maryeto . . . akumenyana. Cici akumenyanila acim'maryeto? Kuti citende cici?

JONNA: Foi na Base Beira, Tunduru, Nachingwea? . . O Ou eles nunca falaram? Hehe.

MARIA: Wune nguti ngayikumbucila eti kala-kala kekala. Hmm.

Helena: Aah. Pele-po eti.

MARIA: Mmm.

HELENA: Yele ya acim'maryeto nganawecetaga?

MARIA: Wa?

HELENA: Ni yele eti yakuwurya.

MARIA: Aah.

JONNA: Da mulher moçambicana também?

MARIA: Aah! Mulher ... mulher, aah. Hehe.

HELENA: [Overlapping speech]

Nganimpikanganaga nayo pakuti nditeje ya cipepa.

MARIA: Ehee [affirmation], hehe (XXX). HELENA: [Overlapping speech]

Cipepa ngati malowe-go.

MARIA: Pacaaka ya-pacaaka cawidi cajile ni kupitila nono jakwe ... data jakwe eti ngajimanyidila. Tudi tuterile-tuwurile kuNacingweya katema katutanditeHELENA: Kupikanicirya yicindu-yila. MARIA: [Overlapping speech] kupikanicirya. Kupikanicirya ya acim'maryeto . . . digongo dya cici ... tukumenyana ...
HELENA: But there in the very beginning or ... in the middle? ... Now when they wanted to explain about the women ... they are fighting. Why are the women fighting? To do/accomplish what?

JONNA: Was it at Base Beira, Tunduru, Nachingwea? Or they never talked? Hehe.

MARIA: I said I don't remember because that was a long time ago. Hmm.

HELENA: Aah. Yeah, it was.

MARIA: Mmm.

HELENA: This about women they didn't talk?

MARIA: Who?

HELENA: Because that's what is being asked.

MARIA: Aah.

JONNA: Of the Mozambican woman also?

MARIA: Aah! Woman ... woman, aah. Hehe.

HELENA: [Overlapping speech] You didn't understand because I was speaking about the role.

MARIA: Ehee [affirmation], hehe (XXX). HELENA: [Overlapping speech] "Role" because of these words.

MARIA: The year-the second year that passed ... the date I don't know. When we had donereturned from Nachingwea was the time we started-

HELENA: To understand those things. MARIA: [Overlapping speech] $\underline{\text { To }}$ understand. To understand about women ... because of what ... are we fighting ... ${ }^{65}$

What might first appear to be a rather trivial moment of stumbling communication, I suggest, involves important remembering and categorization work. Interviews, as Carolyn Baker argues, are sites of joint meaning making and coconstitution of social categories. ${ }^{66}$ In the short interview exchange noted earlier, the category of woman is repeatedly evoked, yet its meaning can be shown 
to be in the process of constant negotiation. To begin with, the first interview question introduces "woman" as an assumedly relevant category in its connection to the liberation struggle, and through the question, "Do you remember when?," the interviewee Maria is invited to construct a link between her personal firsthand experience and this categorization. The exchange that follows, however, problematizes the idea of "woman" as the most readily available category in relating to the remembering of one's war experience. First, Maria, insisting that she doesn't know "because we others we didn't study," makes a claim to the relevance of an alternative category linked to another social variable: educational background. Helena's clarifying question, however, challenges this self-categorization as an acceptable excuse and denies its relevance to our exchange. The expected correct answer does not require the knowledge of exact dates, the knowledge of an educated person. ${ }^{67}$ Moreover, throughout the discussion, Helena's persistent questioning and unwillingness to accept "I don't know" or "I don't remember" as correct answers (also ignoring my suggestive question that perhaps the role of women was never talked about) effectively constructs Maria as someone with an expected "relationship of ownership" 68 to the knowledge of the role of women in the struggle.

Continuing in her attempt to elicit an answer from Maria, Helena further links the categorization of "woman" with the activity of fighting, thus evoking the category of the woman fighter. However, formulated in a form of a question through the interrogative word "why," it emphasizes an unusual relationship between the two. But even despite these additional clarifications and Helena's provocative question formulation, Maria displays defiance in her response. "I said I don't remember because that was a long time ago," she insists. Here she refers solely to her individual subjective experience, and Helena's immediate affirmative response, "Aah. Yeah, it was," ratifies Maria's answer as acceptable. Through this small show of empathy, Helena, furthermore, ties her personal experiences with Maria's, marking shared interpersonal knowledge. Meanwhile, the categories "woman" and "woman fighter" still remain elusive, meaningless general categories in this exchange, not effectively linked to the personal experience of the participants. This is made evident by Helena's question, "This about women they didn't talk?" and Maria's subsequent question, "Who?" Maria still treats Helena's question as puzzling asking for further clarification. Only when a new spatial attribute "Mozambican" is introduced in connection to the category "woman" does Maria express full recognition of our attempted categorization work. At this point, Helena-hearably quite thrilled by our final success - quickly moves to blame the term "cipepa" 69 ("role" in English) for the initial confusion and Maria's "forgetfulness." Knowing this vocabulary (be it direct translations of Portuguese terms commonly used in the public speeches commemorating women's war participation) is constructed as an attribute morally unconnected to the category of the female fighter, and thus Maria's position as its competent member is restored. ${ }^{70}$

In the interviews, many women appeared to reenforce the idea that as DFs, they are rightfully assumed to be linked to knowledge about the wartime gender discourse and its category of woman. Yet many women (like Maria) expressed 
the difficulty of remembering. "That was a long time ago," it was often argued. Also, the normal human condition of "forgetting other things" was emphasized. This points to the distance of the discourse - as well as the political arenas in which its memory continues to be produced-from the women's life spaces and experiences these days. For instance, Rosa Salimu, who lamenting the fact that she has difficulties remembering the details of her war experience, argues that it is easy for Helena since she is "still part of the structure." By this she means that Helena is still actively involved with the Frelimo party. After all, the party is an important site for building collective memories. Out of the DFs I interviewed, only a handful claimed to have no memory of the war talk about women. But even in these cases, no one argued that these issues had never been spoken about or that they themselves had never heard about them. A lack of "knowledge" was also not admitted. Only the passage of time was apologetically blamed for one's forgetfulness. Remembering (as well as forgetting), ${ }^{71}$ as Edwards and Middleton point out, is an inherently social activity, ${ }^{72}$ and as I will attempt to show, it is also linked to the category bound duties and moral obligations of the category of "DF."

In their accounts, the women spoke of how throughout the war as soldiers they had received political lessons on the objective of the war on a routine and repetitive basis. ${ }^{73}$ Yet political education relating to the role of women in the struggle was introduced a few years into the war. Thus most of the female recruits had not been initially mobilized as "women" to engage in war activities. In the following extract (continuation from the first extract), Maria discusses her memories of how the role of women in the struggle was explained during the war.

MARIA: Kupikanicirya. Kupikanicirya ya acim'maryeto ... digongo dya cici ... tukumenyana. Ni twapikaniciryaga ya pele-po kuti "Aah, ana nombe apa kwana wakulungwa roni ni wam'maryeto? Mpaka ya kuturadila roni na ayiyi?" Ni wawecetaga yele-yo kuti amu mwanyamwe amunoamuno cilaambo-ci cetu ... tukamuryane na acalume-wa. Tutende ngondo tutameje ntendele. Eeh, wawecetaga wele mayi-wo. Eeh. Kwadi ni iyoyo kwadi . . . ya kuraka kuwumbola.

HELENA: Essa coisa, essa coisa de falar sobre a mulher, nós começamos a ouvir depois de voltar de Nachingwea, é que começou falar aquilo aí.
MARIA: To understand. To understand about women ... because of what ... are we fighting. We understood there that "Aah, after all, here there exists even a female leader? Even informing us this?" And she was saying that you [second-person plural] right here in this our country ... [together] with these men we must help each other. We have to make war for us to be at peace/independent/ free. Yes, that mother [a term of respect] there spoke. Yes. I don't know if it is that, I don't know ... only this of wanting to liberate.

HELENA: This thing, this thing of talking about the woman, we started to hear after returning from Nachingwea, that is when they 
Vinha outra mulher assim. Então estava a falar, dizer que "vocês têm que lutar, tem que trabalhar como homem. É para libertar o nosso país! A mulher também tem direito ... de trabalhar! ... A MULHER tem direito de fazer todas atividades." Ya, nós dissemos "ahahah, afinal, mulher também ... PODE CONSEGUIR A FORÇA DO HOMEM." Sim.

MARIA: Twatandite kupikanicirya digongo ngati kutikuti ...tuwaleje buluku worepe, malaja, kacikweti, bota. Rano pa tukuripata tukwiona kuti "wi iyee, wakongwe ni walume jiweje yimpepe." $\mathrm{Ni}$ pa twandite kupikanacirya kuti "aah-iih."

HELENA: Mmm. É aí onde estava receber também fardamentos explicou também que agora vamos pôr-Vocês hoje vão receber esse fardamento. Vocês têm que lutar. Assim vão treinar, aprender tudo. Está aqui botas, está aqui calças, está aqui camisa. Está chapéu. MULHER deve usar como homem. Mulher deve trabalhar como homem... Aí é onde que começámos já ... receber as aulas da coisa da mulher. Ah, afinal, a mulher também tem direito. $\mathrm{Hmm}$. started saying that there. Another woman, like this, came. So she was talking, saying that "you have to fight, you have to work like men. It is to liberate our country! The woman also has the right ... to work! ... The WOMAN has the right to do all activities." Ya, we said that "ahahah, after all, the woman also ... CAN OBTAIN THE STRENGTH OF THE MAN." Yes.

MARIA: We started to understand because when they were saying ... we will all wear trousers, shirts, berets, boots. Now when we are receiving, we are seeing/ experiencing that "yes, women and man have to be the same/ equal." It is when we started to understand that "aah-iih."

HELENA: Mmm. It was there when we were also receiving uniforms, they explained also that now we will put-You today will receive this uniform. You [women] have to fight. Like this you will train, learn everything. Here are boots, here are trousers, here is a shirt. A beret. The WOMAN has to dress like the man. The woman must work like the man. . . It is there that we started already ... to receive lessons about the woman. $\mathrm{Ah}$, after all, the woman also has the right. $\mathrm{Hmm}^{74}$

The introductory statement at the beginning of this sequence, "to understand about women ... because of what ... are we fighting," constructs "woman" as a category of collective membership, which also includes the speaker. This positioning of oneself, as I suggest, is prerequisite to the remembering that proceeds. In the first instance, the reenactment of a surprised realization, " $\underline{\text { Aah }}$, after all, here there exists even a female leader?" emphasizes the noncommonsensical linking of the gender category "woman" with the professional category "military leader." The following exclamation-"Even informing us this?"furthermore conveys the experience of surprise that still marks the memory of 
being confronted by her very existence (later, she is also referred to through the respectful familiar term "mother") but also this woman's act of speaking, and, moreover, the content of her talk. The remembered speech "you right here in this our country ... [together] with these men we must help each other" first addresses the women fighters through the general personal pronoun "you" (in the second-person plural) but then through "we" calls them to engage in collective action. Importantly, the spatial construct "right here in this our country" is made to operate as a link between the gender differentiated domains. The act of bringing "men" and "women" together to engage in the activities of war is, moreover, subjugated to the moral discourse of national liberation and national unity. Also, as Maria in her last comment in this conversation turn concludes (after expressing uncertainty of whether she has in fact managed to produce the kind of knowledge that this interview requires of her) to emphasize "only this of wanting to liberate" as the most unambiguous point for her.

In her Portuguese explication of Maria's response in Ciyaawo, Helena, drawing on her own experiences, emphasizes how women through political education were informed of their "right" to do activities that had previously been constitutive of the gendered male domain. And, in addition, how the collective "we" (referring to women) realized that their bodies were capable of achieving that which commonsensically had been conceived of as a masculine attribute of physical strength. ${ }^{75}$ Moreover, in her translation of Maria's answer, Helena-by adding her own interpretative layers of meaning to it - transforms Maria's account into an evocation of a common experience that they supposedly both share. Taking over from her, Maria-perhaps inspired by Helena's interpretation - then continues to elaborate how "we" (the women) came to make sense of this gender discourse and women's new capabilities, which involved the incorporation of "masculine activities" into "women's" categorybound activities. Maria constructs the experience of witnessing ("seeing/ experiencing") women wearing exactly the same military clothes as men-the forceful blurring of the recognizability of female versus male bodies ("women and men have to be the same/equal") — as the moment when the political discourse started making actual sense to her.

Later in the interview (after first discussing the identity of these female superiors), Helena and I question Maria further about her personal experience of hearing these female leaders speak.

HELENA: So at the time when those there were talking, Deolinda with Paulina Mateus, how did you see/feel in your heart and how did it enter into your head that "kwe [expression of admiration], these women are speaking like this about WOMEN."

MARIA: Hehehe. At the time we said that "ey, this country has now changed, even women are standing in front of other women informing/instructing them."76

This small exchange further exemplifies the situated joint remembering and categorization work in which both participants are engaged. Helena's exclamatory question - with its loaded emphasis on the word "woman" and the evocation 
of the "intimate space" 77 of the sensing body-through the personal spatial referents of "your heart" and "your head," preconstructs the to-be-remembered event as emotional, personal, and extraordinary. In her response, however, Maria, speaking again in the first-person plural, merges her experience to that of the collective "we." Moreover, this "we," constructed through her remembering, evokes an idea of a particular collective female experience of the struggle. Though based on the individual experiences, in the interviews, remembering is often constructed as a collectively performed activity, while forgetting is conceived of as a lonely singular experience. In the next subchapter, we will look further into how the female ex-combatants evaluate the significance of the wartime nationalist gender politics from today's standpoint and how place and other categories of difference become relevant in its interpretation.

\section{Gendered vocabularies of nationalism}

Drawing on my research material, FRELIMO's gender rhetoric is best exemplified in the political slogan "there are no men, there are no women," which was often repeated in the women's accounts of wartime political education about the role of women in the struggle. In my interviews, I found this common language phrase to be a useful probe in generating discussion on the meaning and significance of the nationalistic gender discourse for the women these days. The notion of "women's liberation/emancipation" was rarely acknowledged in the women's interview accounts. ${ }^{78}$ In this subchapter, I focus especially on Maria's and Helena Caisse's interviews, which express very different emotional undertones and positionings in relation to the nationalist discourse. In the first excerpt, we continue our interview talk with Maria (the excerpt is taken from the end of the third interview).

HELENA: Pa mwadiji mun'gondo, macefi genu watendaga mirongano kunradila kuti ajingondo-ji jangadi walume jangadi wakongwe; worepe tumenyaneje. Jele pulitikajo-kwadini nkwiwona rampano jino? Mun'gondo ni jele-jo jadiji ni jakombolece ni jikombolece. Nambi rampano jino jele politikajo jikwete ... akuti cici? . . JIKWETE citukuko ... diriku dya leelo jino? Mun'gondo jakwete citukuko nambo leelo jino jikwete citukuko? $\mathrm{Na}$ nkujiwona jana citukuko mpaka rano, kwaradila. $\mathrm{Na}$ nkujiwona ja-jimarile rano, KWANGADI! Mwaradile.
HELENA: When you were in the war, your superiors organized meetings and told you that this here war doesn't have men, doesn't have women; we all have to fight. That politics there-I don't know, do you see it now? In the war that there was possible, it was possible. But now what does that politics have? DOES it have progress . . . these days? In the war it had progress but today does it have progress? If you see it has progress even today, explain to her. If you see that it ended, now it DOESN'T HAVE! Tell/ explain to her. 
MARIA: Yana citukuko ngati . . ngayikulekangana marengo: acakongwe, acalume akurewera. Jana citukuko. Hmm.

HELENA: Disse até agora vale essa política. Porque nas empresas antigamente não havia mulher, mas agora trabalham homens e mulheres. Sim.

JONNA: Aah. Então o significado desta política é isso?

HELENA: Rano, mana ga jele pulitikajo ni jele eti?

MARIA: Eeh eti. Hehe. Ni jele-jo.

Eti wakongwe rano akwenderya motoka . . . wakongwe, eeheeh, buluku kuwala. Marengo gagadi gore wakongw-Aku walume, apa wakongwe. Yorepe tukwiwona yidi cenene. Mmm, hehe.

HELENA: Porque agora mulher . . . pode comprar uma calça, pôr. [MARIA: ehe!] Está andar livre. Mulher ... pode pegar carro, conduzir. Mulher apanha no gabinete com aqueles computadores a bater-aqui homem, aqui mulher. Então VALE.
MARIA: It has progress because . . . there is no difference in the work: women and men are working. There is progress. Hmm.

HELENA: She said that until now that politics is valid. Because in the workplaces back in the days there weren't any women, but now men and women work. Yes.

JONNA: Aah. So that is the meaning of this politics?

HELENA: So the objective/meaning of that there politics is this, isn't it?

MARIA: Yes, yeah. Hehe, that's it. Yeah, the woman now drives a car ... yes, the woman wears trousers. All kinds of jobs the woman-There a man, here a woman. Everything that we see is good. Mmm, hehe.

HELENA: Because now women ... can buy trousers, put them on. [MARIA: Yes!]. She is moving freely. Woman ... can take a car, drive. You can find woman in the office with those computers typing-here a man, here a woman. So it's VALID. ${ }^{79}$

In her first question formulation - an imaginative translation of my interview question, which again draws on her personal experience-Helena ties the FRELIMO gender rhetoric tightly to the wartime and the collective "we" defined through the collective activity and duty of fighting ("this here war doesn't have men, doesn't have women; we all have to fight"). Helena suggests that during the war, this "politics" was a lived reality, yet she also implies that today this politics no longer holds transformative value. Maria, despite Helena's orientation, does not align herself with this projection. "It has progress," she argues instead. Maria's account also exemplifies a commonly expressed perception about the current "value" of the nationalist gender politics; as it is argued, its continued importance is epitomized in women's integration into paid labor with men. According to FRELIMO, women's "liberation" would come through their engagement in "production" on equal footing with men. However, what is curious, in most of the DFs' accounts and visible in Maria's account, is the lack of self-reference. For instance, here, Maria no longer speaks in the first-person plural "we," but the "woman"-who has a job outside the 


\section{Talking freedom}

home, who drives cars, who wears trousers - and thus embodies the progress of the gender discourse, is distanced from her personal life experiences. The collective "we," in her account, is only evoked as an outside observer ("everything that we see is good").

In the second excerpt, we discuss with another ex-combatant Helena Caisse the meanings and values she attaches to the political notion "there are no men, there are no women." Helena trained in Nachingwea in the second group in 1968 and served at Base Katur in Niassa Austral (the southern sector of the Niassa military front).$^{80}$ Prior to this excerpt, we have already gone through a lengthy and quite animated discussion about the meaning and significance of "politics," which Helena C. views more negatively than Maria.

HELENA: Rano wele akuwidirya roni pala-pala: Digongo wele-wo amburirye kuti ... anaga pulitika . . . jadiji cici? M'mwe ni ntite: "Aah! Politika [bursts in laughter with Helena C. joining her] yindu yawunami." [Helena and Helena C. continue laughing together.] Rano wune roni ngumbwidirya kumburya kuti rano yele-yo yawatiga-yo kuti ngapagwa walume ngapagwa wakongwe-nombe NAYO YADIJI YAWUNAMI?

HELENA C.: Aah, eti yawonekaga. Yele nganiyiwa yawunami. Worepe tuwe acalume. Wakongwe kuwala buluku ni malaja ni cikopya ni wuti. Yele ni yawonekaga. Wele ngawa wunami. Ngati ni kuuwa yimo-yimo na acalume. Eeh.

HELENA: Disse ESSE Aí, no tempo de GUERRA, era verdade. Diziam que vamos trabalhar homem e mulher. Aquilo aconteceu! Porque homem ... estava fardado, com arma dele, iam no combate juntos. A MULHER também assim mesmo. O mesmo fardamento, mesma arma, combate juntos. Aquilo ấ ... valia.

JONNA: Mas hoje em dia?
HELENA: Now this one [referring to me] is still repeating the same: Because this one asked that ... after all, politics ... was what? You said: "Aah! Politics [bursts into laughter with Helena C. joining her] is a thing of lies." [Helena and Helena C. continue laughing together.] Now I am again repeating, asking you that now, that there, what they said: that there are no men, there are no women-also THOSE WERE LIES?

HELENA C.: Aah, yeah, it happened. That wasn't a lie. We'll all be men. The woman wearing trou$\underline{\text { sers }}$ with a shirt and beret, with weapon. That happened. That there isn't a lie. Because we are the same as/equal with the men. Yes.

HELENA: She said that there, in the time of WAR, it was true. They said that we'll work, men and women. That happened! Because man ... he was in uniform, with his weapon. They went to combat together. The WOMAN also the same way. The same uniform, the same weapon, going to combat together. That there ... was real. JONNA: But today? 
HELENA: Mas hoje em dia,É MENTIRA! JONNA: Hoje em dia é mentira? Pode explicar? Hehe.

HELENA: Rano leelo jino pa kuuwa, $\underline{\text { aah, }}$ pulitika yawunami. Cici ca nciweni kuti mmwe acicaci wunami?

HeLENA C.: Pulitika ya wunami.

HELENA: Hehehe [laughs loudly]. HELENA C.: [Laughs as she speaks:] Pulitika ya yawunami n'yimanyi. $\mathrm{Ni}$ yele ya nguwalanga. Macefi gagadi akuno-kuno gala gore pe gala. Wawutwice-wuwutwice ku-Maputu nduuu, akuno kutuleka uwe. Ana akuja kwira kutulola? Panganawaga wunami?

HELENA: Disse se agora, se política não é mentira, nós estivemos com o nosso comandante ... homens, mulheres. Quando acabou a guerra ... andou ... recolher entre chefes, e foram a Maputo. Montam aí. Nós estamos aqui até hoje a sofrer! Esse não é MENTIRA?! Estava nos enganar para ajudar eles viver bem.
HELENA: But today, IT'S A LIE!

JONnA: Today it's a lie? Can you explain? Hehe.

HELENA: Now today for this, aah, politics to be a lie. What did you see/ experience for you to say that this here is a lie?

HELENA C.: Politics is a lie.

HELENA: Hehehe [laughs loudly].

HELENA C.: [Laughs as she speaks:] Politics is a lie, you know. That's what I am saying. All those leaders that are here ran to Maputo filling up the place, leaving us here. After all, do they return to come and see us? Doesn't it become a lie?

HELENA: She said if now, if politics weren't a lie, we would be with our commander ... men, women. When the war ended ... they went . . . choosing between leaders, and went to Maputo. They set up camp there. We are here until today suffering! Is this not a LIE? They were deceiving us to help them live well. ${ }^{81}$

"Politics are lies," Helena C. impassionedly insists, gathering supportive laughter from Helena. During the months that I spent with the DFs and male ex-combatants in Niassa, I often encountered very critical talk about "those that hadn't really fought" (this included members of the nationalist party elite based in Maputo) but who were reaping most of the material benefits of national independence and development. In many interviews, FRELIMO's wartime nationalist discourse (especially its notions of unity, freedom, and good life) are critically juxtaposed with the women's experiences of a sense of accumulating disappointment with post-Samora (or post-socialist) state politics. Moreover, the category of war veteran is not perceived as a unified category but is divided along spatial, educational, and class lines. As Helena C. points out, after independence, it was the military leaders who received privileged treatment and were sent to the state capital, while the rest (the "we") were left behind in Niassa. "After all, do they return to come and see us?" Helena C. accusingly asks. What is implied here is that it is this sense of isolation that, for her, transforms "politics" into an experience of deception. Moreover, Helena's commentary at the end of this interview excerpt adds another layer of meaning 
to Helena C.'s argument. Constructing a collective experience of continued suffering ("We are here until today suffering!"), ${ }^{82}$ the wartime nationalist politics, with its notions of nationalistic unity and socialist egalitarian way of life, is reinterpreted as deceit, based instead on its antithesis, a relation of economic exploitation.

Curiously, Helena C. seems to evaluate FRELIMO's gender politics from a slightly different perspective. "Aah, yeah, it happened. That wasn't a lie," she responds when Helena challengingly questions whether "also THOSE WERE LIES?" Moreover, in this sequence, the notion that "there are no men, there are no women" introduced by the interview question is discarded and replaced by "we'll all be men." While the former evokes an idea of "androgynous warriorhood" 83 through the degendering of the combatant category, the latter constructs the category of combatant as exclusively male gendered. Moreover, as Helena C.'s account shows, during the war, it was possible for women to become "men." By engaging in the activities of wearing the army uniform and using the weapon, women could become members of this male gendered collectivity. As Deborah Rubin argues, conceptualizations of gender are closely linked to cultural rules about labor. ${ }^{84}$ Marie José Arthur argues that the wartime slogan of "no men and no women" means that everyone was to be "considered as men" and thus the precondition for "women's liberation" was their "masculinization." ${ }^{85}$ Based on my research, however, I suggest a different kind of interpretation. I think it is important to note that in the different interview accounts, the collective membership category of the combatant (the soldier) is gendered in a variety of ways, many times also inside one individual person's account. Sometimes it is even constructed as a female gendered collectivity that encompasses both male and female bodies. In Teresa Macotoa's account, women (as well as men) are simultaneously gendered male and female. As she recalls the commissar saying to the DFs, "You women there, you are men and women. Also, we are men and women. We will wage a war that doesn't have men, doesn't have women." ${ }^{86}$ These examples point to a certain fluidity and ambiguity of the gender categories during the war period as they became linked to the category of the soldier and a variety of new activities and attributes.

The experienced failure of state politics these days, though causing critical reinterpretations of the wartime nationalist politics, has no seeming negative effect on the memory of gender politics and women's gendered participation in the struggle. As Helena C. concludes, "That happened. That there isn't a lie. Because we are the same as/equal with the men. Yes." This is echoed in the accounts of many other DFs. Often, this is referred to as a concluded action. When asked to reflect on her present experience, Helena C. goes back to stating that "politics are lies," which as I earlier showed is linked to a more general understanding of politics that dismisses gender as a relevant category of difference. Women ex-combatants seldom speak in terms of "women's interests"; 87 rather, they argue that their interests are aligned to those of their male colleagues in Niassa. This echoes Frelimo's discourse, which stated that women should not see men as their enemies. Moreover, during the war, FRELIMO 
argued that women's liberation was tied to national independence. Thus many women interpret that "women's emancipation" was achieved with independence. It would appear that these days, though women's participation in the war with men is remembered as a meaningful event, the significance of the once revolutionary gender politics lies more in the past (the pastness of the past) -in the concluded act of national liberation - than closely connected to the women ex-combatants' present life spaces and struggles.

Kevin McSorley writes that war should be understood as "politics incarnate, politics written on and experienced through the thinking, feeling bodies of men and women." ${ }^{88}$ In revolutionary wars, this is even more pronounced. For Frelimo, fighting was the politics; fighting was part of a political process. ${ }^{89}$ Many ex-combatants remember nationalist politics as the "lived politics" of the wartime. In the struggle, nationalist ideology, together with its gender ideals, was repeatedly inscribed on the soldiers' bodies through both discursive and material practices. Here, I emphasize Bronwyn Davies's definition of the concept of inscription as a "text written on the deep/surfaces of the body/ landscape, not in the sense of scarifying but in the sense of bringing the subject into being." ${ }^{\prime 90}$ For female soldiers, the revolutionary practice of becoming politically conscious also involved becoming aware of one's category bound oppression as "women." As Maria Ajaba's (a vice political commissar during the struggle) quote on page 47 exemplifies: "So also you HAVE TO recognize to liberate your body . . . of the woman — role of the woman." Maria's words also demonstrate how, as Casimiro has suggested, in FRELIMO's politics of "women's liberation," men and women were simultaneously constructed as both the to-be-transformed subjects and the transformative agents of revolutionary politics. ${ }^{91}$ It is also important to note that during the struggle, the political mobilization of the population and of fellow soldiers was one of the most important tasks of the DF. Gender politics, as the interview accounts show, however, failed to receive major attention in its own right, but was promoted only insofar as it served the general objectives of national liberation. Still, some new ways of conceptualizing cultural gender categories were introduced; and as I suggest, this new knowledge about gender was not only construed through political discourse but also through the experiences of living and enacting these political ideas.

Along with the notion of lived politics, I also emphasize the sociality of remembering. This necessarily recognizes that individual embodied memory and social memory are interrelated. In Part I, I have focused especially on "conversational remembering" and how remembering in the interview situation is an interactive and, in this sense, a collective engagement, "a remembering together," by which the meanings of past events are renegotiated and sometimes outright contested. It is only in the face-to-face intersubjective "we-relationship," as Alfred Schutz insists, that "I" can ask "you" for your interpretations of your life experiences. ${ }^{92}$ The place of remembering, moreover, plays an important role in the social construction of memory. Separated by up to $2,000 \mathrm{~km}$ from the state capital, the "remote" location of the northern province of Niassa in terms of 
national geography both allows for and incites more critical renderings of the memory of national liberation. In the interview accounts, this spatial distance is often narrated as isolating, an experience of separation from the nationalist elite and one's former military commanders. This points to the importance of the official institutional settings and commemorational ceremonies in constituting sites of "remembering together" and thus aiding to build a sense of belonging to the national ex-combatant collectivity. Still, the ex-combatant collective "we" is not constituted only through the practice of "remembering together," but in recollecting past "we relationships," distant others (also those who have already passed away) — to employ Paul Ricœur's language — are drawn near and made linguistically present. ${ }^{93}$ Remembering the liberation struggle, closely tied to reinventing a common "we experience," is thus also an enactment of social membership in the ex-combatant collectivity. On rare occasions, the collective "we experience" of women ex-combatants is also recollected, especially through the remembering of FRELIMO's "female politics"; however, unlike "ex-combatant," "woman" no longer acts as a significant category of political and social mobilization.

It is also questionable to what extent "ex-combatant" acts as a unifying category. While the ex-combatants in Niassa seek to narrate their inclusion in the "national" ex-combatant collectivity, they also narrate their difference and separation from this community. Their narratives show how this community is divided along lines of social class and geographical location. They strongly criticize the fact that their interests are not represented by the state. In Niassa, it is not uncommon for people, also ex-combatants, to refer to Maputo as the "nation." " José Luís Cabaço argues that in people's minds, the "nation" thus becomes equated with the state and the government. ${ }^{95}$ Maputo is perceived as the center of command, the location where all the major decisions about the country are made. These are then implemented in the provinces and the districts. This reflects people's experience of the hierarchy of spatial relations; Maputo is the location of central state power, and the rest of the country follows its lead. This hierarchy is also reflected in the telling of the history of the liberation struggle. The ex-combatant leaders and Frelimo party officials in Maputo claim control of the grand narrative of liberation. Yet as the excombatant narratives in Niassa show, this control does not completely hold. Rather, the Frelimo narrative changes shape as it is repeated across the different landscapes of Mozambique. This is especially evident in the nationalist narrative of "women's emancipation." OMM as the organization of Frelimo women has been instrumental in promoting this narrative. Moreover, the leading figures of DF in Maputo have played a significant role in shaping this grand narrative of the "Mozambican woman." 96 After independence, many female ex-combatants, especially in Maputo, continued as active members of OMM. These days, although OMM is present in Niassa, it does not have a very visible or influential presence. Even Helena, an honorary founding member of OMM, argues that she sometimes finds it "difficult to work with the civilians at OMM." This is probably an important part of the reason why the "women's 
narrative" of the liberation struggle has so little emphasis in Niassa. Moreover, many of the women ex-combatants are not experienced tellers of their war memories. While the neat and cohesive narratives of women ex-combatants I interviewed in Maputo suggest that they have been repeated numerous times and have thus achieved a more fixed form; the narratives I heard in Niassa were more fragmented and contained many inner contradictions. These conversational narratives, as I have shown, illustrate how remembering involves an ongoing negotiation over the meaning of past experiences. The women's negotiations over the nationalist notion of "women," moreover, show how the gendered body cannot be reduced to discourse. ${ }^{97}$ FRELIMO's nationalism (despite its analytical limitations) undeniably opened new political space during the wartime to reconceptualize gender relations. Moreover, the female combatant bodies were not passive surfaces upon which these politics were written. And while I agree with feminist philosopher Johanna Oksala when she argues that only "creative politics" can "rearticulate the terms of a body's cultural constitution," 98 I also insist that the creativity of bodies needs to be acknowledged and studied more closely. As another philosopher, Erin Manning, argues, "Without a commitment to the ways in which bodies move, bodies become stabilized within national imaginaries in preordained categories, such as citizen, refugee, man, woman, homed, homeless." 99 Through the chapters that follow, I will thus continue to explore how bodies creatively negotiate and make their own spatiality within the context of the different and competing cultural narratives and material practices.

\section{Notes}

1 Interview with Maria Ajaba, Lichinga, August 18, 2013.

2 Cassimo Dilondo in a group interview with male ex-combatants in Muembe district, June 14, 2013.

3 The western sector encompassed the areas of Lago, Sanga, the municipality of Lichinga and the district of Lichinga. The sectorial and provincial command had joint headquarters located in the district of Lago. Ndegue, $A$ luta de libertação.

4 Casimiro, "Repensando," 133.

5 Enloe, Bananas, Beaches and Bases.

6 Casimiro, "Repensando," 128; Casimiro, "Paz na terra." Compare with Norma Kriger, Zimbabwe's Guerrilla War: Peasant Voices (Cambridge: Cambridge University Press, 1991), 191-196. Kriger argues that in the liberation struggle in Zimbabwe, racial equality was privileged over gender equality.

7 Maxine Molyneux, "Mobilization without Emancipation? Women's Interests, State, and Revolution," in Transition and Development: Problems of Third World Socialism, eds. Richard R. Fagen et al. (New York: Monthly Review Press, 1986), 295.

8 See also, e.g., Sheldon, Pounders of Grain, 118; Coelho, "Politics and Contemporary History," 21-22. The fight between two factions within the FRELIMO leadership is part of FRELIMO's official history of the liberation struggle. See Frelimo, História da FRELIMO (Maputo: FRELIMO, 1981), 17-21. In more recent years, historians have started to argue that the political struggle within the leadership was not as clear-cut as FRELIMO wanted the people to think. See, e.g., Benedito Luís Machava, "The Morality of Revolution: Urban Cleanup Campaigns, Reeducation Camps" (PhD diss., University of Michigan, 2018); Meneses, "Xiconhoca, o Inimigo"; Georgi Derluguian, "The Social 
Origins of Good and Bad Governance: Re-interpreting the 1968 Schism in Frelimo," in Sure Road? Nationalisms in Angola, Guinea-Bissau and Mozambique, ed. Eric MorierGenoud (Leiden: Brill, 2012), 79-101.

9 See also Molyneux, "Mobilization without Emancipation?"

10 One of its first resolutions in 1962 was "to promote by all methods the social and cultural development of the Mozambican woman." Quoted in Sheldon, Pounders of Grain, 119. See also Eduardo Mondlane, The Struggle for Mozambique (Middlesex: Penguin Books, 1969), 122, 147-148, 186-187.

11 Casimiro, "Paz na terra," 173.

12 See Machel, "Liberation of Women," 21-22.

13 Machel, "Liberation of Women"; see also Casimiro, "Samora Machel e as relações de género."

14 Josina Machel, “The Role of Women in the Struggle," Mozambique Revolution 41 (1969): 24-27.

15 See Katto, "Landscapes of Belonging."

16 See also "23 Mozambican Girls Participate in the Armed Struggle," Mozambican Revolution 21 (September 1965): 7.

17 Ndegue, A luta de libertação.

18 See also testimonies in Organização da Mulher Moçambicana (OMM) and Benigna Zimba, A mulher moçambicana na luta de libertação nacional: memórias do destacamento feminino (Maputo: CPHLLN, 2012).

19 Interview with Amélia Omar, Lichinga, November 30, 2012.

20 In Niassa Ocidental, Base Chityale was created for women. According to my interviewees, there were "more than a hundred" girls at the base. Women's bases in Niassa Oriental included at least Base Ngaselo (in the proximity of N'sawisi, by the Lujenda river); Base Katembe (after N'sawisi in the direction of Mecula); and Base Lutyambila, which was for DFs with children (by the Rovuma River). The female-only Base of Chityale in Niassa Ocidental was attacked by Portuguese troops in the beginning of 1966, and the women were moved to the Central Base of Mipoche. In Niassa Ocidental, no female-only bases existed after this, and women were no longer separated from men. In Niassa Oriental, some female-only bases continued throughout the war. Although after Base Katembe was destroyed by Kaúlza de Arriaga, most DFs worked at mixed bases. Niassa Austral never had female-only bases.

21 The eastern sector included the areas of Mavago, Mwembe, Mecula, Majune, Marrupa, Maúa, and Metarica. Its headquarters were located in Mavago by the river N'tiringwe. Ndegue, A luta de libertação.

22 Interview with Eduardo Silva Nihia, Maputo, July 2, 2014.

23 Eduardo Nihia quoted in Raimundo, "Frente do Niassa," 519. Yet he continues to argue that FRELIMO was not actually actively recruiting women, but just receiving girls that the parents were bringing to the base in order to protect them from the Portuguese troops.

24 The nationalist elite was pragmatic in its adoption of socialism. FRELIMO's socialist ideology evolved through the years and combined elements from both Chinese and Soviet models. See John S. Saul, A Difficult Road: The Transition to Socialism in Mozambique (New York: Monthly Review Press, 1985); Thomas Henriksen, "Marxism and Mozambique," African Affairs 77, 309 (1978): 441-462; Yussuf Adam, "Trick or Treat: The Relationship Between Destabilisation, Aid and Government Development Policies in Mozambique 1975-1990" (PhD diss., Roskilde Universitet, 1996). See also Machava, “The Morality of Revolution," who emphasizes the influence of Maoism on FRELIMO's ideology and military strategy. Early scholarship was sympathetic of what it understood to be a genuine socialist program and consciousness. Later scholarship has been more critical. See, e.g., Coelho, "Politics and Contemporary History"; Dinerman, Revolution, CounterRevolution and Revisionism; M. Anne Pitcher, Transforming Mozambique: The Politics of Privatization, 1975-2000 (Cambridge: Cambridge University Press, 2002). Michel Cahen even argues that socialism was only a tool for the elite to advance its nation-building 
goals. See Michel Cahen, "Anticolonialism \& Nationalism: Deconstructing Synonymy, Investigating Historical Process," in Sure Road? Nationalisms in Angola, Guinea-Bissau and Mozambique, ed. Eric Morier-Genoud (Leiden: Brill, 2012), 1-30.

25 FRELIMO's gender politics became more formalized between 1969 and 1972. See Isaacman and Isaacman, "Role of Women in the Liberation"; Isaacman and Isaacman, Colonialism to Revolution. See also Mondlane, The Struggle; Machel, "Role of Women." Josina Machel's text exemplifies this emerging gender discourse. In its full-fledged form, this discourse is perceivable in Samora Machel's speech at the opening session of the First Conference of OMM in 1973.

26 Cahen, "Anticolonialism \& Nationalism."

27 Ibid., 3.

28 See also Hilary Owen, Mother Africa, Father Marx: Women's Writings of Mozambique 1948-2002 (Lewisburg: Bucknell University Press, 2007).

29 Arnfred, "Women in Mozambique," 9.

30 Lobolo is not generally practiced among the Ayaawo. See also, e.g., Alexandre António and Lúcia Laurentina Omar, Alguns usos e costumes matrimoniais dos povos Yao e Nyanja da provincia do Niassa (Lichinga: CIEDEMA, 2007).

31 This is also exemplified in Josina Machel's text from 1969. See Machel, "Role of Women." See also "First Conference of Mozambican Women," Mozambique Revolution 54 (1973): 23.

32 A similar discourse is evident in "Defining Women's Enemy," a speech by Samora Machel at a women's meeting in 1976 in Maputo. In Samora Machel: An African Revolutionary: Selected Speeches and Writings, ed. Barry Munslow (London: Zed Books, 1985), 169-178.

33 For example, Samora Machel, "Educate Man to Win the War, Create a New Society and Develop our Country," in Mozambique: Sowing the Seeds of Revolution, ed. Samora Machel (Harare: Zimbabwe Publishing House, 1981), 35. This speech by Samora Machel was given in September 1970.

34 J. T. G. Cravinho, "Modernizing Mozambique: Frelimo Ideology and the Frelimo State" (PhD thesis, University of Oxford, 1995), 58. See also Meneses, "Xiconhoca, o Inimigo."

35 See, e.g., Barnabé Ncomo, Uria Simango: Um Homem, Uma Causa (Maputo: Edições Novafrica, 2003).

36 Machel acknowledges this in his 1973 speech.

37 Despite this, as Casimiro argues, the creation of OMM was not uncritically accepted by all DFs. Some women argued that the DF was already performing the task of mobilizing and working with civilian women in the liberated areas, thus they questioned the necessity of a new organization. Casimiro, "Paz na terra," 175.

38 Interview with Tito Brás Cassimo, Lichinga, June 19, 2014.

39 Arthur, "Women in the Armed Struggle."

40 Interview with Tito Brás Cassimo, Lichinga, June 19, 2014.

41 Cahen, "Anticolonialism \& Nationalism," 17.

42 Butler, Gender Trouble, xv.

43 See also Valentine M. Moghadam, "Gender and Revolutions," in Theorizing Revolutions: New Approaches from Across the Disciplines, ed. John Foran (London: Routledge, 1997), 133-162.

44 Molyneux, "Mobilization without Emancipation?"

45 Arnfred, "Women in Mozambique."

46 Kathleen Sheldon, “To Guarantee the Implementation of Women's Emancipation as Defined by the Frelimo Party': The Women's Organization in Mozambique" (Working Paper 206, Michigan State University, May 1990), 7.

47 See also Disney, Women's Activism, 52.

48 Ibid., 54. See also Sheldon, "Implementation of Women's Emancipation."” Also as Cravinho argues, the political structures were mainly concerned with mobilizing people according to Frelimo's agenda. Cravinho, "Modernizing Mozambique," 82. 


\section{Talking freedom}

49 Amélia Neves de Souto, "Memory and Identity in the History of Frelimo: Some Research Themes," Kronos 39, no. 1 (2013): 284.

50 Coelho, "Politics and Contemporary History."

51 Ibid., 23. See also João Paulo Borges Coelho, "Abrir a Fábula: Questões da Política do Passado em Moçambique," Revista Critica de Ciências Sociais 106 (2015), 153-166.

52 Michel Cahen, "Nationalism and Ethnicities: Lessons from Mozambique," in Ethnicity Kills?: The Politics of War, Peace, and Ethnicity in SubSaharan Africa, eds. Einar Braathen, Morten Bøas, and Gjermund Sæther (Basingstoke: Macmillan, 2000), 163-187; Michel Cahen, "Check on Socialism in Mozambique-What Check? What Socialism?" Review of African Political Economy 57 (1993): 46-59.

53 Voices of those unsupportive of its party line were violently silenced. See, e.g., Igreja, "Frelimo's Political Ruling"; Coelho,"Politics and Contemporary History," 22-23; Paulo Israel, "The Formulaic Revolution: Song and the 'Popular Memory' of the Mozambican Liberation Struggle," Cahiers d'Etudes Africaines 1, no. 197 (2010): 181-216.

54 In 1986, academics Aquino de Bragança and Jacques Depelchin wrote what is now considered a seminal paper in which they argued that the history of Frelimo needed to be studied "not an unchangeable text, but as a contradictory process." They insisted on the "analysis of concrete realities." Bragança and Depelchin, "From the Idealization of Frelimo," 164-165.

55 As Amélia Neves de Souta writes, President Armando Guebuza (2005-2015) played a crucial role in "rehabilitating" the memory of the liberation struggle. de Souto, "Memory and Identity." Some of the important places during the liberation struggle were turned into "historical locales" or open-air museums of Frelimo history. They also became sites for commemoration ceremonies on significant dates in Frelimo history.

56 Coelho, "Abrir a Fábula," 157.

57 Coelho, "Abrir a Fábula."

58 Except for the joint book by Marina Manguedye and her husband Raimundo Pachinuapa, $A$ Vida do Casal Pachinuapa (Maputo: JV Editores, 2009).

59 See OMM and Zimba, Mulher Moçambicana na Luta.

60 Liazzat Bonate also speaks of difficulties in interviewing ex-combatants in Pemba in the province of Cabo Delgado in 2007. See Bonate, "Muslim Memories."

61 Interview with Maria Mota, Lichinga, July 4, 2013.

62 Katto, "Landscapes of Belonging."

63 In my use of MCA as an analytical tool, I am especially interested in "the situated and reflexive use of categories" that Elizabeth $\mathrm{H}$. Stokoe argues is the primary focus of MCA and which allows for it to be understood as a separate method from conversation analysis. Elizabeth H. Stokoe, "Gender and Discourse, Gender and Categorization: Current Developments in Language and Gender Research," Qualitative Research in Psychology 1, no. 2 (2004): 111. Moreover, I take membership categories to have no pregiven essentialized meanings, understanding them as being constantly produced in interactional instances. See, e.g., Stephen Hester and Peter Englin, "Membership Categorization Analysis: An Introduction," in Culture in Action: Studies in Membership Categorization Analysis, eds. Stephen Hester and Peter Eglin (Washington, D.C.: University Press of America, 1997), 1-23; Carolyn D. Baker, "Locating Culture in Action: Membership Categorisation in Texts and Talk," in Culture \& Text: Discourse and Methodology in Social Research and Cultural Studies, eds. Alison Lee and Cate Poynton (Oxford: Rowman \& Littlefield Publishers, 2000), 99-113.

64 Stokoe, "Gender and Discourse," 109.

65 Interview with Maria Mota, Lichinga, July 27, 2013.

66 Carolyn D. Baker, "Membership Categorization and Interview Accounts," in Qualitative Research: Theory, Method and Practice, ed. David Silverman (London: Sage, 2004), 162-176.

67 The women generally did not construe their narratives around dates. Some women divided the wartime into three periods: the beginning, middle, and end. Helena often used this system of periodization in her questioning to help us acquire knowledge about 
the temporal framework of a story. Ordinal numbers (e.g. "the second year") were also used to situate events and experiences in wartime.

68 Mariaelena Bartesaghi and Sheryl Perlmutter Bowen, "The Acquisition of Memory by Interview Questioning: Holocaust Re-Membering as Category-Bound Activity," Discourse Studies 11, no. 223 (2009): 222-243.

69 Apparently originally derived from the English word "paper" but used here in the Portuguese sense of the word "papel," which means not only "paper" but also "role."

70 On the duties and moral obligations of the category, see Lena Jayyusi, Categorization and the Moral Order (London: Routledge and Keagan Paul, 1984).

71 Forgetting, through the silencing of certain memories, is a strategy actively employed in remembering. See, e.g., Heidi Gengenbach, "Naming the Past in a 'Scattered' Land: Memory and the Powers of Women's Naming Practices in Southern Mozambique," The International Journal of African Historical Studies 33, no. 3 (2000): 523-542; Luisa Passerini, "Memories between Silence and Oblivion," in Contested Pasts: The Politics of Memory, eds. Katherine Hodgkin and Susannah Radstone (London: Routledge, 2003), 238-254.

72 David Middleton and Derek Edwards, "Introduction," in Collective Remembering, 1-22. See also e.g. Maurice Halbwachs, The Collective Memory, trans. Francis J. Ditter, Jr. and Vida Y. Ditter (New York: Harper \& Row, 1980).

73 For instance, women who participated in the struggle as milicianas did not receive the same kind of political education.

74 Interview with Maria Mota, Lichinga, July 27, 2013.

75 See Jack Halberstam, Female Masculinity (London: Duke University Press, 1998). Halberstam argues for the understanding of masculinity as detached from a naturalized linking to male bodies. See also Amadiume, Male Daughters.

76 Interview with Maria Mota, Lichinga, July 27, 2013.

77 Massey, For Space.

78 Only Amélia Omar and Maria Kambongwe mentioned the Portuguese word "emancipação" (emancipation). Assiato Muemedi, in her interview talk in Ciyaawo, spoke of women's advancement during the struggle. As she narrates, "Because in the past those that were in front were men, women were behind" ("Digongo kala-kala-ko yadiji wa kuuwa mbujo aceni acalume, acakongwe wa panyuma"). Interview with Assiato Muemedi, Mavago, June 25, 2013. According to Helena, during the war,"women's emancipation" was translated as "kupikangana kwa acim'maryeto" ("entendimento de mulheres"). Nowadays, gender equality is commonly translated as "acakongwe na acalume adi wampepe" ("women and men are the same/equal") or "walume na wakongwe akwete cipepa cimo" "“men and women have the same role").

79 Interview with Maria Mota, Lichinga, August 21, 2013.

80 The southern sector covered the districts of Ngaúma, Mandimba, Mecanhelas, Cuamba, and a part of the district of Lichinga. Its headquarters were located in the mountains of Kwisimba. Ndegue, A luta de libertação.

81 Interview with Helena Caisse, Sanga district, July 21, 2013.

82 This experience sets them apart from the nationalist elite who remember "suffering" as a collective experience of the past. See also Cabaço on how the "narration of suffering" was used as a rite of passage during the liberation struggle. José Luís Cabaço, Moçambique: Identidades, Colonialismo e Libertação (Maputo: Marimbique, 2010), 278.

83 Ali Mazrui, "Gandhi, Marx and the Warrior Tradition: Towards Androgynous Liberation," Journal of Asian and African Studies XII, nos. 1-4 (1977): 179-196.

84 Rubin, Deborah S., “'Business Story is Better than Love' Gender, Economic Development, and Nationalist Ideology in Tanzania," in Women Out of Place: The Gender of Agency and the Race of Nationality, ed. Brackette Williams (London: Routledge, 1996), 245-269. On the separation of life into male and female gendered spheres of activity in rural Niassa, see Chapter 2.

85 Arthur, "Women in the Armed Struggle."

86 Interview with Teresa Macotoa, Sanga district, May 27, 2013. 


\section{Talking freedom}

87 This suggests that gender is not the most significant category shaping their interests in relation to the state. See also Molyneux, "Mobilization without Emancipation?" Molyneux argues for us to make note of the difference between "women's interests," "strategic gender interests," and "practical gender interests."

88 Kevin McSorley, "War and the Body," in War and the Body: Militarisation, Practice and Experience, ed. Kevin McSorley (London: Routledge, 2012), 1.

89 See Terence Lyons on the notion of militarized politics. Demilitarizing Politics: Elections on the Uncertain Road to Peace (Boulder, CO: Lynne Reinner, 2005).

90 Davies, (In) scribing, 11.

91 Casimiro, "Repensando," 133.

92 Alfred Schutz, The Phenomenology of the Social World, trans. George Walsh and Frederick Lehnert (Evanston, IL: Northwestern University Press, 1967 [1932]), 167-171.

93 Halbwachs argues that a "body of memories" has continuity only through collective remembering. Halbwachs, Collective Memory.

94 Other researchers have also observed the way that people separate between "the Nation," "the province" and "the district." See Coelho, "Politics and Contemporary History," 24; Cabaço, Moçambique, 299.

95 Cabaço, Moçambique, 299.

96 See, e.g., speeches by Marina Pachinuapa, Deolinda Guezimane and Teresa Tembo in Partido Frelimo, Simpósio 50 anos da Frelimo (1962-2012): fontes para nossa história (Maputo: CPHLLN, 2012).

97 See also Lefebvre, Production of Space, 204.

98 Oksala, "Female Freedom," 226.

99 Erin Manning, Politics of Touch: Sense, Movement, Sovereignty (Minneapolis: University of Minnesota Press, 2007), xv. 


\section{Part II}

\section{Violent liberation}

As I approach the provincial office of ACLLN in Lichinga, I feel slightly nervous. ${ }^{1}$ A lot depends on this first meeting. But there is no need to worry; the credencial letters from Maputo work their magic. Mr. Paulo Kalambo (the secretary for the Organization and Registration of Members and History) - who is in charge in the absence of the provincial secretary-welcomes me with open arms. Yet after quietly listening to my plans about interviewing female excombatants, Mr. Kalambo turns very serious. He insists that first, before going any further, I need to understand something about the situation and sentiments of ex-combatants in Niassa. With a somber face and empathetic body language, he then starts to describe the "miserable living conditions" of ex-combatants. "Many," he explains, "don't have proper houses but live in houses of capim." Their overwhelming sentiment, as he further elaborates, is that of sadness. Others, he insists, even die of these negative feelings. After "sacrificing their lives" (their youth that they can never have back), they should be living good lives, he argues, yet while the chefes in Maputo are living well, the ex-combatants in Niassa are suffering. As he describes, many suffer from mental problems; others lose the will to live completely. He says that he wants to explain this to me because normally the female ex-combatants refuse to be interviewed about their participation in the liberation struggle. They want nothing to do with such activities (referring to the political work of ACLLN, a Frelimo organization).

Mr. Kalambo's speech makes a strong impression on me, and for a while after our encounter, I am left wondering what is to become of my research. But as I continue my recruitment efforts, I soon discover that DFs are not as impossible to interview as initially envisioned by Mr. Kalambo. This is largely due to the sensitive mobilization skills of a female ex-combatant called Helena Baide. Together, we take to the bairros of Lichinga as well as the rural villages of northern Niassa to locate these women and talk to them about their lives and experiences in the guerrilla army. While most of the DFs we encountered happily agreed to be interviewed, a lot of the interviews were characterized by emotional outbursts commenting on the situation of ex-combatants in Niassa and the ex-combatants' relation to the Frelimo state. ${ }^{2}$ It was this disappointment and anger that clearly motivated many ex-combatants to participate in the interviews. Their talk about negative bodily feelings became a central focus 
of my research as I sought to understand how the war (and nationalist politics) had shaped and continued to shape the ex-combatants' sense of attachment to space and community.

The body is the central category of analysis throughout this study. Despite its relevance to understanding postcolonial history, the embodied experience of violence is still a curiously absent subject of investigation in studies on the armed struggles in southern Africa. This analytical perspective is also important considering how little attention the "body" has received in the study of war memories/histories or the study of the political field. ${ }^{3}$ In Part I, I discussed how the nationalist discourse opened a new political space or, borrowing from Oksala, provided a "rearticulation of the intersubjective horizon of meanings" that also allowed for bodies to be conceptualized and enacted differently. The social categories of "man" and "woman" were expanded with new meanings through the revolutionary discourse. Yet, as I also showed, the bodily histories of the ex-combatants are marked by significant discontinuities between this discourse and lived practice. Moreover, the new discourse did not erase the older cultural meanings of "man" and "woman." Even today, these different meanings continue to coexist, and the DFs creatively negotiate their own gendered bodily space within these discursive spaces. The following three chapters will continue to explore this relation between discourse and lived experience. While Part I discussed the discursive making of bodies, Part II takes a phenomenological approach to the body. Here, my starting point is in Maurice Merleau-Ponty's phenomenology of the body, which highlights the centrality of the human body in knowledge production. ${ }^{5}$ As he argues, all knowledge of the world is arrived at through our bodies, for consciousness is always already embodied. ${ }^{6}$ Moreover, our primary contact with the world is through our senses, as they put us "in touch" with the world and relate us to other sensing bodies. This does not, however, mean that our knowledge of the world is purely subjective. For, as Käll writes, the body is shaped through the interconnected dimensions of exteriority and interiority. ${ }^{7}$ Even sensory experience, as Mark Paterson, Martin Dodge, and Sara MacKian further insist, "does not reside solely with the boundaries of the skin, somehow locked with discrete, disconnected bodies." 8 Rather, our sensory experiences and bodily ways of knowing are always intersubjectively shared and thus culturally constituted. ${ }^{9}$

In Chapter 2, "Female Combatants and Gendered Styles of Being," I focus on how the experience of soldiering in the liberation struggle shaped (and continues to shape) the DFs' perceptions of their gendered bodies and the relation of their bodies to the surrounding material and social world. In my analysis, I draw on feminist readings of Merleau-Ponty's concepts of "body schema" and "style," especially the writings of Sara Heinämaa and Johanna Oksala. I show that movement is integral to the conceptualization of the body. Bodies are made in movement; moreover, they generate their own space through movement. ${ }^{10}$ This is a crucial point to make considering that in mainstream theories of nationalism, national space is often conceptualized as the static female body while historical time/temporality is theorized as masculine. In Chapter 2, I question 
these dichotomous relationships, showing how DFs negotiate between masculine- and feminine-coded ways of being in the world and, moreover, how new meanings and gendered spatialities are generated in the process. In Chapter 3, "Guerrilla Life and the Haptics of the 'Bush,', I continue focusing on the remembered experience of soldiering in the war. I analyze, especially, the sensory memories of the body-landscape relationship during the war and how the "bush" and the combatant body were shaped in relation to each other in this often-violent contact. In Chapter 4, "Body Feelings and Violent Memories," I focus on how these violent memories still shape the ex-combatant body and how the meanings of these war experiences are negotiated today. As I argue, the key political notions of the wartime nationalist discourse are intimately linked to sensory ways of knowing and thus tied to the individual and collective bodies of the war veterans. But I will come back to this later. First, I start by looking at the gendered making of the soldier's body during the war and its transformation into the ex-combatant body in the postindependence period.

\section{Notes}

1 I told this story also in Jonna Katto, "Emotions in Protest: Unsettling the Past in Ex-Combatants' Personal Accounts in Northern Mozambique," Oral History 46, no. 2 (2018): 53-62. Reprinted here by permission of the Oral History Society (www.ohs.org.uk).

2 Since taking over state power at independence, Frelimo has largely controlled the state and dominated state politics, and thus it remains valid to talk of a "Frelimo state."

3 In more recent years, there has, however, been an emerging body of literature in this area. See, e.g., Kevin McSorley, ed., War and the Body; Sarah De Nardi, The Poetics of Conflict Experience: Materiality and Embodiment in Second World War Italy (London: Routledge, 2017); Susanna Trnka, Christine Dureau, and Julie Park, eds., Senses and Citizenships: Embodying Political Life (London: Routledge, 2013).

4 Oksala, "Female Freedom," 226.

5 Maurice Merleau-Ponty, Phenomenology of Perception, trans. Colin Smith (London: Routledge, [1945] 2002).

6 Ibid.

7 Käll, “A Being of Two Leaves,” 110-133.

8 Mark Paterson, Martin Dodge, and Sara MacKian, "Introduction: Placing Touch within Social Theory and Empirical Study," in Touching Place, Placing Touch, eds. Mark Paterson and Martin Dodge (Aldershot: Ashgate, 2012), 2.

9 See, e.g., Kathryn Linn Guerts, Culture and the Senses: Bodily Ways of Knowing in an African Community (Berkeley: University of California Press, 2002); Alexandra Y. Aikhenvald and Anne Storch, eds., Perception and Cognition in Language and Culture (Leiden: Brill, 2013).

10 Manning, Politics of Touch. 
$\because$ Taylor \& Francis Taylor \& Francis Group http://taylorandfrancis.com 


\section{Female combatants and gendered styles of being}

\section{Stretching the body}

"It is clearly in action," Merleau-Ponty writes "that the spatiality of our body is brought into being." In this subchapter, drawing on feminist readings of Merleau-Ponty's phenomenology of the body, I look at how the embodied experience of soldiering in the liberation struggle affected in various ways the DFs' perceptions of their bodies and the relation of their bodies to the surrounding material and social world. My analysis will focus especially on segments from a conversational interview I had with a DF called Maria Ajaba. During the war, Maria worked as a vice political commissar of the DF at FRELIMO's Central Base of Ngungunyane in Niassa Ocidental (see Map 3.1 on page 100). Nowadays, Maria is a grandmother, a farmer, and a war veteran, but she also continues to be actively involved in the political work of ACLLN and the Frelimo party. In the following interview segment, Maria speaks of how military training gave her a new experience of her (gendered) body. As she narrates,

I . . the war ... the experience that I have ... hmm ... when I entered in the war ... and started to MOVE. Mm. Now, to gain experience in my body, to manage to stretch inside the war, first it was in the training. I remember the training that we did. They taught us that when one encounters the enemy, the person has to run. If one wants to attack, one has to go attack when the body-when it is good. Then go attack and return. [clears her throat] That is why, I appreciated/experienced the war with my body. I appreciated/experienced through the training because I didn't know that ... how I was going to move. I moved like a WOMAN. So from there, I trained. I moved like a man. Hehe. ${ }^{2}$

As Maria accounts, military training enforced a physical transformation. New ways of moving and positioning her limbs became instilled in her "muscular consciousness."3 Maria speaks of a "stretching" of her body, which implies that the training forged different muscles and movement paths from ones she had grown accustomed to using in her premilitary life. Prior to military training, her habitual body - and I refer here to the body as "sedimentation of values and 
meanings, created by former bodily acts"4_lacked the experience of "moving" in the war. In Maria's account, moreover, the new movements and bodily gestures taught through military training are defined as masculine ("So from there, I trained. I moved like a man."). Before, "I moved like a WOMAN," she explains. According to her, "female" motility is shaped by the daily routines of women's work, as she elaborates further in the following segment.

JONNA: Can you explain this difference ... of moving like a woman and moving like a man? Hehe.

MARIA: Aah. A woman moves ... thinking ... about her work. Hm? So, when I trained ... I CHANGED-my life, my body, the way of moving. I moved with strength/power ...hm? With strength, to say that, I am an element ... OF THE WAR. I'm going to war. I'm going to fight. I'm going to run. Eeh? So, all of that training ... made me, my body. And living in the war ... until making it through. ${ }^{5}$

Maria, and the other ex-combatant women I interviewed, spoke of how daily life in the rural communities where they had lived before the war had been largely separated into male and female spheres of activities. From an early age, girls would start practicing the bodily motilities of the tasks that they were later expected to perform in a habitual manner as initiated female members of their societies. And as the women fondly remembered, they would often mix work with play: while their moms were working in the machambas (fields), a group of female friends would fetch water, take a swim in the river; collect firewood, pound maize, and then, for instance, have a break to play ndodo, a game that girls played with marbles. As a special form of amusement, the girls would prepare food among themselves in the bush and thus have what they called a "picnic" (Ciyaawo: massanje); sometimes, boys were also included in the fun, and the girls would serve them the ugadi (thick maize porridge) they had cooked. Massanje was both fun and educative. ${ }^{6}$ Learning these female gendered taskscapes involved, ${ }^{7}$ among other things, grasping the perceptual system of balancing pots, bundles of firewood, and other loads on their heads and practicing the specific moves and the special muscle prowess needed to pound maize into flour and cook maize porridge. As the girls grew older, they also started training for their coming roles as farmers and cultivators of food crops. They became familiarized with the movement paths of hoeing and preparing the machamba soil for planting the crop seed and at harvest time the techniques of drying and storing the maize cobs and the beans.

As Maria expresses in the previous interview extract, it is having these specific female-gendered tasks in her mind that direct her body movements and gestures. Generally, men did not have the same command of these tasks, except for working in the machamba, which was done together (though men directed more of their attention to the cultivation of cash crops, such as tobacco). Men were more involved in activities such as cutting trees, clearing the bush for new 
fields, building huts, hunting, and traveling long distances on foot "in search of money" (which meant going to sell tobacco at "Ciwambo" on the Quelimane coast or looking for paid work in the neighboring countries). Before the independence war, the matrilineal, and at the time matrilocal, Ayaawo practiced traveling polygamy, which meant that husbands would travel between the homes of their different wives, ideally dividing their work time equally between the family villages of each wife. This signified that women actually spent more time living with other women (e.g., their sisters and female friends) than with their husbands. Motherhood was practiced collectively. Children would refer to maternal aunts as mothers, sometimes differentiating by age: young mom and old mom. Moreover, matrilineal kinship relations such as the sister-brother and uncle-nephew relations were more important than the husband-wife relationship. Special intergenerational female bonds were also cultivated; for instance, many of the women I interviewed spoke of growing up in the houses and under the care of their maternal grandmothers (most of their grandfathers also practiced traveling polygamy). Generally, while the husbands were away, the wives were responsible for cultivating the fields and producing food for the family. Women were thus physically more closely tied to their ancestral lands and kinship group than the traveling men. This special relationship with the land also manifested itself in the position of the bibi (see page 22). The inheritance of land through matrilineal decent lines as well as the role of women as producers of food further consolidated women's relationship with the landscape and gave them significant autonomy and negotiating power within the family. ${ }^{8}$ Arnfred insightfully argues that gender identity in northern Mozambique before the liberation struggle (and before FRELIMO's new discourse on "gender equality") should be conceptualized as built on "ideas of complementarity between men and women." Her point finds resonance in my analysis. While women and men largely operated in their separate gendered spheres, work was still conceived of as being "done together" in the sense that both were contributing to the collective well-being. These gender conceptualizations and practices (as I will analyze later) still have certain continuity in today's context, even despite state-level ideological shifts and changes in the economic structure of society.

"Complementary social duality" 10 is, moreover, based on ideas of the different capacities of male and female bodies. Later in the interview, Maria speaks of how she understands the capacity of the female body, especially as it evolves through the different life stages:

The body can't feel like ... it were a girl. And ... the body always changes. A girl getting pregnant with a child, the strength is still there ... with the second ... the strength is still there. With the third-Until stopping to give $\underline{B I R T H}$, the strength is still there. From then on, the strength that remains is for working, it isn't for giving birth. $\underline{\mathrm{Ah}}$, it is for working. It is for your life. Eeh. So when you said, "Your body, how does it feel?"-I feel that the body is really growing/evolving/aging. Eeh. ${ }^{11}$ 
The excerpt shows how the physiological body is always entwined with cultural meanings of its capabilities. In Maria's account, the girl's/woman's "strength" is described as evolving in stages through the body's orientation toward different tasks. For Maria, childbirth meaningfully structures a women's life course. In Yaawo culture, especially in the times before the war, a woman was only considered a fully initiated member of society when she had given birth to her first child. ${ }^{12}$ Even today, a woman is often perceived "a girl" until she bears a child and steps into the social role of mother. Later, as Maria describes, when the time comes that she can no longer conceive, the woman is free to direct her attention more fully to other tasks until old age slowly transforms the motility of her body, restricting her work in the machambas. Many of the DFs I interviewed, including Maria, viewed themselves as having reached a stage in their lives in which their productivity has already greatly diminished, and their body strength has weakened. Maria, for instance, spoke of how in "looking at her movements these days," she cannot anticipate achieving many more things in life, and some of her projects (such as her "improved house" [Portuguese: casa melhorada; Ciyaawo: nyumba ga malata] with its zinc roof) will remain unfinished. While many negative aspects of aging were emphasized, it was evident that "old age" (seniority) coupled with the status of ex-combatant also signified positive factors, such as an elevated status within their extended families and financial independence. I will come back to analyzing the women ex-combatants' understandings of the gendered capacities of the body and styles of movement later, but first I turn to Merleau-Ponty's notion of the body schema, which I propose as a useful analytical tool to make sense of these multiple and shifting perceptions.

\section{Body schemas}

The "body schema," in Merleau-Ponty's theorization, is not a mental image but, as he writes, "a total awareness of my posture in the intersensory world." 13 The body schema is a person's subjective experience of their bodily motility and spatiality in relation to the environment. As feminist philosopher Johanna Oksala further analyzes, this schema is "the material body itself, as a structured capacity for actions and intentions." ${ }^{14}$ It encompasses past and present acts but also a corporeal anticipation of future acts. Moreover, the body schema is not an unchangeable construction, but what Gail Weiss (drawing on Schilder and Merleau-Ponty) calls a "dynamic gestalt." ${ }^{15}$ Weiss even suggests that we conceive of persons having multiple, coexisting body schemas. ${ }^{16}$ As she writes, a body schema changes in response to physiological changes in one's body, changes in other bodies, and changes (or anticipated changes) in the body's physical, social, and discursive situation. ${ }^{17}$ Our material bodies are always entwined with their cultural constitution, and even our ways of moving express our social and spatiotemporal constitution. ${ }^{18}$ In this sense, as Oksala argues, our experiences "always have linguistic, sociocultural and historical conditions of possibility." ${ }^{19}$ These conditions, Elizabeth Grosz further theorizes, "actively produce the body as a body of a determinate type." 20 Through our intersubjective engagement with the world and others, our bodies are marked by meanings and 
representations associated with categories such as gender, race, ethnicity, and class. Here, intersubjectivity is understood in terms of "cultural normality," 1 which, importantly, involves questions of power relations.

The body schema does not exist free outside normative regulation and power structures. Frantz Fanon famously shows how a "historico-racial schema" 22 composed by the "white man" has historically defined and restricted the possibilities of movement and self-expression of the "black" colonial subject. In his phenomenological account, Fanon describes his experience of this racializing body schema as "overdetermining" - "a meaning that was already there, pre-existing, waiting" for him. ${ }^{23}$ Feminist scholars have often criticized Merleau-Ponty for failing to theorize sexual difference and variation; ${ }^{24}$ also, Fanon gives little consideration to the experiences of the "black female." Iris Marion Young, in her influential essay, analyzes how normative gender schemas can restrict the experience of the capacity of the female body. Theorizing from the standpoint of Western urbanized society, she argues that women live an "inhibited intentionality" toward the world, which translates into "a self-imposed 'I cannot.",25 Still, categories such as "woman" and "black," as Fanon and Young both recognize, are generalized types; they intersect with other bodily and social distinctions (e.g., class, age, and ethnicity) that are varyingly marked and valorized depending on the historical and cultural constitution of the body-subject. For instance, Nigerian feminist scholar Oyèrónké Oyěwùmí has heavily criticized Western feminist researchers for examining African realities through Western gender categories that are based on the culture-specific notion of the nuclear family system (the male-headed, two-parent household), which, she argues, is foreign to many African experiences. ${ }^{26}$ She even claims that the male/female gender dichotomy and its accompanying "male privileging" — which for her is a constitutive factor of Western gender categories - does not exist in many African gender conceptualizations. ${ }^{27}$

Often, poststructuralist feminist theorists have problematized the compatibility of Merleau-Ponty's phenomenology of the body with poststructuralist theorization that emphasizes the cultural and historical constitution of the subject. They have argued that Merleau-Ponty's "tacit cognito" (the anonymous or prepersonal body) implies a foundational essence that, moreover, builds on a male heterosexual bias. ${ }^{28}$ Here, I draw on feminist phenomenologists who have argued that Merleau-Ponty's phenomenology has been partly misunderstood in this aspect. Oksala, for one, proposes a reading of Merleau-Ponty's body-subject that asserts "transcendental intersubjectivity-language, tradition, and community-as the reality constituting principle." 29 She argues that the "tacit cognito" should be understood through Merleau-Ponty's notion of reciprocity and thus not "as a foundational layer of subjectivity" but as "a constitutive condition" or "a dimension of intersubjectivity." 30 This means that there is no going back to an independently existing "anonymous body"; the body in Merleau-Ponty's phenomenology, according to this reading, is always historically constituted.

Apart from being historical, the body is also productive, ${ }^{31}$ construction and agency are not in opposition. As Butler elaborates, its discursive construction is the subject's "necessary scene of agency, the very terms in which agency is articulated and becomes culturally intelligible." 32 Yet repetition (or habit) always 


\section{Violent liberation}

involves creativity. ${ }^{33}$ While materializing sociocultural norms, the body creates its individual styles of repetition. ${ }^{34}$ Feminist phenomenologist Sara Heinämaa proposes that we understand femininity and masculinity as well as manhood and womanhood as styles of being. Heinämaa strongly argues against the sex/gender distinction that she claims still underlines a lot of feminist scholarship. Furthermore, she maintains that the argument that both "sex" and "gender" are sociocultural products often does not effectively do away with the sex/gender distinction, but that "part of the 'logic' of the distinction remains: the logic of raw materials and formative forces, causes and effects, and facts and fabrications." ${ }^{35}$ Heinämaa suggests that phenomenology can help overcome some of these oppositions of mind/body and culture/nature. As she writes, our sexual identities are "formed together with our sensing living bodies." 36 She purposes that Merleau-Ponty's concept of "style" — as a person's way of being in the world - can provide a different way to look at sexual identity and difference. In the following subchapter, I explore how thinking of gender as a "style of being" can contribute to an analysis of the female ex-combatants' gendered bodies and the ways they are shaped in the intersection of multiple discourses and material practices.

\section{Masculine and feminine styles}

Military training and practice cultivated new bodily intentionalities; Maria, for instance, speaks of becoming "an element of the war" (see page 80). The recruits were taught specialized bodily techniques and movement systems (for instance, how to attack and retreat). Moreover, as Maria claims, the military training introduced a "masculine" choreography of moves, which she continues to explain further in the following interview segment (the images accompanying the transcribed text are drawn from still frames captured from the interview videos; see Figures 2.1a-2.1d).

(a)

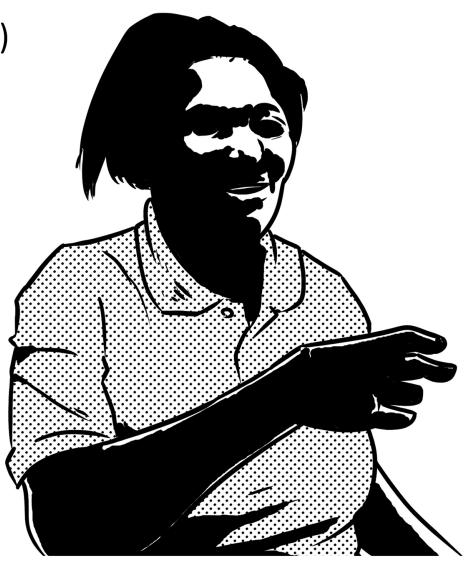

(b)

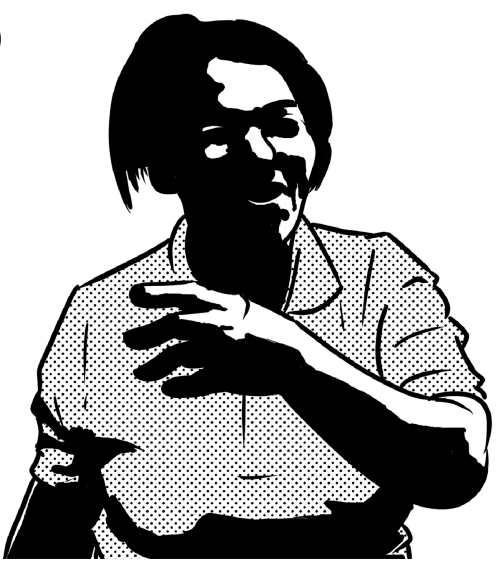

Figure 2.1 $\mathrm{a} / \mathrm{b}$ Masculine and feminine styles Source: Illustration by Mikko Kankaanpää 
MARIA: The woman, when . . . it isn't necessary to run, she moves normally: chaah, chaah, chaah, chaah, chah.

JONNA: Hehe. Aah.

(c)

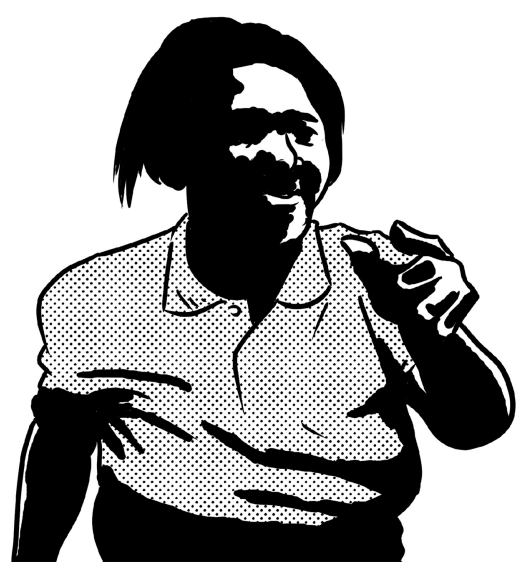

(d)

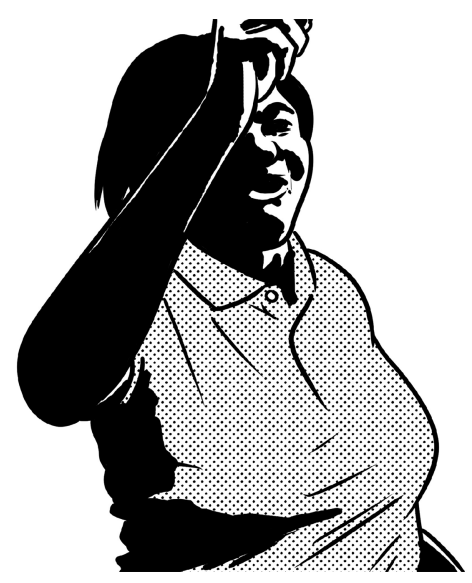

Figure 2.1c/d Masculine and feminine styles

Source: Illustration by Mikko Kankaanpää

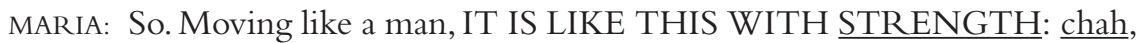
$\underline{\text { chah }} \underline{\text { chah }} \underline{\text { chah. }}$.

JONNA: Hehe. Okay. Hehe.

MARIA: Off you go! Right? Already going there! Saying I am firm. WHATEVER situation I find myself in here, I have to accept. If an airplane finds

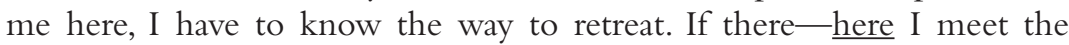
enemy, I have to know the way to ... to retreat, to take cover, so that I can fire the weapon against the enemy ... or not ... Always ... it is this movement of the man ... OF WAR. Hehe. ${ }^{37}$

The two series of movements that Maria performs are drastically different. While the first is a performance of a nonhurried, leisurely swaying gait, the second enacts a set of more forceful movements that push the body forward with apparent muscular strength. These two bodily performances incorporate different kinds of intentionality. ${ }^{38}$ Maria, moreover, defines the first series of acts as feminine and links them to peacetime while the second she characterizes as masculine and connects them to the war. Perceived as a masculine choreography of the body, military activity, as Maria's account exemplifies, directs a new kind of attention to the comportment and capacity of the female body. ${ }^{39}$ Cynthia Enloe, in her influential feminist critique of the military, argues 
that military institutions are fundamentally patriarchal, "run by men for men according to masculine ideas." 40 Even FRELIMO-despite incorporating ideas of "women's emancipation" into its ideological discourse (as I analyzed in Part I) - to a great extent institutionalized heteronormative military masculinity. ${ }^{41}$ A male/female gender binary was forcefully produced in the war, and "women" was discursively constituted as a new political category distinct from "men" and "oppressed by men." Though often described through seemingly gender-neutral language in political discourse - the ideal soldier body was still perceived and experienced as a certain kind of masculine enactment, or style of being, that Maria refers to as the "movement of the man of war."

Yet the gestural space of the body is also a site of resistance and of novelty. "Bodies," as Henri Lefebvre writes, "themselves generate spaces, which are produced by and for their gestures." 42 This "production" is both "repetitive and differential." 43 The body-subject, as Oksala further argues, while "an effect of an intersubjective normativity," is also "initiatory and capable of resistance." ${ }^{44}$ The body is an open "structure of signification" that can be "changed in repeated acts of deviation and subversion." 45 I suggest that the two stylized performances shown earlier need not be understood as simply reproducing the gender binary of male and female. Making use of Merleau-Ponty's concept of "style," Heinämaa insists that the question that matters when describing gender is not "what we are" but "how we are." ${ }^{6}$ She calls for gender to be understood as a weft of dynamically connected attributes, elements, and bodily acts. Even when we perceive permanence, it is, she claims, "not in the constancy of substance or in an attribute but the continuity of a mode of acting." 47 In everyday life, we often routinely categorize "human behaviour into two gender types, the feminine and the masculine." ${ }^{48}$ A person, she writes, is identified as a man or a woman through the "gestures, expressions and postures that continue-but also change - a given rhythm and melody of movement." ${ }^{49}$ Gender is a stylized being and moving in the world. At the same time, individual acts not only "continue the dichotomy of gender styles but they can also take it apart." Thus the concept of "style" in Heinämaa's reading allows us to conceptualize a variety of differences in sexual and gender identity that break with the dualistic system of male and female. I think it also allows us to work against the grain of the male bias of Western gender categories, of which, especially, African gender scholars have been highly critical. ${ }^{51}$ The concept of style is inherently dynamic, as I will also show through the following excerpt.

MARIA: For this reason ... mmm ... the situation of my body, the feeling, and of remembering-I'm still remembering the war, iih, firmly . . . with all,

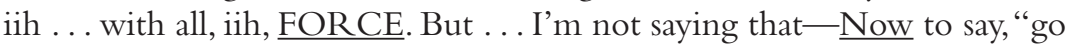
there fight in that country." [laughs lightly as she speaks] Will I manage? JONNA: Hehe.

MARIA: [Laughs lightly as she speaks] No! The body is already a little bit tired. Eeh. JONNA: Hehe. Now you can't move like a man? Or can you? Your body ... can it manage?

[Jonna and Maria laugh together.] 
MARIA: Hahaha [laughs loudly]. When there is a situation (JONNA: Aah.), as when I saw you-I RAN.

JONNA: Aah, it's true I saw.

MARIA: [Laughs lightly as she speaks] Isn't it?

[Jonna and Maria laugh together.]

MARIA: I ran: pah-pah-pah-pah-pah! I said, to walk like this, I wo-I won't catch up. But to walk-eh, enter in my house together, I have to run. Eheh? So also like this, when there is a situation that requires walking/moving

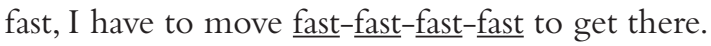

JONNA: Like a soldier?

MARIA: Like a soldier.

[Jonna and Maria laugh together.]

MARIA: But if it's a normal situation, I walk normally. Yaa-a. It's true. ${ }^{52}$

Running to catch up with me as I am about to enter her yard is a rather mundane act, and indeed, its significance is not in the act itself but in its style. I remember my own surprise at the athletic movements and trained rhythm of Maria's moving body as I turned around to the sound of my name being called. During my fieldwork, I had not seen other women her age run with the same kind of agility. Yet in the interview situation, I had already forgotten about this incident - and probably would not have stopped to consider its meaning-if Maria had not brought it up as an example of "masculine movement."

Jack Halberstam argues that masculinity be reconceptualized as not inherently and naturally tied to male bodies. ${ }^{53}$ Both maleness and femaleness can be enacted in the same body. Also, Heinämaa convincingly argues that "femaleness, as a style of being, cannot be pinned down by a common source or form: it can only be conceived by studying its concrete manifestations and the various relations between them." ${ }^{54}$ None of the women I interviewed can be described as identifying with a predominately "masculine" style of being or with what Halberstam calls "female masculinity." 55 Rather, the various conversations showed how many of the women had had to negotiate between "masculine" and "feminine" coded ways of acting their corporeality. This is also exemplified in Maria's accounts. "Normal" is defined as something other than masculine. In peacetime, masculine motility is not the idealized norm, nor is female motility marked as inferior. ${ }^{56}$ At the same time, "female" (though described as different) is not opposed to "masculine" motility, and "when a situation requires," as Maria insists, masculine-coded styles of movement may also be brought into action. This illustrates how gender style is a creative choreography of movement that involves negotiations between multiple coexisting body schemas. After all, the unity or coherence of a style is established, as Heinämaa explains, through the dynamic and changing connections that are made between its different expressions. ${ }^{57}$

Training and military practice shaped experiences of what a female body was capable of doing. Military training extended women fighters" "body schema(s)" in a distinctive way (this is expressed, for instance, as the cultivated "readiness" of 
the body to act "when the situation requires"). This also exemplifies how habit is the basis for creativity. The guerrillas had to adapt learned choreographies of movement to changing situations-for instance, surprise attacks. During war, the normative restrictions on their gendered motility changed, and the DFs expressed being "allowed" to do things that had previously been prohibited. At the same time-as the women accounted numerous times in the interviewsthrough military training, women learned that they could accomplish the same tasks as men. There were, of course, differences between women, and in reality, all women did not perform all the same tasks as men, such as participate actively in combat. But most of my interviewees maintained, however, that for "women" as a group, certain gender boundaries were reconfigured in the context of the revolutionary war. What is emphasized is a bodily way of knowing. The women also spoke of how military training physiologically changed their bodies and how they grew stronger physically (this is expressed in a strength that their aging bodies no longer have). Military training and movement in the war not only extended the strength of the body but also required the body to "stretch" to its limits. In the interviews, this "strength" was often not explicitly linked to "male" or "female" motility but to age. For instance, one DF, Rosa Mustaffa, talked about how during the war, the DFs had to carry things that "they didn't have the age to carry." 58 And even though their work continues to be physical, as she explained, the big difference is that now in peacetime, a person determines for herself the size of the load she will carry. Knowing her own strength, she will make sure that the weight is appropriate to the length of the journey. However, in the war, one did not have the choice, and as a result (as I will explore further in a later chapter), some women (and men) argue that their work during the war permanently changed and even damaged their bodies. The body of youth is remembered as both strong and fragile. On the one hand, the young body was more elastic, and through hard work, one's muscles would expand, and one would grow stronger. On the other hand, the young body endured hardships and violence that also marked and molded it in profound ways.

\section{Ex-combatant bodies}

Returning to civilian life after the war, some women told of how they had to readapt their bodies to act according to different expectations of female behavior. The army had taught the women how to be more assertive and how to use their "voices" in public meetings. This was partly in contrast with the rules of decent female behavior that they had been taught when undergoing initiation rites prior to the start of the war. Yet after the war, the policing of behavior and punishing of bodily acts that deviated from normative gender expressions, and the fear that was linked to being ostracized, led some to actively change their bodily comportment and voice. For instance, after being demobilized, all my interviewees returned to wearing capulanas, even though many spoke of how they had gotten used to wearing trousers in the military and how 
uncomfortable and strange it had been for them to start wearing the capulana on a daily basis. The military uniform had effectively shaped experiences of the motility and capacity of their bodies. Wearing the capulana required another kind of awareness of their bodily comportment. Rosa spoke of how even today she has difficulty tying the capulana on in a secure fashion that will hold through the movement of the day.

ROSA: This capulana I tied like this [demonstrates how she ties]. So that there at home, I don't know how many times, it will fall off.

[Jonna and Maria laugh together.]

ROSA: Hehe, because we got used to trousers only, to put them on and to tie them up and that's it, off you go.

JONNA: Hehe. But here it isn't possible for a woman ... to wear trousers and not to wear a capulana?

ROSA: Aah, here they wear but-many people wear-but we, now like this as ... we already are - as we passed the time/stage, as they say, your time has already passed-we are already old [já somos grandes], THEY WILL laugh at us: "IIH, look there she used trousers!"

[Jonna and Maria laugh together.]

ROSA: She used trousers only without capulana! Hehehe [laughs loudly]..$^{59}$

Judith Butler famously writes of the "terror and shame of being told that we are somehow doing our gender wrong, that we have failed in some way to measure up to the cultural norm and expectation." ${ }_{60}$ The previous example does not speak of terror, but it does speak of the power of shaming. Rosa insists that she and other DFs are not ashamed of having worn trousers, yet, as her interview talk shows, these days, the threat of laughter keeps her in line with the normative expectations for the comportment and bodily expression of a "respectable older woman." Here, notions of age and gender intersect to produce ideas of appropriate feminine behavior. These meanings of feminine respectability, moreover, become attached to the capulana, which for the female ex-combatants became a new site of gendered identity negotiation in postwar Mozambique. ${ }^{61}$

Rural and urban settings also create different expectations for female bodily practices. Rosa lives in the rural village of Muembe, which is located around $70 \mathrm{~km}$ from Lichinga. The pressure to conform is more evident in the small villages of rural Niassa than in the more populous urban area of Lichinga. Since many of the DFs were so young when they left for war, they had not learned, for instance, how to farm and cook properly. After the war, some of themespecially in the more rural areas-felt mocked by their neighbors and others in their new communities for not knowing how to fluently perform the different gendered tasks expected from them as adult women. But even in urban areas, women experienced pressure to conform to more traditional norms of female respectability and comportment. Women like Maria, for instance, were described by others as having "bad mouths," meaning that these women were 
not afraid of making critical interventions but would speak their minds, including at political meetings. Speaking out in political meetings used to be encouraged during the struggle; in the "revolutionary space" of the bush, the young (women and men) could criticize and teach their elders, something that had previously been unheard of in a society in which respect was largely earned through seniority. These days for many DFs, it is a source of pride that being an ex-soldier is somehow visible in the comportment of their bodies. And Helena (whom I worked very closely with), for instance, spoke quite proudly and with a certain amount of defiance of how her "mouth has no security," and I saw her in action many times, educating or telling off ex-combatant colleagues (male and female), Chief Ce-Mataka and his advisors in Mavago, government officials, etc. Voice is an inherent part of one's corporeal style and engages one with the world. B. Farnell befittingly refers to speaking as "dynamically embodied signifying acts." ${ }^{2}$ Also, Maria talked about the difference that exists in the corporeal styles between women who trained as soldiers during the war and "other women."

MARIA: Hmm, there is a difference . . . between other women and a trained woman. Be it now ... working with people-be it at a meeting with people that don't ... don't have experience of . . of the . . . of the war, it's different. Because ... the one who already got used to being/staying with FAMILY, ONLY that family - then at the meeting the person usually becomes ... embarrassed like this. (...) Hmm, hehe, because already-we already got used to it, they [the women] already got used to it. Hmm, she is different from the one who didn't train. The person who trained, be it moving - we trained a lot of time, but . . . the person who didn't train, to go together, there is a difference. Be it in the conversations, there is a difference. Hmm. . . Be it in the family ... I who went to train in military life, and a family that never trained. It's different, different. Hmm.

JONNA: Yes, yes. ... And the major difference is?

MARIA: It's the biggest difference because you ... EVERYTHING ... you do with force/strength. Hmm? Be it talking. Hmm? It appears that $\underline{\mathrm{I}}-\mathrm{You}$ go to have a conversation with people who never trained ... you will see it's different from ... from us who ... trained. You'll see. You'll meet a woman talking - the one who didn't train-you will see, she won't stay/position herself like this, she will stay/position herself like this, sometimes like this. [She assumes the body posture of a seemingly timid person with downcast eyes as she speaks in a low uncertain voice:] "Something, like something, eeh, that, I that, eh-eh, I don't know." 63

Later, Maria compares the "other" woman's corporeal style of talk to that of a child who has not yet undergone unyago (initiation rituals) ${ }^{64}$ and has not been properly socialized. The initiation ritual, which I will discuss more in Chapter 7, is a powerful and central site for the social production of Yaawo 
womanhood. ${ }^{65}$ Interestingly, in the case of the female ex-combatants, the army offered an additional different kind of initiation. I sometimes witnessed how women ex-combatants who no longer had the assertiveness (in speech and body language) that was commonly associated with being an ex-combatantwere scolded by their female colleagues for not performing the ex-combatant body correctly. They were reprimanded, for instance, for not having the "right" kind of straight posture, not looking a person in the eyes when talking (downcast eyes are a more traditional sign of respect), or for "not knowing how to talk properly" if they did not manage to express their opinions in a concise and confident way. Sociolinguist Nikolas Coupland argues that linguistic style is performed in dialogue with one's social environment; ${ }^{66}$ this holds equally true for corporeal style. The examples, moreover, illustrate how, at different moments in different social situations and places, one body schema might "clash" with another, which can have unexpected effects also in terms of gender expressions, as it requires new negotiations of social norms.

The body expresses one's relationality with the world. I will introduce one final interview segment in order to sum up the themes that I have discussed in this chapter. In the conversation that follows, Helena and Amina try to explain to me what in one's bodily expression shows that one is an ex-combatant.

HELENA: Ca cikuwonerya kuwa HELENA: What shows that you are an antigu kumbatente?

AMINA: Aah, kudicimbicirya.

HELENA: Kudicimbicirya?

AMINA: [Bursts out laughing and laughs loudly as she responds:] Yelo. Hehe. HELENA: Respeito assim.

AMINA: Wucimbicimbi. Hehehe [laughs loudly]. ex-combatant? AMINA: Aah, I'm respecting myself. HELENA: Respecting yourself?

AMINA: [Bursts out laughing and laughs loudly as she responds:] Yes. Hehe. HELENA: I respect like this.

AMINA: Respect. Hehehe [laughs loudly].

[Amina continues laughing while Helena and I speak.]

JONNA: De que manei-

HELENA: Se respeitei aí [refers to body posture].

JONNA: Aah-ah.

HELENA: Hmm. Como uma pessoa grande [refers to social status].

JONNA: Aah-ah.

AMINA: Eeh. Hehe.

HELENA: Antigo combatente tinha respeito. É esse então que eu tirei. AMINA: Hehe, eehe.

JONNA: [Overlapping speech] Aah, mas pode explicar um pouco para mim porque eu não estou a entender.

JONNA: Which wa-

HELENA: If I respected like that [refers to body posture].

JONNA: Aah-ah.

HELENA: Hmm. Like a grown-up person [refers to social status].

JONNA: Aah-ah.

AMINA: Yes. Hehe.

HELENA: An ex-combatant had respect.

It's that that I took.

AMINA: Hehe, yes.

JONNA: [Overlapping speech] Aah, but can you explain a bit for me because I don't understand. 
HELENA: Disse se respeitou.

JONNA: Se respeitou? . . Significa o quê?

HELENA: Por exemplo uma pessoa quer respeitar o corpo dele, neh?

JONNA: Aah-ah.

HELENA: Não, não levou aquela posição de ser como . . uma menina ... ou uma pessoa que não gira. Então tirou como uma pessoa [AMINA: Hehe, eehe!] que tem família ... e tem responsabilidade em casa dela. Essa aqui.
HELENA: She said that she respected herself.

JONNA: She respected herself? . . . What does it mean?

HELENA: For example, a person wants to respect their body, isn't it?

JONNA: Aah-ah.

HELENA: She didn't take the position of being like ... a girl ... or a person who isn't all there. So she took [her position] as a person [AMINA: Hehe, eehe!] who has family ... and responsibility in her home. This one here. ${ }^{67}$

In this chapter, I have analyzed the DFs' life narratives as body histories. ${ }^{68}$ The previous interview segment beautifully brings this historicity of the body into focus. As I have shown through my analysis, the DFs' perceptions of their bodies and the relationship of their bodies to the surrounding world have evolved through their life trajectories. I have also looked at how these transformations have been tied to cultural shifts in the available body schemas. My focus has been especially on the changes that the revolutionary discourse and practice of soldiering introduced. As the narratives show, the body schemas available to the young girls growing up before wartime were expanded during the war through new ideas and corporeal knowledge about the possibilities of the female body. Soldiering introduced masculine-coded ways of being in the world that also became a part of the DFs' habitual bodies. Though in FRELIMO's socialist discourse, the army was defined as a gender-neutral space, soldiering privileged certain masculine styles of motility that emphasized physical strength and combat skills. Still, other spheres of activities privileged feminine-coded styles. Highly valued tasks such as political mobilization became a female sphere of activity that allowed women to conceive of themselves as equal contributors to the struggle. War is often theorized as a liminal space where gender roles are expanded as a requirement of the war effort. Often what is more interesting than looking at the new bodily schemas that are introduced during wartime is to examine what happens after the war and not even immediately after but after several decades have passed. The life histories of the Mozambican women ex-combatants are especially interesting since they capture a longer historical perspective. As I have shown, the women's life narratives and memories point to how many of the women still continue to negotiate between multiple coexisting body schemas and their different masculine- and feminine-coded ways of being in the world. New meanings and gendered spatialities are generated in this creative repetition. Importantly, age is a significant intersecting category of difference that contributes to the changing relationality between body and 
world, as the previous conversation demonstrates. In the bodily expression that is recognized as (female) ex-combatant, the body schema of combatant intersects with the body schema of grandmother. The relation of respect that Amina and Helena argue characterizes a female ex-combatant's relation to the world is linked to both age and the social status of ex-combatant. For instance, the respect that these women command as female elders in their families is defined by both. It is also noteworthy that Helena speaks in the past tense of how "ex-combatants used to be respected," suggesting that the position of ex-combatant was more valorized in the past. As I discuss later, the relationship between ex-combatant and the wider society is often characterized not by respect but by hurtful feelings of disrespect. But before this, I turn to look at the ex-combatants' sensory memories of the bush during the war and their memories of the violent tactility that characterized their body-landscape relationship. Through my analysis, I will develop the notion of the haptics of the "bush," which, as I will show, plays an important role in the ex-combatants' continued negotiations for socio-spatial belonging.

\section{Notes}

1 Merleau-Ponty, Phenomenology of Perception, 117.

2 Interview with Maria Ajaba, Lichinga, June 19, 2014.

3 Gaston Bachelard, The Poetics of Space, trans. Maria Jolas (Boston: Beacon Press, 1994 [1958]).

4 Heinämaa, "Woman-Nature, Product, Style?" 302. See also Merleau-Ponty, Phenomenology of Perception, 150.

5 Interview with Maria Ajaba, Lichinga, June 19, 2014.

6 See also Luís Wegher, Um olhar sobre o Niassa, vol. 2 (Maputo: Paulinas Editorial, 1999).

7 See also Ingold, "Temporality of the Landscape." His notion of "taskscape" refers to the human dwelling activities and relationships that intertwine with and constitute the very materiality of landscape.

8 See also, e.g., M. Anne Pitcher, "Conflict and Cooperation: Gendered Roles and Responsibilities within Cotton Households in Northern Mozambique," African Studies Review 39, no. 3 (1996): 81-112.

9 Arnfred, "Women in Mozambique," 9.

10 Ibid.

11 Interview with Maria Ajaba, Lichinga, June 19, 2014.

12 Amaral, Povo Yao, 58-61.

13 Merleau-Ponty, Phenomenology of Perception, 114.

14 Oksala, "Female Freedom," 213.

15 The body schema is both a stable perceptual background and an open structure; it incorporates both sedimentation and spontaneity. Edward S. Casey, "Habitual Body and Memory in Merleau-Ponty," Man and World 17 (1984): 279-297. See also MerleauPonty, Phenomenology of Perception, 95.

16 Gail Weiss, Body Images: Embodiment and Intercorporeality (London: Routledge, 1999), 9, 166.

17 Ibid., 17.

18 See Tim Ingold, "Three in One: On Dissolving the Distinctions between Body, Mind and Culture," in Imagining Culture: Practices of Cosmology and Identity, eds. Nils Bubandt et al. (Aarhus: Aarhus University Press, 2003), 40-55; Greg Downey, "Educating the Eyes: Biocultural Anthropology and Physical Education," Anthropology in Action: Journal for Applied Anthropology in Policy and Practice 12, no. 2 (2005): 57. 


\section{Violent liberation}

19 Oksala, "A Phenomenology of Gender," 234.

20 Elizabeth Grosz, Volatile Bodies (Indiana: Indiana Press, 1994), x.

21 Oksala, "Female Freedom," 221.

22 Frantz Fanon, Black Skin, White Masks, trans. Charles Lam Markmann (London: Pluto Press, 2008 [1952]), 84.

23 Ibid., 102. His account shows how this historico-racial schema becomes inscribed on his very skin as a "racial epidermal schema," interrupting his personal corporal schema.

24 See Judith Butler, "Sexual Ideology and Phenomenological Description: A Feminist Critique of Merleau-Ponty's Phenomenology of Perception," in The Thinking Muse: Feminism and Modern French Philosophy, eds. Jeffner Allen and Iris Marion Young (Indianapolis: Indiana University Press, 1989), 85-100; Sara Heinämaa, Toward a Phenomenology of Sexual Difference: Husserl, Merleau-Ponty, Beauvoir (Oxford: Rowman \& Littlefield Publishers, 2003), 22. Linda Alcoff argues that phenomenology is also affected by "racialized and Eurocentric assumptions." Alcoff, "Phenomenology, Post-structuralism, and Feminist Theory."

25 Iris Marion Young, "Throwing Like a Girl: A Phenomenology of Feminine Body Comportment, Motility, and Spatiality," in On Female Body Experience: "Throwing Like a Girl" and Other Essays (New York: Oxford University Press, 2005), 36. Compare Dianne Chisholm, "Climbing like a Girl: An Exemplary Adventure in Feminist Phenomenology," Hypatia 23, no. 1 (2008), 9-40. Chisholm explores how women can cultivate "free movement" and break with normative and restrictive "feminine" motility.

26 In her study of the Yoruba family, she argues that seniority and not gender is the most important "organizing principle." Oyěwùmí, "Conceptualizing Gender," 1-8.

27 See also Ifi Amadiume, Reinventing Africa: Matriarchy, Religion and Culture (London: Zed Books, 1997).

28 For example, Butler, "Sexual Ideology"; Grosz, Volatile Bodies, 109-111.

29 Oksala, "Female Freedom," 212.

30 Oksala, "Female Freedom." See Heinämaa on her reading of Merleau-Ponty's concept of the anonymous. "Personality, Anonymity, and Sexual Difference: The Temporal Formation of the Transcendental Ego," in Time in Feminist Phenomenology, eds. Christina Schües, Dorothea E. Olkowski, and Helena A. Fielding (Bloomington: Indiana University Press, 2011), 41-59. See also Grosz, "Merleau-Ponty and Irigaray."

31 Oksala, "Female Freedom," 225.

32 Butler, Gender Trouble, 201. See also Wendy Parkins, "Protesting like a Girl: Embodiment, Dissent and Feminist Agency," Feminist Theory 1 (2000), 59-78.

33 Merleau-Ponty, Phenomenology of Perception, 164.

34 Oksala, "Female Freedom," 225. See also Galen A. Johnson, The Retrieval of the Beautiful: Thinking Through Merleau-Ponty's Aesthetics (Evanston, IL: Northwestern University Press, 2010), 17.

35 Heinämaa, "Sex, Gender and Embodiment," 228.

36 Heinämaa, "Phenomenology of Sexual Difference," 149.

37 Interview with Maria Ajaba, Lichinga, June 19, 2014.

38 Intentionality, as Wendy Parkins insists, is "bound up in the very performance." Parkins, "Protesting like a Girl," 62.

39 Note that no mention is made of how men walk in peacetime.

40 Cynthia Enloe, Does Khaki Become You? The Militarization of Women's Lives (London: Pandora Press, 1988), 7.

41 Samora Machel epitomized military masculinity in many narratives. He was described as tough, strong, untiring; he never hesitated to act, to kill even. These qualities made him a respected (meaning feared) military leader.

42 Lefebvre, Production of Space, 216.

43 Ibid., 395.

44 Oksala, "Female Freedom," 225.

45 Heinämaa,"Woman-Nature, Product, Style?” 302. 
46 Heinämaa, Ele, Tyyli ja Sukupuoli, 160-161.

47 Heinämaa, Toward a Phenomenology of Sexual Difference, 68.

48 Heinämaa, "Phenomenology of Sexual Difference," 139.

49 Heinämaa, Ele, Tyyli ja Sukupuoli, 163. On the relation between repetition and difference, see also Lefebvre, Rhythmanalysis, 6 .

50 "Style," as she clarifies, is the "birth of the norm" and not its expression. Heinämaa, Ele, Tyyli ja Sukupuoli, 162. Yet an individual act in itself will not change the structure, only repetitive acts of deviation. Heinämaa, "Woman-Nature, Product, Style?" 302; Heinämaa, "Phenomenology of Sexual Difference," 145.

51 See, e.g., Oyěwùmí, "Decolonizing the Intellectual and the Quotidian."

52 Interview with Maria Ajaba, Lichinga, June 19, 2014.

53 Halberstam, Female Masculinity.

54 Heinämaa, "Woman-Nature, Product, Style?" 301.

55 Compare Paredes, Combater duas vezes.

56 Compare Marion, “Throwing Like a Girl.” See also Chisholm, “Climbing like a Girl,” 11.

57 Heinämaa, "Woman-Nature, Product, Style?” 158.

58 Interview with Rosa Mustaffa, Muembe district, June 12, 2013.

59 Ibid.

60 Judith Butler, “Gendering the Body: Beauvoir's Philosophical Contribution," in Women, Knowledge, and Reality, eds. Ann Garry and Marilyn Pearsall (London: Unwin Hyman, 1989), 256.

61 Clothing is simultaneously a site of regulation and creative identity negotiation. See Jean Allman, ed., Fashioning Africa: Power and the Politics of Dress (Bloomington: Indiana University Press, 2004).

62 B. Farnell, "Moving Bodies, Acting Selves," Annual Review of Anthropology 28 (1999): 344. See also Ellen Hurst and Rajend Mesthrie, "'When You Hang Out with the Guys They Keep You in Style': The Case for Considering Style in Description of African Tsotsitaals," Language Matters: Studies in Languages of Africa 44, no. 1 (2013): 3-20. Hurst and Mesthrie show how in the South African urban language phenomena known as Tsotsitaal, linguistic style is closely tied to corporeal style and together account for the "identity performance" of Tsotsitaal speakers.

63 Interview with Maria Ajaba, Lichinga, November 28, 2012.

64 Unyago is the umbrella term for both male and female initiation rites. Nsoondo refers to female initiation rites. In the interviews, both unyago and nsoondo were used by the women to talk about female initiation rites.

65 See also Signe Arnfred, "Feminism and Gendered Bodies: On Female Initiation Rituals in Northern Mozambique," Quaderns 26 (2010): 61-82.

66 Nikolas Coupland, Style: Language Variation and Identity (Cambridge: Cambridge University Press, 2007).

67 Interview with Amina Ndaala, Lichinga, June 23, 2014.

68 Alongside "body histories" one could also speak of "sensory biographies." See Robert Desjarlais, Sensory Biographies: Lives and Deaths among Nepal's Yolmo Buddhists (Berkeley, CA: University of California Press, 2003). 


\section{Guerrilla life and the haptics of the "bush"}

July 17, 1965, I settled down in Maniamba, on Mount Chisindo. It used to take two hours to climb this mountain. On top of this hill is a world; one can see a very beautiful landscape. We established a very strong base here in Maniamba. ${ }^{1}$

Many ex-military commanders who served in Niassa during the war remember Niassa as a challenging landscape in terms of military strategy, with its vast territories and small population numbers. ${ }^{2}$ The dominating physical elements of the landscape of northern Niassa are its isolated mountains that rise out from an otherwise flat plain. These mountains also feature prominently in the oral histories of the region and especially in stories of the old wars. In difficult times, people often sought refuge, but also a military vantage point, near their summits. During the liberation struggle, the mountains played similar roles, as the previous quote from the testimonial account of ex-military commander José Moiane ${ }^{3}$ shows. Here, I chose to start with his words since his reference to the "beautiful landscape" that opens up at the top of Mount Chisindo stands in stark contrast to the lived environment of the bush talked about in the interview accounts of the women (and men) that I interviewed in Niassa. I suggest that Moiane's account might be read as a distanced and nostalgic remembering characteristic of the Maputo-based nationalist elite. As I will show in this chapter, those living in the actual landscape of Niassa express a different kind of embodied remembering in which the "bush" is often construed as the very opposite of a "beautiful" landscape. I will start by exploring the geography of "bush" and the processes by which it was shaped during the liberation struggle.

\section{Landscapes on the move}

That's why ... the experience of war ... we gained a lot. . . And I gained a lot because I suffered A LOT: Running, climbing the MOUNTAINS, descending, crossing rivers ... that don't have bridges. Getting wet there in the water, but ... 
never going back ... always, GOING forward . . . because it was to liberate our country. That experience even today ... is in my head - very unforgettable. ${ }^{5}$

The mountains, the bases, the guerrilla footpaths do not just frame the war but are intimately part of the haptic memories of the liberation struggle. While the colonial troops controlled the towns, roads, and villages connected by the roads, the "bush" became the lived environment of the guerrilla fighters. The war spatially divided the whole population of northern Niassa between the Portuguese controlled areas, the bush/forest areas held by FRELIMO, and the neighboring countries of Malawi and Tanzania. For the civilian population, the war landscape was simultaneously constituted through forced movement and forced immobility. ${ }^{7}$ Before the liberation struggle, as many of my interviewees mentioned, people often lived in small dispersed lineage groups. When the war started, the Portuguese colonial government forcefully removed people from their lands and brought them together into aldeamentos (fortified villages). These large settlements were located next to roads and were fenced off with barbed wire so that people could not escape to join the guerrillas. ${ }^{8}$

At the turn of the twentieth century, road building had been an important strategy for the colonial state to extend its presence into the northernmost areas of Niassa. Though this area was perceived as an isolated periphery by the colonial state, its peoples were immersed in complex and far-reaching trade networks long before the arrival of the Portuguese. In fact, the road network constructed by the Portuguese army to connect its military posts was based on the old caravan routes of the African dignitary. ${ }^{9}$ For the colonial state, the goal of road building was the creation of access routes that would better enable it to subject the population to taxation and military surveillance. Among the local people, the roads soon came to symbolize Portuguese colonial domination of the area, ${ }^{10}$ and the road building projects encountered strong resistance. In oral history, the great Yaawo chief Ce-Mataka III ${ }^{11}$ is remembered as the leader who fiercely opposed the building of the road from Vila Cabral (now Lichinga) to his center of power in Mavago. ${ }^{12}$ Yet despite strong resistance from successive Matakas, ${ }^{13}$ in 1912, the Portuguese colonial state finally managed to penetrate into the heart of Mataka country; the capital of his sultanate was invaded, and Mataka V fled into what is now Tanzania with about 45,000 of his people. ${ }^{14}$ In its place, the Portuguese constructed a military post (connected by a road all the way from Vila Cabral) and named it Tenente Valadim. ${ }^{15}$ Officially, this signaled Portuguese's effective control of these "remote" areas of Niassa. Yet at the same time, the roads that were few in number also demonstrate the limits of the reach of the colonial state over this vast area. People continued to move and thus "vote with their feet"; they could relocate into more remote areas or cross the border to neighboring countries (which they did in large numbers to avoid taxation and forced labor). ${ }^{16}$ Also, Nuno 
Valdez dos Santos, conducting a study on Niassa for the colonial government in the early 1960s, acknowledges in his report that it is not the roads but the trails that crisscross the forests, hills, and valleys that actually connect the different locales of the district (now province), and only the local people know how to securely orientate in its landscape. ${ }^{17}$

The control over roads and routes continued to play an important role in the politics of access to the land and people during the liberation struggle. FRELIMO successfully slowed down the advancement of the Portuguese ground troops by mining the roads, ${ }^{18}$ whereas the colonial army (during Kaúlza de Arriaga's campaign) cleared new roads into the bush. Ex-military commander Moiane boasts that it was because FRELIMO guerrillas successfully impeded the progress of the colonial troops on the roads that the Portuguese mostly used aerial transport. ${ }^{19}$ Since the FRELIMO guerrilla fighters had no access to airspace, the main roads, or transport vehicles inside the territory of Mozambique, for them, the geography of the liberation struggle was largely felt through the feet. This in itself did not mark a new historical development. As Paulo Israel writes, "From ancient trade caravans to migrant labor, the history of the region was largely written by foot." ${ }^{20} \mathrm{He}$ is referring to Cabo Delgado, but what he says applies equally to its neighboring province Niassa. During the liberation struggle, old routes were repurposed to serve the aims of the guerrillas. Gradually, these northern bush/forest thickets were transformed into a militarized zone: a network of bases and their connecting footpaths. Through the war years, the guerrilla fighters covered hundreds and hundreds of kilometers on foot, though distances were usually measured by counting the number of days. For instance, from N'sawisi to the Tanzanian border, the trek would take three days; from N'sawisi to Base Ngungunyane four to five days; and from Base Ngungunyane to Base Katur one week (see Map 3.1 on page 100). The guerrilla fighters were constantly on the move, traversing on missions between bases. New footpaths were forged, and reforged, into the bush in a constant fight against the bush taking over and covering the human trails. Local geographical knowledge was highly valued. "We had to know the geography of the places," as Moiane writes, "to determine the importance of the rivers, lakes, forests, mountains, to know the vantages of all of these things." 21 The high-ranking guerrilla leaders like Moiane, similar to the Portuguese soldiers, had no knowledge of the landscape of the bush but relied heavily on local guides. ${ }^{22}$ Moreover, as Moiane's account shows, the landscape was made sense of mostly through the terms of military strategy.

Mobility also plays an important role in constituting "histories and geographies of gendered difference." 23 For the DFs, one of their principle tasks during the war was the transportation of heavy loads of war material from the Tanzanian border to bases inside Mozambique. In the extract that follows, Rosa Mustaffa speaks of the movement and work of the DF during the war. 
JONNA: So, what kind of things did you carry?

ROSA: We ... we carried, iih ... We carried war material, isn't it? Aah, ammunition ... of heavy weapons.

JONNA: So it weighed-

ROSA: IT WEIGHED a lot, yes. Because, EIH . . . we carried a lot.

JONNA: So from Tanzania to?

ROSA: From Tanzania to Mozambique. To ... even here in Mozambique you could carry from here to other bases ... Aah. Because also there in the bush ... THERE EXISTED places ... distant- distant- distant places. So, we had to carry ... those things from here ... to the other side ... for others to use there. Aah. . . Taking from Tanzania to Mozambique. So in Mozambique there also were big bases that could store those things so that they could be divided to the other [smaller] bases. Aah. ... So all of that it was us [continues with laughter in her voice] carrying-

JONNA joins Rosa's laughter: Aah, the female detachment? Hehe.

ROSA responds with laughter in her voice: The female detachment. And ... with the population itself-Going to mobilize that population, going together with them, carrying [the material] to the other side. Aah. ${ }^{24}$

The war brought with it new forms of corporeal and imaginative travel ${ }^{25}$ for both men and women. Especially in the case of female combatants, the war initiated a new gendered mobility that also played a part in extending their geographical imagination. In their childhood, though the girls and women had heard travel stories from their fathers and other male members of their families, they had themselves lived in the relatively small sphere of their homes and nearby villages while men traveled long distances for work purposes (see the previous chapter). The Ayaawo, as I already mentioned, were involved in long-distance trade, dating back before the arrival of the Portuguese. Yohanna B. Abdallah, in his history of the Yaawo people from 1919, even claims that it was traveling that defined a "Yao man." As he writes, "Should anybody say, "I am a Yao,' not having visited other countries, he is not a Yao at all, and everybody laughs at him, saying, "This is a woman, not a man." ${ }^{26}$ In my interviews with male elders, many of them would talk about traveling great distances for work; they would remember, for instance, going for three-month expeditions on foot to sell tobacco in Ciwambo at the coast of Quelimane by the Indian Ocean; going as migrant laborers to work in the gold mines in "Joyni," in the Rand area close to Johannesburg in South Africa; or the sisal plantations of Tanganyika; or going to work as "houseboys" in Southern Rhodesia. ${ }^{27}$ Even many of the ex-combatant men that I interviewed had the experience of traveling beyond the borders of the Portuguese territory before the start of the war. This is not to say that women were static and men mobile, but that women's sphere of geographical movement was different, and it changed significantly during the war. 


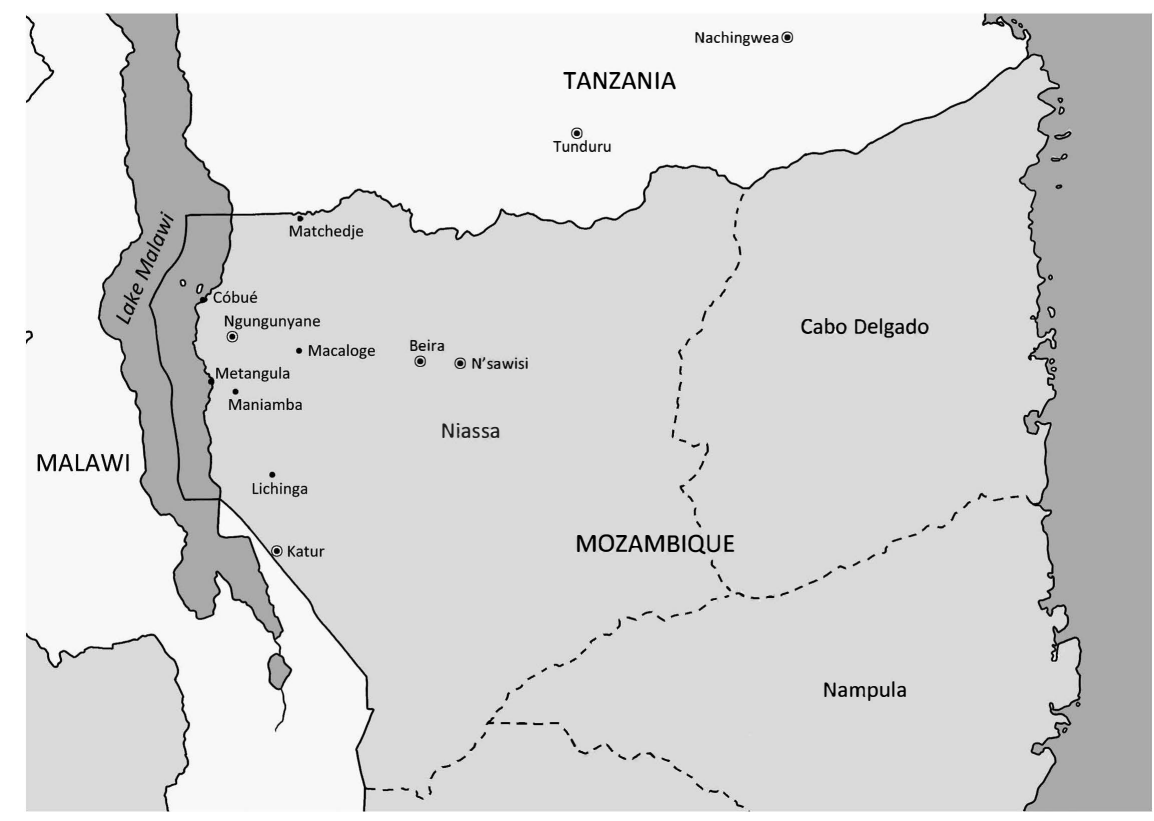

Map 3.1 FRELIMO's principal military bases in Niassa during the war (marked with white circles on the map)

Source: Map by Noora Katto

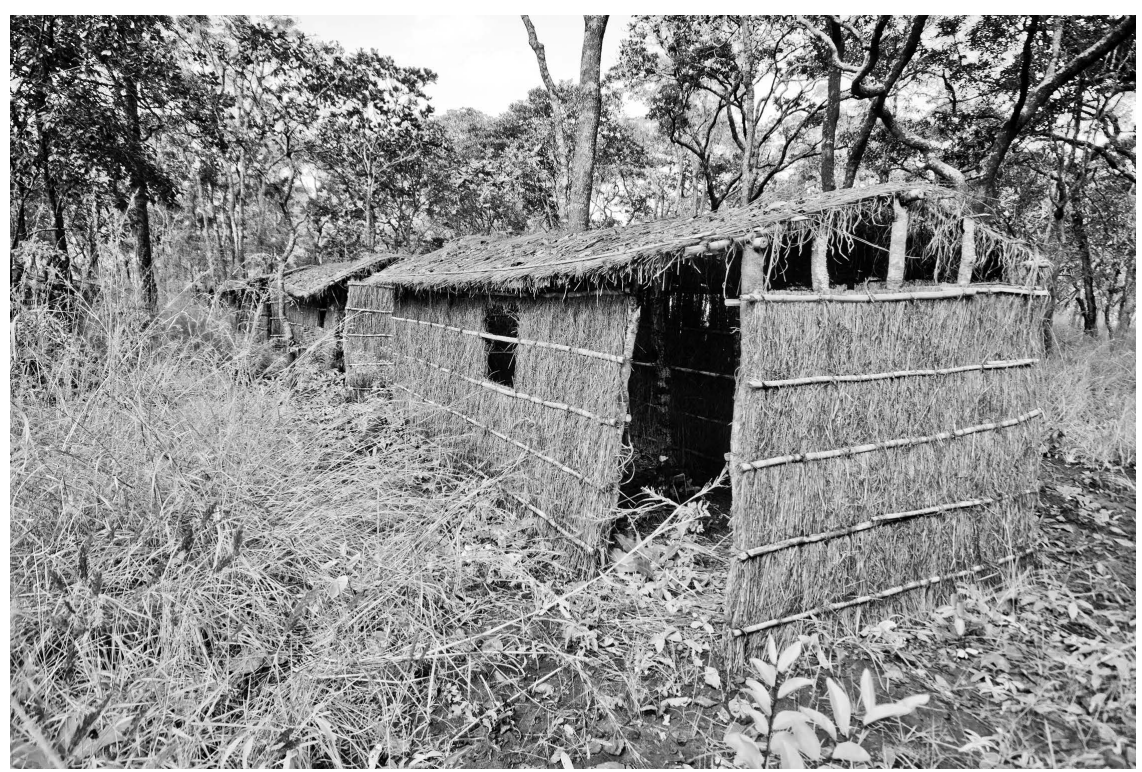

Figure 3.1 The "historical locale" of Base Beira in N'kalapa, Mavago, 2014 
The landscapes of Niassa have always been on the move, as I have tried to show. They have been shaped through the movement of people, goods, and ideas. The liberation struggle, moreover, marked a new epoch in its transformation. During the war, the landscape was constantly changing through the moving locations of bases and the shifting boundaries of the semiliberated and liberated zones. ${ }^{28}$ For instance, Fátima Aquili, commander of the DF in the region of Niassa Austral, describes how the guerrillas never stayed in one place for long:

We didn't have our own place to STAY. Today here, after tomorrow there, after tomorrow there. Always! Like that. We didn't have our own place. Always moving. ${ }^{29}$

The soldiers' cabanas (or makeshift grass shacks) were built and rebuilt many times over as bases were discovered by the enemy, destroyed, and soldiers were forced to relocate. Bases also moved when security intelligence suggested that the location of the base had been compromised, and there was a chance that the colonial army knew their coordinates. If possible, the new base would be set up relatively close to the old base for FRELIMO not to lose hold of its territory. Often, the bases took the name of the chief of that area, or a close-by river or mountain. ${ }^{30}$ Yet even despite moving about a lot, the names of the bases usually stayed the same, and thus some sense of continuity was maintained. In the following excerpt, Maria Ajaba speaks about her base, the Provincial Base of Ngungunhane (first established in the area of Chisindo in 1967) ${ }^{31}$ in Niassa Ocidental, where she mainly served during the war:

MARIA: So. It wasn't that ... you can count how many times. In one week, you could move three times. In one month, you might move four times ... because of the war. It wasn't one place. Ehm, I can't count HOW MANY times we moved. Not at all. It's many times. Yes. But always: Every place that we will visit ... it is Ngungunyane.

JONNA: Aah, okay, the name always-

MARIA: The name always stays. ${ }^{32}$

It is noteworthy that Maria uses the verb "visiting" to describe her relation to the different places where she, along with her colleagues, set up camp during the war. This corresponds with Fátima's expression of not having one's “own place to stay." During missions or when fleeing, shelter was sought under trees; at the bases, cabanas acted as temporary shelters. The first years of the war and then 1971, the year of Kaúlza de Arriaga's campaign, were in many interviews described as the periods of most hectic movement. ${ }^{33}$ Aerial bombings were very intense during those times. Otherwise, the intensity of war movement varied between regions and bases. When the bombings were less frequent in certain areas, some DFs spoke of feeling more settled down at the bases where they were living. Maria Yassine, for instance, spoke of a time when she felt "like at the village" ("mpela kumuri roni"). ${ }^{34}$ 


\section{Haptic sensing}

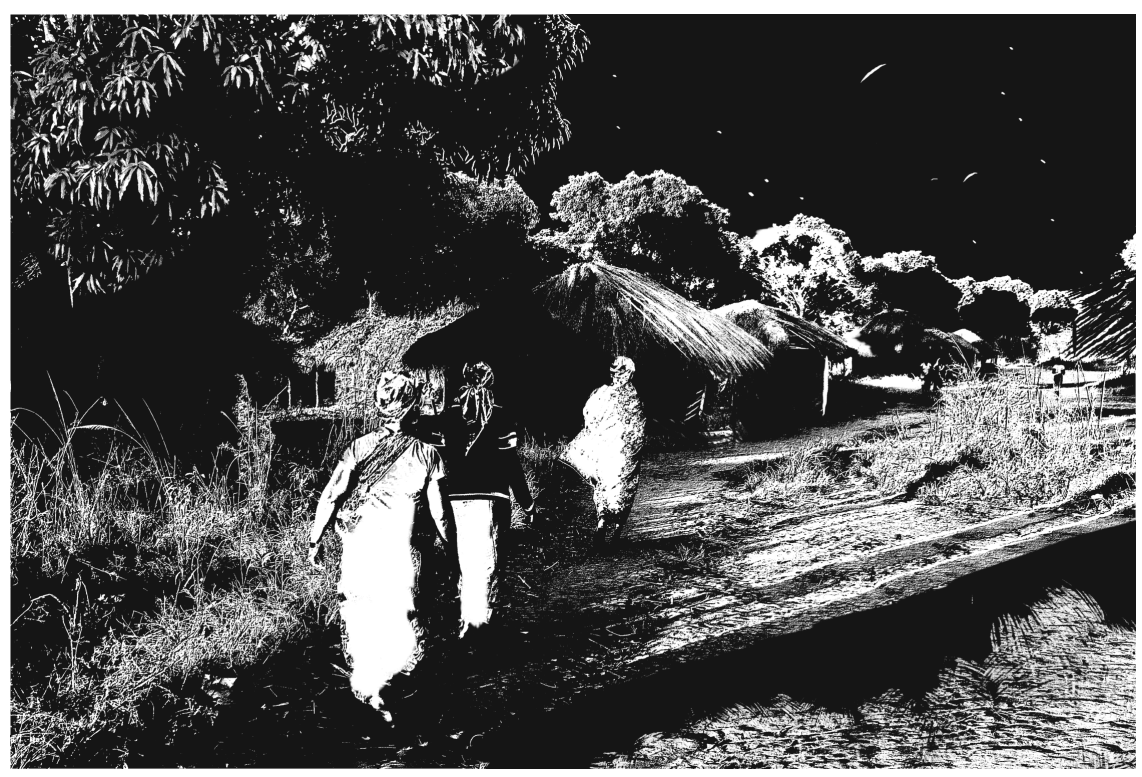

Figure 3.2 Retracing old footsteps and making new paths in Mavago

Source: Illustration by Mikko Kankaanpää

Walking through Mavago town one late afternoon, Lúcia and Helena stop to show me an old guerrilla footpath that used to pass through the area. During the struggle, the trail led all the way to Base N'sawisi. A big tree still standing in the village close to the main road used to signal a turn in the direction of the path. No population lived here at the time, but the Portuguese often patrolled in the area, so it was considered a dangerous location. While we continue through the village, the two women start making fun of how the guerrilla fighters used to walk during their treks through the bush. Describing the movement as that of a "crazy person," they theatrically perform the jerky movements of their march: convulsively turning their heads in the different directions; with eyes watchfully wide open; and ears extended and alert; stopping at abrupt intervals to more fully tune in to their surroundings, but also at the same time to hide their own presence in the landscape. For me, their body language evokes a sense of the nervous fear they must have felt at the time. The performance, moreover, points to the guerrillas' necessarily multisensory engagement with the environment. Visual perception, though an important sense, was closely tied to a haptic way of sensing. Sometimes, as I was told, the guerrillas had to march in the moonlight to gain time and distance. On the same trip in Mavago, Helena tells a story of how the DFs sometimes had to feel their way in the dark, all the while carrying heavy loads on their heads. Helena starts telling this story as we are sitting in the candlelight after dinner one evening. It is "this darkness," she claims, that makes her remember 
how the DFs sometimes had to navigate through the dark "bush," not seeing where they were stepping. Laughingly, she recounts how they could not even cover a short distance (like the few meters from where we are seated to the central road that cuts through Mavago town) without a DF falling and startling everyone. "IIH! What was that?" Helena mimics someone whispering in an alarmed voice. And a moment later, "I thought it was the enemy!" she playfully impersonates a relieved voice exclaim. This, as Helena narrates, is met with collective bursts of laughter as the DFs quickly perceive the humor of the nonthreatening situation.

These two stories speak of the interrelatedness of the different modes of sensing in the practice of guerrilla life. In Western philosophical tradition since Aristotle, the senses have been conceptualized through the model of the five senses, each existing separately and transmitting different information. ${ }^{35}$ In this thinking, vision has been positioned, as Juhani Pallasmaa writes, as the "noblest of senses." ${ }^{36}$ And it is through this tradition that we still continue to understand and use the eye as the "organ of distance and separation." 37 This way of seeing also resonates with Moiane's words at the beginning of this chapter, which speaks of the view from a "superior vantage-point." Yet my interviews with ex-combatants in Niassa suggests an understanding of visual perception, not as a separating sense, but one that also plays a role in engaging one in a haptic relationship with the landscape. The organization of the sensorium, of course, varies widely across different cultures and times. ${ }^{38}$ According to Tim Ingold, ethnographic research suggests, for instance, that "vision" and "hearing" are not "radically opposed" in non-Western societies but blend into each other. ${ }^{39}$ Though this might appear to be a rather generalizing argument, I think it holds true when examining the most commonly used language of perception in my interview material. The Ciyaawo verb "kuwona," which means "to see, experience, feel," was used frequently by my interviewees (in Portuguese the verb "ver" was used in a similar way, though "sentir" was also used to talk about feeling). ${ }^{40}$ Though "kuwona" emphasizes visual perception in some contexts, it usually refers to a multisensory participatory engagement in an event or place. ${ }^{41}$ This echoes with Ingold's argument. Moreover, Ingold usefully argues for "vision" to be reconceptualized as "nonrepresentational, a matter of watching rather than seeing." 42 In the interview accounts, knowing, and especially historical knowledge, was often linked to participatory perception. Often, the women expressed that they could not speak of other historical narratives, such as the guerras antigas (Ciyaawo: ngondo ya kala-kala; old wars) of their elders or of the civil war (e.g., guerra da RENAMO; ngondo ja a-Ncakama), as those were events they had not "seen, experienced, felt" (kuwona). Instead, they could tell about the liberation struggle, as that was the war in which they had participated. The DFs' accounts of the war, as I suggest, emphasize a "haptic" way of knowing that places the body at its center.

Haptic refers here to the sensuous contact between body and world. The "haptic system" was famously defined by James J. Gibson as "the sensibility of the individual to the world adjacent to his[/their] body by the use of his[/their] body." ${ }^{43}$ Haptic is a broader concept than the sense of touch (or tactile perception). Touch is associated with sensations felt through the skin, whereas haptic perception synchronizes movement and touch. Paul Rodaway defines haptics as 
"the tactile receptivity of the skin, the movement of the body parts and the locomotion of the whole body through the environment." ${ }^{44}$ According to Gibson, the haptic system integrates kinesthesia, proprioception, and the vestibular system. This emphasizes the synthesis of the senses in the act of perception. ${ }^{45}$ The senses of balance and bodily position are, for instance, not noted as separate systems of perception until something goes wrong in the body or something in the environment puts the body out of equilibrium. For instance, the story in the beginning of this section shows how the DFs' sense of balance and sense of feeling with their feet was unsettled by the darkness that restricted their seeing. Haptic perception is essentially multisensory. ${ }^{46}$ Here, I understand "haptic" in a broad way to mean all the various sensory experiences that become integrated through the movement of the body as it engages with the world. ${ }^{47}$ Our senses thus put us "in touch" with the world and relate us to other sensing bodies. Moreover, touching involves a relation of reciprocity with other people and the natural environment; we cannot touch without being touched. ${ }^{48}$ In the following two subchapters, I will first look at the haptic experience of the bush, focusing on how the "bush" in different ways "touched" the bodies of the ex-combatants, leaving its "unforgettable" marks in their memories. In the final subchapter, I examine the remembered experience of the sound ambient of the war and how this also constituted part of the haptic spatial experience of the "bush" during the war.

\section{Violence of the "Bush"}

"During war," Inge Brinkman fittingly writes, "the meaning of landscape elements changes; the phenomenological nature of things is altered." 49 In the interview accounts, the bush and its elements were sometimes perceived as acting as accomplices in the violence inflicted by "Portuguese colonialism." In the following extract, Helena speaks of her experience of the Portuguese attack on the Lugwalo base, where she was based at the time.

It is where I was wounded, there at that base ... where I caught this bullet here [touches her knee] . . a at that base of Lugwalo. Actually . . . it is like this [draws on the ground while talking] mountain, like this mountain, like this mountain, like this mountain. So the trail from Tanzania came like this. Mmm. So when the helicopters arrive, they landed there in the middle. The people had no way to escape. That's why at that base many people were wounded and many died. ${ }^{50}$

In another context, Helena speaks of mountains being her "enemy number one." She tells me of her dislike as we are climbing a small steep-sided hill in Matchedje (also known as II Congresso), an otherwise flat area near the Rovuma River by the Tanzanian border. As I laughingly acknowledge her comment, she commences to speak about her memories of Mount Matekenya in N'sawisi. This mountain, as she explains, gave her a lot of trouble during the war. She had to cross it every time traveling to and fro between FRELIMO's central base, Base 
N'sawisi, and the other bases where she was sent on missions. Also, later on, the FRELIMO crèche that was placed in her command was located near the top of this mountain. Helena speaks of how the guerrillas had to climb Matekenya with all their war material, food, and other luggage on their heads and their weapons slung around their necks hanging in front of their bodies. The climb would take several hours; after which, everyone was exhausted. For Helena, the physical exertion required to march up its slopes continues to be a strongly unpleasant haptic memory. Yet while the mountains in her first account were perceived as being against them (the guerrillas), impeding their escape from the havoc of the aerial bombings; in this narrative, the mountains act as their allies. The Portuguese troops never managed to make it up to the top of Mount Matekenya; it proved too much of an obstacle for them, as Helena argues.

The body-bush relationship is best described as an uneasy alliance. Though the bush brought invisibility and refuge during the war by providing hiding places, at the same time, it was experienced as dangerous and hostile. Even before the war, the bush was not considered the natural habitat of people but of animals; people would clear bush, build houses, and cultivate crops in order to expand their living environment. In the interviews, the "bush" is often categorically construed as the opposite of a livable space (I will come back to this in Part III). It was a space through which people traveled, and people often spoke of the suffering of those travels. Still, Brinkman makes the important point that even though the bush was perceived as dangerous, it still formed part of the people's "sphere of influence." But the war changed in many ways the guerrillas' relationship with the bush and, as I suggest, their sense of influence over this space. During war, boundaries, for instance, between human and animal spaces were blurred. In her account, Helena Caisse compares the guerrillas' life in the bush to the life of animals. The DFs spoke much about how during the war they became intruders into spaces that were considered to belong to animals. It was often considered miraculous that nothing happened, even though they would seek refuge in caves believed to be inhabited by big snakes. Traditionally, the territorial chiefs have a responsibilitythrough the offering of the sacred flour mbopesi, and occasionally, the use of protective sorcery - to ensure the well-being of their populations. As Ce-N'talika (a chief who fought with FRELIMO in the war) described, through protective sorcery (Ciyaawo: matipwi), chiefs can transform an inhabitable or unworkable land, or bush, into a place where people can live and work and prosper and not be hurt by wild animals. ${ }^{52}$ Relations between the guerrilla fighters and the "bush" were also importantly mediated through these kinds of spiritual practices, and sorcery was used during the war for the protection of FRELIMO. During the war, for instance, the old Ngoni chief Ce-Diseko in N'sawisi, who was remembered as having "very strong medicine," was called upon to shield the guerrillas from the Portuguese troops. ${ }^{53}$ This protective sorcery, as I was told by Helena and others who had experienced this event, made the whole camp invisible, and the enemy soldiers walked right through without ever discovering it.

Many DFs spoke of the painful experience of being completely vulnerable to the elements of nature, also weather conditions. In the interviews, when I asked which 
period of the war was remembered as the toughest, most people would immediately mention the rainy season. As they explained, the rainy season was when the hectic movement of fleeing and having to rebuild one's cabanas hurt the most. The negative sensation of getting thoroughly wet was mentioned in many interview accounts; sometimes this happened when having to plunge into the water when crossing a river, other times because of rain, as the following accounts show.

HELENA CAISSE: WE REMEMBER. I REMEMBER. Eeh. . . . I remember. Yeah, we were in the bush. We slept in places that didn't have houses ... under trees. Yeah, we ... used to walk from morning ... The wet blanket we put in the backpack. Yeah, we arrived in another place "let's spread it out" and we spread it out. Like this ... the years passed. Yeah, we nowadays - we are living like animals. ${ }^{54}$

FÁTIMA ISSA CHIPANDE: What we saw/experienced hurting a lot was the rainy season. We experienced pain when the Portuguese left us in chaos ... running into the forest, and the rain catching us ... and it was only to get wet. There is no place - to say here I will stay to hide myself. The way of stopping-let's stay under this here tree ... until the rain stops. That hurt us. ${ }^{55}$

The weather patterns also shaped movement in the landscape, and the guerrillas had to learn to navigate the terrain in all its different seasons. Ingold writes of weather being "an all-enveloping infusion which steeps into his [/a person's] entire being," which makes movement in the landscape always "movement through the weather-world." ${ }^{56}$ This resonates strongly with Helena Caisse's and Fátima Issa Chipande's words. The seasonal changes influenced the haptic experience of the "bush," with the rainy season enhancing its hurtful touch. The weather also influenced the guerrillas' sense of the temporality of the war. The narratives show how time was often experienced as evolving in a cyclical manner, especially during tougher periods when the end of war seemed totally unimaginable.

"Running-running" (Portuguese: corrrer-correr; Ciyaawo: kuwutukawutuka) was the expression often used referring to one's kinesthetic experience of war. This expression connotes nonending, directionless movement. The most traumatic experiences of guerrilla life were often narrated as that of hectically fleeing aerial bombardments, escaping the Portuguese ground troops, and the chaos of cross fire. Moreover, the DFs would tell many stories of the experienced horror of almost dropping their children, or momentarily losing them, when having to run for cover. During the worst periods of intense bombings, people used to sleep in their clothes and with their shoes on their feet. Also, although combat was not an equally shared experience between male and female combatants, ${ }^{57}$ it must be recognized that in guerrilla warfare, the line of combat is often blurry. Most of the DFs, like Madiatu Issa, spoke of how they "couldn't lie" and say that they had been wounded by bullets. Instead, these women spoke of being hurt by the things of the bush: tree branches, rocks, razor sharp grass, and thorns, as the following examples show. 
TERESA MACOTOA: This side here, tree thorns [touches her leg in several places] ... there, there. There, thorns pricking ... here [touches the inner part of her arm close to the elbow] this side here. Here . . . the wood entered there, went through here $\ldots$ all this skin coming off from here. ${ }^{58}$

HELENA CAISSE: Because in the group of men, I hurt myself in the tree/bush thorns. (...) Because in other [places] going where there are no-there are no paths, only bush. ${ }^{59}$

MADIATU ISSA: That it was of a bullet I won't lie, but a thorn wounded me here [touches her thigh] . . . in Lugwalo. ${ }^{60}$

As the women remembered, in their terrified attempts to flee the havoc and death caused by the bombardments - seeking a place to hide-they would plunge into the bush, where thorns and tree branches would tear into their flesh. The landscape was not a backdrop against which violent acts were perpetrated; the relation between body and landscape was often characterized by a violent tactility.

Maria Issa speaks of how the year that Arriaga initiated his campaign, and started to build his roads into the bush, ${ }^{61}$ was the year that really hurt. During these times, there was no place to hide in the bush. They did not have time to find food, only drink water, and move. As she describes,

The year that the war was very difficult, yes, was the year that Arriaga entered. Yeah, as soon as that Arriaga came ... he came with force. Where there were no roads even like that he passed. So this war hurt a lot the year that Arriaga came. There was no place where to hide yourself, plane above. Here on the ground: those of the ground [ground troops]. Just sit back and watch the planes there. There, they landed, the troops they are on the ground, the plane above. Now there is no way of doing anything, not even to eat. . . We didn't eat. We only moved. We only drank water. Other times not even food we didn't have. We just lived as if ... we are not people. The war like this hurt because people suffered ... the war hurt a lot.

The experience of hunger was one of the most intense feelings remembered and often spoken about during the interviews. The guerrillas ate and drank whatever they could find. Often, they would focus on drinking water to fill their stomachs, many times "bad" dirty water. Teresa speaks of her experience in the following interview excerpt:

Uhmm ... and we did that there ... and we suffered that there, that way of doing that. To eat, we ate with suffering.... When you find water ... [continues in very low voice] that the pigs bathed in, we drank. For us to have strength. Arriving at the machambas of some people, we just showed up. There wasn't time, there was no time to get food. We took manioc. Even peanuts we divided four and four with those in the group. Four for 
one [person], four for another [person], four for another. So that we can do what?... Drink water.

She continues further:

We didn't choose the food ... starting with the animals. Now we are saying: " $\underline{A h}$, I don't eat pig meat." " $\underline{A h}$, we, that thing we don't eat- $\underline{\text { ahh }}$, monkey." We, that's what we did ... in our work group for our work. Coming across a monkey, killing it, eating. Like that we got ugadi... Coming across a lion, killing it, like that we got ugadi. ${ }^{62}$

Many religious practices were not upheld during the war. Although identifying as Muslims, the women I interviewed spoke of how during the war they were not able to practice the different rituals of their religion. It was not banned by FRELIMO (at least this was not mentioned), but the war movement made it impossible. As Teresa's account shows, suffering from hunger, they did not have the luxury of following the Islamic dietary restrictions, even though they were considered important for their religious identity as Muslim Ayaawo. Many DFs, for instance, spoke of how before the war, their parents had refused to send them to school at the missions for the fear that they would "eat pork meat."

Hunger was a serious issue during the war. Niassa, which was already Mozambique's least densely inhabited province, became practically uninhabited when the war started. ${ }^{63}$ Ex-military commander Ntoto Nihia speaks of how the guerrillas could walk 30 to $40 \mathrm{~km}$ without seeing settlements. ${ }^{64}$ According to him, this made movement difficult for both the guerrillas and the Portuguese army. The guerrillas depended on the civilian population for support. The intense bombings and lack of food, however, caused masses of people to flee to Tanzania from the eastern and western regions and to Malawi from the region of Katur. Cultivation of crops was extremely challenging during the first three to four years of the struggle in Niassa, and the population as well as the guerrillas suffered from hunger. ${ }^{65}$ The year 1968 was especially difficult; many people died of hunger, and guerrillas deserted en masse. ${ }^{66}$ Several high-ranking officers during the liberation struggle who served in Niassa spoke of the challenge of mobilizing the population to cultivate and not flee the war areas. Bernardo Moisés Goy-Goy, for instance, commander of Base N'sawisi at the time, accounts that an order was issued by Samora Machel that the cultivation of crops was to be one of the priorities alongside fighting and studying. ${ }^{67}$ Also, the guerrillas, along with the population, had to develop new strategies of how to cultivate and safeguard food during the wartime. This involved cultivating on dispersed small fields partially under the cover of trees, and the harvested food had to be hidden in various locations away from the fields. ${ }^{68}$ Especially in food production, the relationship between the population and the guerrilla fighters was central. Political mobilization played a crucial role in the war. According to the classic principles of guerrilla warfare, the guerrilla fighters are like "fish in the water." ${ }^{\circ}$ This means that they are totally dependent on the 
civilian population for their survival and cannot risk having bad relations. As Rosa Mustaffa's account on page 99 shows, the mobilization of the population was an important task of the DFs. Ex-general Osvaldo Assahel Tazama argues that the principal task of the DF was to mobilize and speak of the "necessity of feeding the guerrillas." 70

In the years that neither the population nor the guerrillas had time to cultivate, many spoke of how they were forced to eat roots and other "things that didn't have names" ("kudya yicindu yangadi dina"). Rosa Mustaffa speaks of how they ate "things of the bush" (Portuguese: coisas do mato; Ciyaawo: yicindu ya mwitinji) that were not suitable for human consumption. As she explains, during the war, they ate just to "get rid of the feeling of hunger." She also tells of how they would test try just about anything that happened upon their path. As she remembers, "It was enough to confirm that it wasn't bitter, I don't know what, we took it as food for us to aliment our bodies." ${ }^{71}$ Generally, food during the war is not remembered as having taste/smell; it did not animate one's senses in a positive way. Food also became associated with danger; the "things of the bush" could kill a person. In the following excerpt, Helena speaks of how they cooked these dangerous things that they used as food during the war:

We ate unknown fruits ... that even now ... that we are seeing that "eh, but this here we ate." These days, a person to take that and eat- dies. The person doesn't live... But that time of the war we ate. BUT . . the way of cooking it is different. We cooked another way. These people that are now picking [those fruits] are cooking another way. Because we cooked ... five hours putting that pot on the fire, with that fruit. To come and eat . . at

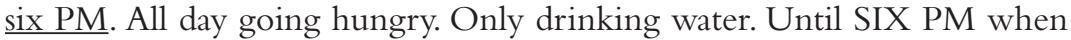
you will hear the whistle. "Ih, let's go there to receive food." ONLY TO GO and receive that fruit. But that fruit ... we knew that this here KILLS. But we cooked with ash. Taking that ash from the fire ... then putting there, in the pot. After boiling it, throwing away that water. Adding new water. Taking more ash, putting there. ALL DAY like this ... to come and eat at six PM. ${ }^{72}$

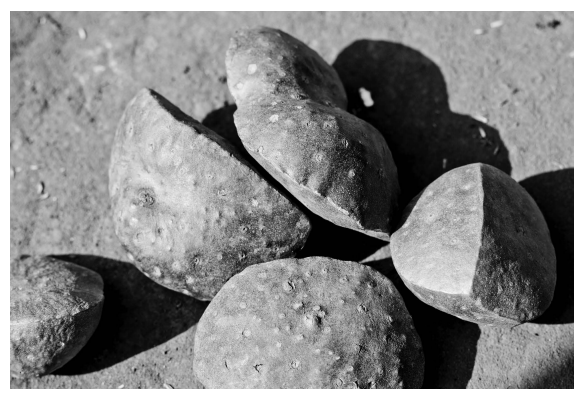

Figure 3.3 Deadly fruits, Mavago, 2013
I was told that during the war, many people died because of eating "fruits" that looked identical to the ones in the picture. The ones people grow in their gardens (called citungula, pl. yitungula) are good for eating, but the ones of the bush (didiga, pl. madiga) are deadly poisonous. 
The bush also had many edible things that people knew by names (e.g., a green leafy vegetable called "nkuta," the fruits "ndawa" and "maruku," honey "wuci," and mushrooms "wuwari"). ${ }^{73}$ At times, in other areas, game meat was the guerrillas' principal source of nourishment. ${ }^{74}$ Though, as I was told, this also posed challenges, as the hunter had to go far away from the base and the population, so as not to attract the attention of the enemy to their location.

\section{Sounds and sensations}

The war landscape was also intensely felt through the ears. ${ }^{75}$ Tuning in to the sound ambient was an integral part of the guerrillas' haptic relationship with the environment. In the women's accounts, the war was often remembered by its violently intrusive sounds. The "ambient noise background" Barry Truax's term to describe the indistinct background sounds of the forest/ bush-could at any moment be disrupted by the warning signals of planes and helicopters or the explosive sounds of bombs and gunfire. These sounds were emotionally remembered and often imitated in the narratives. ${ }^{77}$

In the following extract, Maria Mota speaks of her memory of her bodily feelings and emotional responses when finally hearing and experiencing silence as opposed to the already normalized sounds of war.

There was a time to be happy ... because our happiness we used to become happy the following way: If there was a time that it was silent [nje], not hearing the planes "wuuuuu," not hearing there "taa-taa," that time the blood was content/happy/calm. Yes, we conformed saying that now we are from right here. Now the time that they arrived ... maybe the planes "wuu-wuuwuu-wu." Ah, like that the blood no longer was content because we became very sad and said that the plane is coming ... maybe it will be me [who will be killed] ... maybe someone else. Like that there was a lot of sadness. ${ }^{78}$

In Ciyaawo, "nje" is an ideophone that evokes a sense of tranquil silence. ${ }^{79}$ Ideophones as expressive words are, as Mark Dingemanse writes, "intimately tied to perception and sensation." 80 "Nje" has a positive connotation, and the women often used it to emphasize contrast between peace (also emotional calmness) and the intrusive and violent sounds of war, such as the noise of planes ("wuuuuu"; "wuu-wuu-wuu”) and of shooting ("taa-taa"). In Maria's narrative, these sounds are closely tied to bodily and emotional responses. She remembers the intense happiness that "silence" evoked in her. Also, the physical sensation of the pulsing of the blood in one's body was interlinked with this emotional response. As our conversation continues, Maria talks of how during this quieter time (probably toward the end of the war), the guerrillas even allowed the population to perform siyala (derived from Arabic ziyarah)-the celebration commemorating the anniversary of the founder of the tariqa (the Sufi way).

Because another time we became happy .... and ... even the people ... of siyala those of siyala. It was possible to do siyala. But they called the 
comrades [soldiers of FRELIMO] to stand there [in guard], to stand there [in guard] as we did siyala until the break of dawn. This made us happy because those planes didn't exist. They were resting. ${ }^{81}$

The connection Maria makes between silence ("nje") and siyala furthers an understanding of the meaning of silence as associated with the rhythms of social and religious life. During the war, many religious practices were put on hold-Islamic dietary regulations, daily prayers, fasting during the month of Ramadan. Loud festivities like siyala, involving the Sufi ritual of sikiri (from Arabic dhikr) — all night long chanting of Islamic texts and prayers accompanied by singing and the intensive stomping sounds of the male dancers' feet on the ground-were banned. ${ }^{82}$ Also, initiation ceremonies were performed in quiet. ${ }^{83}$ Many DFs spoke of undergoing (female) initiation (nsoondo) younger than what was customary (not having yet reached puberty) as news about the war started spreading in their communities from 1965 onward. One DF, Lúcia Abdala, emphasized how “one couldn't even play the drum" when she was initiated in the middle of the war. ${ }^{84}$ Moreover, as Lúcia describes life during the first years of the war (when she was still living with the population in the proximity of a FRELIMO military camp), they would get up in the mornings, put the fires out, and stay in silence "nuuh" ("moto turimile .. uwe tudi kwele-ko nuuh"). ${ }^{85}$ Both the combatants and the population living in the bush were supposed to blend into the acoustic environment of the bush to avoid being detected by the enemy planes. The soundscape of the war was characterized by an uneasy, nervous silence ("nuuh"), which at any moment could be disrupted by the intrusive sounds of war.

The ex-combatants spoke of becoming accustomed to these sounds, and their narratives also attested to how they discovered their specific rhythms and cycles. For instance, Helena remembered how the Portuguese planes liked to arrive early in the morning to catch them still sleeping; also, if the planes had not arrived by noon, it meant that they could rest that day. Moreover, this rhythm was not consistent throughout the entire war, and there were years in which these sonic intrusions were frequent and other times when they were more sporadic. ${ }^{86}$ In the interviews, the ex-combatants' experience of time in the war years is also narrated through these changes in the soundscape. ${ }^{87}$ The beginning of the war was often characterized by more intensive movement of planes (like Lúcia also described); this was followed by an interval of a quieter time, and then in 1970, as Kaúlza de Arriaga took over as commander of the colonial forces in Mozambique, the terrifying sound of helicopters dominated the soundscape. Arriaga's offensive lasted close to a year and caused a lot of destruction and human suffering. ${ }^{88}$ According to Brigadier Goy-Goy, the "bombardments were frequent and intense," and as he describes, after the bombings, troops would descend from the helicopter to "continue the bloodshed," also burning and destroying people's goods and possessions. ${ }^{89}$ Those years are commonly remembered as the toughest years of the war when many bases were destroyed, many guerrillas deserted, and a lot of the supporting population 


\section{Violent liberation}

fled to the neighboring countries, Tanzania and Malawi. After this period, the war quietened down again in some areas, and the guerrillas even managed to cultivate machambas near the bases. It was in this quieter time that, in Maria's narrative, the guerrillas allowed the population to perform siyala, an important "soundmark" feature in the yearly religious cycle of the Muslim Ayaawo. ${ }^{91}$ As exemplified in Maria's account, these well-recognized acoustic rhythms also affected inner sensations of peace and even a sense of attachment to place. As Maria remembers, "We conformed saying that now we are from right here." (Maria Yassine speaks of a similar experience of feeling "like at the village" on page 101.) In the following chapter, I further examine the sounds of inner feelings and how silence acquires a very different kind of connotation. As I will show, "peace" as an embodied experience involves a continuous negotiation over the senses and meanings of past violence. In the ex-combatants' accounts, FRELIMO's political discourse is closely tied to bodily ways of knowing.

\section{Notes}

1 "José Phahlane Moyane," in Protagonistas da luta de libertação nacional, comp. and ed. Ana Bouene Mussanhane (Maputo: Marimbique, 2012), 464. Mussanhane's book is a collection of the testimonial accounts of forty-three ex-combatants of the liberation struggle. Her interviewees were, for instance, former guerrilla fighters, clandestine fighters, FRELIMO representatives in Tanzania, FRELIMO students, and ex-political prisoners.

2 For example, interview with Eduardo Silva Nihia, Maputo, July 2, 2014; Moiane, Memórias de um guerrilheiro.

3 José Phahlane Moiane, lieutenant-general in reserve at the Mozambican military forces, received his military training in Bagamoio, Tanzania, and in China in 1963. In Niassa, he served as adjunct chief of military operations and sabotage from March 1965 to June 1965 and then as chief of military operations of Niassa. Moiane served in this position until 1967 when he was transferred to Tete. Raimundo, "Frente do Niassa," 486-488.

4 The term "landscape" was generally never used by my interviewees.

5 Interview with Helena Baide, Lichinga, May 23, 2014.

6 Usually, "mwitinji" (in the bush) was used in Ciyaawo to refer to the guerrilla fighters' lived environment during the war, though on a few occasions "mu'wukweti" (in the forest) was also used. In Portuguese, "no mato" (in the bush) was mostly used and on a few occasions "na floresta" (in the forest).

7 Inge Brinkman makes this point about southeastern Angola, but it holds equally true for Niassa. "Town, Village and Bush: War and Cultural Landscapes in South-Eastern Angola (1966-2002)," Afrika Focus 25, no. 2 (2012): 31-43; "Landscape and Nostalgia: Angolan Refugees in Namibia Remembering Home and Forced Removals," in African Landscapes, 275-294.

8 By the early 1970s, almost 50 percent of the African population in Cabo Delgado and Niassa and 60 percent in Tete had been forcefully moved. Isaacman and Isaacman, Colonialism to Revolution, 101. See also João M. Cabrita, Mozambique: The Tortuous Road to Democracy (Basingstoke: Palgrave Macmillan, 2000), 32. These numbers must be measured against the fact that with the advancement of the fighting into their home areas, most of the population of Niassa took flight into neighboring countries. For example, according to colonial records, by 1966, the inhabitants of Sanga had reduced from 22,580 to 5,627. Galli, Peoples' Spaces, 35. Still, all those who fled their villages did not leave Mozambique; rather, entire village populations fled colonial control into the 
bush. Some of the people joined FRELIMO freely while others were captured. See also Funada-Classen, Origins of War, 303.

9 dos Santos, Desconhecido Niassa, 175-183.

10 The roads were constructed using forced labor. Later, those who failed to pay their taxes were forcefully recruited to do this work.

11 His name was Ce-Bonomadi, and he ruled from 1885 to 1903. Medeiros, História de Cabo Delgado e do Niassa, 88. On the oral histories about the Mataka dynasties, see also Lúcia Laurentina Omar and Alexandre António, As Dinastias Mataaka (Sec. XIV-XX) (Maputo: ARPAC-Instituto de Investigação Sócio-Cultural, 2004).

12 Interview with Asigale N'talika Mataka, Mavago district, May 10, 2013.

13 Their dynasties were much weaker. They also suffered from declining trade. See also Liazzat Bonate, "Roots of Diversity in Mozambican Islam," Lusotopie 14, no. 1 (2007): 138.

14 Medeiros, História de Cabo Delgado e do Niassa, 91.

15 Tenente Valadim was a Portuguese commander who died in an attack against Mataka III in 1890. Medeiros, História de Cabo Delgado e do Niassa, 89.

16 See also Silveira da Costa, Niassa visto por dentro, 44-45.

17 dos Santos, Desconhecido Niassa, 182.

18 For example, "José Phahlane Moyane," 465.

19 Ibid.

20 Israel, "Formulaic Revolution,” 193.

21 Moiane, Memórias de um guerrilheiro, 57.

22 Inge Brinkman's research shows that this was also the case in the liberation war in Angola. Brinkman, "Routes and the War for Independence in Northern Angola (1961-74)," Canadian Journal of African Studies 40, no. 2 (2006): 216-218.

23 Tim Cresswell and Tunu Priya Uteng, "Gendered Mobilities: Towards a Holistic Understanding," in Gendered Mobilities, eds. Tanu Priya Uteng, and Tim Cresswell (Burlington, VT: Ashgate, 2008). Feminist geographers have long been making this point. See, e.g., Rachel Silvey, "Power, Difference and Mobility: Feminist Advances in Migration Studies," Progress in Human Geography 28, no. 4 (2004): 1-17.

24 Interview with Rosa Mustaffa, Muembe district, May 30, 2014.

25 See John Urry, “Connections," Environment and Planning D 22 (2004): 28. He separates between five types of mobilities: corporeal travel, physical movement of objects, imaginative travel, virtual travel, and communicative travel.

26 Abdallah, Yaos, 29.

27 For example, interviews with Jaime Kaukuya and Chehe Aji. Both of these men were close to one hundred years old.

28 In Niassa, while FRELIMO also had bases and military activity in the southern part of the province, its stronghold was in the very north of the province where it established its "liberated zones." The real extent of the liberated zones is not entirely clear. During the war, much of the population fled to the neighboring countries of Tanzania and Malawi. FRELIMO struggled with civilian support due to low population density. Moreover, it is unclear to what extent socioeconomic relations were transformed in these areas in Niassa. See also Adam, "Trick or Treat," 46-48.

29 Interview with Fátima Aquili, Lichinga, June 6, 2013.

30 See also Raimundo, "Frente do Niassa," 485.

31 Interview with Tito Brás Cassimo, Lichinga, June 19, 2014.

32 Interview with Maria Ajaba, Lichinga, August 18, 2013.

33 General Kaúlza de Arriaga organized a massive military campaign called the Gordian Knot Operation ("Operação Nó Górdio") that deployed up to 100 helicopters and 35,000 soldiers in northern Mozambique. Newitt, History of Mozambique, 531.

34 Interview with Maria Yassine, Lichinga, March 25, 2013.

35 Mark Paterson, The Senses of Touch: Haptics, Affects and Technologies (Oxford: Berg, 2007). Following the Kantian tradition, seeing and hearing have been more highly valued in the Western cultural hierarchy of the senses, as they have been linked to reason. 


\section{Violent liberation}

The proximal senses of smelling and touching were long discarded as too bodily and feminine.

36 Juhani Pallasmaa, The Eyes of The Skin: Architecture and the Senses (Chichester: WileyAcademy, 2005), 15.

37 Ibid., 46.

38 See, e.g., Guerts, Culture and the Senses.

39 Tim Ingold, The Perception of the Environment: Essays in Livelihood, Dwelling and Skill (London: Routledge, 2000), 156. See also Alexandra Y. Aikhenvald and Anne Storch, "Linguistic Expression of Perception and Cognition: A Typological Glimpse," in Perception and Cognition in Language and Culture, eds. Alexander Y. Aikhenvald and Anne Storch (Leiden: Brill, 2013), 1-45. Aikhenvald and Storch discuss how perception verbs in many languages across the world often have multiple meanings that cover a range of senses.

40 For examples, "kwa mwayiwonaga maregwe ga ndege rya kutula" ("when you felt/ experienced the noise of the planes landing") and "yakudya ngayiwona kunong'a" ("not feeling the taste of the food").

41 Another verb "kulola" means "to see, look, observe" (Portuguese: olhar) but in a nonparticipatory way; this was not used much in the interview material. Especially when linked to the body, "kuwona" refers to feeling (e.g., "nkwiwona mun'cilu mwenu-mo"). It is also used when talking about one's personal point of view, but even here "kuwona" is closely linked to haptic knowledge, the body being one's main point of reference.

42 Ingold, Perception of the Environment, 156. Laura U. Marks uses the notion of "haptic visuality" to work against the conceptualization of seeing as a disembodied act. Laura U. Marks, The Skin of the Film: Intercultural Cinema, Embodiment, and the Senses (Durham, NC: Duke University Press, 2000).

43 James J. Gibson, The Senses Considered as Perceptual Systems (London: Allen \& Unwin, 1968), 97.

44 Paul Rodaway, Sensuous Geographies: Body, Sense and Place (London: Routledge, 1994), 42.

45 See also Casey, "How to Get from Space to Place," 18.

46 Susanna Millar argues the importance of understanding the "inter-sensory connections between touch and movement and vision" in haptic perception. Millar,"Network Models for Haptic Perception," Infant Behavior \& Development 28, no. 3 (2005): 260.

47 Movement is, as Paterson argues, "the key process that integrates the senses in embodied perception." Senses of Touch, 21.

48 See Paterson et al., "Introduction: Placing Touch," 13; Manning, Politics of Touch. Dianne Chisholm introduces the notion "touching intimacy" to describe this relationship between the body and the world in the activity of climbing. "Climbing like a Girl," 30.

49 Brinkman, "Routes," 208.

50 Helena speaking in our interview with Fátima Assume, Muembe district, June 13, 2013. During Arriaga's campaign, the Portuguese military tactic was to have fighter planes first drop napalm bombs into the bush before helicopters brought ground troops into the area. For a description of Arriaga's military tactics, see Harry G. West, Kupilikula: Governance and the Invisible Realm in Mozambique (London: The University of Chicago Press, 2005), 145-146.

51 Brinkman, "Routes," 215.

52 Interview with Metarika Yakaya Mapulume (Ce-N'talika), N'sawisi, Mavago district, June 3,2014. Asigale N'talika Mataka also spoke of a medicine (n'tela; pl. mitela) made of lions and how in the past the chief Ce-Mataka together with the bibi used this medicine to create a protective force around the village as well as to vaccinate their population. Asigale argued that the current Ce-Mataka has neglected these duties of the old chiefs, and this is the reason for all the diseases that plague people. Interview with Asigale N'talika Mataka, Mavago sede, Mavago district, June 28, 2013.

53 Conversation with Helena Baide, Lichinga, April 9, 2016. See also West, Kupilikula, 150-163. West writes that according to his sources, FRELIMO actively prohibited the 
use of sorcery in Cabo Delgado during the war. Despite this, as he shows, sorcery continued as an important interpretive framework. In Niassa, none of my interviewees even mentioned FRELIMO speaking against the use of sorcery. Although Eduardo Nihia mentions one case in Niassa Oriental. See Nihia, M'toto, 132-133.

54 Interview with Helena Caisse, Sanga district, June 10, 2014.

55 Interview with Fátima Issa Chipande, Mavago district, June 27, 2013.

56 Tim Ingold, "Footprints through the Weather-World: Walking, Breathing, Knowing," Journal of the Royal Anthropological Institute 16, no. S1 (2010): 131.

57 Daniel Assahel Polela argues that later in the war, it was decided that women should not participate in combat. Polela, born in Niassa, served as vice-chief of the provincial command of Cabo Delgado and after 1972 as provincial commander of artillery in Niassa. "Daniel Assahel Polela," in Protagonistas, 287. However, based on my interviews, I think there were differences between bases and commanding officers.

58 Interview with Teresa Macotoa, Sanga district, June 7, 2014.

59 Interview with Helena Caisse, Sanga district, June 10, 2014.

60 Interview with Madiatu Issa, Sanga district, June 10, 2014.

61 See also Nihia, M'toto, 145.

62 Interview with Teresa Macotoa, Sanga district, June 7, 2014.

63 Moiane, Memórias de um guerrilheiro, 74. See also "Bernardo Moisés Goy-Goy," in Protagonistas, 222.

64 Interview with Eduardo Silva Nihia, Maputo, July 2, 2014; also “José Phahlane Moyane," 465-466.

65 Oficína de História, CEA, “A produção nas zonas libertadas," in Não vamos esquecer!: boletim informativo da oficina de história 4, ed. Yussuf Adam (Maputo: CEA, 1987), $24-28$.

66 Oficína de História, CEA, “A produção nas zonas libertadas.” Eduardo Nihia remembers that the worst time of hunger in Niassa Oriental was in the years 1967 and 1968. Eduardo Nihia quoted in Raimundo, "Frente do Niassa," 529. See also Nihia, M'toto, 135-136.

67 "Bernardo Moisés Goy-Goy," 222. Eduardo Nihia writes of how the population in Niassa Oriental could not manage to produce food due to heavy bombings in the beginning of 1968. At the time, Nihia held the position of commander of the regional base of Niassa Oriental. Nihia, M'toto, 135.

68 Oficína de História, CEA, "Resenha histórica sobre as zonas libertadas-a experiência da província do Niassa," in Não vamos esquecer!: boletim informativo da oficina de história 4, ed. Yussuf Adam (Maputo: CEA, 1987), 13-18.

69 For example, Moiane, Memórias de um guerrilheiro, 57.

70 "Osvaldo Assahel Tazama," in Protagonistas, 629. Female soldiers also worked more in food production than men.

71 Interview with Rosa Mustaffa, Muembe district, May 30, 2014.

72 Interview with Helena Baide, Lichinga, May 23, 2014.

73 Interview with Madalena Bitete, Lago district, July 30, 2013.

74 During the worst period of hunger in 1968, FRELIMO distributed more arms and ammunition to hunters so that they might help feed the guerrillas. Some of this meat was exchanged for other food products at the Tanzanian border. Also around this time, FRELIMO started receiving food aid from supportive countries. Oficína de História, CEA, “A produção nas zonas libertadas," 26.

75 Hearing should also be understood as being in synthesis with the other senses. For instance, Maria Ajaba uses the phrase "hearing the smell" ("ouvir o cheiro") as she talks of her memory of the distinct smells of the different weapons as they were fired. Interview with Maria Ajaba, Lichinga, June 19, 2014.

76 Barry Truax, Acoustic Communication (London: Ablex Publishing, 2001), 67.

77 As Paul Rodaway writes, sound is also experienced emotionally. Rodaway, Sensuous Geographies, 95. 


\section{Violent liberation}

78 Interview with Maria Mota, Lichinga, July 27, 2013.

79 It refers, for instance, to the clear sunrise with no perturbations. It does not refer to interior feelings but feelings of shared happiness and peace. Conversations with Bernardo Silajo Aubi, fieldwork notes, October 28, 2014, and April 17, 2016.

80 Mark Dingemanse, "Advances in the Cross-Linguistic Study of Ideophones," Language and Linguistics Compass 6 (2012): 666. See also Doreen Helen Klassen, "You Can't Have Silence with Your Palms Up: Ideophones, Gesture, and Iconicity in Zimbabwean Shona Women's Ngano (Storysong) Performance" (PhD diss., Indiana University, 1999).

81 Interview with Maria Mota, Lichinga, July 27, 2013.

82 Bonate, "Yao, Islam." Most of the women I interviewed identified themselves as being members of the Qadiriyah Sufi Order, locally known as Kardiya. Some spoke of being Sukuti (derived from Arabic sukut, silent) or Kadiyani. According to Liazzat Bonate, the Yaawo "adherents of Qadiriyah are divided between those who perform the noisy dhikr with drums and the quietists (sukutis)." For adherents of Kardiya the performance of sikiri is an important part of the funeral rites. See also Ian D. Dicks, An African Worldview: The Muslim Amacinga Yawo of Southern Malawi (Zomba: Kachere Series, 2012), 177-249; Alan Thorold, "Metamorphosis of the Yao Muslims," in Muslim Identity and Social Change in Sub-Saharan Africa, ed. Louis Brenner (Indianapolis: Indiana University, 1993), 79-90.

83 See also Paolo Israel on the changes that the rule of quietness as well as the war movement introduced into the dance and singing cultures of the Makonde in neighboring Cabo Delgado. Israel, "Lingundumbwe."

84 Interview with Lúcia Abdala, Sanga district, February 15, 2013.

85 Interview with Lúcia Abdala, Sanga district, May 30, 2013.

86 These sounds were also talked about as noise (Ciyaawo: maregwe; Portuguese: barulho).

87 Events were located in time through describing the intensity of the war at that moment, which also often involved descriptions of the soundscape.

88 See also Dalila Cabrita Mateus and Álvaro Mateus, Nacionalistas de Moçambique (Alfragide: Texto Editores, 2010), 112-117. According to Mateus and Mateus, FRELIMO's military engagement in Niassa intensified and became "more aggressive" in 1973 and 1974. See also, e.g., Cabrita, Mozambique, 32-33.

89 "Bernardo Moisés Goy-Goy," 223-224. Goy-Goy, who was born in the Lago district of Niassa, served in Niassa throughout the war. From 1966 to 1969, he served in Niassa Oriental. He assumed command of the provincial sub-base. At the same time, he was second in command of the sector of operations. From 1969 to 1973, he served in Niassa Ocidental, and in 1973, he assumed position as chief of military operations in Niassa. Interview with Goy-Goy, Lichinga, August 23, 2013.

90 Following Barry Truax's terminology, "sound signals" are sounds that can be clearly distinguished from the background noise. Moreover, certain sounds stand out as historically important to the community. These "community soundmarks" meaningfully contribute to defining the community and its sense of historical continuity. Truax focuses on the way that positively experienced sounds create a sense of shared community, and he argues that "noise is the chief enemy of the acoustic community." Truax, Acoustic Communication, 66-69. I am, however, also interested in how the ex-combatants' shared memories of a violent soundscape contribute to their sense of belonging to an ex-combatant community.

91 An "acoustic community" is "linked and defined by its sounds." Truax, Acoustic Communication, 66. Raymond Murray Schaffer, The Soundscape: Our Sonic Environment and the Tuning of the World (Rochester, VT: Destiny Books, 1994), 215-217. See also Gernot Böhme, "Acoustic Atmospheres: A Contribution to the Study of Ecological Aesthetics," in Soundscape: The Journal of Acoustic Ecology 1, no. 1 (2000): 14-18. 


\section{Body feelings and violent memories}

The experienced violence of war is mostly not visible as marks on the body surfaces of the DFs I interviewed. Instead, the women expressed internal sensations of discomfort even physical pain. While these strange bodily feelings were found difficult to interpret, many still argued that they were caused by "thinking too much." These negative thoughts, as they evaluated, were provoked by the accumulative effect of present-day worries coming together with their (sensory) memories of the war. Some even spoke of feeling like they are "still in war." In her study of the Mozambican civil war, Carolyn Nordstrom calls for a more nuanced understanding of violence in war. ${ }^{2}$ This involves not only focusing on the violence of killing but also, for instance, the violent removal from one's family and the violence of memories. In this chapter, I will study how the war memories continue to shape the ex-combatant body and its lived relation to the world. I will start by drawing examples from an interview with a DF called Celina. Celina trained in the second group of female recruits from Niassa at FRELIMO's military training camp in Nachingwea, Tanzania. During the war, she worked at FRELIMO's bush hospital at the Central Base of N'sawisi in Niassa Oriental. In the following conversational interview segments, Celina analyzes with Helena how she experiences her aging ex-combatant body.

CELINA: I myself ... because I see the time that I used to work in the war and the running-I ran well with the weapon behind and the bundle behind on my head. But ... I see/experience these days ... even carrying, I am persisting, but these legs are starting to hurt ... the heart is hurting, the heart is hurting [continues in a quiet voice] 'pa-pa-pa-pa.'

HELENA: Like mentally ill.

CELINA: Hmm [affirmation], and this head here hurts, and in these ears it does "bwi-kwi-kwi-kwi-kwi" like someone is blowing into them. Now that there is bothering me. Another time when I'm working a lot that usually starts. When I'm working a lot that there starts. Now these legs seem like ... tied down $[/$ tense/restricted in movement $]$... Aah, even there going up a hill I don't manage. But usually it makes my heart beat. My head, my ears hurt [feeling a sense of pressure] "kweh-kwa-kwa." Yes." 


\section{Violent liberation}

Though Elaine Scarry argues that pain "has no voice" and is in its very nature unshareable, ${ }^{4}$ in conversations between ex-combatants (even in interview contexts), these inner bodily sensations were at least to some degree voiced and intersubjectively shared through onomatopoeic expressions as well as ideophones. ${ }^{5}$ In the previous conversation, Helena, possibly recognizing an echo of her own feelings in Celina's description and emotionally expressive language, ${ }^{6}$ quickly jumps to offer an interpretation to Celina's bodily pain and discomfort. She suggests that it resembles the symptoms of mental illness. Celina nonchalantly affirms Helena's interpretation before she continues to elaborate on the different sensations that take over her body at these moments. ${ }^{7}$ Following her account, I ask whether she thinks that these body feelings are somehow connected to the war. Celina explains further:

I know because as in the beginning I did a lot of work ... when I was a child, when I was a young girl. Now I even say that these things here are the-eeh, they started in the war. Now I am growing/getting older here, and this my body is destroyed/vexed. Yes.

Here, the experience of her aging body is joined with her heavy work experience during the war to give some explanation to the disturbing sensations of her body. Later in the interview, these body feelings become further explained as being provoked (at least partly) by distressing thoughts. In the following extract, Celina explains how she sometimes feels really happy, but then again, the thoughts take over and make her feel ill.

CELINA: These days I live like this well. But . . . as there is no lack of [happy moments]. Eeh, there is no lack. I am living ... I become happy-another time I become happy with those children laughing and laughing, that's it. Another time when those things appear that make me laugh, I laugh. But when those things that make me laugh don't show up another time that's what makes me, iih, become ill. Another time quiet/silent/calm [“juti" is an ideophone that refers to the quiet of sadness]. I don't talk with people. Eeh. HELENA: Seeing people like this not wanting to talk with them?

CELINA: Yes, not wanting! Just staying in complete silence ["nu-nu-nu-nunu-nuh"']. ${ }^{8}$

Words do not just "express feelings" but enact emotion, as Denise Riley argues. ${ }^{9}$ The silence evoked by "nu-nu-nu-nu-nu-nuh" is different from the "silence" associated with communal life. Here, silence involves a withdrawal from the social world and an immersion into one's inner self. ${ }^{10}$ It is a silence beyond one's control, a silence of emotional distress caused by the disturbance felt in one's body. ${ }^{11}$ As Celina explains, when she gets ill, her ancestors' spirits ("acakulungwa wa kala-kala") come to her, and they make her stay still/quiet. The ancestral spirts, as she explains in the final segment, come when she is "thinking too much." 
HELENA: She said do you know why this usually starts that they [the ancestors] come and make you stay seated/still?

CELINA: That there the reason it usually starts, it's usually caused by ...thinking. Another time when I think a lot ... that day they [the ancestors] come.

Celina and Helena both recognize what the ancestors' spirits do as healing, ${ }^{12}$ yet the process is extremely arduous. As Celina describes, during this time, she stops talking; she hardly eats; she does not taste food; she only sits in silence. This silence is a disconnecting silence. As Helena later argues, a person who acts like this appears "crazy" to the rest of the people.

Phenomenologist David Carr writes that though experience is of the present, it cannot be disconnected from the past or from future expectations. ${ }^{13}$ This can help us understand how the liberation struggle is remembered in the women ex-combatants' interview talk and how their current experiences of life both affect and are affected by these past memories. Especially the women's experience of their aging bodies is intimately implicated in this remembering and sense making. Strange body sensations - that indicate a certain malfunctioning of the body-are partly interpreted through the "war experience" but also through the narrative frame of old age. ${ }^{14}$ These interpretations vary between people. One woman argued that her body was only reacting to old age, and the war had nothing to do with what she was experiencing now. Some women linked the feelings of pain and loss of strength in their body to the hard work and poor diet of the war and argued that that work was finally catching up with their aging bodies. Many women, however, spoke of how "thinking too much" provokes bodily sensations (e.g., racing or aching sensations in one's heart, feelings of breathing difficulties, intrusive sounds in one's ears, watering of eyes) that were often also intertwined with emotional responses (sorrow, sadness, melancholia). This points to how physical sensations of the body cannot be separated from emotions or emotions from physical sensations. Some of these symptoms were treated as hypertension by doctors, ${ }^{15}$ yet most of the time, they were not medically diagnosed. Also, the help of traditional healers was not usually sought, and in general, people talked about keeping these feelings to themselves or at least not sharing with non-ex-combatants. ${ }^{16}$ Still, there seemed to be a tacit understanding that these are sensations that other ex-combatants also suffer from. Teresa, for instance, spoke of how she had discussed what she was feeling in her body with some of the male ex-combatants in her village, and they had told her that it was the same for them and that it is caused by the "hard work of the war," but it is also provoked through "remembering," and, they argued, "it won't end." 17 Yet even though the women did not speak of definite cures, they spoke of ways that helped alleviate these sensations and negative emotions. For instance, at the time of my last interview with Celina, she had just received notification that her application for the status of "war veteran" had been approved, and she was entitled to the veteran's benefits. ${ }^{18}$ She expressed feelings of cautious happiness: now she would be on the same line with other ex-combatants, and her present-day worries would lessen. 
Not everyone I interviewed expressed feeling unhappy and ill at ease in their bodies. Some spoke of having gone through tough times in the first years of independence but that these days, they are quite content with their lives. Two women even expressed very strong feelings of happiness. Looking at me with her eyes sparkling, Madiatu Issa in Malulu softly admits being "very happy" ("kurengwa n'nope"). She had very recently received a microloan and was now able to go ahead with her agriculture-based, income-generating project that she was going to work on with her children. She already had some fields, but the loan meant that she could open more fields and expand her production. Another DF, Lúcia, also expressed the happiness of "living well" in her body when Helena asked her about the sentiments of her body these days.

HELENA: NOW these days . . . as you are living . . . how do you feel in your body? Do you feel weak ... or do you feel strong? Are you sad, are you getting . . . nervous ... or not? Or are you usually ... happy? Or not? Or do you usually ... play a lot? Or not? How do you feel in your body about these things?

LÚCIA: These days as I am living in my body here ... these days I am happy ... different from that time. And MY body, even when I go about/move ... I even say to myself, $\underline{\text { ih}}$, I now, $\underline{\text { uuhm}}$, now I'm living well. [small break while we chase a pair of chickens away] These days I am living well, it doesn't compare with that time. But that time I was sad but not a lot. But these days even where I live, sleeping in the night thinking-I DON'T HAVE a lot of thoughts because now I live well. I am taking care of myself. There isn't anyone who says: [continues in high pitch voice] "You, do this thing for me." Because I receive money, and I am taking care of myself and the things that I want. AND MY BODY I feel that I am living well with it. ${ }^{19}$

This is the last interview I conducted with Lúcia in June 2014. The year before I had interviewed her three times. She had been applying for the status of war veteran and the veteran's benefits. At the time, she had spoken wistfully of the future and things that she would do when she got her money. The money signaled not only more material comfort (a better house, for instance) but also more freedom of mobility. She spoke, for instance, of her long-time dream of wanting to leave Macaloge, which she referred to as the mato, and moving to Likole, a bigger village closer to Lichinga. When I met her this time, she expressed being "really very happy" ("ngurengwa roni kwa n'nope"). And though she also spoke of having certain negative sensations in her body that she links to the war experience (possibly caused by the senseless running and the smoke of the ammunition entering her head); she talked of how these days, especially now that she has started receiving her pension, she has more moments in which she is able to forget about the war and push the heavy thoughts away when they try to enter her mind.

These different sensory feelings and emotions, whether positive or negative, intimately mediate the ex-combatants' relationship to the state. Personal 
well-being as well as nationalist sentiment and belonging are negotiated in this affective encounter between ex-combatant body and the Frelimo state. In the ex-combatants' narratives, the memories of the history of contact between ex-combatant and state carry with them-to borrow Slavoj Žižek's words - "a stain of traumatic irrationality and senselessness" 20 that cannot be fully erased but demands continuous negotiation. Even after all these years, the ex-combatant and the state remain closely bound. The state is central in the ex-combatants' struggle for recognition and socioeconomic rights, whereas the legitimacy of Frelimo's claim to state power rests on the nationalist narrative that is written in and through the bodies of ex-combatants. The relationship between ex-combatant, party, and the state is a complicated one. For the ex-combatants in Niassa, the Frelimo party is the only rightful guardian of the state, and the role of ex-combatants is understood as that of holding the Frelimo party in check. The general sentiment is that the ex-combatants would suffer even more if the opposition party Renamo gained control of the state. Multiparty democracy is tolerated, but at the same time, it is understood as bringing unwanted instability and even insecurity. ${ }^{21}$ The ex-combatants' idea of politics is often elitist and exclusionary; they do not appear to consider members of the "civilian population" to be equal members of the political community. Some even spoke of wanting to have separate bairros or villages for ex-combatants to live among themselves. The provincial secretary of ACLLN (also an ex-combatant) claimed to be quoting the words of FRELIMO's first president Eduardo Mondlane when he argued that democracy is "alright" for countries where people have a certain educational level, but for countries like Mozambique, it is a bad idea. His words demonstrate a paternalistic view of politics that is very common among ex-combatants; according to this view, the non-ex-combatant population cannot be trusted to make rational political decisions about the future of Mozambique. They are like children who have not been socialized properly into the political community, and it is the role of ex-combatants to mobilize them to vote for Frelimo.

In Niassa, the relation between the (Frelimo-)state and the ex-combatants is heavily influenced by negative sensations and emotions, which the women (and men) I interviewed sought in different ways to manage. ${ }^{22}$ Some of my interviewees sought to align themselves more closely with the state and thus rewrite their own memory of the war and the nationalist promise of independence and peace in order for it to fit more closely with the actual outcome of independence, a failure to bring an end to social and economic inequality and suffering. Others attempted to draw on another kind of attachment to space and social community outside the whole ex-combatant-state relationship and its violent history, for instance, by identifying themselves more fully through the civilian category of farmer. For others still, the state discourse of remembrance and public recognition of ex-combatants' suffering at official commemoration ceremonies was experienced as helping to reverse some of the personal and collective hurt they feel when remembering their histories as ex-combatants. 
Sara Ahmed argues that "we become alienated-out of line with an affective community-when we do not experience happiness in proximity to objects that are attributed as being good." 23 During the war, "independence" was construed as the object of ultimate happiness and peace for the national community, including the ex-combatants. Yet for many, the experience of independence has been tied to a continued experience of violence. Even though none of the women I interviewed in Niassa spoke of having any thoughts or expectations of economic gain at the time of their recruitment into the army, a large number spoke of promises made during the war (especially by Eduardo Mondlane) about the good life that independence would bring. At the time, these nationalist notions were defined through a socialist discourse of social and economic equality. And though these ideals have long been forgotten in state discourse, the ex-combatants' voices continue to evoke them as they protest the meaning that "liberation/freedom/independence" (the term in Ciyaawo encompassing all these ideas is "wutendele") has acquired through the neoliberal state discourse and economic practices, especially as they themselves have benefited little from these processes. Far from being a historical fact, the meaning of independence is strongly debated in the present. Moreover, "peace" as an embodied experience involves a continuous negotiation over the senses and meanings of past and present experiences of violence.

\section{Notes}

1 The association between "thinking too much" and the concept of mental distress has been explored in other studies in the context of sub-Saharan Africa. See, e.g., Joyce Yaa Avotri, “'Thinking too Much' and 'Worrying too Much': Ghanaian Women's Accounts of Their Health Problems" (PhD diss., McMaster University, 1997); Vikram Patel, Culture and Common Mental Disorders in Sub-Saharan Africa (New York: Psychology Press, 1998); Elialilia S. Okello and Solvig Ekbland, "Lay Concepts of Depression among the Baganda of Uganda: A Pilot Study," Transcultural Psychiatry 43, no. 2 (2006): 287-313.

2 Carolyn Nordstrom, A Different Kind of War Story (Philadelphia: University of Pennsylvania, 1997), 114-132.

3 Interview with Celina Saide, Mavago district, June 4, 2014.

4 Elaine Scarry, The Body in Pain: The Making and Unmaking of the World (Oxford: Oxford University Press, 1985).

5 Elizabeth Dauphinee makes the valid point that the idea of the interiority of pain existing in the disconnected body of the individual is tied to the "Cartesian paradigm of subjectivity." Dauphinée, “The Politics of the Body in Pain: Reading the Ethics of Imagery," Security Dialogue 38 (2007): 139-155. Also, Mark Paterson et al. argue that sensory experiences are always intersubjectively shared. "Introduction: Placing Touch." See also David B. Morris, The Culture of Pain (Berkeley: University of California Press, 1993), 5.

6 Perhaps we can talk of an "acoustic community" also in this sense.

7 Henri Lefebvre and Catherine Régulier make the point that only in distress do we distinguish between these different rhythms that make up our body. Henri Lefebvre and Catherine Régulier, "Attempt at the Rhythmanalysis of Mediterranean Cities," in Rhythmanalysis: Space, Time and Everyday Life, ed. Henri Lefebvre, trans. Stuart Eldon and Gerald Moore (New York: Continuum, [1992] 2004), 88.

8 Conversation with Bernardo Aubi, field notes, 28 May 2016.

9 Denis Riley, The Words of Selves: Identification, Solidarity, Irony (Stanford: Stanford University Press, 2000), 36. 
10 Social withdrawal is commonly seen as a sign of mental illness. See also Arianna Huhn, "Sustenance and Sociability: Foodways in a Mozambican Town" (PhD diss., Boston University, 2013), 185; Arne S. Steinforth, "Whose Madness? Diverging Manifestations of Mental Illness in Dialogue," Curare 32, nos. 1 + 2 (2009): 96-105. Steinforth discusses the Malawian discourses of "madness."

11 Conversation with Bernardo Aubi, field notes, October 24, 2014.

12 For comparison, see Harri Englund, "Death, Trauma and Ritual: Mozambican Refugees in Malawi," Social Science \& Medicine 46, no. 9 (1998): 1165-1174. Englund looks at how Mozambican war refugees in Malawi rely on nonverbal (rather than verbal) methods such as funeral ceremonies and spirit exorcism to cope with traumatic memories.

13 David Carr, Experience and History: Phenomenological Perspectives on the Historical World (Oxford: Oxford University Press, 2014). See also Wendy James and David Mills, "Introduction: From Representation to Action in the Flow of Time," in The Qualities of Time: Anthropological Approaches, eds. James and Mills (Oxford: Berg, 2005), 1-15. James and Mills discuss the "flow of history" as the co-constitutive relationship between past, present, and future.

14 I do not wish to emphasize a "decline discourse" of the aging body but rather I seek to conceptualize its "complex lived experiences." See Linn Sandberg, "Affirmative Old Age-The Ageing Body and Feminist Theories on Difference," International Journal of Ageing \& Later Life 8, no. 1 (2013): 11-40.

15 See also Doug Henry, "Violence and the Body: Somatic Expressions of Trauma and Vulnerability during War," Medical Anthropology Quarterly 20, no. 3 (2006): 379-398.

16 Though this requires more research, the ex-combatants' accounts of having never sought the help of traditional healers appears quite different from the post-civil war context in which, as many researchers have shown, healing rituals were commonly conducted to help individuals and society come to terms and move beyond the violence of war. See, e.g., Victor Igreja, "Gamba Spirits, Gender Relations, and Healing in Post-Civil War Gorongosa, Mozambique," Journal of the Royal Anthropological Institute 14 (2008): 353-371; Victor Igreja, "The Politics of Peace, Justice and Healing in Post-war Mozambique: "Practices of Rupture" by Magamba Aspirits and Healers in Gorongosa," in Peace versus Justice? The Dilemma of Transitional Justice in Africa, eds. Chandra Lekha and Suren Pillay (Scottsville: University of KwaZulu-Natal Press, 2009), 277-300; Alicinda Honwana, Child Soldiers in Africa (Philadelphia: University of Philadelphia, 2006); Nordstrom, A Different Kind of War Story; Paulo Granjo, "Limpeza ritual e reintegração pós-guerra em Moçambique," Análise Social XLII (2007): 123-144; Jessica Schafer, Soldiers at Peace: Veterans and Society after the Civil War in Mozambique (New York: Palgrave Macmillan, 2007), 103-107. Harry G. West argues that the DFs he interviewed in Cabo Delgado in the early 1990s spoke of seeking the help of traditional healers after the war. West, "Girls with Guns," 188. Some ex-combatants that I interviewed spoke of how they "ran to the mosque" after the war ended. This was one way they sought cleansing and forgiveness. As one woman remembered, the chehe assured her that the "war had come from God; it was a great war" and "there was no problem"; she could continue practicing her faith.

17 Interview with Teresa Macotoa, Sanga district, June 7, 2014.

18 Only three of the thirty-four women I interviewed were not receiving their veteran's pension at the time.

19 Interview with Lúcia Ali Abdala, Sanga district, June 9, 2014.

20 Slavoj Žižek, The Sublime Object of Ideology (London: Verso, 1989), 43.

21 Interview with Provincial Secretary of ACLLN Rui Cabinda, Lichinga, June 24, 2014.

22 A version of this passage appeared in Katto, "Emotions in Protest."

The article develops an in-depth analysis of how negative emotions are negotiated in the ex-combatants' accounts and how these negotiations shape the narration of the liberation struggle.

23 Sara Ahmed, "Creating Disturbance: Feminism, Happiness and Affective Differences," in Working with Affect in Feminist Readings: Disturbing Differences, eds. Marianne Liljeström and Susanna Paasonen (London: Routledge, 2010), 34. 
$\because$ Taylor \& Francis Taylor \& Francis Group http://taylorandfrancis.com 


\section{Part III}

\section{Beautiful belonging}

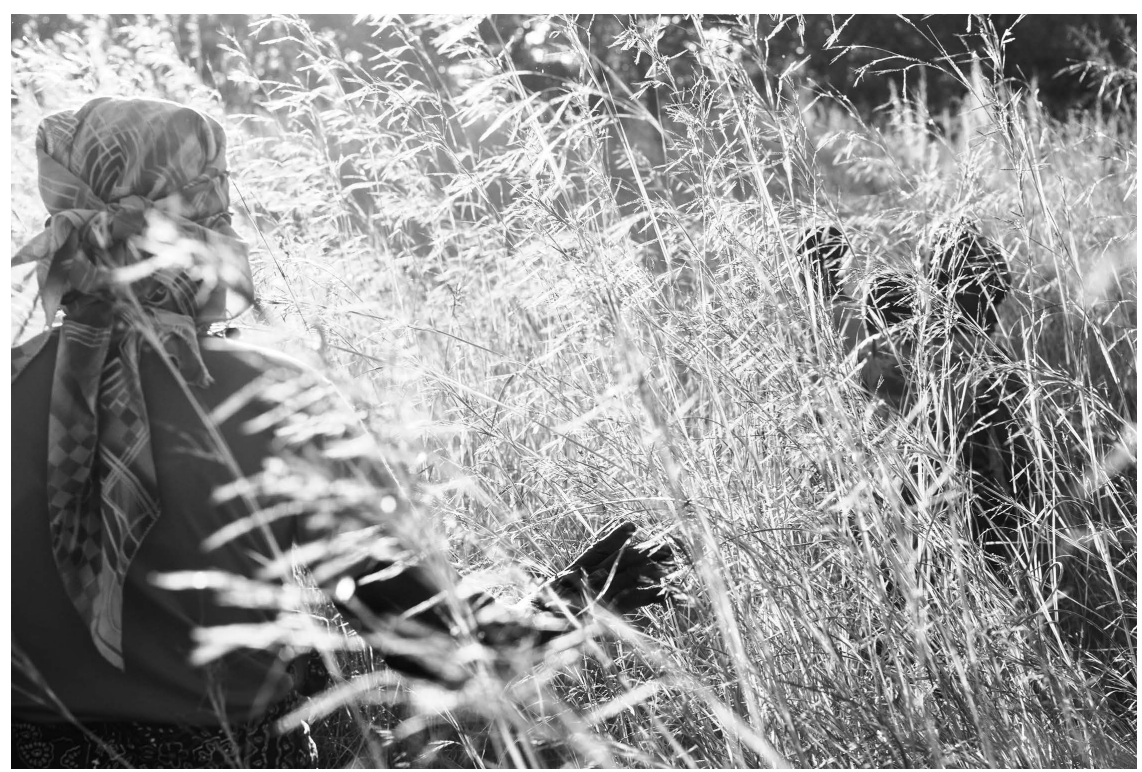

Figure I. 1 Rice harvest time in Macaloge 2013

It is rice harvest time in Macaloge. Helena is walking ahead of me in the soft, late afternoon sun as we follow our guides - three local kids-along the winding path to Rosa's field. We have sent word to her the previous day, but when we arrive at her place, she is not there. The kids we find running around inside her yard tell us she is still working in her field, but the field is close by, and they can take us there if we wish. "Very close" turns out to be a relative measure, as the three youngsters lead us along an almost hidden path, overgrown by vegetation, for the good part of an hour. When we reach Rosa, she is done for the day, just tying her bundles with three young helpers, ready to head home again. The radio is blasting with music. In good humor and animated by our visit, Rosa proudly demonstrates the produce of her day of hard work: one bucket and 
several smaller sacks filled with rice. Then bundles of different sizes are balanced on bigger and smaller heads, and our little caravan heads back home, following the same winding path past small fields and through yellow grassland. Tomorrow, they will return, and every day after, until all the rice is harvested. In these days of peacetime, these are the mundane movement patterns closely guided by the seasonal rhythms of the machamba that govern the DFs' body-landscape relationship. Though tough, even backbreaking, this engagement is very different from their remembered wartime movement.

In this study, landscape is not understood as something we can distance ourselves from; rather, we are bodily embedded within it. By moving through it, it shapes our bodies, but at the same time, we also contribute to its making. In Part III, I shift my analytical focus to what following Merleau-Ponty's phenomenology can be called the "in-betweenness" of body and world. My starting point is that the landscape (the object) does not exist in a dualistic relation to the subject; object and subject are intertwined. This is what is often referred to as embodied landscape. ${ }^{2}$ As already touched upon in the previous chapters, the body-landscape relationship is a reciprocal relationship in which each is being made in relation to the other. The question is not merely about our relationship with the environment but also about the relationship that the environment has with us and how it interacts with our bodies.

In Part III, I will mainly work with the concepts of "aesthetics" and "rhythm," which I suggest help us to analyze the ex-combatants' body-landscape relationships. Here, the concept of "aesthetics" derives from the environmental aesthetics theory of American philosopher Arnold Berleant. He draws on an older meaning of aesthetics that denotes sense perception. ${ }^{3}$ Aesthetic engagement, as Berleant argues, involves our whole body and all our senses in the active perception of the environment. He writes, "When aesthetic engagement is most intense and complete, it achieves that fulfilment of value we call beauty." 4 Berleant thus radically reconceptualizes "beauty" as a relational notion, not tied to either object or subject. Henri Lefebvre's notion of "rhythm," moreover, further contributes to the conceptualization of the ex-combatants' desired bodylandscape relationships. Through "rhythm" we gain closer analytical insight into the historical processes by which people come to value certain landscapes as beautiful and others as ugly and how this contributes to their sense of attachment and belonging. Rhythm is a wholly spatiotemporal concept: ${ }^{5}$ As Lefebvre eloquently writes, "Everywhere where there is interaction between a place, a time and an expenditure of energy, there is rhythm." ${ }^{.6}$ Lefebvre suggests that by studying rhythms, we can begin to understand the history of space. ${ }^{7}$ This study of rhythms he calls rhythmanalysis. Importantly, a rhythmanalysis does not aim to "isolate" or to stabilize the dynamic relations that exist between body and landscape. As he argues, rhythmanalysis starts from identifying the different rhythms involved. Rhythmanalysis, as Lefebvre describes, "seeks to grasp a moving but determinate complexity (determination not entailing determinism)." As he insists, and I fully agree, the analytical process should be no less complex 
than the complex "reality" being studied, in this case, the plurality and intricacy of human relations with landscape.

Lefebvre's "rhythm" builds on his earlier work on the production of social space. However, his rhythmanalysis puts the body more directly at the center of analysis. As he argues, the body is the constant reference: "the measure of rhythms.", I already touched on the body as an assemblage of rhythms in Part II. I looked at how the violent memories of war affect the body, causing sensations of arrhythmia, and how these disturbances are managed. In Chapter 5, "Living Landscape," by examining the life narratives of one female ex-combatant, I explore her historical relationship with the different lived landscapes of her life trajectory and study how she negotiates her bodily relationship to them. Here, following Lefebvre, the life course is conceptualized as an individual rhythm or what I call a life rhythm.

Seeking to further understand what constitutes a desirable body-landscape relationship, in Chapter 6, "Rhythmic Beauty," my analytical focus turns to the meanings of the "beautiful/good" in the DFs' landscape experiences. Drawing on Arnold Berleant's environmental aesthetics theory, I show how a landscape is judged "beautiful" based on the "lifestyle" (that is, the sensory quality of body-landscape interaction) that the landscape is imagined to enable. Here, imagination does not imply fanciful disembodied thought but rather a bodily anticipation based on the awareness of one's history of previous contacts. Moreover, as this chapter argues, aesthetic sensibility is deeply intertwined with our experience of socio-spatial attachment/detachment. In the DFs' narratives, the "bush" is often described as the opposite of a beautiful place. Still, I suggest that the notion of the beautiful landscape cannot be understood without understanding the aesthetics of the bush. Moreover, to understand the beautiful, we must explore the interplay between (or the intertwining of) the ugly/displeasing and the beautiful in the DFs' aesthetic experiences of their homeplaces. As I show, in the DFs' narratives, the aesthetics of the "bush" and the aesthetics of home continue to be negotiated in relation to each other. Finally-engaging with Henri Lefebvre's rhythmanalysis - the chapter explores how personal belonging in the DFs narratives is always negotiated in relation to other individual and collective rhythms, which together constitute the polyrhythmic landscape of "Mozambique." As my analysis shows, the national landscape is not a homogenous, unified landscape; rather, it is perceived as consisting of multiple and unequal landscapes that are valued according to different scales of beauty.

In Chapter 7, "Home, (be)longing, and the Beautiful," developing these ideas further, I move to reconceptualize "belonging" as a relational notion. As I suggest, "belonging" is not a subjective experience but is shaped and negotiated in a reciprocal relationship between body and world. My analysis shows how aesthetic sensibilities influence how belonging is negotiated at different scales: body, family, neighborhood, town, province, nation, and even the globe. In the DFs' narratives, belonging stands out as a negotiation for a relationship of peaceful dwelling with the landscape. As the body is intimately engaged in a lived relationship with the world, this sense of peaceful dwelling requires simultaneous 
negotiations at different scales. These negotiations have unequal results that contribute to different intensities of belonging. As the DFs' narratives show, belonging is often not experienced as a completely fulfilled relationship on all scales.

\section{Notes}

1 See Guðbjörg Rannveig Jóhannesdóttir, "Landscape and Aesthetic Values: Not Only in the Eye of the Beholder," in Conversations with Landscape, eds. Karl Benediktsson and Katrín Anna Lund (Burlington, VT: Ashgate Publishing, 2010), 109-124. She argues that Merleau-Ponty's concept of "flesh" apprehends this in-betweenness.

2 For example, Davies, (In)scribing; Bender et al., eds., Stone Worlds; Ingold, “Temporality of the Landscape."

3 More recent studies on aesthetics in Africa have looked at aesthetics as sensory engagement. See, e.g., Achille Mbembe, "Variations on the Beautiful in the Congolese World of Sounds," in Beautiful - Ugly: African and Diaspora Aesthetics, ed. Sarah Nuttall (Durham: Duke University Press, 2006), 60-93; Sarah Nuttall, "Introduction: Rethinking Beauty," in Beautiful - Ugly: African and Diaspora Aesthetics, ed. Sarah Nuttall (Durham: Duke University Press, 2006), 6-29. See also Wilfried Van Damme, Beauty in Context: Towards an Anthropological Approach to Aesthetics (Köln: Brill, 1996).

4 Arnold Berleant, Living in the Landscape: Toward an Aesthetics of Environment (Kansas: University Press of Kansas, 1997), 110.

5 Lefebvre and Régulier, "Rhythmanalysis of Mediterranean Cities," 89.

6 Lefebvre, Rhythmanalysis, 15.

7 Lefebvre, Production of Space, 117.

8 Lefebvre, Rhythmanalysis, 12.

9 Ibid., 20. 


\section{Living landscape}

In this chapter, I look at how the personal and "experiential meaning"1 of landscape evolves through the individual life course and is furthermore shaped by the changing relationality between body and environment. Following Lefebvre, the life course can be conceptualized as an individual rhythm or what I call a life rhythm. Body and landscape are continuously shaped in relation to each other throughout the length of one's life. Seen from the perspective of the individual, the life course is linear and singular; a human life has a beginning and an end. From the perspective of the social group, its rhythm is cyclical. As Carole S. Vance befittingly writes, "Personal life as lived and experienced is not totally private and individual" but culturally shaped. ${ }^{2}$ The shape of a life and the meanings attached to the various life events (e.g., its peaks and declines) are culture bound. For instance, the physical changes linked to the body's transformation from infancy to adulthood are interpreted according to cultural scripts. There is always a high level of continuity in these meaning making processes. Still as Lefebvre argues, there is "no identical absolute repetition," but repetition always produces differences. ${ }^{3}$ It is in this repetition that the transformative energy of rhythm lies. In this chapter, I look at how personal life narratives allow us crucial entry points into understanding wider cultural histories of body-landscape relations and especially changes in those relations.

I focus on Helena's narratives here as she is such an integral part of the texture of my research material. Helena told me stories about her life in many different situations over the months we worked together. Some stories she told in interview situations. But she also liked to weave her stories into other people's interviews. Many of her stories were told on the move as we navigated our way around Lichinga and the rural villages of northern Niassa. Other stories she told as we prepared food and ate or otherwise sat together passing time in the evenings before going to sleep at the local guesthouses in the districts. Helena expressed a deep concern for the continued remembering of the history of the liberation struggle. She also proudly identified herself as a person with a lot of memory in her head. She told me that when people from Maputo came with questions about the liberation struggle or they wanted to identify and map out the locations of certain wartime events, she was called to come and assist. Helena took the work that we were doing very seriously; she was especially 
thrilled that someone was finally interested in writing about the Destacamento Feminino of Niassa. Yet more than that, she wanted her own story woven as part of that bigger narrative. In this chapter, I do not isolate Helena's landscape memories, but I look at them in relation to those of her generation of female and male ex-combatants. Beyond that, I explore what these life narratives can tell us of the relationship of this specific group to the wider physical and social world that encompasses them and of the ways that the ex-combatants negotiate their socio-spatial belonging. The historical "truth" of life memories, as Heidi Gengenbach convincingly argues, lies exactly in their social embeddedness. ${ }^{4}$ This chapter is divided into five subchapters (as you read, see Maps 6.1a and $6.1 \mathrm{~b}$ on page 183 for support in spatial orientation). I start by examining the shape and meanings that the prewar childhood landscape assumes in Helena's memories. Then I move to look at how this body-landscape relationship is disrupted and transformed by the war and, moreover, how body and homeplace becomes politicized and militarized. In the third subchapter, I explore the relationship between the female combatant body and the army, looking at the ways that Helena and the other DFs navigated their sexual lives in the military camps. In the fourth subchapter, I look at Helena's military engagement and how motherhood shaped the soldier's body and movement and, conversely, how soldiering shaped motherhood. Finally, I examine the new set of rhythms that peacetime introduced and how Helena and the other DFs continue to negotiate their own bodily space and adjust their life rhythm to the changing social times.

\section{Childhood places and colonial landscapes}

HELENA: The life of Chiconono ... there ... every village lived separately, right? Every chief takes his people and brings them together in one village. So they stay there. THERE WHERE the chief is ... no one could enter in whatever way-you were prisoned. The person that asked, "I want to see the chief" ... was just shown the finger. [smiles as she speaks] That's your photo-you already saw the chief. There was no entering into his courtyard to see, no way. HE FORBAD. Now, I, as that chief was my grandfather-

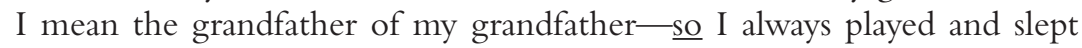
there. I would take friends: "Let's go play." BUT HE WOULD GET

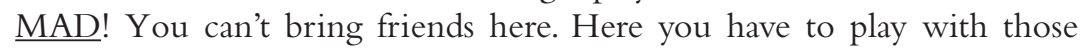
that are here. I was stubborn! I would always take friends, uuh, but how ... what type of house is this that a person from outside can't enter? What did grandfather save/keep here?

JONNA: Hehehe.

HELENA: [Speaks with laughter in her voice] I DIDN'T KNOW THAT he was their CHIEF ... of the chiefs. I DIDN'T KNOW!

JONNA: Hehe.

HELENA: But after ... the war I got to know when they explained: "You used to play like this, it was that." I: "Really? I didn't know!" As it was before growing up, I didn't know. ${ }^{5}$ 
Certain childhood places stand out with more narrative intensity in Helena's stories. The house of her maternal grandparents emerges as the focal point of her childhood lifeworld that anchors her movements. Helena was especially close with her grandmother as a child. Her grandmother was the one who looked after the grandchildren (or, as Helena says, "controlled them") and prepared food for them. She came to fetch them when it was time to eat or take a bath, and at night, they would sleep in her house. As Helena affectionately accounts, "We [the grandchildren] said, 'The eldest here is our grandmother. She is the elder in charge, our boss." "Helena proudly speaks of even inheriting her unyago name ("Helena") from her. As was often customary (especially with the first grandchild), her grandmother took Helena to live with her as soon as she was born, and Helena grew up believing her to be her mother. She describes living a normal childhood, even though her grandparents' home was no ordinary homestead. Her grandfather was "the chief of the chiefs," an important regional chief in the area of Chiconono, Niassa. According to oral history, the mythical home of the Ayaawo is located in Chiconono. These days Chiconono encompasses the localities of Chiuanjota and Ligogolo (see Map 6.1a on page 183). The house of the chief was built by his subjects; one village would come one day to build one part, another village another day, until the house grew big. But as Helena narrates, she was largely unaware of her family histories and privileges at the time. Instead, she remembers being surprised to discover that their home was not open for outsiders. In her narratives, Helena often emphasizes her own agency and control over her life path and bodily space. Even here in this story, confronted by these regulations imposed upon her mobility by her grandfather, Helena emphasizes her rebellious attitude. She speaks of how she goes against her grandfather's orders and questions the idea of her home as a closed space that her friends cannot enter. She describes her behavior as "stubborn," which is a quality she regularly attributes to her younger immature self. The war started when she was only about eight years old. "I was too young to understand/know," she often emphasizes in her stories. Her own personal memories of that time and place are scarce, and what she remembers has been complemented by the stories and memories of others after the war. ${ }^{7}$ In the following excerpt Helena pursues to talk about her memories of Chiconono:

The memory that I have of it in my head ... Only when I arrive there ... I usually ask: "Give me- . . show me where are those pine trees . . that when he arrived, that white patron of that shop- $\underline{\text { here, }}$, there used to be a shop, here-that SHOP, that patron of that shop ... planted THREE pine trees here-where are they?" They say they ARE THERE where the grave of your grandfather is. Hmm. Hmm. In my memory ... ONLY that there stayed, only! Hmm. .. . [continues to talk in a low voice] To know/ recognize ... that place. Only. ... As we left in a chaotic/disorganized way ... in the time of the war ... the people don't leave well, they leave FLEEING, running . . not managing to do many things. Hmm . . . hm. 
There, $\underline{\text { ah }}$... . at that time it was called ... Vila ... Monte Alegre. It is this Chiconono. Hmm. So, MAVAGO ... is Tenente Valadim ... in Mavago. To there it is a long way! It is by the border of Tanzania . . . there. So, Cuamba ... Nova Freixo ... that time. Here in Lichinga it used to be Vila Cabral. It is here, the city of Lichinga. ${ }^{8}$

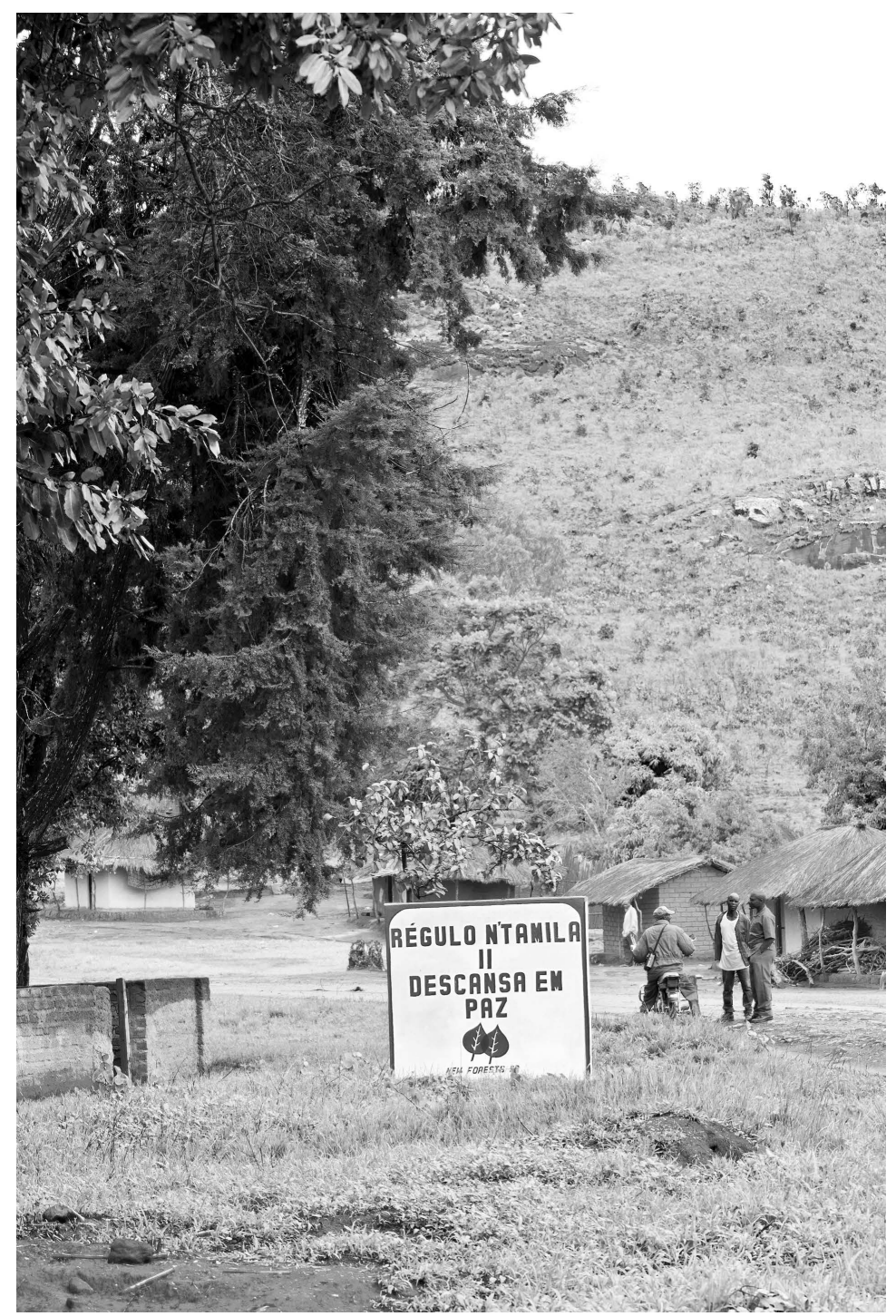

Figure 5.1 Tomb of Ce-N'tamila II, Chiuanjota, Muembe, 2012 
According to the oral tradition of the area, the first Ce-N'tamila was the uncle of Ce-Nyambi, later known as Ce-Mataka I. Ce-N'tamila was a powerful but gentle leader. As the story goes, the nephew surpassed the uncle through ruthless military ambition. Ce-Mataka I proceeded to establish a powerful, centralized Yaawo state in the mid-nineteenth century.

(Interview with Ce-N'tamila [N'tamila Saye] and Ce-Doas [Ndala Yinusa], Chiuanjota, Muembe district, June 11, 2013.)

It is these pine trees (see previous picture) that stand out in Helena's own memories of her childhood place. They are closely linked to a Portuguese shop that was established in Chiuanjota a short time before the war. Helena remembers how she had just returned from unyago at the time. Over the course of the months we spent together, Helena told many stories of her visits to this shop. Sometimes she went alone, sometimes with her mother. As she fondly remembers,

I had a small basket that my father bought me . . . that didn't quite carry five kilos. That basket suffered! Today carrying other type of produce ... IF TODAY IT IS MAIZE . . . tomorrow it is beans . . . after tomorrow: potatoes!

She also speaks of how she thought that the money she received for the farm produce was a lot since she was able to buy so many different things: salt, soap, capulanas, and sugar. Sugar, especially, was her favorite. These days, the pine trees that in Helena's memories are linked to the Portuguese shop mark the gravesite of her (mother's) grandfather Ce-N'tamila II, who died already before the war. When a chief dies, as I was told, he is buried in his house, and his people move to another location. When Ce-N'tamila II died, the village moved a couple of kilometers to the east to a place that the people named Ngalinje, which as Helena explains, means to go and experiment, to go and try if it is a good place in which to live. ${ }^{9}$ Ngalinje is the place where Helena was living when the war started, but the place where her grandfather's tomb now stands is the place where she was born. The memorial stone erected there in recent years by one of the forest companies (New Forests) operating in the area pays respect to the memory of this great chief. For Helena, it serves as a reminder of her personal historical connection to the place. She has fond memories of her childhood homeplace and remembers living a good life there. As she describes, it was a place "full of mountains ... full of rivers ... cold ... in the center. But we, as we didn't know — we hadn't been to other places yet-we said that, here, we are living well!"10 It was a "beautiful place" ("um lugar bonito"), she further argues, since it was the place where the big chief lived, and it was "full of people." The 


\section{Beautiful belonging}

village was much bigger then than it is these days. It extended from Ligogolo to what is now known as Chiuanjota. At the time that the war started, the political center of the village was in Ku-Ngalinje.

The shape of Helena's childhood landscape and her relation to its various places is continuously remade through the present. ${ }^{11}$ The previous interview excerpt shows, for instance, how the landscape was reordered after the war. New names redefined old places and integrated them into a new spatiotemporal construct: the People's Republic of Mozambique. Most of the towns that Helena names (e.g., Vila Cabral, Nova Fresh, and Tenente Valadim), though located in Niassa, were unknown to the DFs before the war. Hardly anyone knew the name "Lourenço Marques" (now Maputo). In the lived geographies of the majority of the northerners, Lourenço Marques did not feature as a meaningful locale. The capital city was not known to offer any significant work opportunities for the people from the far hinterlands of the north. Some people knew Lourenço Marques as the location of the dreaded Machava prison, where political prisoners were sent. I was told that people commonly referred to Lourenço Marques as "down below" ("kwi-wanda"). ${ }^{12}$ When someone traveled to Lourenço Marques (or the southern region of Mozambique in general), as Maria Ajaba told, people would say "apite kwi-wanda, kwi-wanda kwa kutadika" ("the person went down below, down below far away"). ${ }^{13}$ Especially for those of their female age group, these places did not exist within their "horizon of reach." ${ }^{14}$ Next, Helena beautifully analyzes her sense of locatedness and understanding of the moving geography of her home space before and after the war:

HELENA: I-about Mozambique . . . I can't lie. It didn't exist this name of Mozambique. No one knew. Despite being very young ... but this name we never heard. ... We only lived. Every person saying that "새, I, my country is right here-REFERRING TO WHERE THEY WERE! My country is right here." There Chiconono, to where I was referring, is from Muembe. Because Muembe-That my oldest uncle ... he arrived a long time ago ... there ... with other family. ... So where I was referring ... we that are here, in our homeland ... it is from Muembe ... to here in Chiconono. Because there in Muembe in the past it wasn't Muembe ... it used to be Luwila.

JONNA: Luwila?

HELENA: Luwila. Yes. That river when you leave from the administrative center of Muembe ... when you go to Chiconono, isn't it? That river that we cross ... is Luwila. THAT NAME of Muembe I started to hear when I returned from the mato ... after the war. ${ }^{15}$

João Facitela Pelembe, a political commissar in the liberation struggle, in his biography writes of the novelty of the idea of Mozambique for many people during the war, especially its geographical vastness, to say, its "extension from Rovuma to Maputo." ${ }^{16}$ He writes how some people at the time "thought that the identity of everyone started and terminated where they found themselves." This 
resonates closely with Helena's narrative of her sense of belonging before the war. Many of the other DFs I interviewed also spoke of similar experiences, and like Helena, they often argued that it was because they were "very young." The male ex-combatants that I interviewed spoke of slightly different lived landscapes before the war. At this time, many of them were already experienced in traveling to neighboring countries. Being older than the female recruits, they also spoke of having some understanding of the idea of "Mozambique" when the war started. An elderly male ex-combatant, Mwemedi N'tawula, remembers that he heard the name Mozambique for the first time during a population census before the war. The colonial state officials, as he recalls, were the ones to inform him and his wife that the land upon which they stood was called Mozambique. Yet at the time, these words did not resonate with his own sense of spatial location and belonging. As he narrated, "These whites here, where they put us, they say it is Mozambique. But we the owners/inhabitants considered that all of this territory belongs to Ce-Mataka!" ${ }^{17}$ His account strongly brings forth the dissonance between the spatial discourse of the colonial state and the local people's sense of place identity. Prior to colonial conquest of the area (see also "Historical Landscapes of 'Niassa'”), bigger chiefdoms (like Ce-Mataka's) had been founded on the political alliances between a number of matrilineages on a given territory. People's personal relationship to land was largely defined through their family and especially their matrilineal kinship group. Living arrangements after marriage were usually matrilocal. A man would move to live with his wife's family. In the beginning, he had to work in their fields, thus proving to the girl's family that he was a good worker. Later, if he had several wives, he would divide his time and labor between the homes of his wives. Helena, for instance, told of how her paternal grandfather had come from Cóbué on the northern shore of Lake Niassa to sell fish in Chiconono. He met a girl, got married, and settled in the area of Chiconono. Her maternal grandfather left Majune and followed his father to Chiconono and married there. Movements like these were very common at the time. Otherwise, people lived in small family groups that practiced shifting agriculture; they would relocate once soil became exhausted in one place. Helena describes the geography of her childhood homeplace expanding from her home village in Chiconono to where her mother's brother lived in Muembe (known as Luwila at the time); traveling along the main road this distance measures about $20 \mathrm{~km}$.

The landscape of her childhood though grounded in the immediate surroundings of her daily activities, of playing, visiting family, helping grandparents in the machamba, and, for instance, going to the shop-also reached beyond those boundaries through the travel stories of her father and other male relatives. Anne Buttimer writes that home and reach exist in a reciprocal relationship. ${ }^{18}$ The experiential meaning of homeplace is constantly reshaped in social and spatial interaction. Moreover, as Yi-Fu Tuan argues, the scales of homeplace change and often broaden throughout an individual's life course. ${ }^{19}$ In order to understand the different processes that constitute place identity for an individual or a group, Buttimer suggests that we analyze the reciprocity of 
home and reach on three different levels: the level of ideas, social networks, and the physical "homegrounds." Of course, in reality, these levels are intertwined. For the DFs before the war, even though their physical homegrounds did not reach very far (as Helena's narrative shows), their geographical imagination was broadened, for instance, by the travel stories of people in their family circle. Helena's father, always concerned for the well-being of his family, as she described, "didn't like to stay at home up to two months. He had to go to Malawi, South Africa, Quelimane, Tanzania. He didn't like his children to use dirty clothes." Taxation was high in Mozambique, and few opportunities existed for making money. Yaawo men, like Helena's dad, seasonally migrated to neighboring countries, where more favorable economic circumstances prevailed, to earn money to pay their taxes and buy household goods, such as pots and pans, capulanas, and, occasionally, bicycles to bring back to their wives and children. Though women hardly participated in these migratory labor movements, they heard tales of these journeys from their male family members. Helena speaks of the tough work that her father did in the Rand mines in South Africa. ${ }^{20}$ She remembers her father telling her how they went down into a hole with an elevator. As he described, there at the bottom, it was like "a city with light and everything," and there they would dig for "rocks of gold." It was tough work. As her father explained, a person was not allowed to stay in the mines for a long time, and when they were sent home, they could not return the same year. The mines had a reputation of being deadly places. Galli claims that the oral narratives she recorded in Unango, in the district of Sanga in the late '90s, suggest that many of those who registered for one-year contracts died and never returned home to Niassa. ${ }^{21}$

Apart from working in the mines in South Africa, Helena's father also worked in Tanganyika. The narratives Helena tells of her father's time in Tanganyika, working on the cashew machambas, demonstrates the different economic rhythms of Mozambique and Tanzania and how they were experienced by the migrant workers. For instance, Tanzania at the time had a higher level of industrialization, better transport systems that enhanced the mobility of people and shortened the distances between places. There were significant differences between the colonial powers in their policies of economic development, which also effected the social change of these countries. Mozambique remained relatively underdeveloped economically, especially in the north. Still, the people of northern Mozambique did not live in isolation but were deeply immersed in complex patterns of interaction and exchange within the region. It was through labor migrants that new nationalist notions of spatial belonging first started spreading to northern Mozambique in the late 1950s. ${ }^{22}$ It was upon this basis (and the experience of the repressive colonial policies) that the liberation struggle commenced. In the case of the younger generation coming of age at the time, as I show in the following subchapter, it was, moreover, FRELIMO's political education on the geography and history of "Mozambique" that significantly expanded their geographical imagination and transformed their horizons of reach. 


\section{Militarization of homescape}

Because WE ... when we left home ... we went to the mato. That time was before
we had grown up. Because ... INTO OUR military life ... grown-up people didn't
enter. They sought young girls so they would not to have those ... thoughts about
parents—not to remember home! You only have to think about what you are
doing! Hmm? So we went before we had grown up. ${ }^{23}$

When FRELIMO started spreading its military activities in Niassa in 1965, the colonial state responded with extreme measures to restrict the contact that the civilian population had with the guerrillas. In the area of Chiconono, the colonial troops destroyed villages and forcefully moved people by trucks to a fortified village (aldeamento; locally known as "waya") constructed in Ligogolo, the administrative post of Chiconono. ${ }^{24}$ This settlement was fenced off with barbed wire and patrolled by the soldiers. The people were not allowed to build huts out of clay bricks, only grass ("capim"), so that the soldiers could better see and thus control the population. The movement of people was strictly regulated, and people had to attain pass slips when they wanted to tend their fields, collect firewood, and fetch water. But even despite these defensive measures, FRELIMO managed to establish contact with villagers as they moved outside the aldeamentos. This way, the guerrillas were able to organize several breakouts from the camp and assist people to escape to the bush. Helena's family had also been forced into the camp. Helena remembered how she did not manage to flee with her mother when the FRELIMO soldiers came for them because she was playing on the other side of the village. But the soldiers returned for her, and she was later reunited with her mother in the bush. The journey to the base has stuck in Helena's memory as very strenuous. As she narrates,

It was far. It was ... it was forty-eight kilometers. And we walked at night! There from the arame farpado [barbed wire] we left at night, at night. There were also rivers. We crossed mountains also. So there . . very far there at the end. So we stayed there. ${ }^{25}$

N'nowi was the name of the military camp. Here, Helena lived with her parents among the civilian population in the proximity of the soldiers' camp. This was the beginning of the war; the bombings were intense, and the people were terrified of the planes. In a short time, the war completely transformed the daily routines of the population. As Helena describes, during the day, they hid in the bush under the trees and returned to their huts only when it got dark in the evening. Then they lit their fires. Early in the morning before sunrise, they again returned to the bush. Helena remembers living like this with her family for several months, even up to a year, before she was recruited to join the guerrillas in late 1966.

Helena speaks of being so young at the time that she did not understand what the war meant, and she had no idea that bombs killed. Many of the DFs 
I interviewed spoke of how they grew up in the military during the war. Usually, the female recruits were in their early teens, but I interviewed a few DFs who were as young as Helena when they joined the guerrillas. As most parents at the time did not keep track of the ages of their children, Helena does not quite know how old she was at the time that she was recruited. According to her own evaluation, she was between eight and thirteen years old. Her experience was that she was a small girl who had not yet grown up. The soldiers also did not always know who was old enough for military training. I was told that to determine the age of a child, the soldiers would sometimes ask the children to reach with their arm over their head to touch their ear with their fingers. Those who were able to do this were sent for military training, while the others were sent to FRELIMO's school in Tunduru. ${ }^{26}$ Lúcia Bala spoke of how she was first mistaken for being younger than she was, and she was sent to Tunduru. Laughingly, she tells me that the soldiers soon discovered that she was "already grown-up, just short." She was then sent to Nachingwea to join the others in training. Some of the younger DFs I interviewed told of how they had first studied in Tunduru before joining the army. The guerrillas also tricked many families by saying that their children would go to school, but instead, they were trained as soldiers. Helena spoke bitterly of the fact that she was not given the opportunity to study. She was recruited into military training, even against her parents will. Helena's dad had already left for training to Nachingwea, but Helena's mom resisted the idea of her recruitment very strongly. Helena spoke of how her grandmother was the one who convinced her to go, saying that if she did not, the whole family would suffer. According to Helena, one of her aunts had been killed by the guerrillas for refusing to go. FRELIMO held ultimate authority in these areas, and people were afraid to disobey their orders. Helena also speaks of how another aunt of hers, Teresa Amudi, the commanding officer of the DF in Niassa Oriental, played an important role in mobilizing her to join the guerrillas. Still, as Helena emphasizes, ultimately, she was following the orders of her grandmother when she left.

As many ex-combatants narrated, voluntary recruitment through political mobilization was more common in the very beginning of the war, but soon forced recruitment became the norm. ${ }^{27}$ Fátima Aquili (the commander of DF in Katur) explained that mobilization was very difficult, because the mothers were prohibiting the girls from joining for the fear that they would "die in the bush." As she says, it became necessary for us to use "the method of just taking [método de que só apanhar]. Now it was obligatory." 28 Coming across girls in the machambas or on the trails, the soldiers would capture them. As Fátima explained, the guerrillas made the decision to start forceful recruitment because they did not have enough people and especially not enough DFs. When the girls were brought to the base, the political mobilization commenced, and they were explained why they had been taken. "You won't be killed," they were told, as Fátima narrates. "We only took you here so that together we will liberate our country! We are oppressed." According to Fátima, many ran away, but "those that understood, they stayed until the end of the war." In many of the interview 
accounts, the forced removal from one's family was narrated as one of the most troubling memories of war that several DFs found difficult to frame meaningfully. Rosa Namate, for instance, at the end of her last interview when I asked if she wanted to add something, spoke of not understanding the violent manner of her recruitment and the way she was taken from her family. She expressed this as her most painful memory from the war. Being so young at the time, she was first taken to Tunduru to study before she was sent for military training in Nachingwea. And she spoke of trying to escape from the soldiers as they were taking her to Tanzania. At one point, she refused to walk, forcing the soldiers to drag her along. All the way, she kept hoping for the soldiers to take pity on her and leave her behind. The trip to Tanzania was a very significant event also for Helena, though she did not express being traumatized by it in the same way as Rosa.

When Helena was recruited, she first stayed at the military bases for a few months before she was sent to Nachingwea. Helena says that during this time, she got accustomed to the soldiers and her "fear already ended." At the Central Base of N'tiringwe, the soldiers immediately started giving some rudimentary training to the young recruits (boys and girls) so that they would at least know how to defend themselves if the base was attacked. Helena did not talk much about these first months at the base; instead, her stories focused on her travel from the base to Nachingwea. She had two stories that she repeated several times. The narrative shape of these stories was never exactly the same, but although the twists and turns of the plot were always slightly modified, the moral message persisted. In the first narrative, Helena tells of how her mom persistently followed the guerrillas when they were taking the new recruits for training in Tanzania, trying to talk them into leaving her daughter behind. As Helena narrates,

When they were taking me, my mother was crying. Even on the day that I was LEAVING to Nachingwea, my mom was also following behind . . . pursuing. "I also have to go there." He said: "No, you mama have a child on your lap ... another one is this here who is still small, another is there who is still small. We want your daughter to teach her. TOMORROW she will be well. Mama will be content." She said: "No, you [soldiers] will kill my daughter. Like this also when her father hears, how is it going to be? ... Because her father also is there in Nachingwea." He said: "Well that's good. She will live with the father." .. U Up to ... almost two days, my mother pursued ... to see if he would send me back. So he threatened saying, "You, mama, if you PURSUE ... we will tie you up and leave you there by the tree." My mother then [Helena continues in a lower voice] that's it, she returned. She returned home. And I went to Nachingwea and I met with my father. My father got angry. ${ }^{29}$

It is notable that Helena does not speak about her own feelings, only those of her mother. In other versions, she emphasizes her own agency in deciding to go with the guerrillas. The second story Helena tells is about meeting her father 
and her father trying to get the guerrillas to let his daughter go. Sometimes she speaks of crossing paths with her father in the bush on the way to Nachingwea and other times meeting him in Nachingwea. Next, she tells of how they met in the bush:

My father was ... a soldier. ... He also trained in Nachingwea. ... When they were returning ... we crossed paths as I was going to Nachingwea. My father started to ARGUE with the officers. "How is it that you managed to get my daughter also to go to WAR? So either I leave my weapon, my daughter takes the weapon, and I will stay at home." The elders then started to counsel, and he accepted. I continued to Nachingwea, I also trained ... I returned. ONLY that ... we lived in different bases. My father lived at another base, I lived at another base. We couldn't stay at the same base because ... IT COULD ... CAUSE affiliation [preferential treatment/ favoritism], isn't it? It could lead-One could become undisciplined. So they separated the bases. I grew up right there. I went when I was thirteen years old. ${ }^{30}$

All the versions of this story convey the anger of Helena's father and tell of his verbal threat of deserting the army if the guerrillas did not let his daughter go. Also, often when telling the story, Helena gives herself a decisive role in convincing her father to continue in military life and to let her also become a soldier. The moral of the story can be found in the following segment from the same interview, where Helena remembers her father's grateful words to her after the war:

My father then, when we arrived there ... he also ... continued to work. I also continued to WORK ... and .... we managed to liberate ourselves. After independence my father was happy, he was content. "My daughter in the end you spoke well. I even wanted ... to abandon, I wanted to run away ... to Tanzania. But I didn't manage to flee because you were refusing." He was telling me: "My daughter, let's flee." I said: "No. I WANT TO SEE and hear this here. Now in Tanzania I am going to do what? My mother is there, in the village. Now Tanzania-I leave my mother to go there? I don't want, father. You go there." He also didn't go. He stayed. When the WAR ended ... he became happy saying: "My daughter, in the end ... YOU ARE WISE/SMART! YOU GUIDED ME! Today I am already someone respectable." He was also retired. He was receiving [his pension]. He only died in the year . . 2004. . that he died. ${ }^{31}$

As Helena was so young at the time, in reality, it is most likely that it was the soldiers who took care of the political mobilization of her father as she mentions in the first account. These narratives, however, point to the different ways that Helena continues to make sense of these difficult experiences and how her memories are also strongly framed by her experiences after the war. Helena's 
narrative reflects both the love and care that she remembers experiencing from both parents when growing up before the war, as well as the respected status she gained in her family after the war when she returned to them. After the war, their roles were reversed, and Helena became the person in charge, watching out for her family. As Helena herself narrates, after the war, she assumed the position of her deceased grandmother. This also reflects the societal changes that happened during the war, as the young soldiers took over the positions of authority previously held by their elders.

Other stories that Helena told show another side of her experience: the homesickness and longing she felt for her family. She spoke of how during her first months at the base, she kept thinking and hoping that "maybe when this month ends" she would return home. Many months passed like this. In 1967, Helena entered Nachingwea for her six-month training in the second group of female recruits sent from Niassa. She spoke of being so small in size that her weapon touched the ground when she carried it on her shoulder, and so she was forced to carry it on her head "like firewood." On the one hand, she remembered the strength and agility of her young body, and the speed by which she learned the new moves. On the other hand, she spoke of not being old enough to comprehend the significance of these activities. At the time, she still had no idea what war meant or that the weapons they were handling could actually kill a person. As she remembered, she was just playing around. The military training and her games with the camp mascots (a monkey called Nachingwea and a goat called Mondlane) helped to distract her from thinking too much about her family. Yet Helena spoke of leaving Nachingwea after her training with the expectation that she would meet her mother. For instance, she told the story of how for a while at the base inside Mozambique, she kept saving one of her uniforms so that she could "show-off" to her mom. She also spoke of how the Commander of DF in Niassa Oriental Teresa Amudi told her that if she worked hard for two weeks, she would be sent to stay at the base of her father. Helena remembers how she believed her and tried working really hard. In hindsight, she analyzed that this, of course, was not true, since close family members were not allowed to live at the same base. Feelings of loyalty toward blood relatives were perceived to threaten their sense of commitment and belongingness to the nationalist movement, which the political education and other socialization practices were supposed to enhance in the recruits. During the war, many of Helena's family members became recruited by FRELIMO. From her father's side of the family, eight of his nephews joined FRELIMO, and from her mother's side, her uncle studied at a FRELIMO school. Her mom also worked as a miliciana, carrying war material for FRELIMO. Many stories that Helena told spoke of the longing that she had for her family and her hope that she would be reunited with them. However, she and her dad continued working in separate bases throughout the war. And her mother, receiving false information that Helena had been killed, fled the war zone to Malawi. Helena was reunited with her many years after the war, when she eventually returned to Mozambique. 
Many soldiers lost all contact with their families during the war. They often did not even know if they were alive. Some families fled to Tanzania or Malawi, while others continued living in the mato in the proximity of the military bases. In the interview segment that follows, Helena explains why it was so difficult to get news of one's family:

There was no news ... it was forbidden. Because if ... you heard a lot of news ... about your PARENTS ... it is because ... many ran away ... pursuing their mom. So because of this it was forbidden ... one couldn't give news. THE NEWS THAT YOU COULD GIVE ... only to say that . . your mom died or one of your family members died. Then you can explain ... for not to have bad luck. They explained. Also their way of

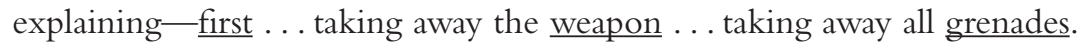
The person becomes empty like this. "Iih but why is the person taking the war material away from me? What is it that I did?" That's it, after a while people arrive to explain. [Continues in a whisper:] "Aah, in the end [I understand]." I, for example I, when my grandmother died ... they didn't want to explain to me for two months. I ALREADY - I had already lost my vision. I was going about like this, like this [demonstrates how she moved around feeling with her hands]. ${ }^{32}$

Finally, Helena was told that her grandmother had died. She continues her narrative:

So they sent me to do the [funeral] ceremony. I went and I did the ceremony ... accompanied by soldiers so that I don't flee or I DON'T kill myself. I went like this without a weapon up to two months. The third month ... they took a weapon and gave me. But ON THE DAY THAT THEY GAVE ME THAT WEAPON ... they had to give counsel. "What happened happened, let it go. You can't become sad and you can't think too much. Let's work. Death is for all of us." The person stayed ... ACCUMULATING, isn't it? [continues in a whisper] Staying like that, conversing, just like that. Hmm. . . It was very difficult to get news from home. $\mathrm{Hmm} . .$. the problem was this. Because there were others ... when they were given news, they killed themselves ... alone. Seeing that weapon ... shooting themselves. OTHERS ran away ... leaving their weapon, fleeing. Because of this they then said that you can't give news to anyone. SO THEY WENT THESE commanders, they left going to visit the family, returning. On their return: "ㅅAㄱ, I was in your zone ... I saw your family, but EVERYONE is well. They are living well all of them." "Ah, that's good." Only! ${ }^{33}$

Death came close; it was no longer something that happened at a distance. Suicide is a curiously persistent theme in her narratives (it did not feature in anyone else's stories). Helena did not mention having self-destructive thoughts, 
but her talk about the common occurrence or threat of suicidal behavior points to the intense levels of mental distress that were individually and collectively felt. It also pinpoints the level of total control that FRELIMO practiced over the combatant body but also at the same time the uncontrollability of those bodies. In another interview, Helena spoke of the first combat in which she participated and in which a group of guerrillas, mostly DFs, shot at a group of colonial soldiers who had lost their way in the bush. Helena spoke of how this was the "first day that we saw how people die." This was the only combat in which she shot her weapon. As she says, "Eeh, when I saw the people dying in that way I felt a lot. To the extent that when I returned, I was sick for two months." ${ }^{34}$ She speaks of how it affected her deeply. For a while, she had reoccurring dreams of the enemy attacking the base. The dreams felt so real that she took them as premonitions and tried to explain to the commander that the base was going to be attacked that day.

Most of the male ex-combatants that I interviewed already had some understanding of the objectives of the struggle when they were recruited, and they spoke of feelings of nationalist sentiment. All of the fifteen men I interviewed told that they had joined voluntarily. In the case of most of the women I interviewed, they only learned through the experience of the struggle, which is to say, the continuous political training and their engagement in the activities of the war, the significance of the war, and the role that they were ascribed to play in it. Many of the narratives show how it took years for the youngest DFs to understand the politics of the war. They did not know why they were doing what they were doing. When Helena returned from Nachingwea to Mozambique in 1967, she was still not afraid of the war. She often told the story of how when the base was bombed, she did not even know that she was supposed to flee. She explained to me that the sounds reminded her of the blasts that she had heard coming from a mine in her home area in Chiconono. While the bombing was going on outside, Helena continued drying maize on the fire inside one hut. Afterward, the commander of the base, who had been badly wounded by a bomb, called to have her brought to him to show her the effects of the bombing on his body. As Helena remembers, the skin on his back had been torn off completely.

HELENA: When I arrived there, he said to take off the capulana to show. So when he showed me, I FAINTED.... Then when I regained consciousness, he told [the soldiers]: "Go and leave her with the population, she hasn't grown up yet." FROM THAT DAY it was enough to hear the noise of the plane-I ran and fled! Even going to hide like this ... getting up a bit ... they already saw me. That's when I started to say that "aah, yes ... planes are dangerous. That weapon really kills people." So when ... he sent me to the population - they [the guerrillas] also came to hold meetings ... it's there that I started to understand: "Ah, he said that to liberate our country ... BUT WAIT ... he said to liberate our country, but that commander is not going to live ... that wound-now how are we going to liberate when the 
other already died?!" Like this I started to understand a bit by bit, a bit by bit ... BUT WHILE I WAS DOING ALL THIS PLAYING AROUND was when I was a section leader. To COMMAND I managedJONNA: [Overlapping speech] Hehe, but how is it possible? HELENA: Hehe. [Continues with laughter in her voice.] To COMMAND I managed. BUT TO UNDERSTAND in my head-nothing. I didn't [understand], I didn't. ${ }^{35}$

Militarization is a step-by-step process, as Cynthia Enloe writes; soon all aspects of one's life become controlled by militaristic ideas. ${ }^{36}$ Curiously, Helena speaks of even being the commander of a section and giving orders to others before she had any understanding of the war. Her narratives point to how quickly her body became militarized and how it accommodated itself to the daily routines of army life. Yet, as she herself remembers, neither the deadly gravity of the war situation nor the ideology motivating the struggle had sunk in for her. After Helena's failure to flee the bombing, she was judged to be still too immature to be working at the base. She was sent to live with the supporting population. Only after a year or so was she called back to the base. Now, as Helena describes, her "breasts had grown." This is when she slowly started to understand the war.

Living in the mato entailed a certain spatial displacement of the body, an experience of not being in one's proper place. The prewar landscape the women knew and understood was reshaped through new spatial relations introduced and enforced by FRELIMO and the war activities. The experiential meaning of home also evolved through the war. Prior to the war, family life in the home village had largely defined one's homeplace. However, during the war, families were separated from their home lands as FRELIMO moved the population into the mato, establishing new spatial relations between spaces controlled by the Portuguese colonial government and spaces liberated by FRELIMO. Moreover, as the young girls and women were recruited into the guerrilla army, they were forcefully separated from their families. Families were dispersed. Many DFs lost all contact with their families for many years, only reuniting after the war. Some DFs remembered how "home" became an unreachable location. Even if they wanted to "escape" military life and the military camps, they expressed "not knowing the path" that would take them home. Rosa Namate, for instance, told the story of how she had tried to escape from FRELIMO's educational center in Tunduru, but having lost all sense of direction of where she had come from, she ended up walking straight into the military barracks of the Tanzanian army, who immediately sent a message to Tunduru for her colleagues to come and collect their runaway. ${ }^{37}$ Helena spoke of feeling very sad and lonely when she was living with the population in Ngazelo in the area of Base N'sawisi. She did not understand why the commander had left her there. She did not know anyone there, and a lot of people there spoke Emakhuwa, which she did not understand at the time. She remembers crying and wanting to go "home to her mom" but being stuck where she was since she "didn't know where to go." Other DFs spoke of feeling that there was no escape from the war since 
their parents were still in the war zone. Often, it was not an ideological notion of national liberation that mobilized these young recruits to stay in the FRELIMO camps but the impossible idea of leaving their families behind in the war zones and the hope that "liberation" might reunite them. Cahen argues that we recognize "nation" as a "long historical process." 38 He even cautions against the definition of the anti-colonial war as a war of "national liberation." After all, the war did not automatically give rise to a Mozambican national consciousness. My interviews also point to the complexity of the DFs' sociospatial identification. Still, in a human life, ten years is a significant period, and as the war continued, the girls and young women became increasingly socialized into the military structure, and family and home gained new additional meanings. The other soldiers became like family, and even the bases started to feel like home. Several DFs even mentioned forgetting that they were in war in the quieter times when the bombings were less frequent, remembering only when the bombings started again. In these quieter times, they were able to farm machambas. They became more harmoniously attuned with the cyclical time of the different seasons. The rainy season was no longer a time of suffering from the rain without shelter. Helena speaks of a time toward the end of the war that she was "living well" at Base N'sawisi. As she explains, "At the central base those people there had organized well ... houses for officers, the DF, for men, for the commanding officer of the base. They didn't have that thing of provocation, of going to provoke other people." ${ }^{39}$ In these more peaceful times, the base was experienced as an organized social space inside the bush, its daily rhythms imitating the remembered life of the village before the war.

\section{Gendered becomings}

Intertwined into the stories of coming of age during the war is also the gendered narrative of growing from girls into women. Moreover, FRELIMO introduced new cultural scripts that framed the girls' experiences of becoming adults in the military. Young girls in their early teens were ideal recruits for FRELIMO. As Helena's quote on page 137 shows, FRELIMO purposefully recruited young girls and boys, as it considered them to be more easily indoctrinated into military life. FRELIMO's female recruits were often younger than the male recruits. Adolescent girls were preferred candidates for military training, as they still did not have children and motherhood responsibilities. ${ }^{40}$ But FRELIMO also recruited older girls and women who were already married and had children. I interviewed several women who spoke of leaving their children in the care of their maternal grandmothers when they joined FRELIMO. Often, these older DFs, similarly to the men I interviewed, spoke of their voluntary recruitment, whereas most of the younger DFs remembered being forcefully taken or abducted. In the case of all girls, but especially the younger ones (who were fresh out of nsoondo, the female initiation rite), the army experience significantly shaped their gendered trajectory into adulthood. 
As I wrote earlier, as news of the war started spreading in the communities of northern Niassa, parents had their children undergo initiation rites earlier than was customary. Although unyago (the umbrella term for both male and female initiation rites) marks the formal passage into adulthood, some of my interviewees, like Helena, spoke of participating in the initiation rite when they were still young children and before their bodies had begun to show any physical signs of puberty. Helena speaks of her unyago:

We were different. We that were small, we were only two. But the majority ... they entered into unyago when they already had breasts. Only the two of us entered unyago through hearing ... this news of the WAR. So they said: "Maybe when that war arrives we won't have time ... to put them in unyago. Now, let's just put like this even before they have grown up." (. .) I was very much a child. That's why when I was in unyago I behaved very badly there inside. I didn't care about anything, I felt NOTHING about anything that they were teaching me! I didn't feel anything. ${ }^{41}$

At the time, unyago usually lasted two to three weeks, during which the girls were kept in seclusion inside a house. Here the girls were taught about their expected future roles as women in society. My interviewees often expressed shyness at first when talking about the initiation ritual. But quickly, their stories grew braver, and their giggles got louder. It was an interesting female conversational space that men were not allowed to enter, not that they wanted to either. Through the midst of giggles and laughter, I received many small fragmented stories (not really full-fledged descriptions) ${ }^{42}$ about unyago, its rituals and teachings, and their different meanings for the women. ${ }^{43}$ When my interviewees talked about the education of unyago, they always emphasized that the most important lesson one learned was that of respect, or wucimbicimbi. This respect as they explained it entailed knowing, for instance, how to greet one's elders in the appropriate way (e.g., kneeling down when approaching them), learning to ask for permission before entering the room of one's mother or the bathroom, and learning to "speak well" with people and not to argue. Moreover, respect was narrated as a reciprocal relationship that was foundational for the existence of social harmony.

In unyago the girls were also educated on the respect that they were expected to show their husbands. ${ }^{44}$ In the following excerpt, Helena explains some of the things she learned in unyago about marriage:

HELENA: I learned ... what was most important, what the people were teaching me a lot ... was about . . . about marriage: How to respect the husband? WHEN ENTERING inside the house with your husband, you can't ... go and insult your husband.... You can't ... respond rudely to your husband. WHEN YOU GO THERE ... to sleep with your husband, you shouldn't be afraid of your husband. But even with this, people ran away. Girls used to run away! They were afraid of the man. 
JONNA: Aah, but inside unyago ... they explained well or-

HELENA: They explained well. Yes. That with your husband you will sleep like this, you will sleep like this ... and you can't run away! Because the first day you will SHOUT/SCREAM! It hurts! So every girl: "새, now they say that that it will hurt-Will I accept?" [continues with laughter in her voice] So they had to be afraid ... run away! Now for my part ... though I had already learned ... that - to GIVE water to your husband, you have to kneel. Taking a cup of water-you have to kneel to give the water. Even to your father, you have to kneel. To your mom you kneel. But ... the part about men ... as I grew up in the mato ... also I grew up ... in the mato very badly because ... I entered when I was ... TWELVE years ... into military life. This thing of going and recruiting: "Let's go to school." Fine, I went there. To school I never went. I went to stay at the base-where I got to know men. But ... in the beginning I ... I had difficulties. I went to train, I returned. Until my breast grew, until my breasts were BIG. Because I even trained before having breasts. I was very young. ${ }^{45}$

Young people were very strongly discouraged from engaging in sexual relations before marriage. ${ }^{46}$ Helena describes how it was considered a serious problem if a girl got pregnant before the traditional Yaawo wedding ceremony (known as ndoova) had been performed. The man who impregnated the girl was required to explain his actions before the chief and to pay him a fine. As Helena narrates, only on the day of the marriage could they "start to grab each other." Moreover, from the DFs' stories of their unyago experiences, it appears that most girls left unyago with a newly learned fear of sex or the "work one had to do with one's husband inside the house." Many interviewees remembered how they became scared of sex when they heard that "it was going to hurt" the first time they had sexual intercourse. As Helena exuberantly narrates, "So every girl, "Ah, now they say that that there will hurt. Will I accept?!'” She continues with laughter in her voice, "So they had to be afraid . . run away!" 47 A few of my interviewees actually told of how they had refused to consummate the marriage with their husbands on their wedding night, even though initially agreeing to the marriage. ${ }^{48}$ Some even fled to the bush and later sought refuge at their grandmothers' places. Sometimes the marriage was dissolved like this, and the girl was deemed immature and not ready for marriage. Other times, the girl would eventually yield to pressure from her family and go back to her husband. The husband could also agree to wait for the girl to grow up some more before going ahead with the planned marriage. As the Yaawo kinship system is matrilineal, the marriage contract does not involve any significant transfer of money or other goods from the husband's family to the wife's family. ${ }^{49}$ Divorce is easy and relatively common, and the decision to separate can be made by either wife or husband. As the children belong to the matrilineage, they stay with the mother's family. This gives women in matrilineal societies more negotiating power in their marital relationships. Still, the matrilineages are usually controlled by men. The most important relations of the kinship system 
are the sister-brother and uncle-nephew relations. The husband-wife relationship is less important, though as I will show, it has gained importance in the postwar period. Moreover, in the DFs' life narratives, a very significant role was attributed to the maternal grandmothers.

Girls were taught in unyago that they should embrace sex with their husbands. Based on the stories the women told, it does not immediately appear that the sex education of the unyago focused much on female sexual pleasure. At least, according to their narratives, this was not the message that the young initiates took home with them. One must bear in mind that the initiation rite is a scary event for the initiates who are subjected to various trials and general rough treatment and verbal abuse by the older women. ${ }^{50}$ Signe Arnfred, who has conducted research on sexuality among the matrilineal Makhuwa in the neighboring province of Nampula, writes that the initiation rituals are essentially the space of the older women. ${ }^{51}$ In the initiation rituals she observed, these older women engaged in erotic and explicitly sexual dances that expressed the joy of sex and female sexuality, while the initiates sat around timidly observing. Some of my interviewees spoke of how in unyago they were shown how to "massage their husbands" during sex. Still, sex education of this type was not necessarily very widespread. ${ }^{52}$ One DF Amélia Omar, who was in her twenties at the time of recruitment, strongly argued against the girls being taught anything about sex in unyago before the war.

AMÉLIA: Huh-huuh [negation]! NO, it's a lie! Huhm. I entered unyago a long time ago. They NEVER TAUGHT ME THAT! Hehehe [laughs loudly]. I entered when the [female] elders . . . the elders were still alive! A long time ago! But they never taught me that. I-I only knew when I married that man ... who was teaching me.... "After all this is marriage?" Only then! OTHERS left from inside the house ... they ran away! We ... others ran away. "Iih, no, I don't want.” Going to sleep outside. The elders when waking up ... finding her in the kitchen. "새, so why are you sitting here? Your husband?" "He is there inside." "Where did you sleep?" . . "I stayed here, right here in the kitchen." Running away from the man! She didn't know what the success of the marriage is.... IF THEY HAD TAUGHT IN UNYAGO, COULD THEY [THE GIRLS] HAVE RUN AWAY? They couldn't have run away.

JONNA: Ehh. But they didn't teach?

AMÉLIA: NO! In unyago they didn't teach. I don't know in the other provinces ... but here in Niassa. . . . I went a long time ago ... I went a long time ago. This age that I have ... it appears that I am in my seventies or ... seventy and something. ${ }^{53}$

Fear-based sex education is a way to socially control the sexuality (especially the reproduction) of underage girls who are not yet deemed ready for marriage. The younger DFs' narratives point to how fear toward sex guided their 
engagement with male combatants, especially when they first entered the army. Helena narrates:

HELENA: With the population-I only managed to stay nine months. When they were moving base from the Central Base of Ntiringwe to the Base Nakawale ... so they came to get me saying that we can't leave this child behind ... otherwise her father ... will shoot us. So, they took me to the base again. Already at this time when I was already thirteen years.... I, there at the base, I stayed a long time ... there they started to confide in me as an officer. They started to give me the responsibilities of an officer. I started to become smart, to know what ... is the life of people.... Simply I came to accept a man ... in seventy ... two ... for me to accept to sleep with a man. But in the beginning I didn't, I didn't accept.

JONNA: No?

HELENA: I didn't accept.

JONNA: But did you have problems because of these men-

HELENA: I was afraid since they had already informed me in unyago . . that these men do like this with women. I was afraid! ${ }^{54}$

Stories like Helena's were common. Later, as some of the DFs narrated, their attitude toward sex changed. They spoke of how they through experience discovered that their fear had been needless, and sex was actually enjoyable.

Helena remembers her own bewildering experience of discovering her own sexuality. The female commanding officer played an important role in her sex education. Helena spoke of being completely at a loss about her changing body as she underwent physical puberty at the military camp. In unyago, the girls were usually also taught the various rules of how to conduct themselves during menstruation (e.g., she cannot cook for other people) and how to take care of their personal hygiene. Yet girls like Helena who were still children when the war broke spoke of how they had no sexual knowledge before the war. The army was a difficult learning environment, as Helena's narrative shows:

Not even having a period. IT WAS BEFORE KNOWING! It was before knowing. I was just going about like a man. Until when my period started . . . what happened to me: I went to present this to this commander Goy-Goy. "I have an illness — send me to the hospital." "What kind of illness?" I took those pants and showed. Hehe. [Laughingly she tells the following:] I showed. He said: " $\underline{\mathrm{AAH}}$, you! You there call . . . that Teresa Amudi." [The person] called. He said: "Take this one here! Look at what she is doing?!" Teresa Amudi started to teach me. I started to feel ashamed: "Ah-aah, in the end ... that's what it is? Now what will I do?" SO I WAS ASKING: "After this will it end?" She said: "Yes, after two, three days it will end. BUT NOW LIKE THIS you are already grown up. You can't play around with a man. IT'S ENOUGH TO PLAY WITH 
A MAN-you will have a child." I, “ah.” Worse when she explained me that ... I continued ... refusing men. ${ }^{55}$

Helena broke an important social taboo. An initiated woman knows that the menstrual blood is dangerous and cannot be shown to anyone. ${ }^{56}$ Helena, however, expresses being clueless, although she had already undergone initiation. Arnfred importantly argues that repetition is a crucial part of the initiation ritual. ${ }^{57}$ Even if you are initiated only once, you often also participate in the unyago of your friends, and in this way, you are reminded of those teachings. The war, however, disrupted the practice of unyago rituals in many places. Helena speaks of how she even had no idea from where babies came. At the time, pregnancies were hidden, and the women went to the mato to give birth. Helena only saw the women suddenly appear with babies. As she laughingly remembers, she thought that babies were something that one went and bought. Even when she got pregnant, she did not know what was going on. She again thought that she was ill, and once more, the female commanding officer was the person who explained to her what was happening to her body and advised her on her sexual and reproductive health.

Officially, DFs and male combatants were prohibited from engaging in intimate relations with each other. ${ }^{58}$ This changed in 1972 when Samora Machel married a DF called Josina and lifted the ban. In my first interview with Helena, when I had only started getting to know her, the story that she chose to tell closely followed the officially acceptable narrative of male-female relations. As she tells me,

We were forbidden to be lovers. And no one ... was thinking about that. It was as if . . . as if someone took a drug and PUT . . . for us not to like each other. ONLY living! Only! ... We were all brothers and sisters ... . until the war ended. Seventy-three ... is when they started already ... the relationships. An order from President Samora Moises Machel that now you can ... the person who wants to DATE, can date. So that is when the dating began. [smiles as she speaks] Others-we returned with children.... When in seventy-three-seventy-four the war ended. We: "ㅆh, in the end it was because of this that they were saying now you can ... the person who wants, can date! The leaders knew!"59

But even though sexual relations between male and female soldiers were against the rules, these illicit affairs still happened clandestinely. In the case that a DF got pregnant, both parties were usually punished. The men (and sometimes also women) had to conduct heavy labor for weeks in a row without any rest. In the late stages of pregnancy, the DFs lost their right to carry weapons and were generally sent to live with the population until they gave birth and until their child reached the age of one. This is when they stopped breastfeeding. Then these DFs were ordered back to the base to work. Generally, the punishments that men received were considered tougher than the punishments that women 
received, and women spoke of wanting to protect the men and thus refused to give their names. ${ }^{60}$ Still, I heard several stories of how women combatants were demoted when they became pregnant. This happened to Maria Mota, and I was told it also happened to many others. Male commanders often went completely unpunished. Later, when relationships between DFs and male combatants became allowed, soldiers were forced to officialize their relationships. After 1973, those wishing to get married had to send their request to FRELIMO's headquarters in Dar es Salaam, where their documents were processed, and they then received a marriage license. After this, they could live together at the base. ${ }^{61}$ In cases where a male combatant impregnated a DF, the couple could even be forced to marry.

The DFs often expressed reluctance to talk in detail about their wartime affairs and partners. Helena argued that this was because of vergonha (shame). In the interviews, I was often told various versions of their relationship histories. A detail that very commonly kept changing in the stories was the number of children that a DF spoke of having had during the war or the number of boyfriends or sexual partners. A low number in both cases was clearly part of the preferred narrative that the women wanted to tell of themselves. ${ }^{62}$ The inconsistencies and contradicting story lines suggest the difficulty of the issue and the social pressure the women still experience to conform to dominating notions of respectable femininity. "Life narratives," as Jerome Bruner points out, "reflect the prevailing theories about 'possible lives' that are part of one's culture." ${ }^{63}$ Judith Butler also writes about the " "frames' that work to differentiate the lives we can apprehend from those we cannot." ${ }^{64}$ When telling stories about our lives, we are apprehensive of how other people will understand or judge us, and thus we systematically omit or hide certain experiences. The narrative strategies of the interviewees varied, of course, and some of my interviewees were more upfront about the different ups and downs of their lives while others (maybe also for the sake of self-preservation) made more an effort to hide or to be silent about other parts of their experience. I did not always know what to make of these narratives, and on several occasions, I found myself discussing with Helena (my co-interviewer and co-listener to many of the stories) the truth value of the changing stories. Helena's comment one day, however, helped me to move beyond my fixation on a dichotomous relation between truth and lie. She explained that as far as she is concerned, only two people had outright "lied" about their lives (by claiming that they were ex-combatants when they weren't); the others just "weren't managing to finish" their stories, and their stories thus remained incomplete. For her, the stories with all their gaps and inconsistencies were credible enough. ${ }^{65}$ Helena was also sensitive to the fact that some of her ex-colleagues had painful experiences that we had no right to press them to share.

Life stories are necessarily always unfinished. Bruner writes that the life that we tell to others and ourselves is neither "a fiction" nor "the real thing." 66 Our autobiographies, he argues, are "a continuing interpretation and reinterpretation of our experience"; moreover, they are shaped by "cultural, interpersonal, and 
linguistic influences." ${ }^{\prime} 7$ Thus the "events" of a life are not fixed in an "objective" reality. Instead, according to Bruner, they are "fashioned to fit our growing conceptions of our Selves." 68 Here, I wish to emphasize that I do not consider "life" and "narrative" to seamlessly flow into each other, and even though they feed into each other, there is a distinct "gap" between the two. ${ }^{69}$ Much of one's life experiences are not verbally expressed in any coherent way. ${ }^{70}$ And what is more, the moments when one is actually asked to narrate one's "life as a whole" 71 (like in a life history interview) are quite extraordinary. ${ }^{72}$ The autobiographical narrative is differently constituted also depending on the interactional situation in which its telling occurs; "life as a whole" is at best a momentary achievement. During our fieldwork together, Helena's own narrative about her relationship history changed from the very polished version of the first interview to stories that expressed more of the difficulties she had experienced coming of age in the guerrilla camps. The excerpts that I will look at next are taken from the fourth interview that I conducted with her at the end of the first ten-month fieldwork period. By then, she had clearly taken time to consider which kind of narrative of herself to leave with me, but also (especially since the interview was filmed) how to story herself to an imaginative outside audience. In what follows, through Helena's stories of her wartime boyfriends (and by drawing on official documents and other DFs' narratives), I explore how in different ways the DFs experienced and navigated their sexualities and sexual lives in the army and the military camps.

Helena speaks of having her "first boyfriend" in 1972. This is when, as she narrates, she first "accepted to sleep with men." Preceding this announcement, Helena has talked a lot about the difficult time she had in the beginning when she was deemed too young and sent for a while to live with the population. She returned to the base when her body had fully matured. She also speaks of how at this time she was slowly starting to understand "what was going on in the world." But it was only after some time at the base, when she had already been entrusted with responsibility, that, as she explains, she had her first sexual experience.

HELENA: The first boyfriend ... I didn't accept because I liked. I went to take a bath in the river. SO there was another man ... he pursued me there! I didn't see! My face covered in foam, I am taking a bath in the river. He just took hold of me! He started to assault me. I SHOUTED! The people then, when they heard that yell, they thought that I had been captured by the enemy ... arriving there they: "새, what are you doing?" He said: "Aah, this girl is refusing men for what reason? I attacked her." But when he left from there ... he left with wounds. The first time I didn't like . . . because IT WAS A THING OF ASSAULTING ME.

JONNA: Aah, but this man he was punished? He received a punishment? HELENA: Yes! He was even to be killed! . . . He was to be killed. From then ... he also stopped. I stayed like this too. ${ }^{73}$ 
She tells this story of sexual assault in a matter-of-fact tone with a very somber face. In Helena's life narratives, very few things happen to her against her will and without her playing an active role in the outcome (see, e.g., the stories of her recruitment). Whereas other women ex-combatants tend to shift more between a passive and active positioning of themselves, Helena always seems to prefer to narrate herself as the strong, "agentic being" 74 in control of her life trajectory. Helena's narratives of wartime are, of course, strongly framed by her whole life experience, and her current understanding of herself. In her narratives she often expresses a very strong sense of bodily self-determination. In a consistent manner, also in this story, she emphasizes her active role, as she describes: she shouted so loud that the others thought she had been "captured by the enemy," and fought so hard against her aggressor that it became him who was wounded in the attack (she makes no mention of her own physical injuries). The foam in her eyes, as she also explains, made her vulnerable to the attack and allowed him to take her by surprise. In telling this story now, Helena clearly fights against a simplified framing of her experience into a narrative of victimhood. This is not a story of shame and humiliation; instead, this experience is fitted into a narrative of resilience. While Helena chose to tell this story of sexual violence, she tells it as one among the many stories of her life, not the defining one.

Importantly, the story also suggests something of the social atmosphere within which the attack happened and, moreover, the underlying patriarchal structure of the army. Helena experienced that some of the guilt for getting attacked was partly placed on her for daring to say "no" ("He said: "Aah, this girl is refusing men for what reason?"). It is unclear how the man was punished in the end. Helena mentions that he was almost executed ("He was even to be killed!"), which speaks of the graveness of his crime but also expresses her anger. After that he left her alone. She was left to continue as if nothing had happened ("I stayed like this too."). These are experiences that are not easily talked about. Apart from one miliciana, my other interviewees did not speak of the occurrence of rape at the military camps. Still, while rape was not a normalized part of army life, the women's stories and some official documents suggest that some girls and women were victims of different kinds of sexual abuse during the war. The military camps were places of "sexual danger" to use Carole S. Vance's term. ${ }^{75}$ Documents show that the FRELIMO leadership took some active measures to prevent the different forms of sexual abuse and violence in the military camps. In 1972, in a document titled "Segunda Década-Novos Combates," Samora Machel speaks against male militants who are using their positions of authority to exploit DFs and other women and thus working to undo FRELIMO's politics of women's emancipation. ${ }^{76}$ Such behavior was repeatedly publicly condemned by FRELIMO leadership. It appears, however, that the issue was often presented as something the DF had to solve for itself. The DF had to control its girls better and not allow promiscuous behavior. At a conference held in Tunduru in February 1973, DFs representing Cabo Delgado and 
Niassa discussed with Samora the problems that the DF was facing; pregnancies and "promiscuous" sexual behavior were among the most debated issues. ${ }^{77}$ The DFs attending the meeting expressed concern with the sexual behavior of DFs who would disappear from their sleeping quarters to have sexual relations with male soldiers. Samora Machel argues that DFs do not join the troops to service the men in this manner. He tells the DFs that they have to resolve this issue so that the number of DFs can grow. As parents cannot, according to him, approve of this kind of behavior, they forbid their daughters from joining the guerrillas. ${ }^{78}$ Parents want their daughters to get married and start families. The DFs also discussed that engaging in sexual relations with different men ruins those chances. Samora Machel urges these "mulheres vagabundistas" (loose women) to clean up their act. The president effectively turns it into a "women's problem" that the DFs need to solve. This shows how the military bases were sites of "male privilege." ${ }^{79}$ Women had to control their behavior and movement as not to sexually incite the men. Several women spoke of how military commanders tried to use the power of their superior rank to pressure DFs to engage in sexual relationships with them. ${ }^{80}$ In the army soldiers are socialized into saying "yes," and by saying "no," as Martha Akawa importantly argues, "you violate the principle of obedience." ${ }^{81}$ For instance, Helena spoke of being punished for refusing (and she strongly emphasized the fact that she refused) the sexual advances of some of her male superiors. Another DF, on the other hand, spoke of how she had to say "no" a lot (as she was approached by men she did not like), but she claims that this did not cause any problems for her. Helena, in another conversation, moreover, talks about DFs wanting to engage in relationships with commanding officers since it meant that they could also benefit from the special privileges afforded to these men by their rank. The officers, for instance, I was told, usually ate a bit better than the rank-and-file soldiers. In this sense, the girls also exercised "tactic agency" 82 in choosing their partners. Mazurana et al. have very importantly drawn attention to the multiple and overlapping functions that girl soldiers perform in fighting forces. ${ }^{83}$ These different roles position women differently; one role can be victimizing while another can be experienced as empowering. ${ }^{84}$ From the DFs' narratives, I understood that some of the leaders of the DF played an important role in looking after the rights and well-being of their girls. In their talk, it was framed more as a question of caring than control. ${ }^{85}$ For instance, Helena spoke of how it was her job in the later years of the war as district level commander of DF to move around the different bases to observe how the DFs were being treated.

Sometime after the sexual assault, as Helena continues talking about her relationship history, another soldier approaches her wanting to start a relationship with her. "That man I accepted," she says. Together they even sent their marriage license documents to Dar es Salaam for the President of FRELIMO Samora Moises Machel to sign. However, before they could officialize their marriage, Helena was sent on mission to Tanzania for two months. When she returned, she found out that her fiancé had meanwhile gotten another DF pregnant. As she narrates, when she discovered this, she refused to marry him. 
She is also adamant that the reason for this was that she did not want to jeopardize her position of authority among her female subordinates. As she remembers telling the man: "I don't want! This chaos/disorder I don't want. I am . . . an officer. This one here . . . is my subordinate. After that to fight with me because of men, I don't want. I don't want you.' On an earlier occasion when she had spoken of her relationship to him, she had strongly implied that her separation from him could have been avoided had FRELIMO allowed for polygamy. ${ }^{86}$ But without the possibility of a formalized polygamous marriage the relationship between the two women with whom he was intimately involved was prone to conflict. The tragedy of this story is that the man ended up taking his own life. After his suicide, Helena got into trouble because he left a note saying he was killing himself because of her. As she with some dramatic effect paraphrases him writing:

I'm going to kill myself because of that girl. She agreed to marry me, but now she is refusing me. And for me to see that girl marrying another man-I won't be able to handle. Instead of committing a crime against that girl, I have to disappear from this world. ${ }^{87}$

So as they are crossing a river returning from a mission together, he throws himself into the current with all his clothes, army boots, and other gear on his body. His suicide note was found later. As Helena narrates, she got into very serious trouble, and she was first accused of killing him, though finally the issue was resolved in her favor. Admittedly Helena's story speaks of an extreme case. Still, it appears common that in conflict situations between men and women (for instance, different men pursuing the same woman) women were easily labeled as the trouble makers. And though both men and women engaged in multiple sexual relations during the war, women were often made to feel shame for "not knowing how to say no" and accepting men's advances. Even if, as the women's narratives indicate, the men were often sexually more active and involved with multiple women at the same time. After the war the "shame" of these multiple relationships was placed on the women. Here, women also took an active part in shaming other women, and based on the gossip and banter I heard in more informal gatherings, this continues even today.

After the death of her ex-fiancé, as Helena continues her story: "The first one who was assaulting me ... returned again. He continued again to pursue me. So I accepted: "Alright, we can marry." So they sent their relationship declaration to Dar es Salaam. Helena was already pregnant at this time. However, when he goes to work at another base, he gets two other women pregnant there. Helena, after finding out, no longer wants to go forward with the marriage arrangements. As she tells me: "When he arrives there [at the base], right, I said, 'I don't want any more to be with you. This will be the life?" Here again Helena emphasizes her own agency in deciding not to go through with the wedding. As she continues: "That [wedding] uniform came in my name. So I refused and I said, 'You can pass it on to her. For me, no. It's enough.' We separated like that, 
and he left me with the child." She speaks of how "the government" (FRELIMO) forced him to marry one of the women he had impregnated because, according to Helena, otherwise he "was going to get used to doing like that." ${ }^{8}$ Helena was left to take care of her child on her own, and he never helped her in anyway. A year after she had given birth to her first daughter, another man steps into her life. In the following excerpt, Helena speaks about their love affair, but also the difficulty of being in a relationship during the war:

HELENA: There in N'sawisi ... there in the mato ... yes, in the time of the war ... where we started to date. And ... that time it wasn't allowed to date . . . and to stay at the same base. You have to stay at a different base . . until preparing the document and sending ... to ... Dar es Salaam. So President Samora Moises Machel gave permission: "You can date, you can realize your marriage/wedding." So the government used to give all the wedding material. As we didn't have money-where to get? So our money ... came from the government . . that merchandise that they brought. For you to realize your wedding. That's it. And we lived together. It was difficultto date it was difficult . . . it was very difficult. Because you couldn't [be together] however you wanted ... you would be imprisoned. Hmm. "You want to destroy the war." Hmm. "You want to destroy the war."

JONNA: Who spoke like that?

HELENA: The president. Hmm . . . the president. And the person when they want to date ... have to date and the man has to prepare the document ... to send to the commander. SO the commander called ... the girl to ask if she agrees or not? If the girl says that I also agree. I love this man. Then also ... she has to make her declaration. So these are put together. When they are put together, they are sent to Dar es Salaam. In Dar es Salaam when the president sees that document ... he also has to give permission: "I agree. You can realize your marriage." So ... he also gives notice to the commander: "You have to get this, this, this, this for these people to have their wedding and ... let them live together." If he doesn't allow then you just continue like that. Eeeh! Huh. BEATINGS! . . . They would beat. A person would be prisoned. ${ }^{89}$

During wartime, it was very difficult for a couple to date, since it was against official rules, and they had to meet each other secretly. Only once married could they live together at the bases. ${ }^{90}$ This (heterosexual) nuclear family based on the idea of "militant love" was the family ideal strongly advocated by FRELIMO. At the First Conference of OMM in 1973, it was agreed that one of OMM's principal tasks was to promote a new conception of marriage and home built on militant love so that every home could better contribute to the Revolution. ${ }^{91}$ Arnfred argues that FRELIMO's family model was closely related to the Christian family model, and though woman was considered man's "companion," man was still considered the head of the family. ${ }^{92}$ Still, as discussed at the Tunduru Conference in 1973, it continued to be difficult for 
DFs to obtain authorization to get married; it was easier for those in charge than rank-and-file soldiers. ${ }^{93}$ Political education was later given in favor of marriage. FRELIMO advocated that if two people had feelings for each other, they were to request permission to marry from the liberation front. Militant love by definition was supposed to unite two people equally in their love for each other and the Revolution.

Though I do not want to downplay the experiences of "sexual danger" that was an aspect of the "female sexual universe" 94 in the military camps, I also want to bring attention to narratives of female sexual agency, intimacy, and pleasure. Many of the DFs had their first sexual experiences during their time in the army. Some spoke of how they moved past their initial fear of sex and discovered their sexuality as a positive experience. Several DFs laughingly remembered how they had "played badly" ("brincávamos mal") at the military bases. This meant that they had out of their own will engaged in affairs with male comrades, often without a commitment to a long-term relationship. Feminist scholars writing on African sexualities have in recent years argued that we should be wary of framing female sexuality in an overarching narrative of male subordination. ${ }^{95}$ This is an important point to keep in mind also when looking at sexuality in the context of war. In this literature, women are far too often positioned only as the disempowered victims of sexual violence. ${ }^{96}$ But their sexuality cannot solely be framed through victim narratives. As Vance powerfully argues, women's lived experiences of sexuality contain "elements of pleasure and oppression, happiness and humiliation." ${ }^{.97}$ In their stories, the women often spoke of their own agency in seeking intimacy, companionship, caring, and respect. Helena and Beatriz had an interesting conversation about these issues during Beatriz's interview situation. They spoke of how Beatriz, who was a bit older and already had a child at the time, counseled Helena on questions of finding the right partner with whom to share sexual intimacy:

BEATRIZ: So the relationship was like that. SHE even sometimes . . confided like ... to say that ... she grabs me - it can be secretly-saying that [continues in a whisper:] "Listen, there is a man X who's trying to win me over, can I accept?” I, WHEN I LOOK LIKE THIS: "Haah!” [makes a disapproving sound and then bursts into load laughter] Hehehehe.

HELENA: [Helena joins Beatriz's laughter and responds laughingly:] It was exactly like that.

BEATRIZ: Yes! So that is to confide, because the other didn't know. So you have to listen, and take advice ... on whether it is $\underline{\mathrm{OK}}$ or not.

HELENA: She taught me: "You are an officer, aren't you?" I said, "yes." "All of us here are trusting in you." "Yes." "You can't go/engage with men in whatever way ... it will get ugly. You will not be officer. You are going to be ... CAMARADA always. Because of this you have to respect your body. Find a man like this that will also respect your body." I accepted what she was saying. Hmm. ... [changes into a much loader voice:] Moreover ... the

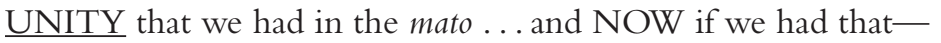


BEATRIZ: $\underline{\text { Ih! }}$

HELENA: [Continues to speak in a load voice] We would be respected/important people! EVEN THIS GOVERNMENT WOULD-WOULD BE AFRAID of us. But now other things — we are PROVOKING ALONE! We are not securing one another! Because in the past the child of this here can be my child. She [the mother] isn't here, or is sick. I take her child, breastfeed ... and carry on my lap. MY CHILD HERE, the child of this one here, on the lap. Not leaving behind! No one can know that this child is someone else's! Only after the mother comes back. "Ah, here he is, your son. Let me rest now." 98

The female sexualities expressed in this exchange cannot be theorized through a narrative of male subordination. Rather, the two women privilege female agency and control over their own bodies and sexualities. These kinds of counternarratives, as Bakare-Yusuf befittingly writes, question the "supremacy of male desire, power and control." 99 With laughter in her voice, Beatriz remembers how Helena would occasionally confide in her when a male soldier was showing interest in starting a relationship with her. She would ask Beatriz's advice whether she thought it a good idea for her to get involved with the man. And as Helena recalls, the advice that she got from Beatriz at the time was to "respect your body" and to "find a man who also respects your body." On the one hand, this conversation evokes normative notions of "respectable" female sexuality and the sexual danger of having multiple partners, especially because of the negative consequences this can have on a woman's military career. On the other hand, it also highlights female sexual agency. It points to how the DFs navigated and negotiated their intimate bodily space in this highly patriarchal institution. ${ }^{100}$ Some of their wartime relationships were abusive, others left good impressions. Rosa Chalamanda, for instance, still remembers her wartime boyfriend with affection. They were separated during the war when he was moved to a different base. As she recalls, he had respect for her and treated her well. He belonged to a group of male soldiers from Zambezia at Base N'sawisi that the DFs there especially fancied. They had a "good attitude," as Helena later mentioned, and "they knew how to marry." Moreover, many interview accounts, like the previous interview segment, speak of the importance of the female-female relations within the DF community in the military camps. In the absence of their female elders (e.g., their grandmothers), the older DFs who already had children advised the younger ones on how to "care for themselves" and how to expect this kind of respect from their partners. In Helena's narratives, "respecting oneself/one's body" is furthermore linked to a gendered trajectory of "becoming": becoming an adult, a mother, and then a grandmother. This respect is expected to increase with age. As the conversation between Amina Ndaala and Helena on pages 91 and 92 also shows, this respect involves both the experience of one's changing gendered position in society and one's changing relationship to one's own body. In the next subchapter, I will continue to explore the DFs' military tasks and 
movement and especially how motherhood influenced and was influenced by one's military engagement.

\section{Marching tempo}

“During that time, I moved a lot. I moved a lot!” Helena emphatically exclaims, talking about her work during the wartime. She did not stay at one base for long but was constantly traversing from base to base on different missions. In the beginning, she worked in the area of security intelligence, which involved carrying secret documents to and from Tanzania. As she describes, it was a very dangerous job:

HELENA: Because $\underline{I}$ have to take the secrete ... document.. hide $\ldots$. without anyone knowing that I have this letter. I have to take it directly-if it is to the president - I have to go straight ... to him. "Here is that letter, here." So he OPENS ... reads that what is written and then writes back ... he then takes it and gives it to me ... to guard. I go. And no one can know that I took that letter!

JONNA: But going where? To where?

HELENA: For instance, we ... we took the documents from the central base ... to Dar es Salaam. And taking again from Dar es Salaam ... to the central base. The president there signs. He prepares his documents and signs ... and we take ... and hide them. Now, I, who am a woman - the documents ... I was the one to take them. Because women with those breasts ... so she takes the documents and puts, puts like this [demonstrates how she would place them under her breasts]. ${ }^{101}$

At their base, they were four soldiers working in security, and she was the only woman. As she explains, a woman's breasts worked well to hide these secret documents. She started working in security in 1969 after she had been ordered back to the base to resume her military activities, and she worked in this position until 1973, when she became pregnant with her first child. Her work did not only involve transporting secret documents but also included security work at the base. FRELIMO was always concerned about possible spies working inside the bases. There was a constant fear that soldiers who had in secret defected to the colonial army were sharing logistical information with the enemy. The security team had to be on the lookout for these traitors. Also, the security of the base had to keep watch for people who pretended to join the guerrillas while they were in fact cooperating with the Portuguese. Identifying and eliminating the "enemy within" was an integral part of FRELIMO's politics during the war, and it resulted in the use of extreme violence within FRELIMO. During our fieldwork when we were visiting the last wartime location of Base Beira (now a local histórico) in Mavago, Helena told of how people had been tortured, and even executed, based on suspicions of treason. For Helena, 
it was part of her job to spy on her comrades. As she explains, "You have to sit down to get to know - who is an enemy and who isn't an enemy, who is a good person and who is a bad person." 102 She tells that they even had recorders to gather this kind of evidence. Helena's missions to Tanzania were discontinued when her colleagues disappeared. She was part of the delegation that retraced their trail (it was a specific trail that only they used) and found their chopped up bodies and their decapitated heads displayed on bamboo sticks. Their removed intestines were placed on top. On the heads their executioners had written "cordless telephone." Helena and the others took the heads down and buried the bodies but "not too deep," as Helena describes, because they were afraid that they might also be caught. After the slaughter of her colleagues, Helena no longer transported documents to Tanzania. As she says, it was considered too dangerous for her. Instead, when President Samora Machel came to the interior, she was sent to accompany him and serve as part of his security escort during his visit in Mozambique. Otherwise, Helena's movement during this time mostly involved carrying war material from Tanzania to the central base and further to the other bases inside Mozambique.

For most DFs, the rhythm and geography of their wartime movement was largely defined by the transportation of war material (see also Rosa Mustaffa's quote on page 99). Combat, on the other hand, was not a common activity for them. As Helena says, “The female detachment didn't have a lot of program of going to combat." 103 According to Helena, usually only when the commanding officer decided that "today everyone goes" did the DFs also participate. ${ }^{104}$ Normally, the number of men participating in each combat mission was significantly higher than the number of women. Helena argues that this was so the men could "protect the women," since they did not want anyone to be captured. Helena talks of "only" participating in two combats. In the first one, she actually had to engage in active combat and shoot her weapon. FRELIMO had intercepted a message sent by the colonial soldiers to their own base. This group of soldiers had completely lost their way. According to Helena, this is why Commander Odalah determined that it was a "combat for women," since all they had to do was to go and capture these soldiers and bring them to the base. So fourteen DFs were sent on this mission, and as Helena describes, "we went there as type of men kokoco-kokoco." Helena's words show that combat was perceived as the ultimate expression of masculinity in the army (see also Chapter 2). Often, the female combatant was perceived as physically weaker than the male. Lúcia Bala spoke of how in the beginning of the war, women actually participated in combat more regularly but then a decision was made against it. According to her, the DFs were considered to be more of a security risk than an asset. Though most of my interviewees spoke of only participating a few times in combat, other DFs express different experiences. Many DFs who had worked at Base Ngungunyane argued that it had been a regular practice for them. For most women, however, when they participated in combat, they usually did not participate in the shooting. They carried the ammunition and guarded the ammunition in a secure location at a distance from the male 
soldiers who engaged the enemy with fire. When the men ran out of ammunition, they would run over to the DFs to replenish their supplies. This was also Helena's role in the second combat in which she participated. Helena tells about this combat:

Then that other, the second time when I went, I didn't fire [my weapon] as I was pregnant ... with this my daughter... The late Manuel Manjice said: "Ah ! Here, the one who is pregnant, the one who isn't-LET'S GO!" Hehehhe [laughs out load]! [Continues to laugh as she narrates:] He said, "let's go!" "I'm not afraid! It's also good to go." So commander Bulvalo said: "No.... These here can come there, to leave the ammunition ... and return to come sit by that other river. We will engage in fire combat. When we will retreat, then we will pass by [the river] to bring [the women] here to the base. They can't [shoot] ... WORSE THIS ONE HERE ... when she fires [her weapon], when she will be startled, the pregnancy-there won't be any [pregnancy]. She will lose [the child]." We were saved like this. ${ }^{105}$

Apart from the transportation of war material, as I mentioned earlier, the other important job that the DFs had was that of mobilization. They mobilized both the civilian population and their male comrades, as Helena describes:

The work of the female detachment was to mobilize the PEOPLE ... and to mobilize the combatants. WHEN THOSE MEN WANTED TO FLEE . . . we said: "Huh-huh [negation], listen, you can't flee. THOSE THERE came to deceive us ... it is so that we would flee ... and leave our riches with them. And ... those are things that we don't want! It is good ... to strengthen ... bite your teeth! And kill those there. UNTIL they flee!" And we managed. And there were many combatants who fled.... IF LEFT AT THE BASE ... WITHOUT FEMALE DETACHMENT, that base is going to be destroyed. They ran away! Others fled to the central base, others to Base Beira ... others went to other bases ... "Eh, no, this war is hurting." BUT JUST TO ARRIVE WHERE THERE ARE WOMEN THERE ... no one fled! .. . No one managed to flee. They went to war/

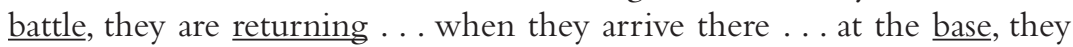
give their report, there standing in formation, done. Destrussar [sic; meaning unclear], that's it. APPROACHING them there and sitting down ... conversing with them, conversing, conversing! That's it. They also . . . become like this ... become like this happy! We are working WELL. That's it. That was our work. ${ }^{106}$

Political mobilization was officially recognized as the DFs' most important job during the war. ${ }^{107}$ And as Helena's account shows, the DFs took great pride in this. Helena herself, as she also continued her political work after the war, was clearly a very experienced and convincing mobilizer. This is something I personally noticed, especially on our travels in the different districts. Sometimes 
when we ran into a problem, she told me to wait for a moment so that she could go and "mobilize" (and she used exactly this word) someone to help us out. And she was often impressively successful. She made people feel good about themselves, and they often very happily came to our aid. I was also a target of her mobilization. She would speak about the importance of the work I was doing and of the courage and persistence that it demanded. Through her regular interventions, I came to understand a bit more about the different meanings of mobilization. On the positive side, it can be considered an empowering act that can enforce the persons involved. This was a skill that was also noticeable in many other DFs, especially the commanding officers. During the war, mobilization involved convincing people of FRELIMO's politics; it had to do with political propaganda. But at the same time, its goal was to give soldiers the courage and strength to continue the fight (and survive), despite all the difficulties.

In army rank, Helena progressed from section commander to platoon commander, and, finally, she held both the position of district-level commander of DF and the position of commander of the Josina Machel Child Care Centre (Infantário Josina Machel), ${ }^{108}$ which at the time was located on Mount Matequenha. This is how she describes her movement as the district-level commander of DF:

It is because of this that I had a lot of movement . . . a lot of movement. I had to arrive at each base to see the female detachment. Hmm. What is the DIFFICULTY, how are they LIVING, how are they BEING CONSERVED ... by these commanders, commissars . . . other soldiers. How are they conserving themselves? Hmm. If I find the situation of those DFs [to be bad], I have to organize a meeting with everyone ... with all the soldiers that are there, men and women. ${ }^{109}$

According to Helena, her level of movement between the different bases continued intense also in her new job. In fact, as she narrates, only having her first child changed the rhythm of her movement and slowed her down. In the following interview segment, Helena speaks about her experience of becoming a mother during wartime:

Iiih. ... just like that, suffering ... running from one side to the other. That child was born ... in seventy-three ...6th of June ... the first daughter. . . . But ... there was suffering. I could no longer ... manage to run. And ... I was disarmed ... of the uniform and the weapon-of nearly all the material of war. And they brought gowns, capulanas ... for us to use. WE USED like that. As we had already gotten used to trousers ... to put on a DRESS and to move about like that ... it seems/feels like you are going naked... like you didn't wear anything at all. Hehe. But ... after a while, we got used to it. That child is the one who is in the machamba. ${ }^{110}$ 
I ask Helena if having a child changed her life in some way. Helena replies,

No. When you are disarmed while you are pregnant ... so you have to stay ... until the child is walking. When you see that the child is already walking, the child was ... taken to ... the child care center. So leaving the child there at the nursery ... you continue with your uniform and your weapon. You go ... to combat. (. . .) I did exactly like that! NOW I: This one [referring to the child] when she was growing and when she was walking - the war also ended! This one was born in seventy-three ... seventy ... FOUR ... the war ended. AND THE WAR ended when I was ... at that place, at the hospital ... when I was already ... wounded.... So I returned from there when the war had already ended. ${ }^{111}$

Horace Campbell argues that out of all the southern African liberation movements, FRELIMO was especially persuasive in using the symbol of the mother as guerrilla fighter in its political propaganda. ${ }^{112}$ The importance of this symbol in official discourse explains its persistence in some of the DFs' narratives. Helena herself occasionally evokes this idealized image of the combatant mother who carried her child in front (in order to be able to breastfeed), rucksack on her back, and her weapon swung on one shoulder. According to Helena, it was normal to lose one's rucksack, but the two things that one could not lose were one's child and one's weapon (the penalty for losing one's weapon was death). Yet the other DFs' narratives (and Helena's later stories) point to the fact that that this was an idealized image rather than a lived reality. The women's narratives of their personal experiences do not evoke this image of a "can-doeverything superwoman"; ${ }^{113}$ rather, their narratives speak of the difficulty of combining motherhood with their military duties. The role of mother and the role of soldier often appear in an uneasy relationship in the DFs' narratives. As I learned, it was uncommon for DFs to carry both their weapon and child at the same time. When a pregnancy was so far along that it hindered the performance of one's military activities, the DF had her army uniform and weapon removed from her, and she was sent to live with the civilian population. The DF stayed there until her child turned one (or about the age that they could walk), and then she was called back to the base to assume her military duties. The child was sent to the nursery to be taken care of by other DFs. ${ }^{114}$ This was part of Helena's duties during the war as the commanding officer of the Josina Machel Child Care Centre: to guard the safety of these children. In the case of an attack, the children were her priority. She often talked about one devastating attack on the base during which she had to flee carrying four children strapped around her body. She speaks of how these days, she has no idea how that was even physically possible, but at the time, she managed. In the same attack, they lost three children who were never again found. When the DFs talked about the movement they did with their children in the war, they often spoke of the horror of running with one's child, or momentarily losing them, when having 
to run for cover. For instance, Beatriz Assima remembers dropping her child in a river during one attack.

Those DFs who had many children during the war spent fewer years on active duty at the base. Though all the women I interviewed spoke of returning to the base after a one-year (maternity) leave, official documents show FRELIMO faced serious problems with DFs who after giving birth tried to avoid returning to the bases. ${ }^{115}$ Due to pregnancies and births, the number of effective DFs was very low in comparison to the number of women who had received training. In one communiqué, it was lamented that sometimes out of sixty DFs, maybe only fifteen to twenty were on effective duty. ${ }^{116}$ The others were prevented from assuming their military duties because of pregnancies and caring for their babies. This was defined as a grave problem by the liberation front which, sought different ways to reintegrate these women into political work. Helena herself spoke quite accusingly of DFs whom she argues do not have "history" because they spent so much time getting pregnant and taking care of their babies.

How will she have history? She didn't flee the bombings. She didn't suffer the attack on the base. How will she have history? ... It's very difficult! The one who managed to have history it is because ... she suffered, she trained in Nachingwea. Starting when she was going ... being attacked on the way. She went there, trained. Returning, being attacked on the way. Arriving at the base, being attacked all days ... at dawn, at four in the morning ... she is fleeing! At four in the morning-AT THE BASE she has to get up at three. Every person wakes up ... packs their rucksacks, goes to hide, returns to sit with their weapon.... This person has history ... because she suffered! Now a person who arrives there, right away pregnant. She stays there with the population with a hoe ... cultivating. IT IS THE SAME hoe that was at her mom's house. It is the SAME hoe! Until the war ends ... only staying there with the $\underline{\text { hoe }}$ and with child. IT IS THE SAME HISTORY SHE HAD WITH HER MOTHER! Hum. It's very difficult! TO FINISH all the history-to break "pwaa!"- it is difficult. If you didn't see a lot of suffering. ${ }^{117}$

Helena's own motherhood was put on hold during the war. Though she expresses pride of having a lot of "history" because she fully participated in military life, her words also suggest a slightly bitter attitude toward the women who according to her had an easier experience of the war, living much of the time with the population and not at the bases. On another occasion, Helena speaks of how she herself was not so "lucky" as to be sent to the population to be with her child. Instead, she continued at the base until she was wounded and was sent to Tanzania. This is when she had to leave her child at the nursery. This was already toward the end of the war. Helena stayed in Tanzania for six months until her leg had healed, and she could "run again." She returned to Mozambique after the Acordos de Lusaka had been signed. When the war ended, the DFs who had children were finally given authorization to go and 
visit their children at the nurseries. As Helena recalls, she was "the first to go." As she says, "I had a lot of love for that child." 118 She remembers how she did not recognize her child at first because she had grown so much. The officer in charge had to indicate which child was hers. Pregnancies were generally spoken of as wanted, even though they were not planned. ${ }^{119}$ Often, the women spoke of being very surprised to discover that they were expecting a child. But still, they talked about becoming happy with the news. Through one's cultural upbringing, motherhood was construed as an integral part of the gendered life trajectory of a woman. "Exalting motherhood" in this way, as McClintock argues, often makes it difficult for women to imagine other possibilities outside the heterosexual family. ${ }^{120}$ As the war prolonged, and the girls grew older, many of them aspired to become mothers. Still, as many women described, during the war, they did not get to fully become mothers but had to in many ways postpone motherhood until the end of the war. The predominant narrative was not that of a militant mother. In their narratives, the images of women as combatant and mother were thus not tightly interwoven; rather, it was a relation filled with contradiction. Becoming a mother significantly changed the rhythm of one's military engagement — at times halting it completely.

\section{Independent life rhythms}

Helena was at the Central Base of N'sawisi when Mozambique finally gained independence 25 June 1975. "I was supposed to go to Maputo," she explains to me, "but I had a baby. So the movement that one was supposed to go and do in Maputo was to crawl and shoot. So I with child, I saw that I'm not going to manage." ${ }^{121}$ Helena speaks of realizing that the independence celebrations were going to be very noisy and dangerous, as the soldiers were going to fire their guns into the air. So she sent another DF in her stead. Helena did not stay long at the base after independence. She got married in a military wedding ceremony in Majune the same year, and soon after she followed her husband to Nampula (see Maps 6.1a and 6.1b on page 183). He was a military nurse, and he had been appointed to work at the military hospital there. As his wife, Helena was expected to follow her husband and adjust her movement to his. She explains:

HELENA: Just to be married ... you go with your husband. Our president, the first president ... forbad a married woman to stay elsewhere ... away from the husband. He forbad. She will cause trouble/chaos [confusão].

JONNA: Aah. How? Hehe.

HELENA: [Continues with laughter in her voice] AND SHE HAS TO GO WHERE THE HUSBAND GOES-THE WIFE THERE ALSORUNNING there! You have children, you don't have children-GO! "You accepted to have a husband?" "Yes." "Go!" 122

Helena speaks of willingly following her husband. She fondly remembers the years that she spent in Nampula as "the time that she was living well." Helena 
first worked at the military hospital until she was demobilized in 1977. According to Helena, it was her husband who requested that his wife be allowed to "rest already." 123 In practice, this did not entail big changes in her everyday activities, as she continued working at the army barracks. At the time, she and her husband were already living outside the military compound. About four years later, her husband was transferred to Beira, and again, Helena followed in his tow. In Beira, they both had the chance to study at the school for military officers (escola dos quadros). Helena talks of this as a very important experience for her. But it only lasted a year. Her husband was again transferred. Helena remembers that she cried on the day that she had to leave. "No use crying," she was told, "you have to follow your husband." Even in this moment in her story, Helena does not question the gendered logic of this rule. Instead, she conforms to her duty as a "wife," though it clashes with her personal aspirations. This also shows, as I wrote earlier, how the new family model endorsed by FRELIMO positioned the husband as the head of the family, promoting his authority over his wife and children. Divorce also was not officially accepted. ${ }^{124}$ Thus, especially in these military marriages, the wife became more closely tied to the husband's movement.

Independence for many combatants did not signify freedom to do what one wanted. Though most DFs were demobilized a few years after the end of the war, many male soldiers continued in active duty for a number of years. ${ }^{125}$ In cases such as Helena's, the husbands did not decide the geography of the family's movement; the orders came through the military line of command. As soldiers, this control of their movement was something to which both were accustomed. When I asked Helena how she experienced returning to civilian life, she argues that she cannot really say whether it was easy or not as she did not "go to the population" to stay with her mother. As she continues to explain, "Because when the war ended, right away-I went with my husband. So always I was moving in the barracks ... until the year arrives that my husband dies, my life was in the barracks." ${ }^{26}$ Prior to the war, the home sphere of a woman in rural Niassa had been her mother's village. After independence, many DFs experienced new kinds of gendered trajectories of movement, often following their husbands as the army transferred them across the country from one place to the next. For Helena, this movement comes to an abrupt end when her husband dies in 1981. At the time, he had been transferred to Maputo, and Helena had been sent to Lichinga to wait for him to call for her once he settled down. While waiting for her husband, Helena first lives in a government house, but after a few months, she is told she cannot stay and has to find her own place in Lichinga. With her cousin's help, she manages to find a suitable plot in Bairro II (now Muchenga; see Maps 6.3a and 6.3b on page 206) where she builds her cabana; it is a short walking distance away from the army barracks where she works during the day. As the months pass by, Helena grows more and more nervous as she awaits news from her husband. She is unable to contact him despite her numerous attempts. In the end, almost one year passes before she finally receives the dreaded news. Rather uncordially, she is informed that 
her "husband died a long time ago already." Telling this story in detail, Helena expresses her difficulty in coming to terms with the way the army handled the situation. They first delayed telling her of her husband's death, and then her superiors delivered the news to her at her workplace instead of at home with her family. Helena talks of how this further acerbated the pain of losing her husband, and she describes how she "became uncontrollable, almost going crazy" with grief.

The death of her husband marks a turning point in Helena's after-war life. Helena remembers the years after her husband's death as a "time of suffering." With her husband gone, she finds herself "forgotten" by the party state and left to fend for herself.

I . . this suffering ... THERE IS A TIME TO SUFFER. And these people HAD ALREADY DISCARDED ME! ... They weren't remembering

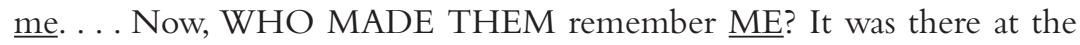
Party. There was another department head that was there ... [head] of history ... until he too died. It was he who said: "We have a DF who has a lot of memory. We want the history here at the Party!" It was he who ... searched for me and found me in Bairro II. So he started to ... take me [on missions]. It was that time that I started to recuperate little, by little, by little by little. ${ }^{127}$

Helena's story is particular in that she is later re-recruited to work for the party. Most DFs speak of their experience of being "forgotten" by the government after the war. Some DFs were even dismissed right after independence. They were told to go find their families and to return to the "life of the population." Most DFs, however, spoke of working in the army still for a couple of years before they were unceremoniously dismissed. Some spoke of receiving a symbolic amount of start-up money to help with their reintegration, others said they did not even receive that. No educational programs, such as alphabetizing classes, were offered. Most of the DFs had no other conceivable option than to become farmers. This was not an easy transformation, as many expressed. The younger DFs, especially, spoke of the difficulties that learning these new skills entailed.

An older DF, Amélia, who already had some experience with farming when she was recruited, spoke in the following words about the adjustments she had to make when she was relieved of her government work:

Because when we received our pension ... they said that you go ... DO THAT WORK that you used to do a long time ago ... before entering the war. So it is that work that you are going to continue. So ... we others, we understood. And because of this ... when ... I got my pension, right away ... I sought a place where I am going to work ... yes. I am going to farm! To farm so that I will manage ... not to buy food. When it's the end of the month, I arrive there ... I take that which is mine [refers to her pension]. I am here at home. When the time arrives, I am in the machamba. ${ }^{128}$ 
All of the women I interviewed in Niassa are subsistence farmers these days. Some went back to farming immediately after the war, others first worked for the government for a few years. As I mentioned earlier, the ex-combatants started receiving their pensions at different times. Some, like Amélia, were lucky and started receiving this money as soon as they were relieved of their government jobs. Others had to wait for many decades (see, e.g., Celina's case in Chapter 4). Mostly, the DFs invested their pensions in their machambas (employing workforce to help them acquire greater agricultural production), in building better houses, and in their children. All were not equally successful in adjusting themselves to this new way of life. Amélia's words show that she understood that she had to continue farming the machambas, much like her parents had done before the war. Her life these days is defined by the monthly movement of coming to Lichinga to receive her veteran's pension but also the rhythms of the machamba: when it is time to plant or time to gather the harvest, she moves to live on her machamba (which is far away from town). Amélia also speaks of how this was not an easy adjustment process for all combatants after the war. Those who were older and who had experience with farming before the war managed better to adapt to this way of life. In any case, most DFs sought to reestablish the prewar relationship of farming that their parents had had with the landscape.

When I ask Helena what kind of expectations and hopes she had for her life at the time when the war ended, she tells of her aspirations and desired movement after the war:

During the war ... What I was thinking was that when the war ends, with these promises ... I am going to have a house.... And I am going to open a machamba ... I will have workers ... to help me. And my children, the same as my mom, they won't have suffering. I am going to take my mom and put her inside my house ... so that ... I can manage to help from close by. But ... I didn't manage. Until today even a house I don't have. A machamba I HAVE ... but ... NOW, as I am talking, the machamba is already dead ... through [certain people] causing me TROUBLE. And I didn't manage ANYTHING - almost nothing that I managed. Yes. [continues in a very quiet voice] I didn't manage. Hmm. Because I don't have anything. ${ }^{129}$

Helena's memories of what she hoped from her life at the time are colored, of course, by her experience of how her life unfolded after the war and especially her experience of the quality of her life these days. During the first years of independence when she was still living with her husband, she did not farm; instead, she worked as a nurse's assistant. Then when Helena returned to Lichinga, she worked at the army barracks for the first years sewing army uniforms. She got accustomed to a "good life" living with her husband. As she remembers, she had "everything she needed in Nampula." In Lichinga, her children struggled with the plain diet of beans and ugadi. Later, the quality of her life improved as the party remembered her again. Her former superior officer in 
the army called her in to help with gathering the history of the liberation struggle, and thus she was again immersed in the party structure and network. When meeting other DFs in the districts, especially those who were not yet receiving their pensions, Helena often counseled them about the importance of being active in the party and ACLLN meetings. Otherwise, as she argued, they would continue to be forgotten and miss out on good opportunities.

Helena's relationship with her current home city has been a turbulent one. Helena arrived in Lichinga in 1981. The first sixteen years she lived in Bairro II. When she was "remembered" again by Frelimo, she started working in security and later for the history department of the Provincial Office of the Ministry of Combatants. However, she says it caused jealousy among her neighbors (many of whom were ex-combatants) to see the government car come and pick her up for missions and to see her living conditions improve. Helena describes how she even caught people wishing her harm and "putting drugs (droga)" inside her house. She says that she grew afraid that "someday people would enter her house with knife to kill her." In my other interviews, I discovered that bad relations with neighbors was one of the main reasons that people wanted to relocate to another neighborhood or village. They often accused these neighbors of applying witchcraft (Ciyaawo: usawi [Portuguese: feitiçaria]), for instance, using citega (pl. yitega $)^{130}$ to bring them bad fortune, especially ill health. This behavior, they argued, was motivated by envy for succeeding better in life than them. Witchcraft can also be understood as a reasonable way of dealing with the chaos and misfortunes of one's life. ${ }^{131}$ Knowing the cause of one's troubles can help a person to gain control of one's life and fortune, either through protective medicine or by moving away. ${ }^{132}$ For Helena, the negative social atmosphere of the place became so bad that she decided to move away to Namacula, a growing neighborhood situated at the edge of town (see Maps $6.3 \mathrm{a}$ and $6.3 \mathrm{~b}$ on page 206). She has now lived eleven years in Namacula, and though she experiences that it is a bit far away (that is, a thirty-minute fast walk) from ACLLN, the party, and the government offices, she says she is living well there.

Here I am well. I don't have problems with neighbors. ... Always I am living well. ... Even when I am away a lot, the day that I return-All of those trips ... when I return there, everyone approaches me. "Iih, you travel a lot! You travel a lot!" I have no problems. I have already lived ELEVEN years here. But I don't have problems with anyone. ${ }^{133}$

Still, when I ask her to compare it to her life in Nampula, she argues that it still does not come close.

HELENA: Here in Lichinga? I feel well. But it is not like in Nampula. JONNA: Aah, Nampula?

HELENA: Nampula is where I lived well. Yes. In Nampula I lived well. . . But $\underline{\text { here- }} \underline{\text { ah}}$, no. .. . I live because ... it is in my homeland, isn't it? And my 
mother is close and also she is already old ... it's not possible to leave her

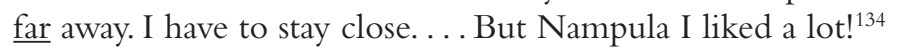

For Helena, her homeplace, though it centers in Namacula and Lichinga, encompasses the whole province of Niassa. Her childhood homeplace is in Muembe, which in the dry season is a few-hour-long chapa ride away from Lichinga. It is close enough for her to go regularly to visit her remaining family there. Helena tells of how when she first went to look for her family after the war, her mother was still in Malawi thinking that Helena had died. It took her two years to return to Mozambique. According to Helena, her mother could not believe that Helena was still alive. Even when Helena sent her a picture of herself, she did not accept that it was her; she looked so different: a grown woman in army uniform. These days, Helena has a loving relationship with her mother. As she describes, "My mother is a very close friend with me." Still, she argues that she does not miss her childhood landscapes.

HELENA: Hehehe. [Continues to laugh while speaking:] AAH-AH! That place, no, I don't miss! Now no. Only to go and visit people and return. Not to stay ... for a long time, no. The life that is there is difficult!

JONNA: Okay. Can you explain how it is difficult?

HELENA: Hehe. It's difficult! To go work on the machambas it is far ... to go cut firewood, it is far. Because those trees that we used NO LONGER EXIST THERE! They finished. Now only those pines are left that those whites planted. Also they are few! They are not many. Hmm. ${ }^{135}$

After the war, Helena got accustomed to an urban lifestyle. She says she would not be able to adjust herself to the village way of life anymore. The way of preparing food and the idea of cleanliness, for instance, are different. Her only tie to the landscape of Muembe is her family. In the time before the war, Helena did not even know the locality that is now called "Muembe sede," which is the administrative center of the district that goes by the same name. Her mother's brother, however, lived in Muembe throughout the war. He is the reason that Helena's mother moved there when she returned to Mozambique. She now lives relatively comfortably in Muembe on her veteran's pension that Helena helped her to get. During most of the war, she worked as a miliciana before she fled to Malawi. A few years ago, she was able to build a casa melhorada in Muembe and now lives there with her remaining children and their families. Once a month, she makes the trip to Lichinga to collect her pension at the bank with the other ex-combatants. ${ }^{136}$ For Helena, to be in Niassa is to be in her homeland (terra natal). A similar conceptualization of homeplace comes across in the interviews of other DFs. Home continues largely to be defined through family. The only difference is that one's sphere of movement has broadened, and the experience of distance has changed.

The most important family for Helena, apart from her mother and siblings in Muembe, are her children. She had her first child during the war, her second in 
1975, and her third in Nampula in 1977. After her husband died, Helena never officially remarried. Since he died in Gaza, she did not manage to obtain his death certificate and annul the marriage. But she lived for seventeen years in a polygamous relationship with a man who had three other wives. Helena talks of it as a happy relationship:

Hmm. With him I also lived well. Hmm. Because he had the control of ... of a man-controlling his wife, controlling the children! And . . BUT I don't have a child with him! But these children, as he met them when they were small like this ... so the children, also this Emilia [her youngest daughter] ... as she didn't know her father ... so she knew him [as a father]. Aah! She got to know him, growing up in his arms. Even these grandchildren she got in his arms. ${ }^{137}$

Helena is clearly satisfied by the way he performed his gendered role in the family as husband, father, and grandfather. As she says, "He really had the control of a man." Her words also point to her understanding of the husband as the head of the family. This shows an interesting shift when compared with how she talks about the authority of her maternal grandmother in her childhood home (see page 131). Apart from FRELIMO's family politics, neolocal living arrangements also contributed to the seeming increase of the husband's authority in the family. Still, polygamy continued strong after the war, even despite Frelimo's campaigns against these "traditional" practices. Polygamy itself was not an issue for Helena, but she speaks of how her relationship with this man ended because the youngest wife started playing "games" and manipulating the husband and controlling him through witchcraft. ${ }^{138}$ This, according to Helena, led the husband to separate from all his other wives, including her.

A few years after separating with this man, Helena engaged in a relationship with another man. But though they stayed together for seven years, Helena describes it as a relationship that did not quite work for her benefit. Helena is critical of her husband not contributing through his labor to their common wealth. As she describes, he took from what she earned and distributed to his other wife. After separating from him, Helena has not engaged in a serious relationship with anyone else. She insists that she has "had enough" of the "life of attending men." As she explains,

The man also has to work, right? He has to ... make an effort ... in order to have. NOT to CONFIDE/RELY only in the woman! Saying that this one here receives [a pension] ... she will bring and I WILL EAT. No. With me no. I usually ask: "You there, in your house where you lived . . you didn't farm?" "I farmed." "You didn't sell?" "I sold." "You didn't make money?" "I did." “And here? What will you eat?” Not even a blanket does he bring! NOT EVEN the shop where they sell capulanas for his wife-he doesn't know! So go there and stay. AFTER you learn you will come and marry me. ${ }^{139}$ 
Also, other DFs that are widows and divorcees spoke of the difficulty they have with men wishing to marry them only because of their pension money. The expectation that comes across the various narratives is that in a marriage both wife (/wives) and husband have to contribute equally to the material wellbeing of the family. The ideal marriage is a reciprocal relationship. One cannot simply sit idly and wait for the other to provide. Moreover, with their pension money, these women are economically independent from their husbands; they do not have to rely on the husband to provide. Importantly, most of the DFs have their own houses (and I will come back to the significance of the house in the next chapter). Of course, with a "good" husband who also works hard and takes care of his family, the whole family is financially better-off (like in Helena's case with her first husband). Following matrilineal tradition, if the relationship does not satisfy both parties, either can opt out. These days, their social class affords the DFs the possibility to make such decisions. Some women even joked in the interviews that DFs do not think twice about leaving a relationship if they feel they are not getting enough out of it. Yet there are some differences between urban and rural settings. One DF living in the rural area spoke of how she prefers to stay in her marriage even if it is no marriage in any real sense, since the husband, according to her, does not bring anything to it. She still prefers to have the status of a married woman. As she explains,

\section{BECAUSE ... A HAPPY MARRIAGE ... YOU ALREADY KNOW, isn't it? You have to ... AT LEAST WE that are here in the villages ... a person has to ... at least have ... a program together with her husband ... at least ... the work like this ... helping each other like this. Each person working. If one can't handle [the work], the other, the other does. BUT IF IT IS YOU ALONE-NOT EVEN SEEING what he is doing ... hehe, $\underline{\text { ah, }}$ like that it isn't a happy marriage.}

She argues that being an unmarried woman of her age incites a lot of ungenerous gossip. Other women fabricate stories that she is sleeping with their husbands. So she prefers to stay married to avoid such gossip, even if she no longer receives any "profit" (rendimento) from the marriage. In the towns, the situation is a bit different, and women do not experience the same level of outside policing of their behavior, as Helena's talk indicates.

Still, Helena also speaks of her experience of not fitting into the cultural model of the ideal woman and wife. Helena's work takes her away from home a lot. As she describes, "I have never turned down a mission. I am always working. Because of this I already got used to it!" However, she argues that her movement causes problems with her partner at home. While he complains that she moves a lot, she complains to him that he does not move enough. As she narrates,

HELENA: Now the MAN that is at home . . . doesn't MANAGE. He says: "You move a lot! Aah, you move a lot!" "Yes, I am moving a lot-if you don't manage to provide." For you to get me to sit at home, go there and 
FIND ... and bring. I will sit. IF YOU DON'T MANAGE TO FIND ... stay there sleeping in the bed. I am off?

JONNA: And the men also don't like? Hehe.

HELENA: No they don't like. HAHAHA [laughs loudly]. "I don't want.",

During an interview that I had with a male ex-combatant called Tito, he and Helena discussed how they thought it was difficult for an ex-combatant to marry a civilian. They agreed that in such a relationship, there is "no understanding between the two." The two have learned a different rhythm and pace of living and going about their tasks. As they described, ex-combatants get up early; they do not wait for anyone, but rather take the first initiative if there are things that need to get done. Helena insists that women ex-combatants do not wait for men to work for them or control their work but make their own money to support their families. Helena also claims that women ex-combatants easily leave men who do not pull their own weight and do their own part in providing for the family. In the interview conversation with Tito, Helena speaks of how she has had difficulties having relationships with civilian men.

Always there is disorder/chaos [confusão]. "Aah, these women ... that were in the MATO they go about commanding men as if they are crazy! She moves a lot! She goes about commanding men a lot - it is as if ... it is she who is the man. Aah, these women, no! They don't have respect."141

Helena also spoke of how women ex-combatants started marrying civilian men only in more recent years.

HELENA: Even this thing of a civilian marrying a soldier . . . it started just recently! In the past, no! Even the men themselves they refused to marry those women that were in the MATO-they refused!

TITO: They refused.

HELENA: That is not a woman that one. That one is a man. So that we won't fight. ... The woman also asked: "Mr., what is the work that you know to do?"142

Tito agrees with Helena and argues that a female ex-combatant "appears like a man" to a civilian husband not used to the military lifestyle. Those without military background and the political education that accompanied it have different kinds of ideas about appropriate "respectful" behavior. "Masculinity and femininity" are, as R. W. Connell writes, "inherently relational concepts, which have meaning in relation to each other." ${ }^{143}$ Any new conceptualizations of "woman" also require the reworking of the cultural meanings of "man" for there to be any real change in a gender system. The women ex-combatants' interview talk shows how DFs engage in negotiating their gendered space in relation to the available cultural gender models. The military and the wartime socialist discourse introduced new gender conceptualizations that have little 
meaning among the broader population in Niassa. Many DFs have also chosen to play along and to perform the feminine roles that are expected of them in order to be perceived and identified as "women" instead of going against the grain and causing social disturbance.

In Helena's life narratives, movement is without a doubt one of the most prominent themes. Moreover, it often assumes the shape of the directional movement of someone who knows where she is going. Helena argues that she has gained a lot of experience from traveling so much. She also insists that it is because she has experience of moving starting from the wartime that she continues so mobile. She explains that she knows how to relate to people; she knows how to attend to people; she knows how to present people; she knows how to respond to people asking questions; she knows how to speak publicly. These are skills she learned in the DF during the war. Listening to her life stories, Helena's mobility can be described as evolving through different stages through her life. First, the geography of her war movement in the bush was guided by military orders. Second, after the war, she pursued her husband as he was transferred from one location to the next. Third, during the first years upon her arrival in Lichinga after the death of her husband, she experienced being forcefully immobilized. Fourth, her mobility increased through her work for the party and ministry, which took her around the different districts of Niassa as well as the provincial capitals of Mozambique (e.g., Maputo, Nampula, and Quelimane). As Helena proudly insists, she knows "almost all of Mozambique." The only province that she has not been to is Cabo Delgado. In recent years, however, her movement has decreased. She was not, for instance, invited to go to Pemba, the capital of Cabo Delgado, for Frelimo's congress in 2013. But she still gets invites to participate in the important meetings of OMM in Maputo, as she is an honorary member. For the past few years, Helena has not been farming her land, though she says she has a big plot in Chiwigo, about an hour's chapa ride away from Lichinga toward Meponda. Her work at the provincial office of the Ministry of Combatants and ACLLN has kept her away from her fields. I started working with Helena when she had been dismissed from her position at ACLLN. Apparently, orders had come from the national ACLLN office in Maputo that her position had to be dissolved. Helena was very bitter about the way the situation was handled and how she was sacked as if she had done something wrong. Since the rainy season had already started, she also lost her chance to farm her land that year, which would have been the alternative option for her. This is when we started working more closely together. It appears from her narratives that she is again at a turning point in her life. Disappointed by the decrease in her state- and party-sanctioned movement, she expresses a desire for both a more independent rhythm of movement and a change in its direction. She talks of her need to focus her attention more fully on her machambas and thus distance herself from the Frelimo-ordered movement that has largely controlled her life trajectory so far. Her final interview preludes a new turn in her life, or at least it expresses her hope for a new kind of rhythmic engagement with the landscape. She evaluates that her movement has 
not contributed to her personal well-being, neither materially nor emotionally. Instead, she wants to rely on the strength of her own body to cultivate the land and create its own well-being. "Mozambique," she argues, "is a good place to live. Mozambique has riches. Mozambique has everything. For the person who has strength to work, you live well in Mozambique and have everything in your house." In the following chapter, I study the significance of this statement further. More specifically, I analyze the meanings of the "beautiful/good" in the DFs' landscape experiences in order to understand what constitutes a desirable body-landscape relationship. Aesthetic sensibility, as I show, is deeply intertwined in the DFs' experience of socio-spatial belonging.

\section{Notes}

1 David Seamon, "Body-Subject, Time-Place Routines, and Place-Ballets," in The Human Experience of Space and Place, eds. Anne Buttimer and David Seamon (London: Croom Helm, 1980), 150.

2 Vance, "Pleasure and Danger," 20.

3 Lefebvre, Rhythmanalysis, 6 .

4 Heidi Gengenbach, “Truth-Telling and the Politics of Women's Life History Research in Africa: A Reply to Kirk Hoppe," The International Journal of African Historical Studies 27, no. 3 (1994): 624. See also Popular Memory Group, ed., Interpreting Women's Lives: Feminist Theory and Personal Narratives (Bloomington: Indiana University Press, 1989), 14.

5 Interview with Helena Baide, Lichinga, November 21, 2012.

6 Ibid.

7 On the social embeddedness of memory, see, e.g., Alessandro Portelli, “The Massacre at Civitella Val di Chiana (Tuscany, June 29, 1944): Myth and Politics, Mourning and Common Sense," in Battle of Valle Giulia, ed. Alessandro Portelli (Madison: The University of Wisconsin Press, 1997), 140-160; Halbwachs, Collective Memory; Schutz, Phenomenology of the Social World, 207-214.

8 Interview with Helena Baide, Lichinga, November 21, 2012.

9 Interview with Helena Baide, Lichinga, August 24, 2013.

10 Ibid.

11 Landscapes and landscape relations are continuously reworked through past memories and new encounters with the landscape. See, e.g., Bender et al., eds., Stone Worlds.

12 These days, "kwiwanda" means "south" or the "lowlands." However, in the women's Portuguese accounts, it was always translated as "em baixo" (down, below). "Kulutando" refers to the highlands, where the rivers have their source and from where they flow toward the sea.

13 Interview with Maria Ajaba, Lichinga, November 23, 2012.

14 Anne Buttimer, "Home, Reach, and the Sense of Place," in The Human Experience of Space and Place, eds. Anne Buttimer and David Seamon (London: Croom Helm, 1980).

15 Interview with Helena Baide, Lichinga, August 24, 2013.

16 João Facitela Pelembe, Lutei pela pátria: memórias de um combatente da luta pela libertação nacional (Maputo: SGL, 2012), 74.

17 Mwemedi N'tawula in group interview with male ex-combatants in Mavago, August 8, 2013. As I mentioned earlier, Ce-Mataka was a powerful ruler who for a long time successfully resisted the colonial occupation of his lands.

18 Buttimer, "Home, Reach, and the Sense of Place," 171.

19 Yi-Fu Tuan, "Sense of Place: Its Relationship to Self and Time," in Reanimating Places: A Geography of Rhythms, ed. Tom Mels (Aldershot: Ashgate, 2004), 45-55. 
20 On average, 100,000 Mozambican men per year were recruited to work at the South African mines between 1950 and 1975. Ruth First, Black Gold: The Mozambican Miner, Proletarian and Peasant (Sussex: The Harvester Press, 1983).

21 Galli, Peoples' Spaces, 29.

22 As Yussuf Adam and Hilário Dyuti have argued, before the formation of FRELIMO and before its official narrative effectively silenced other narratives, a variety of different ideas on what constituted independence coexisted. Adam and Dyuti, "O massacre de Mueda: falam testemunhas," Arquivo 14 (1993): 117-128; see also Michel Cahen, "The Mueda Case and Maconde Political Ethnicity. Some Notes on a Work in Progress," Africana Studia 2 (1999): 29-46.

23 Interview with Helena Baide, Lichinga, November 21, 2012.

24 Building aldeamentos was central to Portugal's counter-insurgency program. See, e.g., Barry Munslow, Mozambique: The Revolution and Its Origins (London: Longman, 1983), 120-124.

25 Interview with Helena Baide, Lichinga, December 5, 2012.

26 On FRELIMO's educational system during the liberation struggle see Salvador André Zawangoni, A FRELIMO e a formação do homem novo (1964-1974 e 1975-1982) (Maputo: CIEDIMA, 2007).

27 Forced recruitment still appears to be a controversial topic. Bernardo Moisés Goy-Goy, for instance, argues that there was only voluntary recruitment. Interview with Bernardo Moisés Goy-Goy, Lichinga, November 20, 2012.

28 Interview with Fátima Aquili, Lichinga, June 6, 2013.

29 Interview with Helena Baide, Lichinga, November 26, 2012.

30 Interview with Helena Baide, Lichinga, November 21, 2012.

31 Ibid.

32 Interview with Helena Baide, Lichinga, November 26, 2012.

33 Ibid.

34 Interview with Helena Baide, Lichinga, August 24, 2013.

35 Ibid.

36 Cynthia Enloe, Maneuvers: The International Politics of Militarizing Women's Lives (Berkeley: University of California Press, 2000).

37 Interview with Rosa Namate, Sanga district, May 30, 2013.

38 Cahen, "Anticolonialism \& Nationalism," 11.

39 Interview with Helena Baide, Lichinga, August 24, 2013.

40 See also Arthur, "Women in the Armed Struggle"; West, "Girls with Guns."

41 Interview with Helena Baide, Lichinga, August 24, 2013.

42 There is much secrecy surrounding the unhago and an understanding that certain knowledge should not be shared publicly. See also Brigitte Bagnol, "Female Initiation Rituals and Sexualities," in The Essential Handbook of Women's Sexuality: Meanings, Development, and Worldwide Views, ed. Donna Castañeda, vol. 1 (Oxford: Praeger, 2013), 143-165.

43 It is important to note that the cutting of the clitoris is not practiced as part of the initiation ritual among the Ayaawo. Although, as Bagnol argues, three to four generations ago, it was practiced, at least among the population in Malulu in the district of Sanga and in Malanga in the district of Majune. Bagnol, "Female Initiation."

44 Helena speaks with nostalgic admiration of the respect that she as a child witnessed her parents show for each other.

45 Interview with Helena Baide, Lichinga, August 24, 2013.

46 See also Signe Arnfred, Sexuality and Gender Politics in Mozambique: Rethinking Gender in Africa (Woolbridge, Suffolk: James Currey, 2011), 143-144, 181. Arnfred argues that while prepuberty sexual play is not prohibited among the Makhuwa in northern Mozambique, more strict rules apply when girls start to menstruate, as reproduction is only supposed to occur within the institutionalized framework of marriage.

47 Interview with Helena Baide, Lichinga, August 24, 2013.

48 The women also spoke of having a say in who they married. They could turn down suitors, though parents could become impatient with them if the girl was being very 
picky and did not want to accept anyone. Still, the marriages were usually arranged with the willing consent of the girl.

49 Though some interviewees spoke of a small symbolic payment, it is apparently a more recent development.

50 Arnfred, Sexuality and Gender.

51 Arnfred,"Feminism and Gendered Bodies."

52 Compare Arnfred, Sexuality and Gender, 144. This was common sex education in her research area.

53 Interview with Amélia Omar, Lichinga, November 29, 2012.

54 Interview with Helena Baide, Lichinga, August 24, 2013.

55 Ibid.

56 See also Arnfred, Sexuality and Gender.

57 Arnfred, "Feminism and Gendered Bodies."

58 Some women also spoke of how certain taboos were invoked to control sexual activity. One such taboo concerned having sex before combat. If one engaged in sexual activities a day or two before combat, it was believed that one would be killed by the bullets. Especially during the periods of more intense fighting, the DFs claimed that many combatants were afraid to have sexual relations. The male combatants preferred to ask for missions to Tanzania in order to "sleep with women."

59 Interview with Helena Baide, Lichinga, November 26, 2012.

60 However, Casimiro argues that women were punished more severely than men for misconduct. Casimiro, Transformação nas relações, 119.

61 According to DFs from Cabo Delgado, this was not the case there. Even after officializing their relationships, they were not allowed to live at the same base.

62 On the notion of "preferred identity," see Riessman, "Analysis of Personal Narratives." "Preferred identity" refers to the performativity of identity.

63 Jerome Bruner, "Life as Narrative," Social Research 71, no. 3 (2004): 694. See also Popular Memory Group, ed., Interpreting Women's Lives, 13.

64 Judith Butler, Frames of War: When is Life Grievable? (London: Verso, 2009), 3.

65 William Labov argues that "credibility is an essential component in the transfer of experience in personal narrative." The Language of Life and Death: The Transformation of Experience in Oral Narrative (Cambridge: Cambridge University Press, 2013), 225.

66 Jerome Bruner, “Narratives of Aging," Journal of Aging Studies 13, no. 1 (1999): 7.

67 Bruner, "Life as Narrative," 691, 694.

68 Jerome Bruner, "A Narrative Model of Self-Construction," Annals of the New York Academy of Sciences (December 2006): 147.

69 See Hyvärinen on his criticism on Bruner's "Life as Narrative.” Matti Hyvärinen, “'Life as Narrative' Revisited," Partial Answers: Journal of Literature and The History of Ideas 6, no. 2 (2008): 691-277. See also White, "Anthologies of Women in Africa."

70 Seremetakis eloquently calls these the "memories that hover at the margins of speech." C. Nadia Seremetakis, "The Memory of the Senses, Part 1: Marks of the Transitory," in The Senses Still, ed. C. Nadia Seremetakis (London: University of Chicago Press, 1996), $1-18$. Her focus is on how material artifacts have the capacity to evoke sensory memories that have been silenced in official history.

71 Bruner,"Narrative Model," 150.

72 See also Bamberg, "Biographic-Narrative Research”; Bamberg, "Stories.” Bamberg calls for us not only to focus on "big stories" but also to look at how identity is negotiated in everyday interactive situations in the form of "small stories."

73 Interview with Helena Baide, Lichinga, August 24, 2013.

74 Riessman, “Analysis of Personal Narratives," 702.

75 Vance, "Pleasure and Danger."

76 Parts of this document were cited in Journal do Centro, the news bulletin produced at FRELIMO's center for political-military training in Nachingwea. "Drama sobre a emancipação da mulher moçambicana," Journal do Centro de Preparação Político-Militar 
Ano II, no. 224 (9 April 1973): 1-3. Fundo de documentação da FRELIMO (hereafter FRELIMO archives), AHM.

77 "Actas da conferencia realizada no Centro Educacional de Tunduru no mês de fevereiro de 1973," March 7, 1973, FRELIMO archives, AHM.

78 See also Casimiro, Transformação nas relações, 115.

79 Vance, "Pleasure and Danger," 3.

80 See also Arthur, "Women in the Armed Struggle."

81 Akawa, Namibian Liberation Struggle, 138.

82 See Mats Utas, "Victimacy, Girlfriending, Soldiering: Tactic Agency in a Young Woman's Social Navigation of the Liberian War Zone," Anthropological Quarterly 78, no. 2 (2005): 403-430.

83 Dyan E. Mazurana et al., "Girls in Fighting Forces and Groups: Their Recruitment, Participation, Demobilization, and Reintegration," Peace and Conflict: Journal of Peace Psychology 8, no. 2 (2002): 97-123.

84 Ibid.

85 For instance, the DFs who served in Niassa Oriental affectionately remembered Teresa Amudi, their commanding officer, as being a very kind leader who firmly but softly guided the girls as they entered military life. Not all female commanders had this kind of reputation.

86 In one report I came across, women who had gotten pregnant to married men lamented that they could not marry because FRELIMO did not accept polygamy. "Relatório mensal abril,” Base Moçambique, May 26, 1971, FRELIMO archives, AHM.

87 Interview with Helena Baide, Lichinga, August 24, 2013.

88 Ibid. In the case that a DF got pregnant, both parties were questioned before a decision was made on the appropriate disciplinary actions, which included fines, prison sentences, and political reeducation. None of the women mentioned that they had been forced to marry, but they spoke of other DFs who had suffered that fate.

89 Interview with Helena Baide, Lichinga, December 5, 2012.

90 According to other stories, husband and wife were not allowed to stay together but were stationed at different bases.

91 Organização da Mulher Moçambicana (hereafter OMM), "Relatório da Comissão Coordenadora Nacional da Organização da Mulher Moçambicana à II Conferencia da O.M.M," in Documentos da II Conferencia da Organização da Mulher Moçambicana (Maputo: Imprensa Nacional, 1977), 29-63; See also Machel, "Liberation of Women."

92 Arnfred, Sexuality and Gender.

93 “Actas da conferencia,” March 7, 1973, FRELIMO archives.

94 Vance, "Pleasure and Danger."

95 For example, Signe Arnfred, "Sex, Food and Female Power: Discussion of Data Material from Northern Mozambique," Sexualities 10, no. 2 (2007): 141-158; Bibi Bakare-Yusuf, "Thinking with Pleasure: Danger, Sexuality and Agency," in Women, Sexuality and the Political Power of Pleasure, eds. Susie Jolly et al. (London: Zed Books, 2013), 28-41; Sylvia Tamale, "Eroticism, Sensuality and 'Women's Secrets' among the Baganda: A Critical Analysis," Feminist Africa 5 (2005): 9-36.

96 My argument also resonates with Stephen C. Lubkemann's assertion that we need to recognize and study the ways that even during conflict people's social lives and relations are shaped by a multitude of forces and not only violence. His research focuses on the social organization of life during the civil war in central Mozambique. Lubkemann, Culture in Chaos: An Anthropology of the Social Condition in War (London: University of Chicago Press, 2008).

97 Vance "Pleasure and Danger," 6.

98 Interview with Beatriz Assima, Lichinga, February 8, 2013.

99 Bakare-Yusuf, "Thinking with Pleasure," 35. We also need to bear in mind that FRELIMO understood female sexuality in "traditional society" through male domination of female bodies. Machel, "The Liberation of Women." 
100 Cynthia Enloe powerfully writes that “"militarism' as an ideology" is not built only on a certain notion of masculinity but it requires "the complementary concept of 'femininity"” to make sense. Enloe, Does Khaki Become You?, 7.

101 Interview with Helena Baide, Lichinga, December 5, 2012.

102 Ibid.

103 Interview with Helena Baide, Lichinga, November 26, 2012.

104 For instance, ex-military commander Tazama argues that only in "extreme circumstances" did women participate in combat. "Osvaldo Assahel Tazama," 629.

105 Interview with Helena Baide, Lichinga, August 24, 2013.

106 Interview with Helena Baide, Lichinga, November 26, 2012.

107 See, e.g., Machel, "Role of Women."

108 Josina Machel created the infantário in 1971 during her visit to Niassa. Nihia, M'toto, 145.

109 Interview with Helena Baide, Lichinga, August 24, 2013.

110 Interview with Helena Baide, Lichinga, November 26, 2012.

111 Ibid.

112 Horace Campbell, Reclaiming Zimbabwe: The Exhaustion of the Patriarchal Model of Liberation (Trenton, NJ: Africa World Press, 2003), 281.

113 Enloe, Does Khaki Become You?, 166. See also Jacklyn Cock, "Women and the Military: Implications for Demilitarization in the 1990s in South Africa," Gender and Society 8, no. 2 (1994): 152-169.

114 The nurseries did not exist in the first years of the war.

115 This was one of the main issues, for instance, discussed at the 1973 conference in Tunduru, but also in other reports from the bases. See, e.g., "Destacamento Feminino," Base Provincial de Cabo Delgado, 24 May 1971, FRELIMO archives; "Relatório mensal abril," May 26, 1971, FRELIMO archives.

116 Alberto Joaquim Chipande, Deputy Chief of the Department of Defense, Nangade district, to Pascoal Almeida Nhapulo, Deputy Chief of Provincial Operations, April 25, 1972, FRELIMO archives.

117 Interview with Helena Baide, Lichinga, May 23, 2014.

118 Interview with Helena Baide, Lichinga, November 21, 2012.

119 Neither did I hear any talk about abortions. Although the danger of miscarriages due to fright caused by the bombings was sometimes mentioned.

120 McClintock "“No Longer in Future Heaven," 117.

121 Interview with Helena Baide, Lichinga, December 5, 2012.

122 Interview with Helena Baide, Lichinga, November 21, 2012.

123 Some other DFs also mentioned that it was their husbands who requested demobilization on their behalf.

124 For example, interview with Maria Ajaba, Lichinga, August 18, 2013.

125 Many of the male combatant continued working in the army for several years after independence. Frelimo gave military support to the liberation struggle in Zimbabwe and was also engaged in a fight against Rhodesia-backed RENAMO.

126 Interview with Helena Baide, Lichinga, August 24, 2013.

127 Ibid.

128 Interview with Amélia Omar, Lichinga, December 6, 2012.

129 Interview with Helena Baide, Lichinga, August 24, 2013.

130 Citega (Portuguese: mina tradicional; traditional mine) was often believed to be caused by jealous relatives wanting the person to share their wealth with them. For this reason, many ex-combatants spoke of not wanting to live close to family.

131 Terje Oestigaard,"Witchcraft, Witch Killings and Christianity: The Works of Religion and Parallel Cosmologies in Tanzania," in Looking Back, Looking Ahead: Land, Agriculture and Society in East Africa: A Festschrift for Kjell Havnevik, ed. Michael Ståhl (Uppsala: The Nordic Africa Institute, 2015), 182-199.

132 For instance, if a person suspects that their family wishes them harm, the person can go to the curandeiro (Ciyaawo: wayisango) and get protective n'tela (medicine). Then 
if someone uses citega against the person, the citega will not harm them, but it will return to the person who issued it and cause them to get sick. Or if a person suspects that their family has used citega against them, the person can approach their family to make amends with them and to get the antidote. One can also go directly to the curandeiro to seek treatment. There are also other forms of usawi apart from citega. For instance, "putting medicine / drugs (n'tela, pl. mitela) in the house of someone" is another form of usawi. See also Dicks, An African Worldview, 353-354.

133 Interview with Helena Baide, Lichinga, August 24, 2013.

134 Interview with Helena Baide, Lichinga, December 5, 2012.

135 Interview with Helena Baide, Lichinga, August 24, 2013.

136 Some ex-combatants are receiving their pensions in their bank accounts, but those who have not been able to open bank accounts have to go once a month to Lichinga to get their money. This does not apply to Mavago, where the ex-combatants' pensions are paid through ACLLN.

137 Interview with Helena Baide, Lichinga, August 24, 2013.

138 Early research on women and social change in Mozambique after the independence often argues that "all" women were strongly opposed to polygamy. Many of the DFs I interviewed had lived in polygamous marriages. Most of them did not speak against polygamy, though they often considered monogamous marriages less prone to social conflict.

139 Interview with Helena Baide, Lichinga, August 24, 2013.

140 Ibid.

141 Interview with Tito Brás Cassimo, Lichinga, June 19, 2014. Tito was born in Mapuje in the district of Sanga. He studied until fourth class before he joined FRELIMO. He trained in a group of 200 men in the Soviet Union in 1966. They received special training in making landmines and other explosives. In the interview, Tito first spoke of what he remembers being taught about the role of women in the struggle as well as his ideas about the relevance of this education in the daily lives of women and men these days. After this, I encouraged Helena to also participate in the conversation.

142 Ibid.

143 R. W. Connell, Masculinities (Cambridge: Polity Press, 1995), 43. 


\section{Rhythmic beauty}

HELENA: So, what did you see that you liked in the city of Beira?

FÁtIMA: Hehe. No, there isn't anything I saw, only that ... only the city, I saw.

I was in the sky. ... On the ground when we landed, I saw/experienced that here in Mahala [name of neighborhood] if one walks around . . it is beautiful/good. ${ }^{1}$

The notion of "beauty" was first introduced into our interview guide by Helena. For the first interview on childhood memories, I had initially formulated a question asking the DFs to describe how they remembered their childhood homeplaces. It was Helena who presented the additional question about the remembered "beauty" of the place. Soon the questions, "Was it a beautiful place? Can you describe what made it a beautiful/ugly place?" became routinized items of our interview guide. These questions asking about the "beauty" of place proved easy and commonsensical entry points into talking about one's affective relation with the different places of one's life trajectory but also one's relation to the more abstract space of the national landscape. For instance, as the very last question of our interview guide, we asked, "In your opinion (or "in your way of seeing/experiencing" as translated into Ciyaawo) what is the most beautiful place in 'Mozambique from Rovuma to Maputo' (the oftenused spatial construct of the wartime nationalist discourse)?" We also asked the interviewees to explain further the qualities/relations that made this place appear "beautiful" for them. These questions played two important roles: First, they provided a gentle (and often diverting) way to bring the interview to an end and focus on more pleasant thoughts and memories. Second, the questions produced interesting conversations about the desirable relation between self and environment.

The previous interview excerpt was taken from a discussion between Helena and Fátima Issa over what kind of interaction a person needs to have with a place to describe it as "beautiful." We were having this conversation while seated on small stools just inside the entrance of Fátima's house in Mavago town. It was late afternoon, and we had decided to sit there to escape Fátima's grandchildren and curious neighbors who kept gathering around. Our so far easy-going conversation moves into a slightly more heated mode when Fátima introduces the port town of Beira (the country's second-largest city in 
the central province of Sofala) as her "most beautiful place in Mozambique." Fátima tells us that she perceived Beira as beautiful when in the first years of independence she stopped over for one night on her way to Maputo. Helena, however, is not convinced. She argues that Fátima has insufficient grounds for choosing Beira. According to her, a person cannot choose a place where she has only stayed one night and which she has observed from the plane; instead, she should choose a place where she has actually lived. In Fátima's case, Helena argues, it could be Mocímboa da Praia (a small coastal town in northern Cabo Delgado; see Map 6.1b on page 183), where Fátima lived two years, or Maputo, where she also lived two years, or Lichinga (the provincial capital of Niassa). She tells Fátima that, for instance, she herself cannot speak about the beauty of Malawi: She only passed through. The delegation that she was a part of drove into Malawi by car; they slept one night and continued to drive again the next day. Despite Helena's arguments, Fátima is adamant that she has experienced enough to judge the beauty of Beira. She further insists to Helena that it was not a distanced viewing from the sky. "On the ground when we landed," as she explains, "I saw/experienced that here in this place if one walks around ... it is beautiful/good [padi pambone]."

\section{Beautiful lifestyles}

The various interview accounts suggest that the aesthetic quality of a place is not produced only through its elements, such as water, trees, rivers, mountains, and buildings (though these play a significant role), but also, importantly, through human interaction with place. The "style of life" is often identified as a defining feature of a "beautiful" place. In her account, Fátima speaks of being unable to pick one element that makes Beira beautiful; rather, through her engagement with the landscape, she perceives it as a good place. Of course, certain structures make certain lifestyles possible or, as German philosopher Gernot Böhme writes, shape "how we are bodily disposed in such and such a structured space." In an ideal situation, these elements form the "topos of the good life." ${ }^{3}$ Fátima's account shows a bodily anticipation (imagination) of a certain lifestyle, rhythmic engagement, with this specific urban space, despite her limited experience of the place itself. Helena, on the contrary, seems more critical of any simple causal relation between objective realities of spatial organization and subjective experiences. I suggest that Böhme's aesthetic concept of atmosphere is a good starting point for examining the meaning of the "beautiful" in the DFs' landscape experience.

"Atmospheres," as Böhme argues, are "characteristic manifestations of the co-presence of subject and object." "They neither belong to the object as qualities nor are they something subjective as in solely linked to the inner feelings of subjects. ${ }^{5}$ Still, as Böhme writes, they "belong to subjects in that they are sensed in bodily presence by human beings and this sensing is at the same time a bodily state of being of subjects in space." "The interview examples show how both spatial structures and the lifestyles of its inhabitants - that is, 


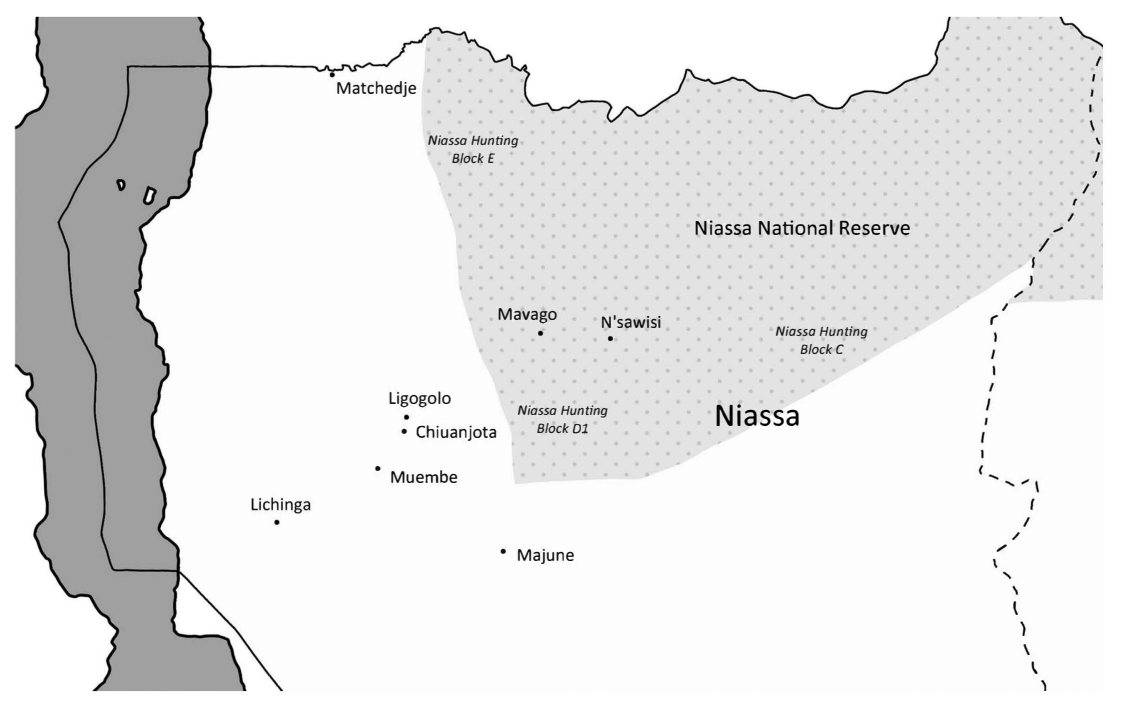

Maps 6.1a/b The multiple places of Helena's and Fátima's life narratives

Source: Maps by Noora Katto

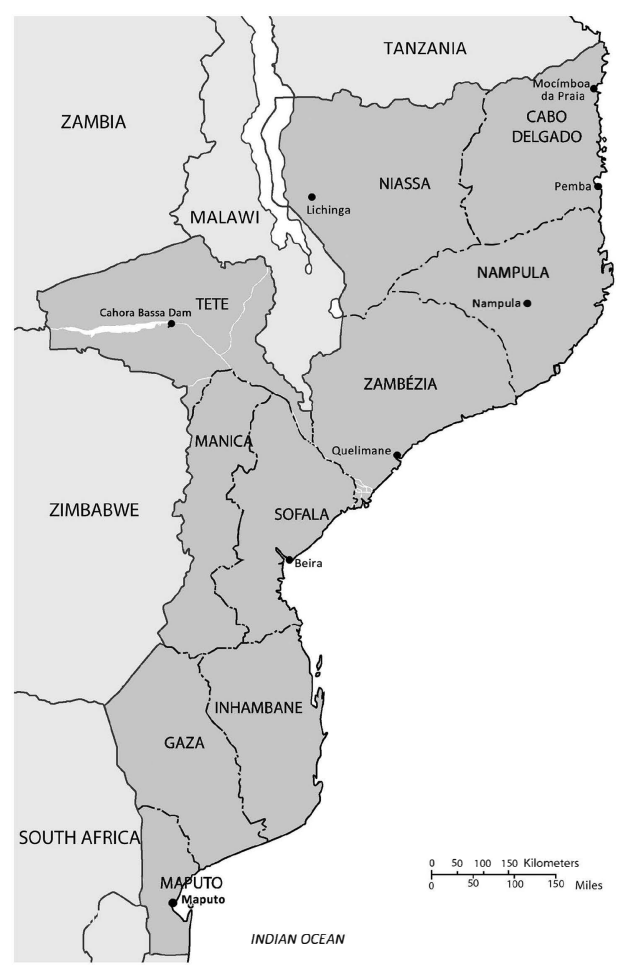


their "particular ways of living" — generate the "beauty" of a place. In Ciyaawo, the common term for beautiful, "kuralala," has the double meaning of "good." A beautiful place is also a good place. This suggests a multisensory engagement with place. Environmental philosopher Arnold Berleant uses the term "aesthetic engagement" to describe the reciprocal relationality that we have with our environment. ${ }^{7}$ His concept complements Böhme's notion of "atmosphere." In his aesthetic theory, Berleant breaks from traditional ideas of the aesthetic understood mainly through the notion of "beauty" as applied to art and nature. This idea of beauty depending on the object-subject dualism-that is, the separation of the subject from the object of appreciation-has strongly influenced Western aesthetics. ${ }^{8}$ Berleant, however, draws on an older meaning of aesthetics that denotes sense perception. ${ }^{9}$ Though " "[a] esthetic' commonly refers to the value found in appreciating art," as he explains, "in its fundamental, etymological meaning as perception by the senses, we can consider all experience fundamentally aesthetic." 10 Aesthetic engagement is a "body aesthetic"; it involves our whole body and all our senses in the active perception of the environment. ${ }^{11}$ This builds not on an idea of "pure" sense perception but recognizes how our cultural and social situatedness and personal memories inform our understanding of our sensory experiences. The notion of "beauty" is also radically reconceptualized in Berleant's aesthetic theory. Berleant argues that "when aesthetic engagement is most intense and complete, it achieves that fulfilment of value we call beauty." 12 Conceptualized in this way, "beauty" becomes a relational concept. ${ }^{13}$ "Beauty" is, of course, not the only value attributed to the body-landscape relationship. Often, the "atmosphere" of a place is fused with negative values, as I will examine later.

Returning to our guesthouse after the interview, Helena continues to express her dissatisfaction with Fátima's answer. She argues that a person cannot choose a place where she has not stayed for a few weeks, or a week at least, and claim that place to be beautiful. That person has not yet had the chance to appreciate the atmosphere (ambiente) of the place, to experience what kind of place it is to live. Then we move on to talk about the possibility that a person sees a place on TV and decides it is a beautiful place just based on those images. Helena says that even Mavago town looks beautiful on TV. But then she continues, commenting that Mavago is actually becoming beautiful because people are building here, there are many zinc-roofed houses, and there is considerable movement of people. Mavago is becoming a city. This was a commonly expressed experience of the people we interviewed in Mavago town. During harvest season, heavily loaded tobacco trucks make their way through the main road of the town. The tobacco is bought from local farmers through contract farming schemes and transported to a processing plant. ${ }^{14}$ Growing tobacco is a main source of income in the district. ${ }^{15}$ This adds movement to the otherwise quiet town and also brings in a steady flow of cash. Situated on the outskirts of the Niassa National Reserve, connected to Lichinga by a $200 \mathrm{~km}$ stretch of dirt road, and located about $100 \mathrm{~km}$ from the Tanzanian border, Mavago town is not exactly a great hub of traffic or commerce. Yet Mavago is perceived to be in 
a state of movement. "Mavago is beautiful," as a male ex-combatant Mwemedi Alifa explains:

Mmm ... I . . I I can't talk about places of visit. I will talk of my land. Ihere in my land, it is beautiful [pano pakuralala] ... here in Mavago, here ... here it's beautiful . . . because it shelters us, not to mention many things. But now where we are ... we have roads, cars pass through.... The people when they want "I will buy something from the market," even to send any child to go buy something at the market, it's not difficult. Cooking oil you will find there ... yes. The products that you farm you sell, it's not difficult. Even when I'm farming a little, I get maize, and people will come and buy right away. That is what I consider to be beautiful here, different . . from the cities. ${ }^{16}$

Many people similarly to Mwemedi expressed experiencing the town "becoming beautiful." As well as the increased movement of people and commodities, the deliberate shaping of the landscape through the construction of buildings was expressed as contributing to this positive transformation. People spoke appreciatively of the new brick houses with zinc roofs that were being built. The relatively high number of zinc-roofed houses stands out as a noticeable feature for those arriving, for instance, from Muembe. ${ }^{17}$ Among the townspeople, there was also growing anticipation of electricity infrastructure expanding to this northern part of Niassa. At the time of these interviews, a great strip of bush was being cleared close to the main road that (via Muembe) connects Mavago with the southern part of the province, and electricity poles were being erected. The district was finally going to be linked to the national grid, based on power from the Cahora Bassa dam on the Zambezi River. Moreover, having received funding from the government of South Korea, a photovoltaic solar power plant was being built on the edge of town to provide an alternative energy source. When we arrived for our final fieldwork in June 2014, Mavago had at long last gained access to electricity, and the brand new lamps of the street lights shone bright with a spectacular white clarity. Mavago was one of the last districts in Mozambique to be connected to the national grid. From 2002 until then, generators had provided energy for the public institutions and the houses of the senior administration staff. The generators had also powered the public street lights on the main road, but, as we were told, only when the president flew in with his helicopter for a visit; otherwise, there appeared to be no money for the diesel for the generators. People joked that the president should come more often to visit since that was the only time they could also admire the illuminated streets after dark. No one even mentioned the dream of having electricity in their houses. So, even now, while the public institutions and small businesses have better access to energy and the streets are lit, it is likely that most households will continue off the grid for some time to come, continuing mainly to use firewood for cooking and battery-run lanterns for lighting. 


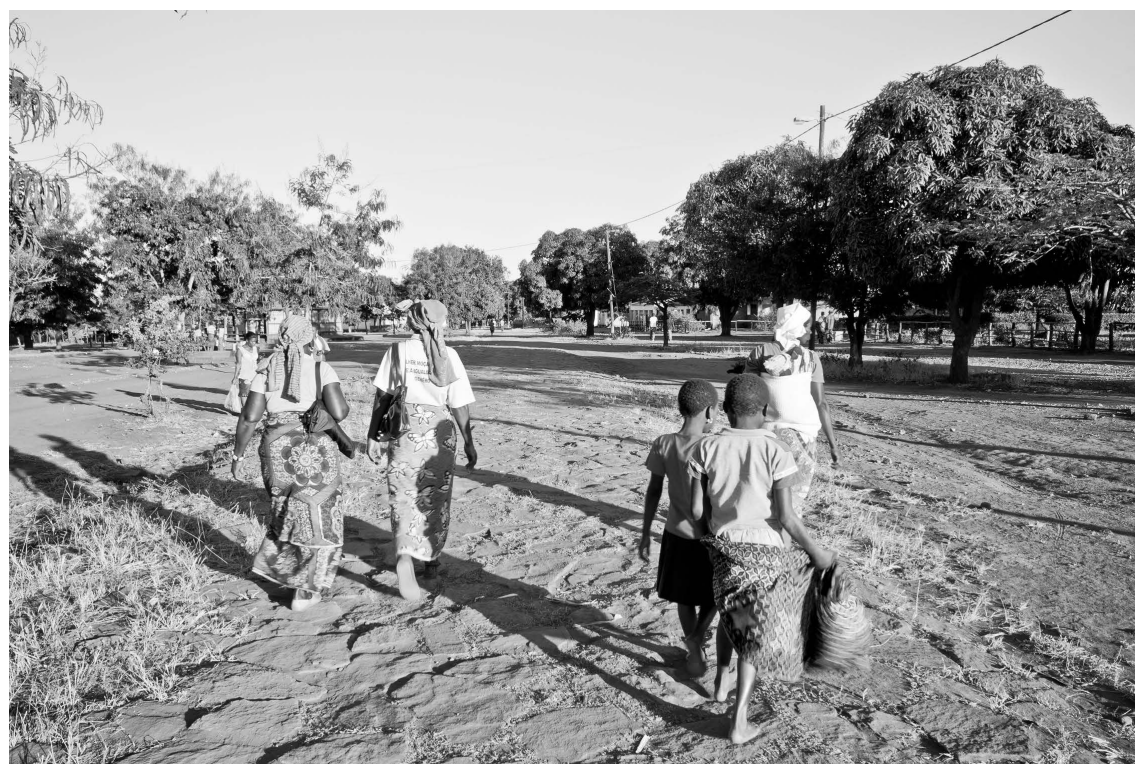

Figure 6.1a No street lights are needed in the soft light of the late afternoon sun on the main street of Mavago town; Lúcia Bala, Helena Baide and Assiato Muemedi in 2013

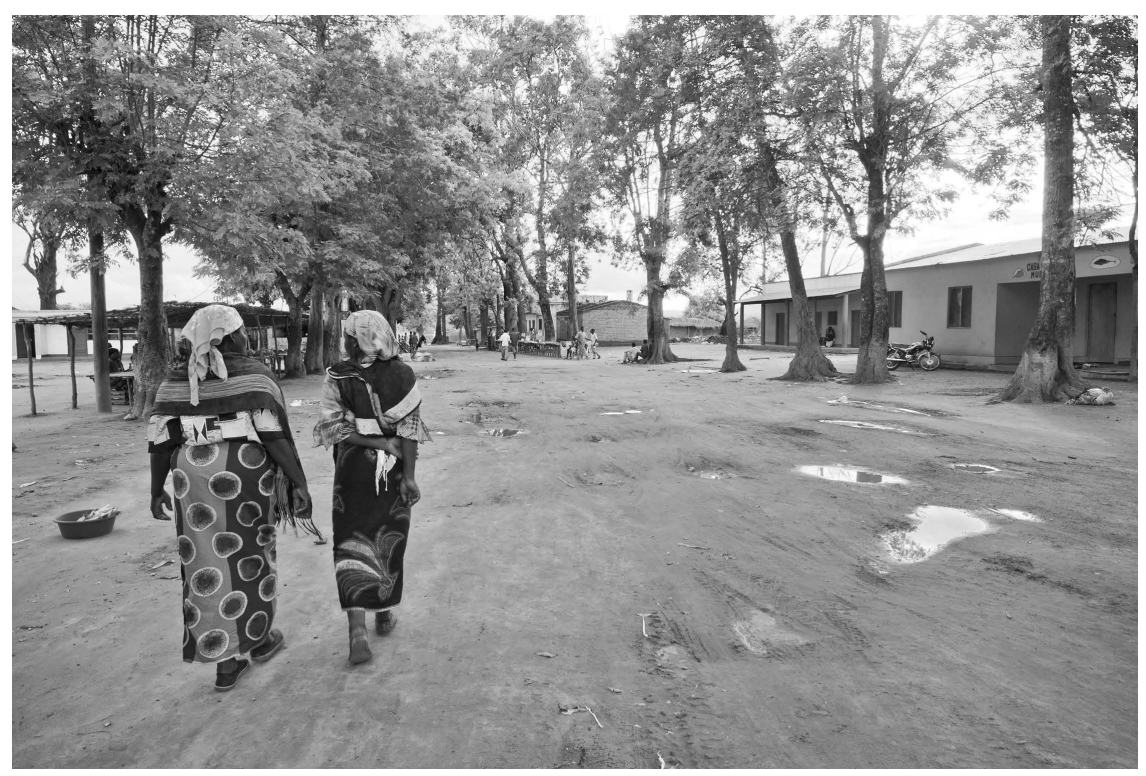

Figure 6.1b Appreciating the fresh air after the rain on the main street of Muembe town; Rosa Mustaffa and Helena Baide in 2012 
After arriving at the conclusion that Mavago is actually becoming a beautiful place, Helena changes focus to Muembe to make her point about the difference of beauty observed from the bird's view and beauty sensed through one's body. She argues that "even Muembe" looks beautiful on TV. "I saw it on TV and it looked beautiful!" she exclaims with a surprised look on her face. According to her, the perspective from which the camera person was filming created this illusion. The person was shooting from a higher ground, filming so that the whole road with its well-organized rows of houses showed, and even her mom's house and the village water pump just outside her fence looked beautiful. But when one goes to Muembe, actually goes there, Helena insists, one realizes that it is in the mato. Arguably, from my perspective, Mavago is more in the mato than Muembe. But in Helena's perception of its atmosphere, Mavago is more beautiful than Muembe. Sara Ahmed writes that the atmosphere that we experience depends on "the angle of our arrival" 18 - that is, the atmosphere is constructed through our situated engagement with a certain landscape. What is more, we bring to this exchange our histories of previous contacts. The "beautiful" Muembe shown on TV, for Helena, is a strange fictional construct, a form of aesthetic deception even. Helena's own relation and contact with the place has a different aesthetic quality. She knows what lifestyle to expect in Muembe, and it goes against her idea of the beautiful. Muembe is in the mato, she argues. In the DFs' narratives, the "bush" is often described as the opposite of a beautiful place. In Helena's account, also, "bush" evokes negative aesthetics. Still, I suggest that the notion of the beautiful landscape cannot be understood without understanding the aesthetics of the bush (which we already touched upon in Part II through the notion of haptic perception). Moreover, to understand the beautiful, we must explore the interplay between (or the intertwining of) the ugly/displeasing and the beautiful in the DFs' aesthetic experiences of their homeplaces.

\section{Aesthetics of homeplace}

HELENA: Now you since a long time ago ... the time of the war ... you wanted to go to Likole and even today you want to go there. Because during the war, even your son didn't exist-What did you like in Likole? Because in a place you have to say that I will build my house there because I liked this, this; the way of life is this, this.

LÚCIA: Because even here where I live . . I see/feel as if I were in the bush, like there where I used to live [during the war]. Lifting my eyes, I see trees. Now there in Likole ... sometimes I think that EIH [expression of admiration] [continues in a lower voice], I lived/stayed in the bush, again to come and throw myself in the bush.... Here, if I had money ... my house [I would build] in Likole. Because [continues in a high pitch] in Likole, they call it the second city. Because there it is in the city. LIFT your eyes like this, all that you will see clean/clear. And my heart goes there, to build my house it has to be in Likole, $\mathrm{mmm}^{19}$ 
Helena's question to Lúcia is informed by our previous conversations with her. Likole, she claims, was on her mind already during the war. It has been her long-term desire to make Likole her home. As she tells us, she used to imagine that if she were to have money after the war, she would "build a good house" and open her machamba in Likole. At present, Likole is a large village located in the busy intersection of the road leading west to Metangula, the administrative center of the Lago district by the shore of Lake Niassa, and the road leading north to Malulu and further to Matchedje (or II Congresso) by the Tanzanian border (see Map 6.2 on the following page). Lúcia likens her experience of Likole to that of being "in the city," whereas in her current homeplace, Mawumbika II, she describes feeling "as if I were in the bush." Mawumbika II is a small village located about midway between Lichinga and Matchedje, about $50 \mathrm{~km}$ from Malulu, the district's administrative center. After Malulu, or Unango Mountain to be more precise, the tar road turns into a dirt road, the chapa ride becomes bumpier, and the travel speed slows down. Mawumbika II can be described as a satellite settlement of Macaloge, the biggest village on this stretch of road between Malulu and Matchedje. In colonial times, Macaloge was an important Portuguese army post. The Macaloge area marks the border between the very sparsely populated (average density of about 0.5 people/ $\mathrm{km}^{2}$ ) northern part of the district and the more densely populated southern part (average density of about 4 people $/ \mathrm{km}^{2}$ ) where most of the district infrastructure is located. ${ }^{20}$ Macaloge hosts a secondary boarding school. The school grounds bustle with students, though otherwise the town sticks to a sleepy pace. The stretch of road between Macaloge and Malulu is quiet in traffic, but the flow and circulation of chapas intensifies on the Malulu-Lichinga section. Still, Macaloge is much better connected to Lichinga than Matchedje where one can expect one southbound chapa per day (or two days). The villages in the area including Mawumbika II are concentrated around the main north-south road and are surrounded by dense woodland with mountains framing one's visual horizon (see Figure 6.2a on page 195).

Map 6.2 shows the geography of Lúcia's movement during her life (as narrated in the interviews). Born close to Mount Unango, during the war, she served mainly at Base Ngungunyane on the western military front. When the war ended, as she describes, she continued to work an additional year at Base Ngungunyane before she was transferred to Metangula. Still part of the army structure, she worked there as a cook and as military police controlling the movement of the people. After a year, she was transferred to N'sawisi (in Mavago) where she worked at a state farm for three years. Here, her life was governed both by the monotonous patterns of military discipline and the cyclical rhythms of the machamba. She describes the rhythmicity of her life:

Now we of the detachment, at dawn when they blew the whistle and selected us to go there to that machamba ... planting the maize, and weeding that maize. After finishing the work in the machamba, it was time to return to one's place. ${ }^{21}$ 


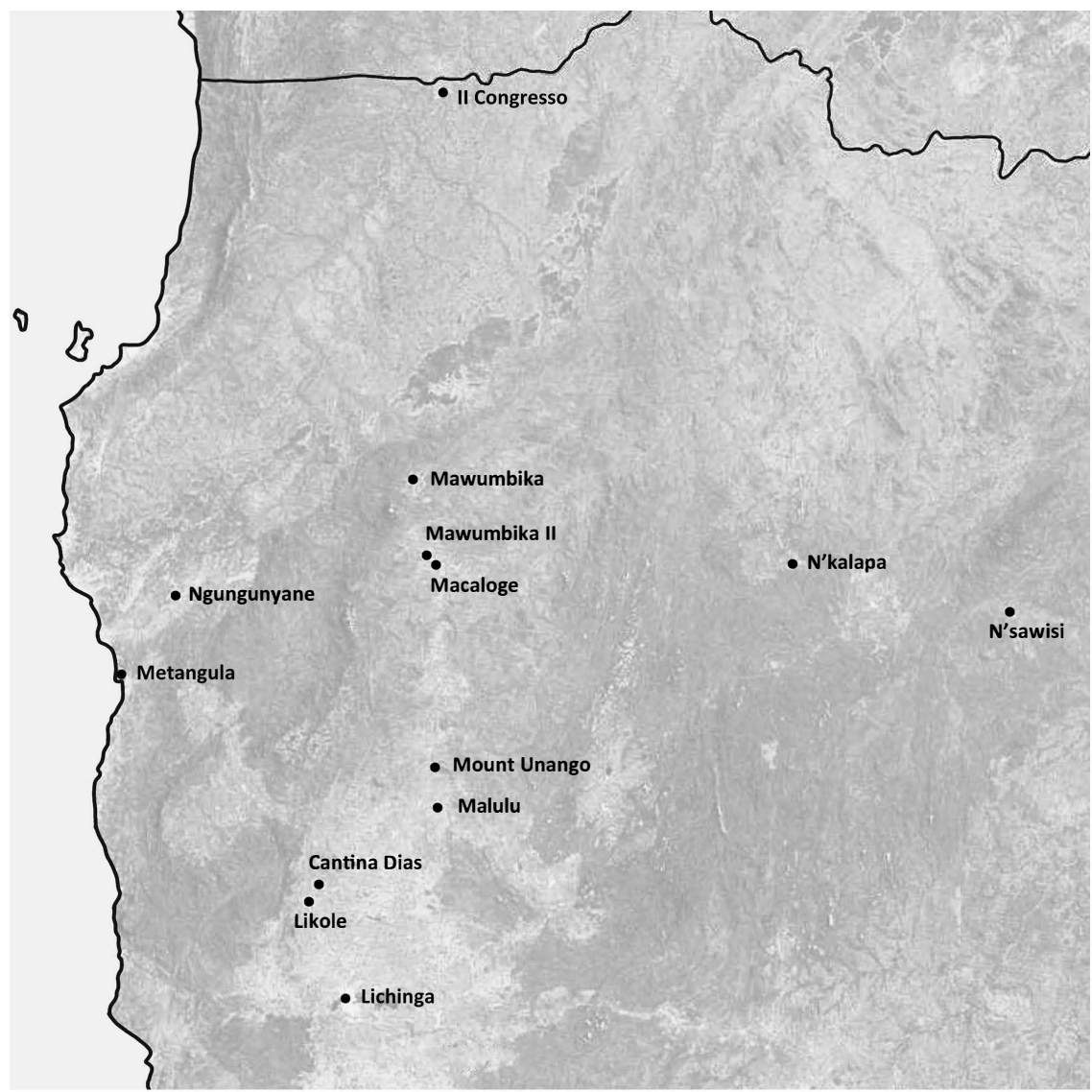

Map 6.2 Lúcia's homeplaces after the war

Source: Map by Noora Katto

Similarly to the other DFs I interviewed, she remembers her time in the army after the liberation war fondly. The ex-combatants' narratives of the first years of independence are filled with pleasant memories. This was a time of great optimism for them. Guided by a Marxist-Leninist ideology, Frelimo was taking big steps to transform the national economy along socialist lines and create a "new society."

Industrialization was hailed as the main means of combating "undevelopment." ${ }^{22}$ Yet as Frelimo took over an economy that was highly dependent on agricultural imports, it first needed to prioritize food production and the transformation of the rural areas. ${ }^{23}$ Niassa, in particular, became targeted through the reeducation program, operating from 1974 to the late 1980s, ${ }^{24}$ which collected the "unproductive" (os improdutivos; e.g., alleged criminals, traitors, army 
deserters, prostitutes; unemployed and otherwise economically or socially marginalized people; vagrants; unmarried women) off the streets of Maputo (and other urban areas) and sent them to the labor camps in the "bush." 25 Anyone who failed to produce an identity card, work documents, or document of residence was at risk of being relocated. The majority of the reeducation camps established by the government were located in Niassa. ${ }^{26}$ As Beatriz Assima, who worked at a camp in N'sawisi "controlling" the people explains, ${ }^{27}$ according to Samora Machel, the townspeople had learned bad ways of living under Portuguese colonialism, and they had to be retaught how to make an honest living. Moreover, as she remembers Samora explaining, Maputo was overcrowded with "people on top of people," while in Niassa, "there is a lot of bush, there is no one." 28 Thus it was better to "evacuate" these people from Maputo and take them to Niassa. ${ }^{29}$ Through the political education of collectivism and through instilling the habits of the "new man" on their bodies, the reeducation program was to transform these marginalized people and make them productive members of the new society. ${ }^{30}$ This was a violent process that required the destruction of the old structure and social relations. The "new man" had to embrace socialist modernity and distance themself from the practices and social relations of traditional society; ${ }^{31}$ for instance, Frelimo opposed religious practices, initiation rites, lobolo, and traditional leaders. Embedded in this process was the reshaping of the body-landscape relationship.

A great deal of Frelimo's economic policies were geared toward modernizing the countryside. ${ }^{32}$ Niassa was in the forefront ("uma frente prioritária na eliminação do subdesenvolvimento") ${ }^{33}$ as the least populated province in Mozambique. Sérgio Vieira, the governor of Niassa (1983-1984), argued that Niassa, with a territory that counts for 16.5 percent of Mozambique's total land mass and with a population of only 545,000 inhabitants, needed more people to be able to exploit its vast resources and increase its production. ${ }^{34}$ During the first years of independence, Frelimo promoted aldeias comunais (communal villages), state farms, and agricultural cooperatives. In 1983, Frelimo launched Operação Produção (Operation Production), which in official discourse was framed as a campaign to promote food production; though, as Benedito Machava argues, in reality, it was a violent cleanup campaign that criminalized unemployment. ${ }^{35}$ During the initial fifteen-day phase, the "excess" townspeople without jobs could sign up for voluntary relocation to their chosen location in the rural areas. ${ }^{36}$ Yet the next phase already involved the forced mass removal and resettlement of these "unproductive elements" of the population. ${ }^{37}$

In political discourse, the communal villages-where also the "unproductive elements" were sent-were hailed as "the future cities." 38 Their idea was to gather the dispersed family farmers together into bigger communities. These villages were organized around cooperative farming and consumer cooperatives through which villagers could access otherwise unavailable basic consumer goods, such as soap, capulanas, sugar, and salt. The purpose of communal villages was, moreover, to provide these concentrated populations with social services, 
such as schools and health centers. One of these villages was Unango, whichas people in Malulu (the administrative center of the district of Sanga in the proximity of Unango) told me-was a great favorite of Samora Machel. ${ }^{39}$ The communal village of Unango was originally founded by 500 ex-inmates who had been reeducated and amnestied by the president. ${ }^{40}$ Later, their numbers were augmented by "the non-productive elements" sent from Maputo. ${ }^{41}$ An elder called Omadi Dawadi, whom I interviewed in Malulu, spoke of the city that had existed at the time: houses had filled the landscape between Malulu and Mount Unango, an area that is now void of people, and agricultural and livestock farming had been thriving. This was largely due to a massive project in large-scale industrial agriculture, the Empresa 400 Mil Hectares (400 Thousand Hectare Enterprise) that Samora Machel had launched in the early 1980s. ${ }^{42}$ According to Ce-Omadi, the city of Unango was, however, destroyed by the "war of Dhlakama."43

Several female and male ex-combatants spoke of working on collective state farms during this time. For some, this involved learning new styles of engagement with the landscape, such as new ways of cultivating the land using modern technology. Rosa Salimu, for instance, proudly remembers having a job operating a tractor to plow the fields at a state farm close to Lichinga. ${ }^{44}$ These early years of communism are often remembered with nostalgia for the politics and way of life of the time. The idea and practice of collectivism was familiar to the ex-combatants who had received their crash course during the war. ${ }^{45}$ My interviewees make no mention of the difficulties that the reeducation camps and the communal farms are reported to have had, such as low production levels and the lack of basic necessities (food, clothes, blankets, and medicine) that led to a great deal of suffering and even loss of lives. ${ }^{46}$ Instead, Lúcia, for instance, speaks of how she enjoyed this time since "all the people were working to support each other not to suffer." ${ }^{47}$ One must, of course, also take into account that the ex-combatants working in the military had more privileges in comparison to many others during this era. Scholars of Mozambican history have convincingly argued that among the general population, Frelimo's economic policies contributed to a sense of alienation between state and citizen that also helped RENAMO gain support among the rural population during the civil war. ${ }^{48}$

At the end of three years working at the collective farm, Lúcia was demobilized and told to "go to the village of her mother's" (maternal kin). An army vehicle dropped her off in Mawumbika, a village north of Macaloge, where her parents had settled after the war. She remembers that she was given 300 meticais, which was a substantial amount of money at that time in rural Mozambique. This helped her during her first years after demobilization. At the time, she was unmarried, so she lived with her parents. For her, this move marks the beginning of a new period in her life, and she talks about finding it difficult to adapt to civilian life in the village. This is how she describes her less than pleasant encounter with the Mawumbika landscape: 
HELENA: Now how did you see/experience/feel when you arrived in this place? Did you like or did you not like?

LÚCIA: When I arrived in this place here ... aah, I didn't like. . . Aah, looking here, here: [only] bush шишишии [admiring its great size]. To do like this [looking around]: bush everywhere, $\underline{\mathrm{ih}}$.

HELENA: Still.

LÚCIA: [Overlapping speech] My goodness. . still to continue in the same ... IF it were there [in the city], looking around, everything would be clean/ clear [ngwelengwende]. . . . Now here until when this? ... That was making me unhappy. ${ }^{49}$

As Lúcia describes, everywhere where she looks, she only sees n'tinji (bush). Her words suggest that this was for her a "perceptual insult," to use Berleant's term, ${ }^{50}$ an aesthetically offensive experience. Her encounter with the landscape offered no pleasure; instead, she talks about becoming sad. The affective relation between her body and the landscape is imbricated by negative feelings. Moreover, her sadness intensifies when she compares her experience to the imagined happiness, pleasure, freedom of those merged within a "clean" landscape that has no obstacles. In Ciyaawo, this type of experience is often described through the ideophone ngwelengwende.

Negative or positive aesthetic values, Berleant argues, "do not arise from inherent features of the landscape itself." ${ }^{51}$ Moreover, as he explains, "aesthetic is a dimension" of the environment. ${ }^{52}$ Our aesthetic values are shaped by cultural frames and through our sensuous engagement with landscape. The nationalist "promises" of socioeconomic modernization (previously framed by a socialist ideology, these days by neoliberal capitalism) have especially framed ex-combatants' ideas and experiences of the "bush." Frelimo's discourse of socialist modernization with its utopian visions of bush turned into cities introduced new normative aesthetic values into the body-landscape relationship. Beautiful as an aesthetic value became linked to ideas of socialist modernity and its accompanying lifestyles. Still, these cultural and societal frames alone do not determine the aesthetic value of landscape. People have different personal experiences of landscape, which intimately inform their aesthetic experience. Landscapes are valued based on past experiences of previous sensory engagement with the environment; one's life rhythms always leave sensory impressions on the body. As Lúcia describes in the excerpt on page 187, "Sometimes I think that EIH, I lived/stayed in the bush, again to come and throw myself in the bush." The beginning of civilian life marked for her a "return to the bush." Especially, for ex-combatants, the aesthetic experience of the "bush" is deeply informed by their memories of the often violent tactility of their lived relationship with the landscape during the many years of war.

The aesthetics of the "bush" and the aesthetics of home are negotiated in relation to each other. While Lúcia speaks of the negative aesthetics of Mawumbika, she speaks favorably of N'sawisi. At the time of the interview, I found this difficult to understand. From my perspective, the landscape of N'sawisi in 
Mavago and the landscape of Mawumbika equally fit the category of "bush" (and both were commonly referred to as being "in the bush"). This means that they are both merged within woodland, physically distant from Lichinga, and difficult to reach by local transport. So I asked Lúcia to expand a bit on the differences between the two places:

JONNA: Aah, mas em N'sawisi também é mato lá.

HELENA: Akuti nambo ku-N'sawisi nombe nako kwitinji kwekula.

LÚCIA: Ku-N'sawsi kwitinji, nambo ngati . . twawonegana kuti leelo jino jumamosi ni twajaga kwenda-jenda kumuri kwa acinawandu-ko.

\section{$(\ldots)$}

JONNA: Aah, mas em Mawumbika foi pior? Hehe.

HELENA joins me in laughter and laughs lightly as she speaks: Akuti kuMawumbika ni kwapundile n'nope? Hehehe.

LÚCIA also laughing: Hehe, mati ngadi kwa kwendajenda kwele. Akuti kwendajenda NGADI [JONNA: hehe].

HELENA: Não tinha lugar de PASSEAR. [Laughs as she speaks:] Amanheceu, aí mesmo. No fimde-semana, AÍ mesmo.

LÚCIA: Kupaseyari kutenda kumigunda kwele.
JONNA: Aah, but in N'sawisi it is also bush there.

HELENA: She said but there in N'sawisi it is also in the bush.

LÚCIA: N'sawisi is in the bush, but as ... we would meet, say that today it is Saturday, and we would go for a walk to the village of those people.

JONNA: Aah, but in Mawumbika it was worse? Hehe.

HELENA joins me in laughter and laughs lightly as she speaks: She said that in Mawumbika it was worse? Hehehe.

LÚCIA also laughing: Hehe, because there there is no place to go. There is NOWHERE to go for a stroll [JONNA: hehe].

HELENA: There was no place to $\underline{\mathrm{GO}}$ FOR A WALK. [Laughs as she speaks:] In the morning, right there. In the weekend, right THERE.

LÚCIA: To go for a walk was to go to the machamba there. ${ }^{53}$

Here the aesthetic experience of landscape is connected again to the lifestyle that the place enables. As Lúcia explains, though N'sawisi is in the bush, the military base was located next to a big village, and on Saturdays, the DFs would entertain themselves and go for a leisurely stroll there. We must bear in mind that N'sawisi was a site for a big communal village, a "future city" as it was dubbed in Frelimo discourse. Mawumbika, on the other hand, lacked "a place to go," with the only possible destination being the machambas. The sphere of one's weekly movement and social engagement was more restricted there. For two years, Lúcia was stuck living in Mawumbika. Then her mother's younger sister moved south to Cantina Dias (close to Likole), and Lúcia decided to follow her. As she describes, she wanted out of the "bush." 
HELENA: M'mwe kucenga korope-

ko digongo dya ngayiraka kutamila kwitinji?

LÚCIA: [Overlapping

Kucenga kore-ko. Wune ndemi mwitinji, mpaka dez anos na luta. RAno roni kwira kutama kwitinji. Eih ... ngawa yele-

[Helena, Lúcia, and Jonna start laughing.]

HELENA still laughing: Ah nada. [JONNA: Hehe.] Entendeu nem? Hehe.

JONNA joins Helena in laughter: Hehe, sim, sim. . . . Mas esse, esse novo lugar-Cantina? [HELENA: Cantina Dias.] Cantina Dias. Gostou de viver lá?

HELENA: [Overlapping speech] Nambo kwele pa mwayice kwele kun'nonyele?

LÚCIA: [Overlapping speech] kwele wune pa nayice kwele-ko kulolela kuti n'nyi, aah sim.... Apa bola. [Helena starts laughing again.] Apa, bola pa. Kuti n'nyi kutawuni ngukuwona. Kuti n'nyi kwekula ku-Enjenyarya. Aah, bola apano.
HELENA: You changed all these places because you didn't want to live in the bush?

LÚCIA: [Overlapping speech] Changing all those places. I lived in the bush, up to ten years in the war. NOW again to come and live in the bush. Eih ... that won't do-

[Helena, Lúcia, and Jonna start laughing.]

HELENA still laughing: Ah no. [JONNA: Hehe.] You understood, isn't it? Hehe.

JONNA joins Helena in laughter: Hehe, yes, yes. . . But this, this new place-Cantina? [HELENA: Cantina Dias.] Cantina Dias. Did you like living there?

HELENA: [Overlapping speech] But there, when you arrived there, did you like?

LÚCIA: [Overlapping speech] there I, when I arrived there, I looked around like this, aah yes.... Here it is preferable. [Helena starts laughing again.] Here it is preferable. To do like this [looks around], I see the town. To do like this [looks around], there is the Engenharia [army barracks close to Lichinga]. Aah, it is preferable here. ${ }^{54}$

Cantina Dias incites Lúcia's "geographical imagination." 55 It engages her to imagine a broader horizon of reach and a different rhythmicity of life. Cantina Dias is located close to Likole and the busy Lichinga-Metangula road, which is a more densely populated area. Lúcia describes how from there she could see the "city" and the "Enjenyaria" (Frelimo's army barracks just outside of Lichinga). This points to her sense of feeling part of an urban landscape and her sense of closeness to the state apparatus. Lúcia lived many years in Cantina Dias, and she describes these years as happy. She met her husband and started a family while living there. And though the RENAMO war was going on at the time, she speaks very little about those difficult experiences, only mentioning that, together with her family, she would hide in the bush when the RENAMO soldiers came too close to the village. 


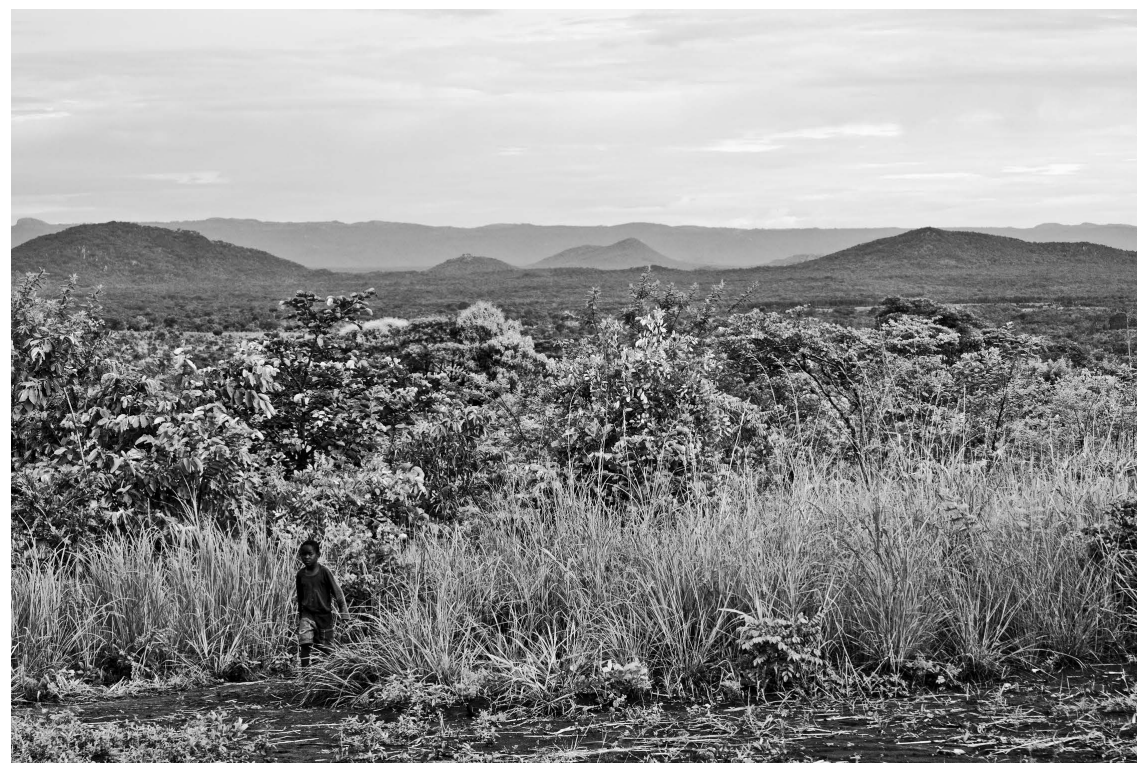

Figure 6.2a Undesirable landscape in Macaloge 2013

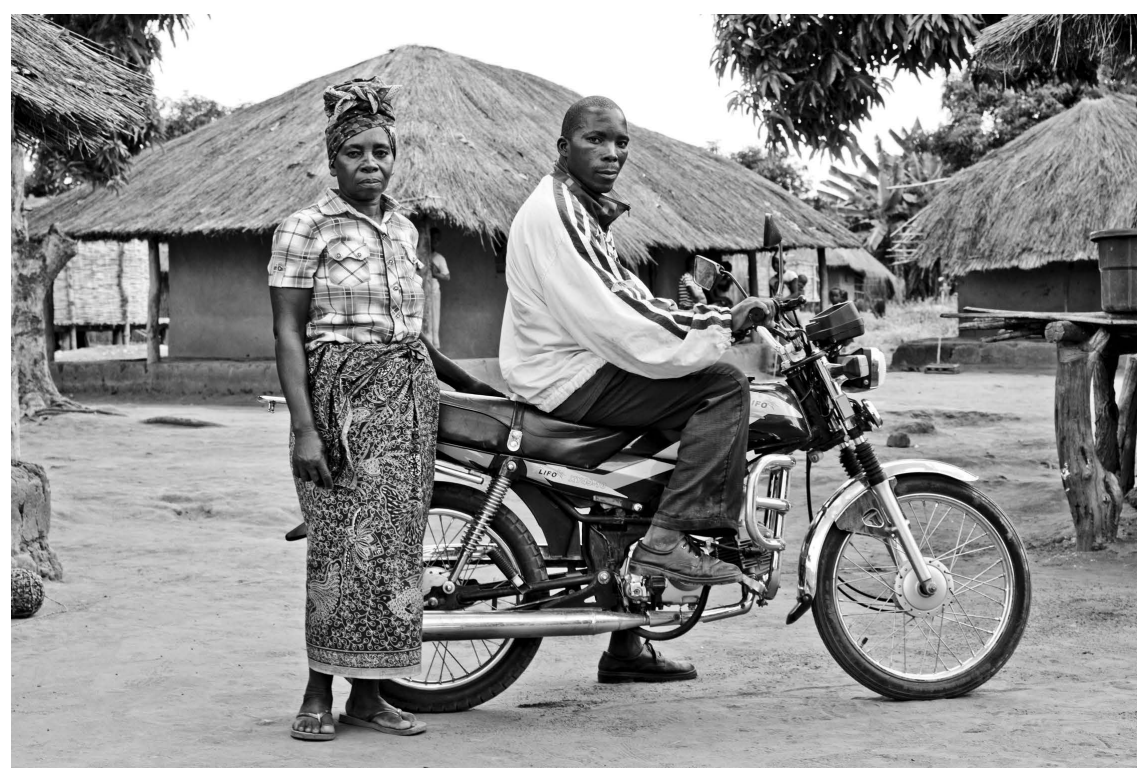

Figure 6.2b Desirable rhythms of homeplace; Lúcia Abdala with her son, Sanga, 2014 
During the war of RENAMO, as Lúcia describes, many people moved away from Mawumbika and sought refuge in the proximity of Macaloge, where government troops were stationed. This is how Mawumbika II was established. Lúcia's parents were among those who relocated. When Lúcia's mother died, her dad was left on his own, and as Lúcia was experiencing some social problems (she never elaborated on these issues) in Cantina Dias at the time, she thought better to move to live with her family. Her husband agreed, as he wanted to have hortas (Ciyaawo: ditimbe, pl. matimbe; wet lowland fields or gardens by rivers that require a considerable amount of work but produce vegetables of all sorts during the dry season), and in Mawumbika II, there were good opportunities for this. Now they have lived eight years in Mawumbika II. Together with her husband, her family rotates between working on their machamba (Ciyaawo: ngunda, pl. migunda) in the highland (Ciyaawo: lutando) and their horta in the lowland (Ciyaawo: kwi-wanda). Having both horta and machamba keeps them very busy, and they have little idle time. Farming the horta is considered "man's work," as it requires constant hoeing of the soil. The different crops have different alternating cycles that dictate the rhythms of their core activities: hoeing, sowing, weeding, and harvesting. They sell part of their produce-for instance, collard greens, potatoes, cabbage, tomatoes, carrots, onions from the horta, and some maize from their machamba, if they produce a lot that year-to traders who come to Macaloge from Lichinga. Most of the maize and beans from the machamba they keep for themselves to eat during the rainy season. Lúcia and her husband are doing relatively well and have a regular monetary income. They have not managed to build a casa melhorada, but her husband has a motorbike. The motorbike makes going to the machamba and horta easier and increases their mobility. Lúcia does not drive the mota herself, but when she needs to, she gets a lift from her husband or son. The Chinese manufactured motorbikes are becoming more and more common across northern Niassa. They are what James Ferguson calls "signs and symbols of modernity." 56 When I was taking photographs of Lúcia and asked her which kind of picture she wanted to have for herself, she requested that I take one of her posing with her son and their motorbike. ${ }^{57}$ In the DFs' narratives, aesthetic value is often fused with utilitarian, moral, and social values.$^{58}$ For Lúcia, the motorbike is a sign of beauty; it embodies the promise of a more desirable lifestyle.

The "beauty" of landscape is, importantly, also construed through its social rhythms. People and social relationships are integral to the fabric of place. Berleant fittingly writes that aesthetic experience of landscape "involve[s] an appreciation and judgement of both the environment and its inhabitants." ${ }^{9}$ In the interview accounts, the experience of social peace and harmony is a very important aspect of a beautiful landscape. In the DFs' narratives, one's relations with one's neighbors are an especially important factor determining the livability of a certain place. This, I suggest, is part of the aesthetic quality of place. Although Lúcia dislikes the location of her village, she says that she likes her home because she lives peacefully with her neighbors. She has no arguments with anyone. She is away from home a lot working at the horta, but no one 
seems to think badly of her. She can come and go as she pleases. Her neighbors let her live in peace. For my interviewees, places have little meaning outside human relations. A place that goes uninhabited eventually turns into bush. When I ask Lúcia about her childhood homeplace in Unango, she describes not having any affective relationship to that place any longer. She left it a long time ago. Her village, which was situated away from the road, no longer exists, since these days everyone prefers to live next to the road. This is a consequence of many different processes: Portuguese wartime aldeamento programs, Frelimo's communal village plans after independence, the turmoil and dislocation caused by civil war, and these days, the better access to markets and government institutions and infrastructure that living next to the roads enables. When Helena asks Lúcia if "there is not anything she covets even a little" in that place ("Rano kwele ngankukulajila anta panandi?”), Lúcia argues no, since her "family elders have already died." ${ }^{60}$ In Mawumbika II, she lives close to her father, three younger siblings, husband, and four of their children; one of her sons lives in Likole; three of her grandchildren live in her house with her. She speaks of her husband as a man with a good heart ("ntima wawo wambone") who treats her and her children well. "We live peacefully" ("tukulama ni wutendele"), she says, describing their life together. In her accounts, Lúcia expresses social connectedness to the cohabitants of her place of residence. Still, despite the in many ways appeasing social quality of Mawumbika II, the dominating aesthetic experience of the place remains negative.

For Lúcia, Mawumbika and Mawumbika II generate similar aesthetically negative experiences. She did not move to either place because of her own desire. These days, her husband's economic activity in Mawumbika II ties her to the place. He is making a good living for them, and she has no means to move to Likole on her own. She has not yet started receiving her pension, though she started the process a long time ago already. As expressed in many of the narratives, the veteran's pension is an important means for DFs to gain more independence and increase their mobility. Lúcia's strong desire is to build a house in Likole and thus establish her home there as soon as she starts receiving her money. As she throughout the interviews expresses, her "heart goes to Likole." In the conversation that follows, she further clarifies her reasons:

HELENA: Rano pele pa ndawi pakutandila pele m'mwe kun'nonyela jele aldeia kuti nambo apano ni peralale pakunonyela? Digongo jadiji muri WEKULUNGWA ou kwamba kuparaka-pe bari kun'nonyela-pe?

LÚCIA: Ya patite katame kakwe yikunonyela.

HELENA: Aquela maneira que sentaram estou a gostar muito
HELENA: Now like this, at the time, did you like that village, to say, but here it is beautiful, I like it here? Because it was a BIG village. Or, you just wanted, just liked it there?

LÚCIA: The way of life/being I liked.

HELENA: That way of sitting/ dwelling I liked a lot. 
JONNA: E aquela maneira? Pode descrever um pouco? Essa maneira como que é? Hehe.

HELENA: Katame kakwe kantundu-ci ka kakumpulula m'mwe?

LÚCIA: Pele-po ngutenda n'nyi ndi [looks around]—ndi n'nyi iyi, kulolela kuti [continues in a highpitched voice]: yele mpaka ku-sidade woneka! Nambo mpaka ku-Kantina Dias kukuwoneka! Awu mpaka ku-Mbemba. RANO ndi nyimi kuti yele: Ihyah apano-pano wune kwimika nyumba jangu, mpaka pawe cenene. Ni wanace wangu iyo nanryene iyi, mpaka pawe cenene. Wanace kung'anda kwa wutendele ... eeh. NGAtenda. Kwimuka N'NYIN'NYI mwitinji njunga. Yele ni ya ngangukuraka akunokuno akuno.
JONNA: And that way? Can you describe a bit? This way, how is it? Hehe.

HELENA: What way of life was it that attracted you there?

LÚCIA: There, I do like this [looks around]—when I am like this, I look like this [continues in a high-pitched voice]: One can even see the city! But even up to Cantina Dias you can see! Like this even up to Mbemba. NOW when I stand like this, when I do like this: Yeah, here if I will build my house, I could live well here. With my children like this, I myself like this, one could live well here. The children playing peacefully ... yes. NOT happening. Waking up LIKE THIS thrown into the bush. This is what I don't want here, mmm. ${ }^{61}$

Lúcia is attracted to the way and pattern of living that she observes in the Likole landscape and imagines how her personal lifestyle could be positively transformed by dwelling in such a place. ${ }^{62}$ In Lúcia's narratives, aesthetic sensibility is deeply intertwined with her experience of spatial attachment/detachment. For Lúcia, as well as the other DFs, aesthetic disappointment is infused with a strong sense of social injustice. The aesthetic and the moral are often deeply intertwined values. ${ }^{63}$ As Lúcia's story shows (and as I argued in Part II), the mato is strongly linked to the ex-combatants' memories of the war against Portuguese colonialism and the disappointment of the unkempt promises of liberation - that is, the social and ethical ideals of the nationalist movement. But the DFs' stories also refer to other more positive ideas of the mato. During times of troubles and war, the mato has often been a place of escape and rebellion. For instance, young girls sometimes rebelled against the marriage institution by escaping into the bush. Also, during the liberation struggle, the bush was the space of revolution and the center of nationalist politics. It was after the war that the political center shifted from the bush to the capital city. ${ }^{64}$ Still, even after independence, the ex-combatants continued to be identified through their connection to the bush. It became an important part of their self-identity, a means to differentiate themselves from the rest of the population. For some DFs, their relation with the bush is a positive bond to be remembered. Maria, for instance, draws on this bond and turns it into a form of positive personal identification. As 
she says, "I have love for my country because I liberated! All of this, it was I who brought ... from the bush to here." ${ }^{65}$ Considering the combatant-bush relationship as a positive bond is more common for the nationalist elite than the marginalized ex-combatant population in Niassa. The accounts of ex-combatants in Maputo suggest that the "bush" is no longer an embodied landscape for them but that their bodily relation with the bush has been discontinued. For many ex-combatants in Niassa, their continued experience of living in a hostile environment does not allow them to forget the bush. The haptic memories of it persist and intermingle with the negative aesthetics of their current lived environment. These ex-combatants emphasize the negative and even violent effect of their continued bond with the mato. After the war, ex-combatants were commonly labeled as "those who went to the bush." Though it used to suggest the positive value of their personal sacrifice (which led to national liberation), these days, it often appears to carry negative connotations. The ex-combatants' bond with the bush is experienced as something of which to be ashamed. ${ }^{66}$ Many ex-combatants in Niassa speak of how their military engagement in the "bush" prevented them from going to school. They speak apologetically of their lack of education. They now belong to the less civilized ("illiterate") segment of the population, out of sync with the socioeconomic rhythm of the times. After all, the national development discourse leads one to believe that education is the key to economic success and a modern, more urbanized lifestyle. ${ }^{67}$ The interviews point to a connection between bodily well-being and the experience of a beautiful, fulfilling landscape. I refer to this as "peaceful dwelling." Importantly, it is also closely tied to a sense of socio-spatial belonging. This resonates with Berleant's argument that "[w]ithout a somatic attachment to place, we stand homeless, regardless of our domicile." 68 Still, the overwhelming experience of many DFs, like Lúcia, is that they have not yet left the mato, and thus in some way, they have not reached home. But, as we will continue to explore, positive and negative aesthetics are not opposing poles on a scale; their relationship is far more complex. Moreover, personal belonging is always negotiated in relation to other individual and collective rhythms, which together constitute the polyrhythmic landscape of "Mozambique."

\section{Polyrhythmia, eurhythmia, and arrhythmia}

HELENA: The last question of today: These days ... do you see/experience here in Mozambique that it is a good country for people to live in?

ROSA: Mm, it is very good. Because we are leaving/going from here. . . Today where do I want to go? I am going to town ... to converse there, to go walk about. We leave from here, travel by car: wuuuu, travel to town. And you will go, walk around there, looking for what you want, then you again return here, yes. This country is clean [there is no turmoil, no disarray]. If it weren't for Mr. Dhlakama disturbing, we would consider this country clean [cilaambo cino cicapiceje] ... yes. It is that peace that we want ... yes. ${ }^{69}$ 
Landscape is best conceptualized as a polyrhythmic assemblage (or entanglement) of diverse rhythms within which a subject is embedded through their individual life rhythm. Here, the physical (or "natural”), social, and political cannot be separated from each other, but their different rhythms are deeply intertwined. The very materiality of landscape emerges within their interplay. The cyclical rhythms of the "natural" world (e.g., days, seasons) entangle with our linear rhythms of human action, and while analytically we can separate between cyclical and linear repetition, in the lifeworld, as Lefebvre points out, they are fully enmeshed. ${ }^{70}$ Eurhythmic landscape, moreover, is the experience of the harmonious coexistence of these various rhythms at a given moment. ${ }^{71}$ The predominating experience of Mozambique expressed in the interviews is of a "good place to live." This was explained first through the experience of peace. As Rosa Chalamanda expresses, "this country is clean." The violent tactility of the relationship between self and environment that existed during the war no longer prevails. Lefebvre argues that sensory experiences are part of rhythms and make rhythms recognizable. ${ }^{72}$ Peacetime brought a profound change to the soundscape; one can no longer hear the noise of bombers, helicopters, or shooting. Peace also reshaped one's landscape experience through the alteration of smells and tastes. The smell of blood or ammunition no longer infiltrate one's senses, and food once again has taste. One's haptic experience of the landscape has also changed from aimless running in the bush to dwelling peacefully in landscape. As Rosa Saide explains,

Every person is living, even going to the machamba ... there you are working, you are moving well, there isn't anything that is disturbing you. Even arriving home, you encounter a bit of food that you eat. You don't hear anything: [you don't hear] that thing, that thing, that thing. It doesn't compare with long time ago. ${ }^{73}$

The accounts of both women attest to the changed rhythmicity of one's engagement with landscape in peacetime and the freedom of one's everyday movement. Still, Rosa Chalamanda's account expresses worry that Mr. Dhlakama (the leader of the opposition party Renamo) will destroy the "cleanness" of the country by bringing an end to political peace. A regression into civil war would hinder the future development of the country and destroy all that has already been accomplished. At the time of these interviews, there had been reports in the media of Renamo-orchestrated attacks in the central region of the country. This news was also causing much concern among the ex-combatant population. Many spoke of remembering that this was how it all started the last time (referring to the civil war). In the beginning, they heard on the radio about attacks happening far away, but before long, the fighting had reached their doorsteps. Some ex-combatants worried that if Renamo troops made it to their areas, ex-combatants would surely be the first ones to be targeted due to their close ties with Frelimo. There was great fear that war would turn the landscape "dirty" (Portuguese: sujo; Ciyaawo: munyalaye; murakale) ${ }^{74}$ once again. 
Yet despite these very real concerns over the changing political landscape of the country, most ex-combatants still continued to voice belief in the future progress and economic development of Mozambique. Adiana Matola speaks in these words:

I see that here in Mozambique now it is a country well-built and very beautiful. . . There is development/progress of the youth. They are FARMING, opening the country.... They have shops. The youth here are growing nyadyati [a type of bean]. ${ }^{75}$

The future progress of Mozambique rests on the shoulders of the young people. Adiana talks of the "development/progress [Ciyaawo: citukuko] of the youth." They are transforming the national landscape ("akuwugula cilaambo," which comes from "akuwugula ngunda" [clearing a field]) through building, cultivating the land, and by engaging in commercial activities. The "beauty" of Mozambique was often spoken in terms of the potential that Mozambique has in its natural resources (e.g., minerals, fertile land, and wild animals). Moreover, people spoke of Mozambique being a "good place," since they were observing how some people were managing to make good lives for themselves. Madalena Bitete talked of how she can appreciate the "beauty of Mozambique," since, as she says, "I see that all the people are getting/acquiring wealth, this one, that one, and yet another. Because this development is moving forward [digongo citukukoco kwenda]. "76 As the interviewees observed, the wealth of the nation is increasing (e.g., new resources are being discovered across the country, such as massive natural gas deposits off the coast of Cabo Delgado), ${ }^{77}$ and many people across the country are partaking in this economic progress. These accounts resonate strongly with the neoliberal development discourse of the Frelimo state. This "national discourse of the teleology of progress" hard enough, they will surely succeed in making a good life for themselves.

Although in state discourse, this is construed as a collective national future, it is clear that not everyone is equally privy to a share in the national riches. Celina, for instance, speaks of her relationship to Mozambique in the following words:

I see/experience that it is good. To say, THOSE-that's what I am saying, THOSE that live well in Mozambique they are doing well. UNLIKE me, who is not living well. . . I am saying, iih . . . this Mozambique is good, but it IS NOT good. It is a bit [good] BECAUSE I see/experience: those that HAVE give me a bit of salt. Because of this I say, bwe, it is preferable.... Yeah, if Mozambique wasn't good, even I couldn't eat salt ... yes.... Even ... good things one wouldn't see/experience, to say that this life here is good. But there I see that life is good: the enrichment of my friends, yes. ${ }^{79}$

At the time of this interview, Celina had not yet started receiving her pension. She was only observing how her DF friends in Mavago were living good lives. Though, as she explains, through social networks, some of their benefits 


\section{Beautiful belonging}

also trickle down to her. For this reason, she considers it better that some have wealth instead of everyone being equally poor. In Mozambique, there is great disparity in the development of the different regions. This is often noted with a great deal of dismay in Niassa. In the following interview segment, Rosa Chalamanda continues to talk about the different "scales of beauty" that she has observed across the different landscapes of Mozambique:

ROSA: Pa kuralala ni more. Rano ni [continues with laughter in her voice] nagarale gamo? Hehehe.

HELENA: [Speaks to Rosa] Eeh hehe. [Turns to speak to Jonna:] Disse que Moçambique todo é bonito. Agora eu escolher um lugar, hehe. Aí já conseguiu e me amarou mesmo.

ROSA: Hehehe, ah alakwe. Ana nakurale ku-Maputu, ku-Maputu-ko akutama wane. Rano wune ngangutama [continues speaking through laughter] ni nyile kuti mwakuralala? Hehehehehehehe.

HELENA speaks on top of Rosa's laughter: RANO nkurale m'mwe-jo kwakudi kore: kanga kwantemi-po, kanga kwi-Cinga, kanga ku-nono kuNampula, kanga ku-Tete. M'mwejo mwajenda-jendile-mo ni kupima kuti kwanti kula napite, kwanti napite, kwanti napite. Nambo malo ga nagweni kuti nambo apano, pakuralala. Ni parale pele-po.

ROSA: Wune ngupawona ku-Maputu [bursts into hysterical laughter], hehe, kwa napite kula [hysterical laughter continues], hehe.
ROSA: All the places are beautiful. Now [continues with laughter in her voice], I have to speak of one? Hehehe.

HELENA: [Speaks to Rosa:] Yes, hehe. [Turns to speak to Jonna:] She said that all of Mozambique is beautiful. Now for me to choose one place, hehe. You managed to tie my tongue.

ROSA: Hehehe, ah you. If I talk of Maputo, in Maputo other people are living [there]. Now I am not living [there] [continues speaking through laughter], and I have to say that it is beautiful? Hehehehehehehe.

HELENA speaks on top of Rosa's laughter: NOW you say whatever place: maybe there where you are sitting/living, maybe in Lichinga, maybe in Nampula, maybe in Tete. You, where you traveled and assessed that place X I went, place X I went, place X I went. But the place that you saw/experienced but, here, it is beautiful. Say that there.

ROSA: I see/experience in Maputo [bursts into hysterical laughter], hehe, there where I have been [hysterical laughter continues], hehe. 
HELENA joins in the laughter: Hehe. Essa aqui ... para rir só. Hehe. Disse "eu onde que eu vi bonito é Maputo. [Laughs as she speaks:] Mas só que é eu não vivo lá."

[Everyone joins in the laughter.]

JONNA: Mas visitou?

HELENA: Aah.

ROSA: Hehe. Kwele ni kwangupawona kuti, eeh, acijetu adi pa wutendele [starts laughing again] kwele-ko, hehe, yikutupoteka, hehehe.

HELENA joins her laughter: Hehe. Disse que Maputo quando cheguei, eu disse que aah sim, esses aqui estão bom mesmo. Mas eu não vivo lá. Estou aqui. [JONNA: Aah.] Mmm, agora ir dizer que a cidade de outro está bonito. Aah nada.

JONNA: E o que é que mais gostou de Maputo quando chegou-

HELENA: Pa mwayice ku-Maputu ca cin'nonyele m'mwe kuti nambo akuno kuralele. Kwana canti, kwana canti canti, kwana cici?

ROSA: kwekula kunonyele roni ni kwendajenda kula kwa kwamba kuuwa ngwelengwende! Wala yicici-nono yitela ngapagwa kwamba kuuwa basi sidade-pe bari. $\mathrm{Ni}$ nayiweni kuti nambo jamani acijetu akuno, wakutama apa [hysterical laughter starts again] akulama cenene, hehe.
HELENA joins in the laughter: Hehe, this one here is just laughing. Hehe. She said, "I, where I saw it was beautiful is Maputo. [Laughs as she speaks:] Only that I don't live there."

[Everyone joins in the laughter.]

JONNA: But you visited? HELENA: Yes.

ROSA: Hehe. There is where I see that, yes, my compatriots/friends are living well/peacefully [starts laughing again] there. Hehe, we are suffering, hehehe.

HELENA joins her laughter: Hehe, she said that Maputo, when I arrived, I said that, aah, yes, these here are living very well. But I don't live there. I am here. [JONNA: Aah.] Mmm, now to go and say that the city of another is beautiful. Aah no.

JONNA: And what is it that you most liked about Maputo when you arrived-

HELENA: When you arrived in Maputo what did you like? To say, but here it is beautiful. It has this [thing], this [thing]. It has this [thing], this [thing]. What does it have?

ROSA: I liked it there: Even walking around it is clean/clear! Even what-even trees it doesn't have, only the city, only. And I saw that, yes, our compatriots/friends here, those that are living here [hysterical laughter starts again], they are living well, hehe. 
HELENA joins her laughter: Hehe, disse o que eu gostei de Maputo quando cheguei lá . . . Desci . . . no avião. Reparar assim: até LÁ longe não tem montanha, não tem árvores. Eu gostei. SÓ ver casas e praias, $\underline{\mathrm{SO}}$.

JONNA: Hehe. Está cansada com essas montanhas do Niassa? Heh.

HELENA asks laughingly: Hehe, mperile nago matumbi ga kumangwenu kuno, hehe.

ROSA joins her laughter: Hehe, eish, capim, hehe.
HELENA joins her laughter: Hehe, she said that what I liked in Maputo when I arrived there ... I got off ... the plane. I looked around like this: Even THERE far away, there are no mountains, there are no trees. I liked. ONLY to see houses and beaches, ONLY.

JONNA: Hehe. Are you tired of these mountains of Niassa? Heh.

HELENA asks laughingly: Hehe, did you get tired of the mountains of your homeland here, hehe.

ROSA joins her laughter: Hehe, goodness, weeds, hehe. ${ }^{81}$

Rhythms, as Lefebvre points out, are relative; their "speed, frequency and consistency" only make sense in relation to the other rhythms to which they are connected. ${ }^{82}$ In the interview accounts, Mozambique as a whole is often observed to be a beautiful polyrhythmic assemblage. As Rosa laughingly exclaims, "All the places are beautiful. Now, I have to speak of one?” Still, often, as the interviews show, one's own life rhythm is perceived as not being quite in tune with these beautiful rhythms of the others coming together in their own eurhythmic spatiotemporalities. Rosa's words, for instance, point to her experience of being out of sync with capitalist modernization and its quintessential "clean" landscape, the city. ${ }^{83}$ Rosa's life rhythm is embedded in another spatiotemporal existence in Niassa. This is the landscape to which she belongs and which belongs to her. Rosa's account speaks volumes about the politics of access. Maputo is not reachable for her. She is allowed a distanced viewing from where she can imagine the "good" lives lived by others there. The freedom of movement and her increased mobility, which she spoke of in the beginning of the conversation (see page 200), is shown to have very real limits. Though her mind reaches further and conceptually engages with the whole of Mozambique, it is her province of Niassa (and especially its northern part) that is within her actual bodily reach.

Rosa's words, and especially her laughter, suggest the alienating experience that "beauty" can be when we discover that our bodies are outside, out of tune with the rhythms that we perceive to constitute the beautiful. In many excombatant accounts, aesthetic pleasure and satisfaction is associated with urban rhythms. Robin James Smith and Kevin Hetherington write that "the urban has an intrinsically rhythmic organization which, in turn, gives rise to specific 
forms, configurations and relations of space, time, interaction and mobility." ${ }^{4}$ My interviewees, however, did not speak of wanting to move to the city. They spoke instead of their desire to experience their home villages transformed and incorporated into this urban rhythmicity. This involves the construction of modern housing and better roads and the increased movement of goods and people. For many, their point of reference is Lichinga. The provincial capital Lichinga has a very young urban history. It was first established as a military post by the Portuguese in 1932, named Vila Cabral in 1945, and elevated to city status in $1962 .{ }^{85}$ Situated on the highest point of the Lichinga plateau (at an altitude of 1360 meters), it provided the perfect strategic location for the Portuguese military to oversee the surrounding landscape. Like other Mozambican colonial cities, its physical structures bear the imprint of racial stratification. The cement center with its "modern" urban infrastructure was the space of the Portuguese citizens while the colonial subjects, the black workers, resided in the surrounding bairros in traditional dwellings. The small compact cement heart (with a radius of about half a kilometer) is still today a very discernible feature of the cityscape (see Maps $6.3 \mathrm{a}$ and $6.3 \mathrm{~b}$ on page 206). Nevertheless, it has been shaped by new spatial narratives and practices. The Institute for Public Administration now occupies the old military compound. The colonial Praça has been transformed into the Praça da Liberdade that hosts a 3.27 meters high bronze statue of Samora Machel (inaugurated in 2012 and identical to others dispersed across the country) as well as a permanent exhibition of his political personhood. The religious diversity of the city dwellers also manifests itself here. On three sides, the Praça is surrounded by a mosque, a Catholic church, and a protestant church (Igreja Universal do Reino de Deus) that now occupies the former Portuguese-era cinema. The crisp white building of the provincial Frelimo party office with its red flags also claims a prominent position along the main boulevard. Otherwise, the "cement city" is taken up by state administrative buildings, several banks, phone companies, a few schools, and the central hospital, as well as some small businesses, a hotel and a few inns, mostly Indian-owned shops, and some older residential buildings. The central market is located on the fringes of the cement city in one of the city's oldest neighborhoods, Muchenga. While at independence, the city had a population of about 40,000 inhabitants, now its 180,000 -strong population spreads across a total of fifteen bairros that expand across an area of $257 \mathrm{~km}^{2} .{ }^{86}$ Most of these neighborhoods are accessed by poorly managed dirt roads. No chapas operate within the city. Some well-off people have cars, and more and more city dwellers have motorbikes, but still, walking is the most commonly used way of navigating the cityscape.

In urban studies, urban rhythms are usually defined through notions such as velocity and the intense flows of information, people, and objects. ${ }^{87}$ Lichinga manifests a different kind of urbanity; its rhythms intimately entangle with the rural landscape. Lichinga is a small-scale city that moves at a slower pace than some of the other provincial capitals. Despite its remoteness in the national 


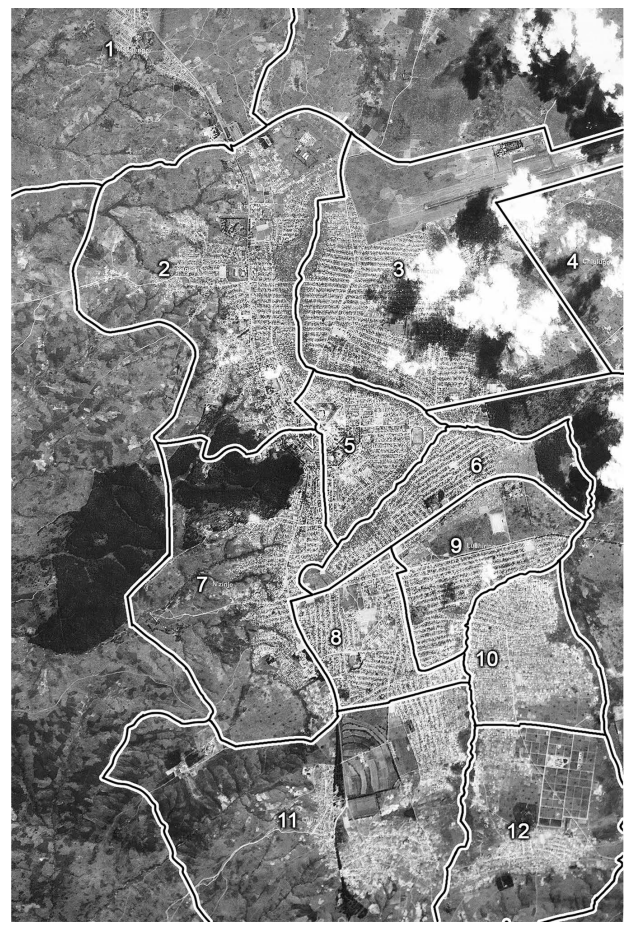

Maps 6.3a/b City of Lichinga/central bairros of Lichinga

Source: Photographs of a map provided by the Department of Urbanization and Housing at the City of Lichinga; edited by Mikko Kankaanpää

Names of bairros shown on Map 6.3a:

1 Massenjer

2 Sanjala

3 Namacula

4 Chiulugo

5 Muchenga

6 Cerâmica

7 N'zinje

8 Estação

9 Luchiringo

1023 de Setembro

11 Lulimile

12 Nomba

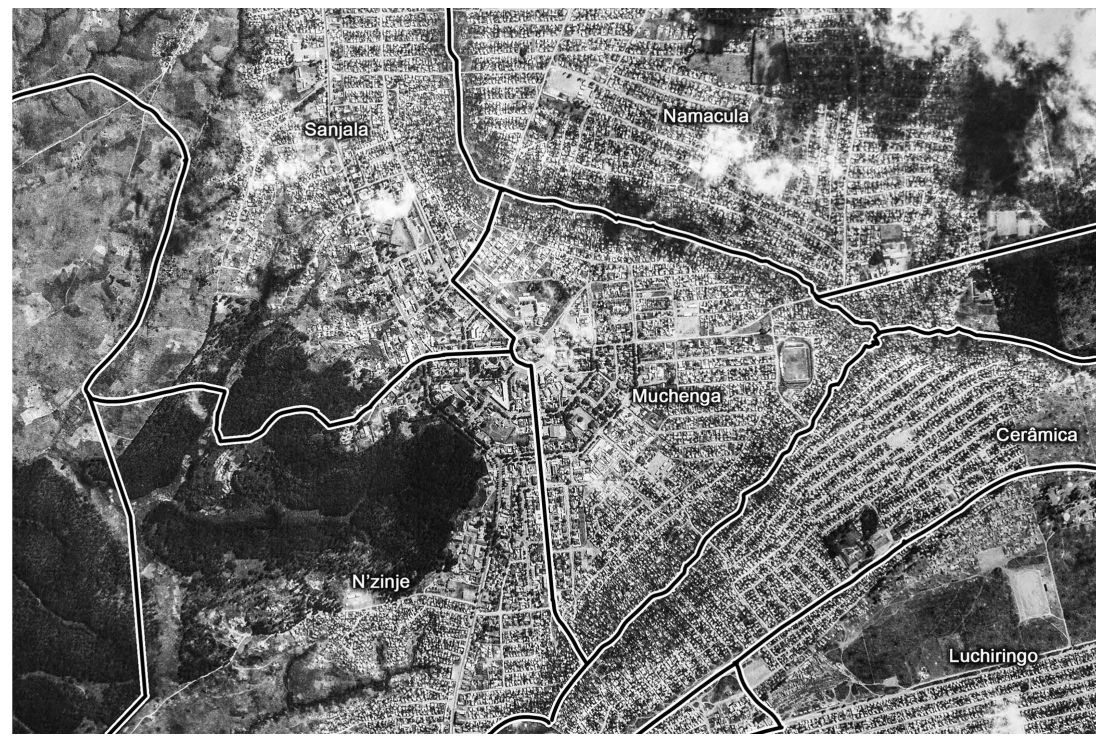


landscape, it is by no means isolated: state time pulses through its heart and connects the city to the central state machinery in Maputo. These rhythms are perceivably embodied in state institutions (e.g., schools, hospitals and health centers, and offices of the provincial government). In mundane and often invisible ways, they contribute to the totalizing power of what Homi Bhabha refers to as "nationalist pedagogy." 88 Still, the state is not the only actor shaping the cityscape. The city resonates the recognizable rhythms of the global market economy be it with a significantly reduced tempo and different style. Vietnamese mobile phones and Chinese motorbikes are perhaps the most striking symbols of global capitalism. Even small cities like Lichinga are not homogenous landscapes but composed of a multiplicity of lifeworlds. The citizens themselves shape the city through their movement. These lifeworlds have their own centers (and margins). For the ex-combatants, the "cement city" marks an important focal point. Every month for a few days, hundreds of ex-combatants crowd the surroundings of Barclays Bank to queue for their veterans' pensions. Many of these ex-combatants are not city dwellers. They only come to collect their money. Then they head back to their home villages. But every month for these few days, the surroundings of the bank turn into a minor spectacle, a noisy gathering of ex-combatants and street vendors trying to make a profit. The city's actual commercial hub lies only a block away. At the central market, the city's trading activities converge most intensely (visibly, audibly, olfactorily!) with a reliable hectic rhythm. This is also the point of departure for all the chapas that connect the city with the larger landscape of Niassa.

Lichinga is a city with strong rural linkages. The linear rhythms of the bureaucrats' and shopkeepers' clock-time intermingle with the seasonal rhythms of agricultural production. Most of Lichinga's inhabitants rely on their machambas to meet their basic consumption needs. A few of the DFs I interviewed had machambas in the green zones of the city, but the majority cultivated their fields at some distance from Lichinga. In the beginning of the rainy season and during the harvest time, they usually relocate to their machambas for weeks at a time. Even though they live in the city, their lifestyles are a combination of both rural and urban. Going outside of Lichinga, good lands with rich soil and sufficient water are still relatively accessible, though, for instance, multinational forest companies have been laying claim to more and more land around the Lichinga plateau for their tree plantations. The idea of good farming land dominates people's perceptions of the Niassa landscape. As Helena Caisse phrases it, "The place that is very beautiful here in Mozambique-leaving construction asideif it is about food, my friend, it is here in Niassa." ${ }^{89}$ Niassa is experienced as having much to contribute to the agricultural development of the country. These ideas are, of course, also shaped by the memory of the "golden age" of socialist collectivism and its vision of the rapid modernization of the landscape through large-scale state farms. Niassa has not experienced much capitalist development, as Helena comments. Lichinga has only some small-scale agro-processing 
industries. ${ }^{90}$ Maria Ajaba, who has lived in Lichinga since independence, speaks of her dream of seeing factories in Lichinga. Through factories, she claims,

this Lichinga here could be born . . . like those things that come out at NIGHT. Mm? SHINING at night there above-everything becoming white! Eeh? They could be here on the ground also like this ... the future. ${ }^{91}$

This industrial future, though often recognized as a utopian dream, continues to animate the sensory imagination of many ex-combatants who hope that Niassa could also more fully participate in this urbanized modernity.

The way people want to shape their environment shows, in the words of environmental aesthetician Yrjö Sepänmaa, "a culture and order of values." ${ }^{2}$ A group of male ex-combatants spoke of their desire for the city of industrial modernity. Here, Mwemedi N'tawula speaks of his hopes for Mavago:

I, here . . . I will comment/add. BUT the thing that I will add, I won't add something different. I, the thing that I will comment is to bemoan for those ... foreigners ... to [come] STAY in this country. We are-we are suffering ... but we have a lot of riches now. We have a lot fertile land. But these fertile lands, if the foreigners were here working on them, Mavago here could grow/develop more. Sister, and this district here . . is big! It isn't like a district. It is a whole province. Do you see? Here, just to leave from here, to arrive in Rovuma [it's far]. We are just living there. We are only giving [land] to people who are coming from South Africa to kill those animals. There is nothing that we are gaining from it. But if those with factories would come, there, you see, in Mavago, there is a place to cultivate ... that thing ... rice. And to cultivate that thing ... have a field of that thing ... of mikoloro [sic; meaning unclear].... Even coconut they could plant here. We could do like [they do] in Zambezia. THAT'S what's making us sad. Indeed, I am becoming sad. What I want to add, and cry is that the FOREIGNERS have to come to this country here ... to this our district of Mavago here to open ... factories and open machambas, yes. NOT those that are killing animals. That isn't bringing anything for us. Hehehe. $^{93}$

Mwemedi evokes an idea of Mozambique as a country that can be coinhabited by people of diverse backgrounds. It is common to hear these kinds of thoughts expressed among the ex-combatant population. They did, after all, experience firsthand the solidarity of countries such as China, the Soviet Union and other Eastern bloc countries during the liberation struggle and in the immediate period after the war. ${ }^{94}$ In the first years of independence, an economy and society organized according to socialist principles seemed a viable modernist dream. The project of Empresa 400 mil hectares in Unango that I wrote about in the previous subchapter is a prime example. My interviewees 
remembered this joint Mozambican and foreign engagement in the shaping of the Niassa landscape with special nostalgia. The hopeful dream of modernization still persists. As Mwemedi argues, Niassa has a vast terrain that can be shared with foreigners who are interested in investing in the land and furthering its development and modernization. As he insists, "If the foreigners were here working on them [these lands], Mavago here could grow/develop more." It is not all foreigners and landscape developments he welcomes with open arms, however. He is highly critical of the tourist industry that brings affluent visitors into the hunting blocks of the Niassa national reserve (the largest protected area in Mozambique with its area of $\left.42,000 \mathrm{~km}^{2}\right)^{95}$ to shoot wildlife. This brings little economic revenue for the local people. Those living in the area, for instance, in Mavago, are not legally permitted to hunt animals such as antelopes for meat. People generally spoke of their yearning for foreign investment and businesses to bring new employment opportunities and new sources of income for the communities. These kinds of developments, people seemed to believe, could lead to a more "modern" way of dwelling in landscape. Modernity, as I suggest, is best understood through the notion of the beautiful - the different meanings of which are negotiated in the bodylandscape relationship. ${ }^{96}$ In the ex-combatants' narratives, these negotiations (as Mwemedi's account shows) are often entwined with a critique of the failed socialist modernization project as well as the unequalizing and individualistic effects of the capitalist agenda.

In the beginning of the 1980 s, the Frelimo state was forced to admit the failure of the socialist-planned economy and face its highly discontented populations. The economic crisis was further acerbated by the civil war that started soon after independence. In effect, Frelimo radically changed course. The economy was opened for neoliberal transformations, and, to quote Lefebvre, the "rhythms of capitalist accumulation" 97 began to guide state development policies. The process of privatization accelerated further in 1987 when Frelimo adopted an International Monetary Fund imposed structural adjustment program. The nationalist elites have since become closely aligned with the interests of global capital. These elites are the ones who have mostly benefited from the liberalization of the economy. The economic policies have increasingly emphasized large-scale foreign investment in megaprojects and the extraction of natural resources. Coal mining and the export of liquefied natural gas are expected to be the key drivers of economic growth in the years to come. ${ }^{98}$ But while Mozambique has experienced strong economic growth (7.4 percent in 2014), at the same time, these processes have created more inequality and poverty. ${ }^{99}$ In the ex-combatants' accounts, certain socialist ideals continue to coexist and influence their understanding of the current state development discourse and the body-landscape relationship that it prescribes. The government's policies of market individualism are juxtaposed with the egalitarian ideals of socialist collectivism. Neoliberal capitalism has contributed to the continued marginalization of Niassa. As Rosa's words show next, ex-combatants are expecting 
the state to take a more interventionist role in equalizing and extending development to the provinces. I had the following conversation with Rosa at her machamba in Muembe:

ROSA: Now ... I would like what? ... I would like that ... this PHASE THAT WE ARE IN ... to add one more phase ... right? ... Like this . . we are here ... [Continues in a very quiet voice:] When we sat down/settled down with our lives, we started to farm ... I don't know ... for us to have food ... to go and ... like this [few words inaudible because of strong wind]. So I would like for ANOTHER PHASE TO ARRIVE, a time of ... more improvement. Because like this at times we are suffering always with the HOE. ... We are farming with a hoe. Because ... we could at least ... if it were ... if it were easy, at least, we would have ... those hoes to farm, FOR US TO REST at least. Hehe. To . . . have another more advanced phase.

JONNA: But what kind of phase? What type of things? Heh.

ROSA: FOR TRACTORS TO COME ... to help us. Hehehe. [JONNA also laughs: Aah, aah, yes, yes, hehe.] Hehehe. FOR US AT LEAST TO REST a bit, right? . . Y Yes. To have help in the machambas that these, we-I mean, the government sometimes ...THEY talk... . But up to here/this place ... not yet . . those tractors have [not] arrived. These tractors to farm exist but up to here/this place ... not any phase are we seeing here that ... [the tractor] worked here, that there are people who are resting, I don't know what, no. Heh.

JONNA: Heh, because it is very tough work?

ROSA: It is very tough work. This? When it starts, it is only for a person to lose weight only. With the HOE only. Can you imagine? To start from here [continues in an elevated pitch] TO ARRIVE THERE AT THE BOT$\underline{\text { TOM, you will need months }}$ to finish. But like this with tractors you can plow in two days ... and it's done. ${ }^{100}$

Similarly to the other DFs, Rosa speaks appreciatingly of the relationship of peaceful dwelling that she has with the landscape. But in her opinion, this is only the first phase, and she is expecting a second phase to come that would mean an even better experience of dwelling. She argues that the government has made promises of bringing more advanced technology to Niassa that would significantly transform the arduous and backbreaking process of traditional farming. She complains that her muscles get really stiff, and her whole body feels sore after a whole day working in the machamba. Her machamba is on a hillside that slopes into a small river, and as she explains, working by herself with a hoe in hand, it takes her a long time to prepare the field for sowing. According to her, this job could be done in a few days with the help of a tractor. But the government's promises of bringing advanced farming equipment to Niassa have yet to materialize. 
Among the ex-combatants, as I have already discussed, there is a strong belief that Frelimo is the only capable guardian of the state that can bring development to the country. As Helena argues,

The government - the party Frelimo has to WIN to continue to construct ... to organize, to say, to ARRANGE . . ROADS . . to arrange bridges. This energy from Cahora Bassa has to advance to the districts ... to every province. Because ... the issue that is very, very [difficult] is the issue of ROADS and energy. Where they suffer is in the provinces. ${ }^{101}$

Helena acknowledges that Niassa is not the only province suffering from the lack of infrastructure. She, moreover, continues to make a strong point for the need of tar roads in Niassa:

This road number one ... has to be tarred ... connecting up to ... to Tete ... to go to Chimoio, up to Maputo. Here, also tarred up to Nampula. Here, to finish this tar road up to Cabo Delgado. Here, also to be tarred up to Segundo Congresso, for people to connect to Tanzania. Then here also TARRED to Mavago. Because Mavago is where there is wealth for people to confide in. It is in Segundo Congresso and in Mavago where there is GOLD, elephants ... and they have that thing ... I don't know what they call it, giraffe. That animal that has ... one ear ... only one ear like this, but in THIS EAR, it has gold. ... It has gold. It has gold. It is there in Mavago, from Mavago to Mecula. So there in Mavago a road has to be opened up to N'sawisi. There in N'sawisi to continue up to our Base Katembe, the base of the female detachment, PASSING through to Mecula, connecting to Mecula. There they have ... wealth and

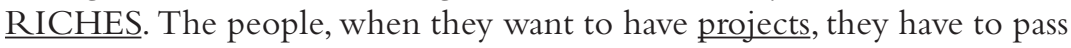
in those zones there. ${ }^{102}$

This new and improved network of roads, as Helena argues, would give the population better access to the riches of Niassa, and people would, for instance, be able to start mining projects. Helena speaks of the district of Mavago where small-scale ruby mining activity is going on in the N'sawisi area, close to where the DFs of the eastern war front worked during the war. Many fabulous stories circulate around Niassa that speak of the legendary riches that the land possesses. These stories are fueled by media reports of the neighboring provinces of Cabo Delgado and Tete profiting from the natural resources found in their territories (natural gas in Cabo Delgado and coal in Tete). These stories bring hope to people who see little "progress" in Niassa. Often, in the stories circulating in Niassa, access is considered to be the biggest problem. Obtaining a mining license, for instance, is a highly bureaucratic process. Moreover, the poor condition of the road infrastructure, as Helena argues, also makes it difficult to access these places. Chapas do not frequent the notoriously demanding 


\section{Beautiful belonging}

stretch of dirt road between Mavago town and N'sawisi. Despite political promises made during election times, in 2014 there were still only three tarred roads in Niassa. The Lichinga-Metangula stretch (extending about $100 \mathrm{~km}$ ) is an old road that connects Lichinga to Lake Niassa. The Portuguese had an important naval base in Metangula during colonial times. The second tar road connects Lichinga to Unango, the site of an important military post during colonial times. Finally, the Lichinga-Marrupa road (which covers bit over $300 \mathrm{~km}$ ) is a new road that leads east toward Pemba, the capital of Cabo Delgado, though the road is tarred only up to Marrupa. The lack of roads in Niassa, as well as roads connecting Niassa to the rest of the country, is not a problem only raised by the ex-combatants. It has been a contentious issue for years. Again in 2014, it dominated the discussion during President Guebuza's visit (referred to by the term "open presidency") in Niassa. ${ }^{103}$ Especially during the rainy season, some of the roads become almost impassable. Lichinga municipal reports recognize the lack of roads as a major hindrance to the economic development of Niassa. ${ }^{104}$ The absence of a sufficient road network also impedes closer regional economic integration.

Since 2010, the Unity Bridge (Ponte da Unidade) over Rovuma River has connected Niassa to Tanzania. For many ex-combatants, it carries strong symbolism. I crossed the bridge on foot with Helena and a male ex-combatant called Mussa Ause. Mussa lives in Lichinga but resides part of the time in Matchedje, where he has an agricultural project with a group of other ex-combatants. Being in the company of ex-combatants (the "owners of this place" [donos daqui] as Helena and Mussa on various occasions proudly identified themselves), the border guards also allow me to take a small walk into Tanzania. As we cross the river, Mussa - performing the role of the tour guide-directs my attention to the political significance of the seemingly unimposing waterway that we so leisurely pass over on our evening walk. "This is that Rovuma of Rovuma to Maputo!” he authoritatively informs me. Rovuma River marks the northern territorial boundary of national space. FRELIMO had a strong influence and presence in this borderland region during the war. The border village of Matchedje is especially important in nationalist history for it hosted FRELIMO's Second Congress in 1968. The site of the Second Congress has now been reconstituted as a "local histórico," a site of commemoration (see also Figure 3.1 on page 100). Thus the place is also referred to as "Segundo Congresso" (II Congresso). One female ex-combatant Rosa Namate, whom I interviewed in Matchedje, spoke of how it had been her dream since the liberation struggle to build her house in Segundo Congresso. As she says, "Because there at Congresso I lived a long time at that base. I started to want that place a long time ago." ${ }^{105}$ She only very recently relocated from Macaloge to there. I even conducted two of the first interviews (out of our series of three) with her in Macaloge. She and some of the other ex-combatants living in Congresso spoke of how a certain area had been set aside as a place where ex-combatants could build their houses. Rosa spoke of how she was building her house in anticipation of the movement and business opportunities that the transnational 
road connection between Tanzania and Mozambique was expected to bring to the area at some point. Though for now, the $250 \mathrm{~km}$ stretch of mostly untarred road connecting Matchedje to Lichinga is a challenge to travel, and movement of goods and people is still to pick up pace. Ex-combatants' narratives speak of how their experience of Niassa is shaped by a sense of disconnectedness from the national landscape. The nationalist spatial concept "Mozambique of Rovuma to Maputo" is not a wholly consolidated spatial experience for everyone.

The rural population of northern Niassa is in no sense a homogenous mass, but significant differences exist in their lifestyles. People also have differentiated access to monetary income and consumer goods. Accumulated surplus is mainly invested in casas melhoradas (or improved houses), ${ }^{106}$ motorbikes, and better food, for instance, meat (which is not a common part of people's everyday diets). In the rural areas, the ex-combatants with their pensions belong to the more affluent segment of the population. Male ex-combatants especially, many of whom receive bigger pensions, have been able to start small agricultural projects growing cash crops and thus improve the quality of their lives. The ex-combatant houses, for instance, often stand out in the landscape of rural Niassa. For most ex-combatants, the house has a very strong symbolic value. Many ex-combatants argue that it is their legacy; it demonstrates the significance of their lives. One's house tells one's life narrative. Still, the excombatant house is both a happy object and unhappy object of difference. ${ }^{107} \mathrm{It}$ is linked to both beautiful and negative aesthetics. In many places, these houses are related to negative "social aesthetics." 108 According to ex-combatants, they are the cause of much jealousy with their neighbors. In the rural areas, many ex-combatants spoke of the social friction they experience with their neighbors. As Rosa explains, "When a person has [better material conditions] they start to speak badly of the person because he has." 109 This was a topic widely discussed in the interviews and a big concern for many ex-combatants. Some even expressed wanting to relocate their homes because the social relations of their current homeplace had gotten so bad. Rosa Chalamanda in N'kalapa argued that her neighbors, in their jealousy, had resorted to witchcraft, which had caused the death of three of her children. ${ }^{110}$ She spoke of how she wanted to leave N'kalapa, but she could not convince her husband to go with her, so she was stuck. Several ex-combatants even spoke of wanting a place that was just for ex-combatants - a place in which they could dwell peacefully. Rosa elaborates:

ROSA: Iih, a lot [of people have issues with ex-combatants] ... mm ... A LOT. TO THE POINT THAT IF IT WERE THAT . . . at least . . . if we STAYED ON THE SIDE, THE OTHER SIDE, WE ONLY. Y ou couldhehehe. [JONNA also joins her laughter.] [Rosa continues with laughter in her voice:] You could say that, $\underline{\text { iih }}$, we will live on the other side, which is for us only.

JONNA: But what side? 


\section{Beautiful belonging}

ROSA: Because the people-NO, but right HERE in Mozambique . . . TO CHOOSE ONE PLACE and say that this place here, these people here have to live like this here. Because like this, when we are mixed, uhmm, many people [continues to speak in a very low voice] don't like us. . . Even though - they don't know that it was we that liberated this country here ... [continues in a lower voice] for them to live well. But now they don't like [us] ... LIKE THIS, as we are mixed like this ... they start to talk badly of us. ${ }^{111}$

In the rural areas, the ex-combatants tend to stand out. They are perceived to embody a different lifestyle from their neighbors. This often creates social tensions, and many ex-combatants talk about the animosity directed toward them by the civilian population. As Rosa explains, "Many people don't like us." Lichinga, however, is different because it has a bigger ex-combatant population. The income differences are also more diverse, and the ex-combatants blend in. Still, for instance, Tito argues that even in Lichinga, the ex-combatants should live more closely together.

We should, as men of war-they say that we ... we are pensioners. Yes. We could stay in one place ... [a place that is] ours.... For example, there can be more mixture, right? But while we know all of us who are there in that place. ... Our personal jobs ... being from there ... doing ... collective jobs. So it is the state that can think of collective jobs. So then one can work very fast. ${ }^{112}$

Tito's words speak of his idealization of another era, and his yearning to recreate those social relationships and collective alliances. Many ex-combatant narratives speak of disturbances in ex-combatant-civilian relationships. Excombatants feel more aligned with each other than with the larger national community. Still, the ex-combatant community has also been divided between those merged in more urban lifestyles (especially in Maputo) and those closely tied to the rural landscapes.

Every individual contributes to the social harmony of place. This is a theme that comes up in many interviews. Social harmony involves adjusting one's life rhythm to fit together with those of others. Social harmony is also closely tied to local ideas of social justice. Rosa Salimu's account speaks of the importance of every individual knowing how to live as part of the society.

I, as I am a person who knows how to live ... they see/experience that we are living well with others. And the children, they also live by themselves their own lives ... like I here in this place, as I live here. Because I am living and waking up with my children following their [the community's] rules and saying that ... we are living well, yes. THOSE that see/experience that we are not living well, it is because they provoke the people that are 
around them.... And ... if I were to argue [with people], I would see/ experience that this life is not going well for me. But like we here, we are living well. ${ }^{113}$

For instance, the main purpose of unyago (the initiation rite), as the women's narratives describe, was to teach through the notion of "wucimbicimbi" the harmonious co-dwelling between self and other. The social ideal is eurhythmia in which individual rhythms harmoniously relate to the group. Those who break the social rhythm of the group must expect to be disciplined. Some of the ex-combatant narratives point to an experience of being rhythmically out of sync. When these disturbances become chronic, as Lefebvre theorizes, they become arrhythmia. As he writes, "In arrhythmia, rhythms break apart, alter and bypass synchronization." 114 This social arrhythmia can also manifest itself as a bodily illness. This helps to understand why illness and death are often explained resulting from one's bad relations with one's neighbors or other people in one's community. In the case of some ex-combatants, these social disturbances have become chronic. These ex-combatants spoke of their desire to reestablish their lives within another social community that might be more accommodating of their difference. For others, an ex-combatant community was the only group in which they imagined cohabitating in peace.

Finally, I refocus on the measure of all rhythms: the body. The different rhythms of landscape, as I have explored, are lived through the body. Moreover, the body-landscape relationship is continuously shaped by the changing social times. The ex-combatants tend to remember the first years of socialist collectivism with a certain nostalgia. For many of them, it was a hopeful time in which an egalitarian future seemed possible. Many of the ex-combatants I interviewed remembered living good lives in those first years of independence. First, the violent tactility of the body-landscape relationship of the wartime was transformed into a relationship of peaceful dwelling. Second, the new state was demonstrating its strength and making its presence felt by transforming the bush into collective farms and communal villages. I do not mean to downplay the negative effects that these economic and social interventions had on many people. Yet the ex-combatants' narratives emphasize the positive aspects. In their memories, Niassa at the time was gaining from national and transnational development efforts; it was being integrated into the national landscape. These first good years of independence are juxtaposed with the time in which they witnessed the decline and failure of this modernist dream. For many of them, this coincided with their demobilization and return to civilian life. Also, the war between the Frelimo state and RENAMO commenced already in 1977. The fighting spread to Niassa in the early 1980s, disrupting people's lives and livelihoods in many ways. By the late 1980s, the government had already completely abandoned its socialist ideology and opened up to the neoliberal capitalist transformation of its economy and society. While the elite in Maputo benefited from 


\section{Beautiful belonging}

the privatization of state assets and managed to accumulate great wealth, the ex-combatants in Niassa mostly experienced economic marginalization. Through the years, the Mozambican economy has grown, but only a small percentage of the population has benefited. For ex-combatants, these changing economic rhythms have not significantly improved their lifestyles and "modernized" their body-landscape relationship. The desired modern lifestyle is in their view embodied by the urban dwellers of the bigger Mozambican cities, such as Maputo and Beira. At the same time, the remembered socialist rhythms of a bygone era also continue to influence the landscape experiences of ex-combatants. Social rhythms change slowly and thus, as Edensor writes, "offer a consistency to place and landscape over time." 115 Despite the state discourse having changed in favor of capitalist modernity, the ex-combatant community in Niassa continue to draw on both socialist imaginings and local notions of social harmony and justice when talking of their desired body-landscape relationship. At present, the overwhelming sentiment expressed in the ex-combatant narratives is that they are not fully merged within the rhythmic beauty of the national landscape. As I have shown, the desired aesthetic engagement between body and landscape is that of peaceful dwelling. In the final chapter, I will develop this argument further and show how body aesthetics contributes to a reconceptualization of "belonging." As I suggest, "belonging" is not a subjective experience but is shaped and negotiated in a reciprocal relationship between body and world.

\section{Notes}

1 Interview with Fátima Issa Chipande, Mavago district, August 7, 2013.

2 Gernot Böhme, "Urban Atmospheres: Charting New Directions for Architecture and Urban Planning," in Architectural Atmospheres: On the Experience and Politics of Architecture, ed. Christian Borch (Basel: Birkhäuser, 2014), 51.

3 Ash Amin, "The Good City," Urban Studies 43, nos. 5-6 (2006): 1009-1023.

4 Böhme, "Urban Atmospheres," 45.

5 Gernot Böhme, "Atmosphere as the Fundamental Concept of a New Aesthetics," Thesis Eleven 36 (1993): 122.

6 Ibid.

7 Arnold Berleant, "Aesthetic Engagement and the Human Landscape" (paper presented at the International Conference on Environment, Aesthetic Engagement, and the Public Sphere, Paris, May 9, 2007); Berleant, Living in the Landscape, 35-36.

8 Western aesthetics has traditionally concerned itself with the aesthetics of objects and has thus been characterized by a passive subject-object engagement (defined as "disinterestedness”). More recently, as Guðbjörg Rannveig Jóhannesdóttir writes, radical redefinitions of the concept of beauty have emerged within the discipline. Jóhannesdóttir, "Icelandic Landscapes: Beauty and the Aesthetic in Environmental DecisionMaking” (PhD diss., University of Iceland, 2015). In this study, I mainly focus on Arnold Berleant's aesthetic theory.

9 See also Johnson, Retrieval of the Beautiful, 39.

10 Berleant, "Aesthetic Engagement."

11 Berleant, Living in the Landscape, 111.

12 Ibid., 110.

13 See Johnson, Retrieval of the Beautiful. 
14 Tobacco is the most widely grown cash crop in Niassa followed by cotton. INE, Censo agro-pecuário CAP 2009-2010: resultados definitivos—Moçambique (Maputo: INE, 2011).

15 Ministério da Administração Estatal, Perfil do distrito de Mavago província de Niassa, (Maputo: Ministério da Administração Estatal, República de Moçambique, 2005).

16 Mwemedi Alifa in group interview with male ex-combatants, Mavago district, August 8, 2013.

17 According to statistics, there are more zinc-roofed houses in the district of Mavago than in Muembe. André Jonas, “Mavago em crescimento," Notícias (Maputo), October 1, 2013.

18 Sara Ahmed, The Promise of Happiness (Durham, NC: Duke University Press, 2010), 41.

19 Interview with Lúcia Ali Abdala, Sanga district, May 30, 2013.

20 Simon Anstey, "Institutional Change and Community Based Natural Resource Management in Northern Mozambique: The Village Goes Forward: Governance and Natural Resources in North Niassa" (PhD diss., University of Zimbabwe, 2009). Anstey writes that before the 1950s, most settlements were located in the area of Unango Mountain. From the 1950s to the 1960s, these settlements expanded northward up to the Rovuma River.

21 Interview with Lúcia Ali Abdala, Sanga district, July 19, 2013.

22 E.g. Henriksen, "Marxism and Mozambique," 449.

23 Ibid.

24 See Machava, "The Morality of Revolution."

25 Some of these camps were supposedly created to deal with the "problem of prostitutes" in Maputo. See, e.g., "Frelimo cria campos de reeducação," A Capital (Lisbon), November 20, 1974, accessed March 26, 2016, www.mozambiquehistory.net/justice/reeduca tion/19741120_frelimo_cria_campos.pdf. See also Cabrita, Mozambique, 97. Most of the people sent to Niassa had no survival skills for these kinds of environments, and many actually died. Others eventually moved to Lichinga, where many of their decedents can these days be found working at the central market.

26 Cabrita, Mozambique. Although Cabrita argues that it is difficult to know the exact number of reeducation camps, he estimates that by the late 1980s, there were at least twenty-four spread over seven provinces. Nine of the twenty-four were located in Niassa. According to Cabrita, Niassa "to all intents and purposes became a penal colony" (96).

27 According to an article published in the national newspaper Noticias about the center of reeducation in N'sawisi in 1976, the camp housed 501 prostitutes, women accused of sorcery, and Jehovah's witnesses who had been brought there from different parts of the country. A platoon of thirty-eight DFs oversaw the administration, organization, and political mobilization of the detainees. As the commander of the base explained, "We will be training free Mozambican women who will be able to contribute actively to the Mozambican revolution." "Centro de reeducação de Msauíze: transformar pelo trabalho marginais da sociedade colonial," Notícias (Maputo), August 13,1976, 4. See also Machava, "The Morality of Revolution."

28 Interview with Beatriz Assima, Lichinga, February 20, 2013.

29 The National Security Service even gained power to send people to these camps without trial. Margaret Hall and Tom Young, Confronting Leviathan: Mozambique since Independence (London: Hurst \& Company, 1997), 47.

30 See, for instance, Samora Machel's speech in defense of reeducation camps. "Machel's Speech on Unjust Detentions in Re-Education Camps," BBC Summary of World Broadcasts (London), no. ME/6846, October 6, 1981, B/1.

31 Sheldon argues that the "modernity" advocated by the political elite was also shaped by their experience of mission education. Pounders of Grain, 117.

32 During the socialist period, Frelimo held a very hostile attitude toward the city. See Paul Jenkins, "Image of the City in Mozambique: Civilization, Parasite, Engine of Growth or Place of Opportunity," in African Urban Economies: Viability, Vitality, or Vitiation?, eds. Deborah Fahy Bryceson and Deborah Potts (New York: Palgrave Macmillan, 2006), 107-130. 
33 "Correcção de deficiências na operação produção: Ministro Guebuza esteve no Niassa," Notícias (Maputo), April 10, 1984, accessed March 26, 2016, www.mozambiquehistory. net/history/operacao_producao/19840410_deficiencies_of_operation.pdf.

34 "Sérgio Vieira, Governador do Niassa, a 'O Jornal': uma das consequências da operação produção será o desenvolvimento do português," O Jornal (Lisbon), October 7, 1983, accessed March 26, 2016, www.mozambiquehistory.net/history/operacao_produ cao/19831007_sergio_says_portuguese_will_develop.pdf.

35 Machava, "The Morality of Revolution."

36 Ibid.

37 Anyone who failed to produce an ID card, work document, and a document of residence could be classified as unproductive and sent to the rural areas as part of the program. It was very difficult to appeal these decisions. The program received a great deal of criticism for human rights abuses. According to Machava, at the height of Operação Produção, the numbers of people sent for reeducation rose to ten times that of all previous campaigns combined. Machava, "The Morality of Revolution."

38 In 1978, 16 percent of the population of Niassa lived in communal villages. In Cabo Delgado, the rate was much higher at 88 percent. Manuel G. M. De Araújo, "Communal Villages and the Distribution of the Rural Population in the People's Republic of Mozambique," in Population and Development Projects in Africa, eds. John I. Clarke et al. (Cambridge: Cambridge University Press, 1985), 153-163. See also Merle L. Bowen, The State Against the Peasantry (London: University Press of Virginia, 2000), 12.

39 See also "Familiares de ex-reeducandos brevemente no Niassa," Notícias (Maputo), December 17, 1981, accessed March 26, 2016, www.mozambiquehistory.net/justice/ reeducation/19800814_familias_no_niassa.pdf.

40 See "Niassa: aqui começa Moçambique novo," O Jornal (Lisbon), October 7, 1983, accessed March 26, 2016, www.mozambiquehistory.net/history/operacao_producao/ 19831007_niassa_is_new_mozambique.pdf; B. Mavanga, "Nos ex-centros de reeducação, trezentos lares reconstruídos no Niassa," Notícias (Maputo), June 11, 1982, accessed March 26, 2016, www.mozambiquehistory.net/justice/reeducation/19820611_ex-cen tros_de_reeducacao.pdf.

41 Ibid. Interview with Omadi Dawadi, Sanga district, February 14, 2013.

42 Galli, Peoples' Spaces, 40. According to Ce-Omadi, it had been funded by the Chinese.

43 See also Galli, Peoples' Spaces, 46.

44 The 3,000-hectare Matama State Farm that was established in 1976 was regarded a "model farm in the area." Out of its 1,900 workers, 100 were women. See Urdang, And Still They Dance, 106-108, 194.

45 In many places, Frelimo's program was very unpopular with the rural population. Sérgio Chichava writes that FRELIMO largely failed to implement its villagization program in Zambezia due to the population's strong resistance. Sérgio Chichava, “They Can Kill Us but We Won't Go to the Communal Villages!' Peasants and the Policy of 'Socialisation of the Countryside' in Zambezia," Kronos 39, no. 1 (2013): 112-130. See also M. Anne Pitcher, "Disruption without Transformation: Agrarian Relations and Livelihoods in Nampula Province, Mozambique 1975," Journal of Southern African Studies 24, no. 1 (1998): 116, 124.

46 See "Centro de reeducação de Msauíze"; Cabrita, Mozambique; Jenkins, "Image of the City," 116-117. In his study, "The Morality of Revolution," Machava effectively shows how the reeducation camps were "spaces of social abandonment."

47 Interview with Lúcia Ali Abdala, Sanga district, July 19, 2013.

48 In the late 1980s, Mozambique scholars highly contested the idea of the war as a destabilization war. Christian Geffray was one of the first scholars to put forth the idea that RENAMO also had local support among the rural population. He argued that the war had transformed into something that could no longer be neatly classified as a "destabilization war." Christian Geffray, A causa das armas: antropologia da guerra contemporânea em Moçambique, trans. Adelaide Odete Ferreira (Porto: Ed. Afrontamento, 1991). Since the mid-90s, most scholars have argued for an understanding of the complex dynamics of the war, the interplay of both internal and external factors. See, e.g., Adam, "Trick or 
Treat”; Chichava, “"They Can Kill Us”; Dinerman, Revolution, Counter-Revolution and Revisionism; Lubkemann, Culture in Chaos; Schafer, Soldiers at Peace.

49 Interview with Lúcia Ali Abdala, Sanga district, July 19, 2013.

50 Arnold Berleant, Sensibility and Sense: The Aesthetic Transformation of the Human World (Exeter: Imprint Academic, 2010), 145.

51 Berleant, Living in the Landscape, 20.

52 Ibid., 15.

53 Interview with Lúcia Ali Abdala, Sanga district, July 19, 2013.

54 Ibid.

55 David Harvey, Social Justice and the City (Baltimore, MD: The Johns Hopkins University Press, 1973), 23-24; David Harvey, "The Sociological and Geographical Imaginations," International Journal of Politics, Culture \& Society 18, no. $3 / 4$ (2005): 211-255.

56 James Ferguson, Expectations of Modernity: Myths and Meanings of Urban Life on the Zambian Copperbelt (Berkeley: University of California Press, 1999), 13.

57 During a previous session, I had taken several photos of Lúcia, which I gave to her during this meeting. I asked her what she thought of the pictures and if she wanted me to take other pictures. This was a process that I repeated with all the DFs. The conversations about these pictures also gave me valuable insight into the DFs' body perceptions. Sometimes, the DFs spoke admiringly of their body posture that they claimed showed their soldier history. Other times, they lamented that they looked worried and tense in the pictures. Many wanted a picture of themselves sitting down; this posture, as they argued, showed the body at ease, relaxed.

58 Here the argument follows Berleant's claim that while the aesthetic is always part of the experience, it is not always the dominant value. See also Berleant, Living in the Landscape, 62; Aesthetics and Environment (Burlington, VT: Ashgate, 2005), 154-155.

59 Berleant, Living in the Landscape, 24. On social aesthetics see also Berleant, Aesthetics and Environment, 154.

60 Interview with Lúcia Ali Abdala, Sanga district, July 19, 2013.

61 Interview with Lúcia Ali Abdala, Sanga district, May 30, 2013.

62 Here I am also influenced by Tim Ingold's notion of "dwelling," which he develops drawing on Merleau-Ponty's phenomenology of perception, the writings of ecological psychologist James Gibson, and Heidegger. In his work, dwelling signifies the "active engagement" that the subject has "with the constituents of his or her surroundings." Through dwelling, as he writes, the individual is involved in relationships with human and nonhuman beings. Ingold, Perception of the Environment, 5 .

63 Berleant, Sensibility and Sense, 204.

64 Arnfred,"Women in Mozambique," 7.

65 Interview with Maria Ajaba, Lichinga, June 19, 2014.

66 See Katto, "Emotions in Protest."

67 See also Jason Sumich, “'An Imaginary Nation' Nationalism, Ideology \& the Mozambican National Elite," in Sure Road? Nationalisms in Angola, Guinea-Bissau and Mozambique, ed. Eric Morier-Genoud (Leiden: Brill, 2012).

68 Berleant, Living in the Landscape, 100.

69 Interview with Rosa Chalamanda, Mavago district, August 6, 2013.

70 Lefebvre, Rhythmanalysis, 8.

71 On Lefebvre's notion of eurhythmia, see Rhythmanalysis, 67-69.

72 Ibid., 21.

73 Interview with Rosa Saide, Lichinga, June 19, 2013.

74 Both words have the meaning of dirty/ugly/bad. They not only describe the exterior appearance but also the negative feelings that become associated with such places. A place that is described as dirty/ugly/bad is also a place where a person does not feel good.

75 Interview with Adiana Matola, Muembe district, June 11, 2013.

76 Interview with Madalena Bitete, Lago district, August 13, 2013.

77 Economist Intelligence Unit (EIU), Country Report: Mozambique (London: Economist Intelligence Unit, 2015). 
78 Homi Bhabha, "DissemiNation: Time, Narrative, and the Margins of the Modern Nation," in Nation and Narration, ed. Homi Bhabha (London: Routledge, 1990), 302.

79 Interview with Celina Saide, Mavago district, August 7, 2013.

80 See also Emily Brady, "The Sublime, Ugliness and Terrible Beauty in Icelandic Landscapes," in Conversations with Landscape, eds. Karl Benediktsson and Katrín Anna Lund (Aldershot: Ashgate, 2010), 125-136.

81 Interview with Rosa Chalamanda, Mavago district, August 6, 2013.

82 Lefebvre, Rhythmanalysis, 10, 89.

83 Modernization has unequally effected men and women. See also Arnfred, "Women in Mozambique," 11-12; Arnfred, Sexuality and Gender, 39-61.

84 Robin James Smith and Kevin Hetherington, "Urban Rhythms: Mobilities, Space and Interaction in the Contemporary City," The Sociological Review 61, no. S1 (2013): 5-6.

85 dos Santos, Desconhecido Niassa, 159-165. See also Alexandre António and Lúcia Laurentina Omar, Cidade de Lichinga (Maputo: ARPAC, 2000).

86 INE, Estatísticas do distrito de cidade de Lichinga 2013 (Maputo: INE, 2013); Município de Lichinga, Conselho Municipal da Lichinga, "Perfil do Município de Lichinga," Lichinga, 2011. When Lichinga was elevated to the category of city it only had a population of almost 4,000 people. After independence, its population has grown rapidly, especially as a result of the civil war as well as "Operação Produção." António and Omar, Cidade de Lichinga, 59.

87 On African cities, see, e.g., Hans Peter Hahn and Kristin Kastner, Urban Life-Worlds in Motion: African Perspectives (Bielefeld: Transcript Verlag, 2012); AbdouMaliq Simone, For the City Yet to Come: Changing African Life in Four Cities (London: Duke University Press, 2004); Sarah Nuttall and Achille Mbembe, eds., Johannesburg: The Elusive Metropolis (Durham: Duke University Press, 2008).

88 Bhabha, "DissemiNation." As he argues, the singular time of the state is disrupted by the time of the people.

89 Interview with Helena Caisse, Sanga district, July 21, 2013.

90 Município de Lichinga, "Perfil do Município."

91 Interview with Maria Ajaba, Lichinga, June 19, 2014.

92 Yrjö Sepänmaa, "Face to Face with the Landscape," in Koht ja Paik/Place and Location, eds. Kaia Lehari and Virve Sarapik (Tallinn: Proceedings of the Estonian Academy of Arts 8, 2000), 13.

93 Interview with Mwemedi N'tawula, Mavago district, August 9, 2013.

94 On FRELIMO's international support during the liberation struggle, see, e.g., Dalila Cabrita Mateus, A luta pela independência: a formação das elites fundadores da FRELIMO, MPLA e PAIGC (Mem Martins: Inquérito, 2006), 127-130; Cabaço, Moçambique, 292; Tor Sellström, Sweden and National Liberation in Southern Africa Vol. 2: Solidarity and Assistance 1970-1994 (Uppsala: The Nordic Africa Institute, 2002).

95 Comprising over 30 percent of Niassa's total territory, the Niassa National Reserve is about twice as big as Kruger National Park in South Africa. Due to its remoteness, it is an exclusive holiday destination, and visitors are often flown in by plane.

96 As Elísio Macamo argues, the notion of "modern" in African has been shaped by both colonial and various post-colonial ideals; more importantly, people negotiate its various meanings through their social lives. "Negotiating Modernity: From Colonialism to Globalization," in Negotiating Modernity: Africa's Ambivalent Experience, ed. Elísio Salvado Macamo (Dakar: Codesria, 2005), 1-16. See also e.g. Jan-Georg Deutsch et al., African Modernities: Entangled Meanings in Current Debate (Oxford: James Currey, 2001); Barbara Meier and Arne S. Steinforth, eds., Spirits in Politics: Uncertainties of Power and Healing in African Societies (Frankfurt: Campus Verlag, 2013); Charles Piot, Remotely Global: Village Modernity in West Africa (Chicago: University of Chicago Press, 1999).

97 Lefebvre, Rhythmanalysis.

98 EIU, Country Report.

99 See, e.g., Joseph Hanlon and Teresa Smart, Há mais bicicletas—mas há desenvolvimento? (Maputo: Promedia, 2008). 
100 Interview with Rosa Mustaffa, Muembe district, June 12, 2013.

101 Interview with Helena Baide, Lichinga, May 23, 2014.

102 Ibid.

103 "Guebuza deixa promessas de melhorar a rede rodoviária," O País (Maputo), March 24, 2014, accessed March 26, 2016, http://opais.sapo.mz/index.php/component/content/ article/63-politica/29191-guebuza-deixa-promessas-de-melhorar-a-rede-rodoviaria-.html.

104 Município de Lichinga, "Perfil do Município." The train tracks between Lichinga and Cuamba were destroyed during the civil war and only rehabilitated in 2016.

105 Interview with Rosa Namate, Macaloge, May 30, 2013.

106 The improved houses in the countryside are quite basic. They are made of clay bricks and have zinc roofing. Usually, they have packed earth floors. The houses have no running water or electricity. The sizes of the houses vary, but they tend to be quite small. In my interviews, those DFs who had more grandchildren spoke of wanting to have bigger houses with more rooms, while those who had fewer spoke of requiring less space.

107 See Sara Ahmed, "Multiculturalism and the Promise of Happiness," New Formations 63 (2007/2008): 133. Negative difference of this kind, as Noel Castree argues, is crucial to the operation of the capitalist system; it both functions through it and creates it. "The Spatio-Temporality of Capitalism," Time E Society 18, no. 1 (2009): 53.

108 Social aesthetics refers to the aesthetics of social situations and human relationships. Berleant, Aesthetics and Environment, 154.

109 Interview with Rosa Mustaffa, Muembe district, June 12, 2013.

110 Many ex-combatants I interviewed believed that serious illness or death in their families had been caused by their jealous neighbors. See Victor Igreja on the linkages between spirits and illnesses in people's belief systems in Mozambique. "Legacies of War, Healing, Justice, and Social Transformation in Mozambique," in Psychosocial Perspectives on Peacebuilding, eds. Brandon Hamber and Elizabeth Gallagher (London: Springer 2015), 223-254. See also Bjørn Enge Bertelsen, Violent Becomings: State Formation, Sociality, and Power in Mozambique (New York: Berghahn Books, 2016), 121-159. Bertelsen emphasizes the social and relational aspect of bodily well-being in his examination of spirits and healing practices in Chimoio, central Mozambique.

111 Interview with Rosa Mustaffa, Muembe district, June 12, 2013.

112 Interview with Tito Brás Cassimo, Lichinga, June 19, 2014.

113 Interview with Rosa Salimu, Lichinga, July 4, 2013.

114 Lefebvre, Rhythmanalysis, 67.

115 Tim Edensor, "Introduction: Thinking about Rhythm and Space," in Geographies of Rhythm: Nature, Place, Mobilities and Bodies, ed. Tim Edensor (Burlington, VT: Ashgate, 2010), 3 . 


\section{Home, (be)longing, and the beautiful}

If landscapes are conceptualized as always in the process of becoming, then "home" also becomes a fluid concept. In the previous chapter, I looked at the aesthetics of homeplace and place attachment and the (sensuous) rhythms that constitute the desired body-landscape relationships. Berleant writes that when there is "a certain mutuality, a reciprocity of person and place," it brings us a sense of belonging. ${ }^{1}$ This resonates with Galen A. Johnson's argument that the experience of the beautiful creates a "sense of integration between self and the world." " In this chapter, I will continue to analyze how aesthetic sensibilities influence the negotiation of belonging in the DFs' narratives at the different scales $^{3}$ of body, family, neighborhood, town, province, nation, region, and even the globe.

As I argued in Part II, living in the mato entailed a certain spatial displacement of the body, an experience of not being in one's proper place. "Home" became in many ways an unreachable (even unimaginable) location. Before the war (as, for instance, Helena's narratives in "Living Landscape" show), one's maternal family strongly defined the young girls' sense of homeplace. With the war, family members were forcefully separated from each other, and people were dislocated from their homelands. Guerrilla life introduced new kinds of gendered mobility and a new geography of movement. This movement was, of course, largely governed by coercion. Simultaneously repressive and formative (as we learn from Foucault), ${ }^{4}$ violence intimately shaped the DFs' body-landscape relationship. Emotionally, the removal from one's family is still a painful memory for many. On a physical level, the sensory memories of the forced movement of carrying heavy loads of war material across great distances still linger on one's body. The different modalities of violence (e.g., physical, psychological) cannot, of course, be separated from each other but intertwine. Violence infiltrated the combatants' sensory experiences of the landscape in many ways. Even today, the "bush" continues to be remembered in terms of negative aesthetics. The DFs speak of remembering the smell of blood and ammunition, the noise of helicopters and bombing, the food they had not taste, the feeling of intense hunger in their stomachs, the kinesthetic experience of "running-running" to escape the bombings, and the wetness of the rainy seasons that they had to suffer through without proper shelter. Many DFs compare 
their way of living during the war to that of animals, constantly on the move without a place to call home.

Forced to move around a lot, the DFs often use the verb "visiting" to describe their relation to the different places where they set up camp during the war (see Maria on page 101). Generally, the DFs clearly distinguish between "places of visit/of others" (Portuguese: terra de visita/de outros; Ciyaawo: cilaambo kwa acalendo/ca wane) and "my/our land/zone/village" (Ciyaawo: pamangwetu, Portuguese: minha terra/zona/ aldeia). The notion of "pamangwetu" often connotes a sense of home and belonging. This is evident in phrases such as "cilaambo ca kumangwetu" (home country) and "pamuri pamangwetu" (home village) in which this aspect of spatial attachment is emphasized. The DFs' narratives of the wartime, however, are characterized by a sense of body-landscape disconnection. Fátima, for instance, speaks of her experience of not having her "own place to stay" ("lugar próprio para ficar") during the war. It is notable that "kubase" (military base) and "kumangwetu" (home) are not usually associated with each other in the interview talk. For instance, the concept "kubase ja kumangwetu" ("my/our home base") was only used once by Helena in an interview question. In the areas where my interviewees lived, the war lasted nine years, from 1965 to 1974. The intensity of the bombings and war effort varied through these years, and the war affected the different areas unevenly. In some places, as my interviewees said, they experienced quieter times in which the bases even started to feel like "home." Maria Yassine, for instance, spoke of a time when she felt "like at the village again" ("mpela kumuri roni"). ${ }^{5}$ This points to experiences of the positive aesthetics and rhythmicity of the place that evoked memories of village life before the war. Also, Maria Mota remembered a time during the war when the population had been allowed to perform siyala, an important soundmark of community life at peacetime, and a meaningful acoustic feature in the yearly religious cycle of the Muslim Ayaawo. Maria talks of how this influenced her relationship to the landscape. "[N]ow we are from right here" ("uweji rano ni wa muno-muno"), she remembers thinking. Even today, she remembers that place fondly: "Iih! That place [Base N'sawisi] is home. That place was home" ("Iih! Kwele ni kumuri. Kwele kumuri kwadiji.").

The notion "kumangwetu" extends socio-spatial belonging beyond that of the individual and their family. It locates the individual within the family and the family within the village (/zone/homeland). For instance, though a good house (Ciyaawo: nyumba) is believed to go a long way in enabling a good life, in itself the house and the social world it makes space for does not account for home. As Helena's narratives in "Living Landscape" show, before the war, the young DFs' sense of homeplace was strongly linked to their families and home villages. Their sense of homeplace was significantly expanded through the experience of soldiering and the new political discourse that introduced new notions of socio-spatial belonging. For instance, the notion "cilaambo ca kumangwetu" (though not very commonly used) speaks of this extended meaning of home. Even so, home has multiple meanings. As I argue, the DFs' experience of spatial mobility and immobility importantly continues to shape 
their sense of belonging at the different scales. After the war, as I showed in "Living Landscape" most DFs have led quite mobile lives, and multiple places across the region (and for some, the country) have shaped their life trajectories and landscape experiences. This movement has not only been guided by one's personal decisions and desires. In the first years of independence, the army determined the sphere of movement for many. During the civil war, some of my interviewees spoke of having to abandon their homes and villages and relocate because of their fear of the RENAMO troops operating in the area. Marriage also affected DFs' movement patterns. Some, like Lúcia, followed the practice of living close to her maternal kin. Other DFs pursued their military husbands as they were transferred across the country. Many of these women, however, later returned to Niassa. Often, this movement is narrated as a return home from the land of others ("terra dos outros"). Rosa Mustaffa, for instance, followed her ex-combatant husband to Nampula. After living there for many years, she left her husband, took her children, and returned to Niassa. Next, Rosa speaks of her experience:

ROSA: So ... that way of DRINKING ... I no longer ... the life no longer ... no longer was good. As a person ... who went to the homeland of others, when the life isn't good ... the person thinks about returning. I RETURNED alone. He didn't accompany me. [laughs lightly] I returned alone . . . and I left him there.... I returned. “ih, I already know the way.” And I followed the trail .... and I returned.

HELENA: Members of Female Detachment are no good ... it's enough [laughs lightly as she speaks:] to feel bad ... that's it, packing.

ROSA: No way! Suffering when you know that [laughs out loud as she speaks:] I have [means]. I will leave.

HELENA: $\underline{\mathrm{Ah}}$, no, I don't want. [ROSA: Eeh.] He will enslave me there, I don't know what-

ROSA: Hmm, I returned alone, aah-

HELENA: I fought. I fought to defend ... my life. Now, another person arrives to cause me trouble. Aah, I will go where I want-

ROSA: But first I RETURNED. I had a child - my youngest child, I carried on my back and I returned. After that I went ... FOUR trips ... to go and collect my children.

JONNA: Aah, was it difficult?

ROSA: SO THE CHILDREN I GOT BACK. They all arrived here. Then they started ... to say that they can't handle the life here. ${ }^{7}$

This excerpt shows a very different kind of experience of the landscape compared to the DFs' narratives about the wartime. Rosa speaks of knowing how to navigate the landscape and knowing where to find home, even when she is in the "homeland of others." As she narrates, "I RETURNED alone. He didn't accompany me. I returned alone . . . and I left him there. . . . I returned. 'ihh, I already know the way.' And I followed the trail ... and I returned.” Rosa makes 
it clear that she had only moved to Nampula because of her husband, and when she experienced being strongly unhappy in the marriage, she returned to Niassa. Her veteran's pension enabled her to make this decision. Her resolution was also aided by the fact that, according to matrilineal practices, it was within her rights to take her children with her. Although when they arrived in Niassa, her children did not want to stay. According to Rosa, they "weren't used to life here." Gustatory perception often plays an important role when DFs speak of their experiences of visiting or living in "other" places away from Niassa. As Rosa argues, her children were used to eating (fresh) fish, different type of beans, and ugadi made of manioc (instead of maize). They moved back to Nampula and only come to visit her in Muembe, Niassa. Rosa also speaks of her own experience of living in Nampula. It always takes some getting used to, she argues, "when a person is somewhere that is not her home [terra dela]." Niassa, as I have argued, is an important landscape of belonging for the DFs. Most importantly, this sense of belonging is tied to one's desire to be close to one's family. Many of the DFs have occupied the social position of the female elder of their extended families. They are the ones who other family members come to for support. As the DFs are relatively mobile, the whole of the province of Niassa is considered one's homeland. Those who have family living in different places can visit them rather easily. Often, their families no longer live in the same places where the DFs grew up before the war, and thus the DFs have a weak sense of attachment to these new "family villages."

Negotiating one's relationship and belonging to landscape is a gendered practice, as Rosa's and Helena's exchange explicates. Rosa's emphasis on the fact that she "returned alone" speaks a lot about female gendered mobility. It suggests that this level of mobility is not something that one can take for granted. Movement patterns tell a great deal about power and control. ${ }^{8}$ Yet, as Helena argues, "the members of the female detachment are no good." They follow their feelings ("it's enough to feel bad ... that's it, packing"). Helena's speech points to the perceived subversiveness of the DFs' actions. Still, as Rosa's words indicate, DFs have more freedom of movement because of the veteran's pension. Their sense of spatial mobility has changed through the years. As young women after the war, the DFs generally adjusted their movements to that of their husbands. The political discourse on the nuclear family and the leading role assigned to the man as head of the family functioned in disciplining their bodies into their new roles as wives. In this new family model, women's social position was actually weakened. ${ }^{9}$ However, it is important to note that matrilineal traditions and Yaawo cultural models of womanhood continued to coexist alongside socialist models. For instance, though officially divorce was frowned upon, following matrilineal practices, women (as well as men) were considered free to leave a marriage that was not working for the benefit of both. The children belonged to the woman's family, and thus, for instance, Rosa managed to take all her children to Niassa (although they later returned to Nampula). Arguably, however, divorce for women has become more difficult due to the changing economic structure of society as well as the neolocal living arrangements. Many women 
feel economically tied to their husbands. ${ }^{10}$ For Rosa, her veteran's pension enabled her to "leave alone" and find her own way back to Niassa. Gender, age, and their social and economic position as veterans crucially shape the DFs' sense of spatial mobility and thus their landscape relationship.

On the one hand, Mozambique is perceived to have shrunk in size as the DFs' sense of distance and mobility has changed (for instance, Rosa made four trips to Nampula to get her children). On the other hand, the grandness and vastness of Mozambique was often commented upon in the interviews. Next, Fátima Buanande speaks of her perception of the changing landscape of Mozambique:

MOZAMBIQUE is big. Mozambique is a big country. BECAUSE it's like this ... long time ago people went to JOYINI [Johannesburg]. They went to Malawi. Now we have Joyini here. We have Malawi here. THEY USED TO GO to Tanzania ... to work. Now Tanzania is here. We are starting to get mattresses, houses with zinc roofs. EVEN THE GOVERNMENT can give loans to children, to the youth. Those youths they are building houses with zinc roofs. They are developing/advancing. Mozambique is big, yes. ${ }^{11}$

Mozambique does not appear a very meaningful spatial construct in the stories that the DFs remember being told by their parents and grandparents. In colonial times, people's movements no way centered on Mozambique. Due to Portugal's lack of investment as well as its repressive politics, Mozambique was very strongly marginalized in the world economy. Men traveled long distances to neighboring countries to seek work in order to pay the taxes and make a living for their families. Things have changed with independence. Fátima's perception is that as an independent country, all those economic forces now operate within Mozambique, and Mozambique is thus fused within the regional (if not global) landscape. As she describes, now a person does not have to travel to Tanzania to make money or to buy basic necessities. These days, Mozambique centers people's movements; in this sense, it is perceived as what Cahen refers to as a unified space. ${ }^{12}$ Moreover, it is big because it encompasses a world of movement. Even Niassa holds within itself this potential, as Fátima continues:

A long time ago we took that thing ... those things here ... that thing ... TOBACCO up to Ciwambo sleeping 20 nights. But now Ciwambo is here. SUGAR, when you want tea. You want mattresses, you buy. But now it's better ... to farm. ... After getting the produce from your machamba, with the six thousand meticais, you buy that, you buy that- the youth. ${ }^{13}$

During colonial times, Ciwambo in the area of Quelimane on the coast of the Indian Ocean was for many in Niassa the most significant travel destination within the territory of Mozambique. Yaawo men used to grow tobacco to sell at Ciwambo. They traveled in caravans, and many stories spoke of the dangers and hardships of these trips that lasted several months. "But now," as Fátima argues, "Ciwambo is here." It is a great sign of "progress," in her view, 
that most things are now available in Niassa. One is not forced to travel but can choose to stay. While Fátima mostly speaks of discontinuities between colonial and postcolonial spatial practices, she insists on the continued importance of farming. Farming plays an important role in the DFs' desired bodylandscape relationship and connects the DFs to Niassa (which they perceive to hold great potential for agricultural production). The difference these days in comparison to the past is that there are markets for agricultural produce in Niassa. Fátima argues that by farming land, young people can earn money and thus participate in the new national consumerist modernity. The DFs' narratives suggest a strong sense of attachment to Niassa. But while the DFs choose to stay in Niassa, they speak of their wish of having the world come to them-that is, of having Niassa encompassed within a new urbanized rhythmicity.

Yet what is Fátima's and the other DFs' personal sense of belonging to these vast landscapes of Mozambique? Cahen makes the important point that identifying oneself as a "member of a country," in this case as "Mozambican," does not automatically link to a sense of "national belonging."14 This is not a causal relationship; instead, I suggest we need to analyze the different spatial scales of identification and loyalty. What stands out in Fátima's description of the "great country of Mozambique" is that it holds promise for the youth, who are already involved in shaping its future trajectory. In this sense, Mozambique belongs to the young people, not the elderly ex-combatants. The ex-combatants' ideas about their own future trajectories are rather pessimistic and even imbued with melancholia. Though they express belief in Frelimo's ability to modernize the country, it is a future that no longer includes them. As Maria Ajaba argues, taking measure of her "movements these days," she cannot anticipate that all her dreams will be fulfilled. Amina Ndaala's words also resonate this sentiment: "If it were that I had movement, there are many things I would like to have" ("Kuwaga kuti nakwete muvimentu, yejinji ya nayirakaga"). ${ }^{15}$ The ex-combatants' personal relationships to Mozambique cannot be described only through the aesthetics of the beautiful. The ex-combatants express varying degrees and intensities of hope for a more fulfilling relationship of sociospatial belonging. Hope and disappointment are important notions to look into in order to understand the ex-combatants' sense of national belonging. "Can hope be disappointed?" asks Ernst Bloch in an intriguing essay. As he ends up arguing, hope is

something that does not, in spite of all, make peace with the existing world. Therefore hope must be unconditionally disappointable, first, because it is open in a forward direction, in a future-orientated direction; it does not address itself to that which already exists. ${ }^{16}$

Bloch, moreover, makes the distinction between the hope of daydreams and well-founded hope. As we looked at in the previous chapter, the ex-combatants tend to remember the first years of state socialism nostalgically. In their narratives, 
those years of "well-founded hope" are juxtaposed with today's "hope of daydreams." While some are able to negotiate a sense of hope (be it a hope of daydreams; see, e.g., Maria Ajaba page 208), the continued history of intimately felt disappointment leads others to distance themselves from the party-nation, seeking other forms of socio-spatial attachment. Helena's narratives in which she expresses her desire for a different body-landscape relationship explicates this type of movement. Moreover, during my fieldwork, some DFs I interviewed told me about other female ex-combatants they knew who-in search for more positive socio-spatial identifications - had moved out of their villages to live the "life of the machambas."

Finally, I suggest that belonging is best conceived of as a relational notion. Belonging is never solely a subjective experience; it is both subjective and objective. This means that belonging is never a one-sided engagement. Rather, our sense of belonging is shaped and negotiated in a reciprocal relationship between body and world. Moreover, as I suggest, in the DFs' narratives, belonging stands out as a negotiation for a relationship of peaceful dwelling with the landscape. Belonging, as also Berleant points out, goes beyond emotional attachment. ${ }^{17}$ As I discussed in Part II, emotions are intertwined with the sensory experiences of our body histories; they cannot be separated from each other. On the scale of the body, "peaceful dwelling" involves negotiations over corporeal well-being. The body is "a bundle of rhythms," as Lefebvre writes. The eurhythmic harmony of these rhythms is a sign of a healthy body. ${ }^{18}$ Yet the ex-combatants' narratives speak of experiences of bodily arrhythmia (the experience of tension, of a heart beating too fast). Many ex-combatants spoke of how war memories manifest themselves as physically felt disturbances in their bodies. When arrhythmia prolongs, it results in illness, to which talk about "going crazy" attests. As I have shown, this sense of peaceful dwelling with one's body is something that the DFs continuously negotiate. Moreover, as the body is intimately engaged in a lived relationship with the world, "peaceful dwelling" is simultaneously negotiated at different scales: body, nation, ex-combatant community, village/town, neighborhood, and province. ${ }^{19}$ For instance, "failed" negotiations on one scale can have a negative effect on another scale; as I argued in the previous chapter, social arrhythmia can also manifest itself as a bodily illness. Many DFs expressed difficulties in dwelling peacefully with their neighbors and village communities; they feel unliked, as Rosa Mustaffa argues. Thus even their belonging to Niassa is a relationship that requires continuous negotiation at multiple scales. Though I argue that these negotiations are reciprocal, I do not mean to imply that they are egalitarian. Rather, they are shaped by unequal power relations; moreover, discrimination, exclusion, and oppression are also part of these processes. As the DFs' narratives show, "belonging" is often not experienced as a completely fulfilled relationship on all scales. This sense of partial belonging leaves one with a longing to belong more closely and intimately. It is this sense of partial fulfillment that I suggest characterizes the DFs' sense of national belonging. 


\section{Notes}

1 Berleant, Living in the Landscape, 109.

2 Johnson, Retrieval of the Beautiful, 12.

3 Human geographers have increasingly focused on the multiscalarity of "home." See, e.g., Alison Blunt and Robyn Dowling, Home (London: Routledge, 2006).

4 Michel Foucault, Discipline and Punish: The Birth of the Prison, trans. Alan Sheridan (New York: Vintage Books, [1975] 1995).

5 Interview with Maria Yassine, Lichinga, March 25, 2013.

6 Interview with Maria Mota, August 21,2013, Lichinga. Often, "kumuri," which signifies "village," is used to denote "home."

7 Interview with Rosa Mustaffa, Muembe district, June 12, 2013.

8 See also Mike Crang, "Urban Morphology and the Shaping of the Transmissible City," City 4, no. 3 (2000): 306.

9 See also Arnfred, "Women in Mozambique," 9-10.

10 Carla Braga's research also points to how the state's development projects implicitly endorse patriliny, which has contributed to the erosion of women's gender power in matrilineal societies. “'They Are Squeezing Us!' Matrilineal Kinship, Power and Agricultural Policies: Case Study of Issa Malanga, Niassa Province," in Strategic Women, Gainful Men: Gender, Land and Natural Resources in Different Rural Contexts in Mozambique, eds. Rachel Waterhouse and Carin Vijfhuizen (Maputo: UEM; ActionAid-Mozambique, 2001), 199-225. See also Pitcher, "Conflict and Cooperation."

11 Interview with Fátima Buanade, Muembe district, June 14, 2013.

12 See Cahen, "Anticolonialism \& Nationalism," 9.

13 Interview with Fátima Buanade, Muembe district, June 14, 2013.

14 Cahen, "Anticolonialism \& Nationalism," 22.

15 Interview with Amina Ndaala, Lichinga, June 23, 2014.

16 Ernst Bloch, "Can Hope Be Disappointed?" in Literary Essays, trans. Andrew Joron and others (Stanford: Stanford University Press, 1998), 341.

17 Berleant, Living in the Landscape, 109.

18 Lefebvre, Rhythmanalysis, 20.

19 Moreover, these "geographical scales" cannot be neatly separated; as Doreen Massey writes, they "constitute each other." Massey, Space, Place, and Gender, 161. 


\title{
Epilogue
}

\section{Spatial movements, relations, and representations}

\begin{abstract}
"She came from far away to write about the history of the DF!" Helena often enthusiastically explained as she introduced me to other female ex-combatants. Her words evoke our research relationship as an encounter between "here" and "far," not a static relationship but one of movement. She calls it forth as a positive coming together that generates a global sense of space. Helena's enthusiasm is catching, and the spatial imagery of her words prove captivating. The women generally appeared animated by the prospect that their history as "the women who fought in Mozambique's liberation struggle" might reach audiences beyond the national boundaries.

This study has been in many ways an engagement in negotiating and making sense of the "in-betweens": on the one hand, the space between near and far (or proximity and distance) in the research relationships, and on the other hand, the relation between material lives and abstract theory in the writing of this academic text. The spatial relations of the research encounters are, of course, far more complex than what immediately comes across in Helena's words. I still vividly recall my own feelings of helpless disconnection during my first meeting with female ex-combatants in the village of Nzizi in Muembe. This was my first experience interviewing DFs in Ciyaawo and in the countryside outside of Lichinga. I had built up my own expectations of how I wanted to conduct the interviews and the kind of research relationships I wanted to cultivate. Arriving in Nzizi in the late morning, I was met by a group of about ten female ex-combatants (later only two of them turned out to be DFs) who Mr. Docotal, the ACLLN representative of the locality, had gathered together in the classroom of the local primary school for me to interview. Conducting the first interviews under the watchful eye of this elderly ACLLN officer, and with the fumbling translation help of his young male relative, I seriously wondered if my research made any sense at all. My bodily experience at that moment was that I had indeed come from very "far," and with the language barrier and hierarchical layers of gatekeeping, I felt out of place and out of touch with the people with whom I was supposed to build rapport. I remember thinking, "How could I possibly ask these people to share their personal life memories with me?" Even the ACLLN representative lost interest in us, napping while we stumbled through the interviews.
\end{abstract}


The research process continuously forced me to negotiate my space as a researcher and my relationship to the different landscapes of my research. Some negotiations proved more difficult than others, and all did not end the way I desired. In Nzizi, despite the awkwardness of the first encounter, fortunately, the DFs were willing to give the interviews another attempt. By the next time (which was three months later), Helena and I had already gained more experience working together. We had become more seasoned co-interviewers. This time, we met the DFs at their homes in a more informal atmosphere without the presence of the ACLLN representative. The women clearly seemed more at ease and no longer shy, also in turn asking questions about me and my home country. The life narratives that have been the focus of this study were shaped in such embodied encounters and negotiations. I forged closer relationships with some DFs while remaining more distant with others. Helena performed an important mediating role in these research relationships. She and I developed a close collegial relationship during the fieldwork. When we were saying our good-byes, Helena suggested that we take one last picture of us together in her yard, seated on chairs facing each other. Such a picture would make a good remembrance, she explained, since this was how we used to sit, often daily, as we discussed our strategies and plans for future work and travels. As Helena liked to say, "No mission can succeed without a proper plan!" I still remember my joy at that moment hearing her words; these are the kinds of face-to-face intersubjective relationships that we as feminist researchers strive after, yet, we never have any guarantee that they will be fulfilled.

Sufficient critical distance and reflexive insight is equally important for research as are the bodily encounters and connections in the field. Yet how does one read and write material lives into relation with abstract theory? Theoretically, my study has sought to problematize the concept of space often reproduced in feminist scholarship on nationalism. I have argued that this notion of space builds on an understanding of a dichotomous relationship between space/ time and male/female. Moreover, space conceptualized as feminine is defined as stasis and in binary opposition to masculine time and history. While these notions often implicitly shape the histories of gendered nationalism that we write, they seldom receive explicit analytical attention. This is the analytical task to which my research has sought to contribute. In my analysis of the DFs' sense of socio-spatial belonging, I have worked on a concept of "lived landscape," which draws both from Doreen Massey's theorization of space and the notion of the lived gendered body in feminist phenomenology. Following Massey, it emphasizes the inseparability of space-time and the openness, multiplicity, relationality, and continuous becoming of space. Drawing on phenomenology, it highlights an idea of the nondualistic relationship between body and landscape. Moreover, Henri Lefebvre's notion of representational space contributes to an understanding of "lived landscape" as the co-constitution of the conceptual and the concrete, sensual, and intimate lived space. As a concept, "lived landscape" allows us to look beyond teleological narratives of "liberation" (/ "oppression") and explore the women's life trajectories as nonlinear spatial histories. Thus 
through a conceptual focus on space, my study contributes to a different kind of gendered history of the liberation struggle.

This book is essentially a history of the lived gendered landscapes of aging female ex-guerrilla fighters in northern Niassa. It is about their bodily negotiations for socio-spatial belonging. In this study, I have focused on the liberation struggle as a particular "historical moment of contestation and change" in people's landscape perceptions and conceptualizations, as well as body-landscape relations in northern Mozambique. Alongside landscape, the "body" has been a central category of analysis for me. Initially, for me, it was the ex-combatants' talk about negative bodily feelings and emotions, as well as expressions about the experiential meaning of politics, that made the "body" (and the body histories of the female ex-combatants) a central focus of my research. This analytical perspective is also important considering how little attention the "body" has received in the study of war memories/histories or the study of the political field. Moreover, in this study, I have sought to explore the ways that discourse and the material practices of the body (and space) intersect. I became motivated to study this through my empirical material, which I read conjointly with feminist scholarship on the concept of the body. In FRELIMO nationalist discourse, the war is hailed as a "revolutionary experience" that transforms (abstract) political notions (e.g., the new gendered language of socio-spatial belonging) into the lived experience of the body. It was this interplay of experience, materiality, and discourse that I wished to study through a feminist theoretical framework. I started with Butlerian social constructivism, gradually finding my way to feminist phenomenology of embodiment. While Butler helped me to analyze the discursive construction of the nationalist identity category "Mozambican woman," it was only through feminist phenomenology that I was able to more closely analyze the "lived body" and, moreover, the ways that bodies resist, and creatively transform their cultural inscription. As my study shows, even today, the DFs continue to negotiate between multiple coexisting body schemas and their different masculine- and feminine-coded ways of being in the world.

The Mozambique that takes shape in the DFs' narratives is both ugly and beautiful. Aesthetic engagement has been a key concept for me, as I have sought to understand the ways that these women negotiate their relationship to the various landscapes that make up their life trajectories. I have especially been interested in interrogating the relationship between personal intimate bodily space and the imagined space of the national. In the DFs' narratives, the "national" often intertwines with the "personal" in a violent relationship. For the excombatants, the "national" is closely associated with FRELIMO, these days the Frelimo state. This relationship carries with it hurtful histories of contact that require constant negotiation in the present. Differently from ex-combatants in the state capital Maputo (especially the nationalist elite), in Niassa, the liberation war does not appear as a nostalgic and distant memory. Rather, it evokes the haptics of the "bush." For many ex-combatants in Niassa, the experience of independence has been tied to a continued experience of violence in the form of socioeconomic and political marginalization. Thus many DFs (as well 
as male ex-combatants) continue to experience that they have not fully escaped the negative aesthetics of the "bush." Aesthetic sensibility, as I argue, is deeply intertwined with experiences of socio-spatial attachment/detachment and influence how belonging is negotiated at different scales (e.g., nation, province, village, family, and globe). Negotiations on one scale affect negotiations on another and cannot be isolated from each other. Moreover, negotiating one's relationship and belonging to landscape is a gendered practice. As I show, gender, age, and their social and economic position as a veteran together crucially shape the DFs' sense of spatial mobility and landscape relationship. The DFs' experience of Mozambique is not only mediated by the spatial politics of Frelimo nationalism, though the category of ex-combatant closely binds them to the state. Lefebvre's notion of "rhythm" has importantly contributed to this analytical project complementing the notion of aesthetic engagement. It allows us to explore the ways that individual and social rhythms intertwine in the materiality of landscape. The violence of nationalism lies in the way that one social group attempts to impose a singular rhythm on landscape. Yet even so-called national landscapes are polyrhythmic landscapes. The Mozambique that emerges from the ex-combatants' narratives is not a homogenous, unified landscape; it is perceived as consisting of multiple and unequal landscapes that are valued according to different scales of beauty.

How does the study of the life memories of female ex-combatants contribute to our understanding of wider cultural landscape histories in northern Mozambique? Female ex-combatants, after all, constitute a small and rather unique social group. Yet, as I have argued in this study, individual embodied memory cannot be separated from social memory. When telling narratives about our lives, we engage with the different cultural scripts available to us. Thus through individual life narratives, one can also learn about the wider spatiotemporal context that shapes those lives. My focus in this study has been on a specific historical moment in the very recent history of Mozambique. A longer time perspective could, of course, give us a more nuanced and deeper understanding of the significance and "change" introduced by this historical moment. For instance, looking at how the landscape of northern Niassa emerges out of the different regionally based oral traditions would broaden our understanding of the changing body-landscape relations of the people in northern Niassa. We could thus also better explore to what extent these older spatial discourses continue to shape people's landscape experiences. The female ex-combatants' life narratives bare traces of older spatial histories. Still, they speak of their relation to those histories as that of discontinuity. My interviewees often spoke of how the war disrupted their childhood and the processes by which these narratives might have been passed on to them. They left home to go to war before growing up. Through the war, their body-landscape relationship was shaped through military practice and FRELIMO nationalism. Some of the DFs learned about their own family histories after the war; others speak of never having asked about this history. Wars disrupt and change the telling of histories of space. Apart from DFs, many chiefs that I encountered also lamented their historical 


\section{Epilogue}

forgetfulness. One chief explicitly argued that his forgetfulness was due to his forced separation (due to war and later Frelimo's socialist spatial politics) from his ancestral lands and spirits. The older histories that I was told by elders in different localities in northern Niassa were abound with stories of great wars and warrior chiefs. The Ayaawo are known to have had powerful female political leaders, yet their histories have largely disappeared from oral tradition. Will the history of the "women who fought to liberate Mozambique" be remembered for generations to come? How will it be remembered? Who will its narrators be? These questions about continuity, discontinuity, and change in spatial histories are also closely linked to questions about the gendered transmission of history.

Finally, to return to Helena's words, the spatial relations of research cannot be romanticized, nor its imbalances of power ignored and glossed over. Thinking space relationally also leads us to think of ethics relationally. This situates ethical action within relationships. It is a question of how to "inhabit the distance between us." In this study, I have discussed these spatial relations as ongoing intersubjective negotiations in which our different subject positions and locations also intertwine. The ethical research relationship is about learning to speak to one another. It is also a relationship in which we are continuously forced to acknowledge the ways that our body spaces and the spaces between our bodies are intimately shaped by ongoing histories of unequal spatial discourses and practices. How then does this text attempt to "inhabit" the space in-between? In my writing, I have sought to bring to the forefront the interactional processes in which knowledge is produced. I have juxtaposed my own analytical text with many long interview excerpts. While my words frame these narratives, the interview excerpts are possible sites of disruption; they can suggest to the attentive reader other meanings and interpretations alongside those I propose. Writing this spatial history of the women who fought in Mozambique's liberation struggle in the northern province of Niassa, I have sought to represent the DFs in a way that does not fix, stabilize, or essentialize them but brings into focus their shifting and multilayered negotiations for personal space and belonging.

\section{Note}

1 Sara Ahmed,“This Other and the Other Others," Economy and Society 31, no. 4 (2002): 569. 


\section{Bibliography}

"23 Mozambican Girls Participate in the Armed Struggle." Mozambican Revolution 21 (September 1965), 7.

Abdallah, Yohannah B. The Yaos: Chiikala cha Wayao. Edited and translated by Meredith Sanderson. 1919. 2nd ed. London: Frank Cass and Company, 1973.

Adam, Yussuf. "Trick or Treat: The Relationship Between Destabilisation, Aid and Government Development Policies in Mozambique 1975-1990.” PhD diss., Roskilde Universitet, 1996.

Adam, Yussuf, and Hilário Dyuti. "O massacre de Mueda: falam testemunhas." Arquivo 14 (1993): 117-128.

Ahmed, Sara. "Creating Disturbance: Feminism, Happiness and Affective Differences." In Working with Affect in Feminist Readings: Disturbing Differences, edited by Marianne Liljeström and Susanna Paasonen, 31-44. London: Routledge, 2010.

Ahmed, Sara. "Multiculturalism and the Promise of Happiness." New Formations 63 (2007/2008): 121-137.

Ahmed, Sara. The Promise of Happiness. Durham, NC: Duke University Press, 2010.

Ahmed, Sara. "This Other and the Other Others." Economy and Society 31, no. 4 (2002): $558-572$.

Aikhenvald, Alexander Y., and Anne Storch. "Linguistic Expression of Perception and Cognition: A Typological Glimpse." In Perception and Cognition in Language and Culture, edited by Alexander Y. Aikhenvald and Anne Storch, 1-45. Leiden: Brill, 2013.

Akawa, Martha. The Gender Politics of the Namibian Liberation Struggle. Basel: Basler Afrika Bibliographien, 2014.

Alcoff, Linda. "Phenomenology, Post-structuralism, and Feminist Theory on the Concept of Experience." In Feminist Phenomenology, edited by Linda Fisher and Lester Embree, 39-56. Dordrecht: Kluwer Academic Publishers, 2000.

Alcoff, Linda. "The Problem of Speaking for Others." Cultural Critique 20 (1991): 5-32.

Allman, Jean, ed. Fashioning Africa: Power and the Politics of Dress. Bloomington: Indiana University Press, 2004.

Alpers, Edward A. "Islam in the Service of Colonialism? Portuguese Strategy during the Armed Liberation Struggle in Mozambique." Lusotopie (1999): 165-184.

Alpers, Edward A. Ivory and Slaves: Changing Pattern of International Trade in East Central Africa to the Later Nineteenth Century. Berkeley: University of California Press, 1975.

Alpers, Edward A. "Towards a History of the Expansion of Islam in East Africa: The Matrilineal Peoples of the Southern Interior." In The Historical Study of African Religion, edited by Terence O. Ranger and Isaria N. Kimambo, 172-201. Ann Arbor, MI: UMI, 1997. 
Alpers, Edward A. "The Yao in Malawi: The Importance of Local Research.” In The Early History of Malawi, edited by Bridglal Pachai, 168-178. London: Longman, 1972.

Alpers, Edward A. "Trade, State and Society among Yao in the Nineteenth Century." Journal of African History 10, no. 3 (1969): 405-420.

Amadiume, Ifi. Male Daughters, Female Husbands: Gender and Sex in African Society. London: Zed Books, 1987.

Amadiume, Ifi. Reinventing Africa: Matriarchy, Religion and Culture. London: Zed Books, 1997.

Amaral, Manuel Gama. O povo Yao: subsídios para o estudo de um povo do noroeste de Moçambique. Tese de Licenciatura em Antropologia, Universidade Técnica de Lisboa, 1968. Lisboa: Instituto de Investigação Científica e Tropical, 1990.

Amin, Ash. "The Good City.” Urban Studies 43, nos. 5-6 (2006): 1009-1023.

Anstey, Simon. "Institutional Change and Community Based Natural Resource Management in Northern Mozambique: The Village Goes Forward: Governance and Natural Resources in North Niassa." PhD diss., University of Zimbabwe, 2009.

António, Alexandre, and Lúcia Laurentina Omar. Alguns usos e costumes matrimoniais dos povos Yao e Nyanja da província do Niassa. Lichinga: CIEDEMA, 2007.

António, Alexandre, and Lúcia Laurentina Omar. Cidade de Lichinga (Maputo: Arquivo do Patrimónia Cultural [ARPAC], 2000).

Araújo, Manuel G. M. de. "Communal Villages and the Distribution of the Rural Population in the People's Republic of Mozambique." In Population and Development Projects in Africa, edited by John I. Clarke, Mustafa Khogali, and Leszek A. Kosinski, 153-163. Cambridge: Cambridge University Press, 1985.

Arnfred, Signe. "Feminism and Gendered Bodies: On Female Initiation Rituals in Northern Mozambique." Quaderns 26 (2010): 61-82.

Arnfred, Signe. "Sex, Food and Female Power: Discussion of Data Material from Northern Mozambique." Sexualities 10, no. 2 (2007): 141-158.

Arnfred, Signe. Sexuality and Gender Politics in Mozambique: Rethinking Gender in Africa. Woolbridge, Suffolk: James Currey, 2011.

Arnfred, Signe. "Women in Mozambique: Gender Struggle and Gender Politics." Review of African Political Economy 15, no. 40 (1988): 5-16.

Arthur, Marie José. "Mozambique: Women in the Armed Struggle." In Gender in Southern Africa in Transition: A Gendered Perspective, edited by Patricia McFadden, 67-82. Harare: SAPES Books, 1998.

Avotri, Joyce Yaa. “'Thinking too Much' and 'Worrying too Much': Ghanian Women's Accounts of Their Health Problems.” PhD diss., McMaster University, 1997.

Bachelard, Gaston. The Poetics of Space. Translated from French by Maria Jolas. Boston: Beacon Press, 1994. Originally published as La poétique de l'espace (Paris: Presses universitaires de France, 1958).

Bagnol, Brigitte. "Female Initiation Rituals and Sexualities." In The Essential Handbook of Women's Sexuality: Meanings, Development, and Worldwide Views, edited by Donna Castañeda, 143-165. Vol. 1. Oxford: Praeger, 2013.

Bakare-Yusuf, Bibi. "Thinking with Pleasure: Danger, Sexuality and Agency." In Women, Sexuality and the Political Power of Pleasure, edited by Susie Jolly, Andrea Cornwall, and Kate Hawkins, 28-41. London: Zed Books, 2013.

Bakare-Yusuf, Bibi. “'Yorubas Don't Do Gender': A Critical Review of Oyeronke Oyewumi's The Invention of Women: Making an African Sense of Western African Discourses." In African Gender Scholarship: Concepts, Methodologies and Paradigms, edited by Signe Arnfred, Bibi Bakare-Yusuf, Edward Waswa Kisiang'ani, Desiree Lewis, Oyèrónké Oyěwùmí, 
and Filomina Chioma Steady, 61-81. Dakar, Senegal: Council for the Development of Social Science Research in Africa, 2004.

Baker, Carolyn D. "Locating Culture in Action: Membership Categorisation in Texts and Talk." In Culture \& Text: Discourse and Methodology in Social Research and Cultural Studies, edited by Alison Lee and Cate Poynton, 99-113. Oxford: Rowman \& Littlefield Publishers, 2000.

Baker, Carolyn D. "Membership Categorization and Interview Accounts." In Qualitative Research: Theory, Method and Practice, edited by David Silverman, 162-176. London: Sage, 2004.

Bamberg, Michael. "Biographic-Narrative Research, Quo Vadis? A Critical Review of 'Big Stories' from the Perspective of 'Small Stories'” In Narrative, Memory and Knowledge: Representations, Aesthetics and Contexts, edited by Kate Milnes, Christine Horrocks, Nancy Kelly, Brian Roberts, and David Robinson, 63-79. Huddersfield, UK: University of Huddersfield Press, 2006.

Bamberg, Michael. "Stories: Big or Small: Why Do We Care?” Narrative Inquiry 16, no. 1 (2006): 139-147.

Bartesaghi, Mariaelena, and Sheryl Perlmutter Bowen. "The Acquisition of Memory by Interview Questioning: Holocaust Re-membering as Category-Bound Activity." Discourse Studies 11, no. 2 (2009): 222-243.

Becker, Heike. Namibian Women's Movement, 1980 to 1992: From Anti-Colonial Resistance to Reconstruction. Frankfurt am Main: IKO-Verlag für Interkulturelle Kommunikation, 1995.

Bender, Barbara. "Introduction." In Contested Landscapes: Movement, Exile and Place, edited by Barbara Bender and Margot Winer, 1-18. Oxford: Berg, 2001.

Bender, Barbara, Sue Hamilton, and Chris Tilley, eds. Stone Worlds: Narrative and Reflexivity in Landscape Archaeology. Walnut Creek, CA: Left Coast Press, 2007.

Bender, Barbara. "Time and Landscape." Current Anthropology 43, S4 (2002): S103-S112.

Berleant, Arnold. Aesthetics and Environment. Burlington, VT: Ashgate, 2005.

Berleant, Arnold. "Aesthetic Engagement and the Human Landscape." Paper presented at the International Conference on Environment, Aesthetic Engagement, and the Public Sphere, Paris, May 9, 2007. Accessed January 17, 2018. https://hcommons.org/deposits/ item/hc:16781/.

Berleant, Arnold. Living in the Landscape: Toward an Aesthetics of Environment. Kansas: University Press of Kansas, 1997.

Berleant, Arnold. Sensibility and Sense: The Aesthetic Transformation of the Human World. Exeter: Imprint Academic, 2010.

"Bernardo Moisés Goy-Goy." In Protagonistas da luta de libertação nacional, compiled and edited by Ana Bouene Mussanhane, 217-224. Maputo: Marimbique, 2012.

Bertelsen, Bjørn Enge. Violent Becomings: State Formation, Sociality, and Power in Mozambique. New York: Berghahn Books, 2016.

Bhabha, Homi. "DissemiNation: Time, Narrative, and the Margins of the Modern Nation." In Nation and Narration, edited by Homi Bhabha, 291-322. London: Routledge, 1990.

Bloch, Ernst. “Can Hope Be Disappointed?” In Literary Essays, translated by Andrew Joron and others, 339-345. Stanford: Stanford University Press, 1998.

Blunt, Alison, and Robyn Dowling. Home. London: Routledge, 2006.

Boehmer, Elleke. Stories of Women: Gender and Narrative in the Post-Colonial Nation. Manchester: Manchester University Press, 2005.

Boehmer, Elleke. "Transfiguring: Colonial Body into Postcolonial Narrative." NOVEL: A Forum on Fiction 26, no. 3 (1993): 268-277. 


\section{Bibliography}

Böhme, Gernot. "Acoustic Atmospheres: A Contribution to the Study of Ecological Aesthetics." Soundscape: The Journal of Acoustic Ecology 1, no. 1 (2000): 14-18.

Böhme, Gernot. "Atmosphere as the Fundamental Concept of a New Aesthetics." Thesis Eleven 36 (1993): 113-126.

Böhme, Gernot. "Urban Atmospheres: Charting New Directions for Architecture and Urban Planning." In Architectural Atmospheres: On the Experience and Politics of Architecture, edited by Christian Borch, 43-59. Basel: Birkhäuser, 2014.

Bollig, Michael. "Visions of Landscape: An Introduction." In African Landscapes. Interdisciplinary Approaches, edited by Michael Bollig and Olaf Bubenzer, 1-38. New York: Springer, 2009.

Bonate, Liazzat. "Islam in Northern Mozambique: A Historical Overview." History Compass 8/7 (2010): 573-593.

Bonate, Liazzat. "Matriliny, Islam and Gender in Northern Mozambique.” Journal of Religion in Africa 2, no. 36 (2006): 139-166.

Bonate, Liazzat. "Muslim Memories of the Liberation War in Cabo Delgado." Kronos 39, no. 1 (2013): 230-256.

Bonate, Liazzat."Roots of Diversity in Mozambican Islam." Lusotopie 14, no. 1 (2007): 127-149.

Bonate, Liazzat. "Yao, Islam and the." Oxford Islamic Studies Online. Accessed July 13, 2012. www.oxfordislamicstudies.com/article/opr/t343/e0055.

Bowen, Merle L. The State Against the Peasantry. London: University Press of Virginia, 2000.

Brady, Emily. "The Sublime, Ugliness and Terrible Beauty in Icelandic Landscapes.” In Conversations with Landscape, edited by Karl Benediktsson and Katrín Anna Lund, 125-136. Aldershot: Ashgate, 2010.

Braga, Carla. “'They are Squeezing Us!' Matrilineal Kinship, Power and Agricultural Policies: Case Staudy of Issa Malanga, Niassa Province.” In Strategic Women, Gainful Men: Gender, Land and Natural Resources in Different Rural Contexts in Mozambique, edited by Rachel Waterhouse and Carin Vijfhuizen, 199-225. Maputo: UEM; ActionAid-Mozambique, Maputo, 2001.

Bragança, Aquino de and Jacques Depelchin. "From the Idealization of Frelimo to the Understanding of the Recent History of Mozambique." African Journal of Political Economy 1, no. 1 (1986): 162-180.

Brinkman, Inge. "Landscape and Nostalgia: Angolan Refugees in Namibia Remembering Home and Forced Removals." In African Landscapes. Interdisciplinary Approaches, edited by Michael Bollig and Olaf Bubenzer, 275-294. New York: Springer, 2009.

Brinkman, Inge. "Routes and the War for Independence in Northern Angola (1961-74)." Canadian Journal of African Studies 40, no. 2 (2006): 205-234.

Brinkman, Inge. "Town, Village and Bush: War and Cultural Landscapes in South-Eastern Angola (1966-2002).” Afrika Focus 25, no. 2 (2012): 31-43.

Bruner, Jerome. "A Narrative Model of Self-Construction." Annals of the New York Academy of Sciences (December 2006): 145-161.

Bruner, Jerome. "Life as Narrative." Social Research 71, no. 3 (2004): 691-710.

Bruner, Jerome. "Narratives of Aging." Journal of Aging Studies 13, no. 1 (1999): 7-9.

Butler, Judith. Bodies that Matter: On the Discursive Limits of "Sex." London: Routledge, 1993. Butler, Judith. Frames of War: When is Life Grievable? London: Verso, 2009.

Butler, Judith. "Gendering the Body: Beauvoir's Philosophical Contribution.” In Women, Knowledge, and Reality, edited by Ann Garry and Marilyn Pearsall, 253-262. London: Unwin Hyman, 1989.

Butler,Judith. Gender Trouble. 2nd edition. London: Routledge, 2006. First published in 1990. 
Butler, Judith. "Performing Acts and Gender Constitution: An Essay in Phenomenology and Feminist Theory." Theatre Journal 40, no. 4 (1988): 519-531.

Butler, Judith. "Sexual Ideology and Phenomenological Description: A Feminist Critique of Merleau-Ponty's Phenomenology of Perception." In The Thinking Muse: Feminism and Modern French Philosophy, edited by Jeffner Allen and Iris Marion Young, 85-100. Indianapolis: Indiana University Press, 1989.

Buttimer, Anne. "Home, Reach, and the Sense of Place." In The Human Experience of Space and Place, edited by Anne Buttimer and David Seamon, 166-187. London: Croom Helm, 1980.

Cabaço, José Luís. Moçambique: identidades, colonialismo e libertação. Maputo: Marimbique, 2010.

Cabrita, João M. Mozambique: The Tortuous Road to Democracy. Basingstoke: Palgrave Macmillan, 2000.

Cahen, Michel. "Anticolonialism \& Nationalism: Deconstructing Synonymy, Investigating Historical Process." In Sure Road? Nationalisms in Angola, Guinea-Bissau and Mozambique, edited by Eric Morier-Genoud, 1-30. Leiden: Brill, 2012.

Cahen, Michel. "Check on Socialism in Mozambique-What Check? What Socialism?" Review of African Political Economy 57 (1993): 46-59.

Cahen, Michel. "The Mueda Case and Maconde Political Ethnicity. Some Notes on a Work in Progress." Africana Studia 2 (1999): 29-46.

Cahen, Michel. "Nationalism and Ethnicities: Lessons from Mozambique." In Ethnicity Kills?: The Politics of War, Peace, and Ethnicity in SubSaharan Africa, edited by Einar Braathen, Morten Bøas, and Gjermund Sæther, 163-187. Basingstoke: Macmillan, 2000.

Campbell, Horace. Reclaiming Zimbabwe: The Exhaustion of the Patriarchal Model of Liberation. Trenton, NJ: Africa World Press, 2003.

Carr, David. Experience and History: Phenomenological Perspectives on the Historical World. Oxford: Oxford University Press, 2014.

Casey, Edward S. "Body, Self, and Landscape: A Geophilosophical Inquiry into the PlaceWorld." In Textures of Place: Exploring Humanist Geographies, edited by Paul C. Adams, Steven Hoelscher, and Karen E. Till, 403-419. University of Minnesota Press, 2001.

Casey, Edward S. "Habitual Body and Memory in Merleau-Ponty." Man and World 17 (1984): 279-297.

Casey, Edward S. "How to Get from Space to Place in a Fairly Short Stretch of Time: Phenomenological Prolegomena.” In Senses of Place, edited by Steven Feld and Keith H. Basso, 13-52. Santa Fe: School of American Research Press, 1997.

Casimiro, Isabel Maria. "Paz na terra, guerra em casa": feminismo e organizações de mulheres em Moçambique. Maputo, Promédia, 2004.

Casimiro, Isabel Maria. "Repensando as relações entre mulher e homem no tempo de Samora." In Samora: homem do povo, edited by António Sopa, 127-135. Maputo: Maguezo, 2001.

Casimiro, Isabel Maria. "Samora Machel e as relações de género." Estudos Moçambicanos 21 (Maputo: UEM, 2005): 55-84.

Casimiro, Isabel Maria. "Transformação nas relações homem/mulher em Moçambique 1960-1974.” Tese de Licenciatura em História, UEM, 1986.

Castree, Noel. “The Spatio-temporality of Capitalism.” Time \& Society 18, no. 1 (2009): 26-61.

"Centro de Reeducação de Msauíze: transformar pelo trabalho marginais da sociedade colonial." Notícias (Maputo), 13 August 1976, 4. Accessed March 26, 2016. www.mozam biquehistory.net/reeducation.php.

Chichava, Sérgio. “'They Can Kill Us but We Won't Go to the Communal Villages!' Peasants and the Policy of 'Socialisation of the Countryside' in Zambezia.' Kronos 39, no. 1 (2013): 112-130. 
Chisholm, Dianne. "Climbing like a Girl: An Exemplary Adventure in Feminist Phenomenology." Hypatia 23, no. 1 (2008): 9-40.

Cock, Jacklyn. "Women and the Military: Implications for Demilitarization in the 1990s in South Africa." Gender and Society 8, no. 2 (1994): 152-169.

Cockburn, Cynthia. The Space Between Us: Negotiating Gender and National Identities in Conflict. London: Zed Books, 1998.

Coelho, João Paulo Borges. "Abrir a fábula: questões da política do passado em Moçambique." Revista Critica de Ciências Sociais 106 (2015): 153-166.

Coelho, João Paulo Borges. "Politics and Contemporary History in Mozambique: A Set of Epistemological Notes.” Kronos 39, no. 1 (2013): 20-31.

Cohen, David William, and E. S. Atieno Odhiambo. Siaya: The Historical Anthropology of an African Landscape. London: James Currey, 1989.

Connell, R. W. Masculinities. Cambridge: Polity Press, 1995.

"Correcção de deficiências na Operação Produção: Ministro Guebuza esteve no Niassa." Notícias (Maputo), April 10, 1984. Accessed March 26, 2016. www.mozambiquehistory. net/history/operacao_producao/19840410_deficiencies_of_operation.pdf.

Cosgrove, Denis. "Prospect, Perspective and the Evolution of the Landscape Idea." Transactions for the Institute of British Geographers 10 (1985): 45-62.

Coupland, Nikolas. Style: Language Variation and Identity. Cambridge: Cambridge University Press, 2007.

Crang, Mike. "Urban Morphology and the Shaping of the Transmissable City." City 4, no. 3 (2000): 303-315.

Cravinho, J. T. G. "Modernizing Mozambique: Frelimo Ideology and the Frelimo State." PhD diss., University of Oxford, 1995.

Cresswell, Tim. Place: A Short Introduction. Malden, MA: Blackwell Pub, 2004.

Cresswell, Tim, and Tunu Priya Uteng. "Gendered Mobilities: Towards a Holistic Understanding." In Gendered Mobilities, edited by Tanu Priya Uteng, and Tim Cresswell, 1-12. Burlington, VT: Ashgate, 2008.

"Daniel Assahel Polela." In Protagonistas da luta de libertação nacional, compiled and edited by Ana Bouene Mussanhane, 281-288. Maputo: Marimbique, 2012.

Daniels, Stephen, and Denis Cosgrove. The Iconography of Landscape. Cambridge: Cambridge University Press, 1988.

Dauphinée, Elizabeth. "The Politics of the Body in Pain: Reading the Ethics of Imagery." Security Dialogue 38 (2007): 139-155.

Davidson, Julia O’Connell. "If No Means No, Does Yes Mean Yes? Consenting to Research Intimacies." History of the Human Sciences 21, no. 4 (2008): 49-67.

Davies, Bronwyn. (In)scribing Body/landscape Relations. Walnut Creek, CA: AltaMira, 2000.

Davies, Kathy. "Intersectionality as Buzzword: A Sociology of Science Perspective on What Makes a Feminist Theory Successful." Feminist Theory 9, no. 1 (2008): 67-85.

Derluguian, Georgi. "The Social Origins of Good and Bad Governance: Re-interpreting the 1968 Schism in Frelimo." In Sure Road? Nationalisms in Angola, Guinea-Bissau and Mozambique, edited by Eric Morier-Genoud, 79-101. Leiden: Brill, 2012.

Desjarlais, Robert. Sensory Biographies: Lives and Deaths among Nepal's Yolmo Buddhists. Berkeley, CA: University of California Press, 2003.

Deutsch, Jan-Georg, Heike Schmidt, and Peter Probst. African Modernities: Entangled Meanings in Current Debate. Oxford: James Currey, 2001.

Dicks, Ian D. An African Worldview: The Muslim Amacinga Yawo of Southern Malawii. Zomba: Kachere Series, 2012. 
Dieckmann, Ute. "The Spectator's and the Dweller's Perspectives: Experience and Representation of the Etosha National Park, Namibia." In African Landscapes. Interdisciplinary Approaches, edited by Michael Bollig and Olaf Bubenzer, 353-381. New York: Springer, 2009.

Dinerman, Alice. Revolution, Counter-Revolution and Revisionism in Postcolonial Africa: The Case of Mozambique, 1975-1994. London: Routledge, 2006.

Dingemanse, Mark. "Advances in the Cross-Linguistic Study of Ideophones." Language and Linguistics Compass 6 (2012): 654-672.

Disney, Jennifer Leigh. Women's Activism and Feminist Agency in Mozambique and Nicaragua. Philadelphia: Temple University Press, 2008.

Dos Santos, Nuno Beja Valdez Thomaz. O desconhecido Niassa. Lisboa: Junta de Investigação do Ultramar, 1964.

Downey, Greg."Educating the Eyes: Biocultural Anthropology and Physical Education." Anthropology in Action: Journal for Applied Anthropology in Policy and Practice 12, no. 2 (2005): 56-71.

Economist Intelligence Unit (EIU). “Country Report: Mozambique” (EIU,6 October 2015).

Edensor, Tim. "Introduction: Thinking about Rhythm and Space." In Geographies of Rhythm: Nature, Place, Mobilities and Bodies, edited by Tim Edensor, 1-18. Burlington, VT: Ashgate, 2010.

Englund, Harri. "Death, Trauma and Ritual: Mozambican Refugees in Malawi." Social Science \& Medicine 46, no. 9 (1998): 1165-1174.

Enloe, Cynthia. Bananas, Beaches and Bases: Making Feminist Sense of International Politics. Berkley: University of California Press, 1989.

Enloe, Cynthia. Does Khaki Become You? The Militarization of Women's Lives. London: Pandora Press, 1988.

Enloe, Cynthia. Maneuvers: The International Politics of Militarizing Women's Lives. Berkeley: University of California Press, 2000.

"Familiares de ex-reeducandos brevemente no Niassa." Notícias (Maputo), 17 December 17, 1981. Accessed March 26, 2016. www.mozambiquehistory.net/justice/reeducation/1980 0814_familias_no_niassa.pdf.

Fanon, Frantz. Black Skin, White Masks. Translated from French by Charles Lam Markmann. London: Pluto Press, 2008. Originally published as Peau noire, masques blancs (Paris: Les Éditions du Seuil, 1952).

Farnell, B."Moving Bodies, Acting Selves." Annual Review of Anthropology 28 (1999): 341-373.

Feld, Steven, and Keith H. Basso, eds. Senses of Place. Santa Fe: School of American Research Press, 1996.

Ferguson, James. Expectations of Modernity: Myths and Meanings of Urban Life on the Zambian Copperbelt. Berkeley: University of California Press, 1999.

Fernardes, Carlos. "History Writing and State Legitimisation in Postcolonial Mozambique: The Case of the History Workshop, Centre for African Studies, 1980-1986." Kronos 39, no. 1 (2013): 131-157.

“First Conference of Mozambican Women.” Mozambique Revolution 54 (1973): 22-24.

First, Ruth. Black Gold: The Mozambican Miner, Proletarian and Peasant. Sussex: The Harvester Press, 1983.

Foucault, Michel. Discipline and Punish: The Birth of the Prison. Translated from French by Alan Sheridan. New York: Vintage Books, 1995. Originally published as Surveiller et punir: Naissance de la prison (Paris: Éditions Gallimard, 1975).

"Frelimo cria campos de reeducação." A Capital (Lisboa), November 20, 1974. Accessed March 26, 2016. www.mozambiquehistory.net/justice/reeducation/19741120_frelimo_ cria_campos.pdf. 


\section{Bibliography}

Frelimo. História da FRELIMO. Maputo: Imprensa do Partido, 1981.

Funada-Classen, Sayaka. The Origins of War in Mozambique: A History of Unity and Division. Oxford: African Minds, 2013.

Galli, Rosemary Elizabeth. Peoples' Spaces and State Spaces: Land and Governance in Mozambique. Oxford: Lexington Books, 2003.

Geiger, Susan. TANU Women: Gender and Culture in the Making of Tanganyikan Nationalism 1955-1965. Portsmouth, NH: Heinemann, 1997.

Gengenbach, Heidi. "Naming the Past in a 'Scattered' Land: Memory and the Powers of Women's Naming Practices in Southern Mozambique." The International Journal of African Historical Studies 33, no. 3 (2000): 523-542.

Gengenbach, Heidi. "Truth-Telling and the Politics of Women's Life History Research in Africa: A Reply to Kirk Hoppe." The International Journal of African Historical Studies 27, no. 3 (1994): 619-627.

Gibson, James J. The Senses Considered as Perceptual Systems. London: Allen \& Unwin, 1968.

Granjo, Paulo. "Limpeza ritual e reintegração pós-guerra em Moçambique." Análise Social XLII (2007): 123-144.

Grosz, Elizabeth. "Merleau-Ponty and Irigaray in the Flesh." Thesis Eleven 36 (1993): 37-59.

Grosz, Elizabeth. Volatile Bodies. Indiana: Indiana Press, 1994.

"Guebuza deixa promessas de melhorar a rede rodoviária." O País (Maputo), March 24, 2014. Accessed March 26, 2016. http://opais.sapo.mz/index.php/component/content/ article/63-politica/29191-guebuza-deixa-promessas-de-melhorar-a-rede-rodoviaria-. html.

Guenther, Katja M. "The Politics of Names: Rethinking the Methodological and Ethical Significance of Naming People, Organizations, and Places." Qualitative Research 9, no. 4 (2009): 411-421.

Guerts, Kathryn Linn. Culture and the Senses: Bodily Ways of Knowing in an African Community. Berkeley, CA: University of California Press, 2002.

Gune, Emídio, and Sandra Manuel. "Doing Research on Sexuality in Africa: Ethical Dilemmas and the Positioning of the Researcher." OSSEREA Bulletin 4, no. 2 (2007): 23-32.

Hahn, Hans Peter, and Kristin Kastner. Urban Life-Worlds in Motion: African Perspectives. Bielefeld: Transcript Verlag, 2012.

Halberstam, Jack. Female Masculinity. London: Duke University Press, 1998.

Halbwachs, Maurice. The Collective Memory. Translated from French by Francis J. Ditter, Jr. and Vida Y. Ditter. New York: Harper \& Row, 1980. Originally published as La mémoire collective (Paris: Les Presses universitaires de France, 1950).

Hall, Margaret, and Tom Young. Confronting Leviathan: mozambique since Independence. London: Hurst \& Company, 1997.

Hanlon, Joseph. Mozambique: The Revolution under Fire. London: Zed Books, 1984.

Hanlon, Joseph, and Teresa Smart. Há mais bicicletas—mas há desenvolvimento? Maputo: Promedia, 2008.

Haraway, Donna. "Situated Knowledge: The Science Question in Feminism and the Privilege of Partial Perspective." Feminist Studies 14, no. 3 (1988): 575-599.

Harvey, David. Social Justice and the City. Baltimore, MD: The Johns Hopkins University Press, 1973.

Harvey, David. "The Sociological and Geographical Imaginations." International Journal of Politics, Culture E Society 18, no. 3/4 (2005): 211-255.

Hayes, Patricia. "A Land of Goshen: Landscape and the Kingdom in Nineteenth Century Eastern Owambo (Namibia)." In African Landscapes. Interdisciplinary Approaches, edited by Michael Bollig and Olaf Bubenzer, 225-254. New York: Springer, 2009. 
Heinämaa, Sara. “A Phenomenology of Sexual Difference: Types, Styles and Persons.” In Feminist Metaphysics: Explorations in the Ontology of Sex, Gender and Identity, edited by Charlotte Witt, 131-155, Dordrecht: Springer, 2011.

Heinämaa, Sara. Ele, tyyli ja sukupuoli: Merleau-Pontyn ja Beauvoirin ruumiinfenomenologia ja sen merkitys sukupuolikysymykselle [Gesture, Style and Sex: Beauvoir's and Merleau-Ponty's Phenomenology of the Body and its Relevance to the Problem of Sexual Difference]. Tampere: Tampere-paino, 1996.

Heinämaa, Sara. "Personality, Anonymity, and Sexual Difference: The Temporal Formation of the Transcendental Ego." In Time in Feminist Phenomenology, edited by Christina Schües, Dorothea E. Olkowski, and Helena A. Fielding, 41-59. Bloomington: Indiana University Press, 2011.

Heinämaa, Sara. "Sex, Gender and Embodiment." In The Oxford Handbook of Contemporary Phenomenology, edited by Dan Zahavi, 216-242. Oxford: Oxford University Press, 2012.

Heinämaa, Sara. Toward a Phenomenology of Sexual Difference: Husserl, Merleau-Ponty, Beauvoir. Oxford: Rowman \& Littlefield Publishers, 2003.

Heinämaa, Sara. "Woman-Nature, Product, Style?: Rethinking the Foundations of Feminist Philosophy of Science." In Feminism, Science, and the Philosophy of Science, edited by Lyn Hankinson Nelson and Jack Nelson, 289-308. London: Kluwer Academic Publishers, 1996. Henriksen, Thomas H. “Marxism and Mozambique.” African Affairs 77, no. 309 (1978): 441-462. Henriksen, Thomas H. Mozambique: A History. London: Rex Collings, 1978.

Henry, Doug. "Violence and the Body: Somatic Expressions of Trauma and Vulnerability during War." Medical Anthropology Quarterly 20, no. 3 (2006): 379-398.

Hester, Stephen, and Peter Englin. "Membership Categorization Analysis: An Introduction." In Culture in Action: Studies in Membership Categorization Analysis, edited by Stephen Hester and Peter Eglin, 1-23. Washington, D.C.: University Press of America, 1997.

Honwana, Alicinda. Child Soldiers in Africa. Philadelphia: University of Philadelphia, 2006.

Howard, Allen M. "Actor, Places, Regions, and Global Forces: An Essay on the Spatial History of Africa Since 1700.” In Respacing Africa, edited by Paul Nugent and Ulf Engel, 11-44. Leiden: Brill, 2010.

Howard, Allen M., and Richard M. Shain, eds. The Spatial Factor in African History: The Relationship of the Social, Material, and Perceptual. Leiden: Brill, 2005.

Huhn, Arianna. "Sustenance and Sociability: Foodways in a Mozambican Town." PhD diss., Boston University, 2013.

Hurst, Ellen, and Rajend Mesthrie. "When You Hang Out with the Guys They Keep You in Style": The Case for Considering Style in Description of African Tsotsitaals." Language Matters: Studies in Languages of Africa 44, no. 1 (2013): 3-20.

Hyvärinen, Matti “'Life as Narrative' Revisited.” Partial Answers: Journal of Literature and The History of Ideas 6, no. 2 (2008): 691-277.

Igreja, Victor. "Frelimo's Political Ruling through Violence and Memory in Postcolonial Mozambique." Journal of Southern African Studies 36, no. 4 (2010): 781-799.

Igreja, Victor. "Gamba Spirits, Gender Relations, and Healing in Post-Civil War Gorongosa, Mozambique." Journal of the Royal Anthropological Institute 14 (2008): 353-371.

Igreja, Victor. "Legacies of War, Healing, Justice, and Social Transformation in Mozambique." In Psychosocial Perspectives on Peacebuilding, edited by Brandon Hamber and Elizabeth Gallagher, 223-254, London: Springer 2015.

Igreja, Victor. "The Politics of Peace, Justice and Healing in Post-War Mozambique: 'Practices of Rupture' by Magamba Aspirits and Healers in Gorongosa.” In Peace versus Justice? The Dilemma of Transitional Justice in Africa, edited by Chandra Lekha and Suren Pillay, 277-300. Scottsville: University of KwaZulu-Natal Press, 2009. 


\section{Bibliography}

Ingold, Tim. "Footprints through the Weather-World: Walking, Breathing, Knowing." Journal of the Royal Anthropological Institute 16, no. S1 (2010): 121-139.

Ingold, Tim. The Perception of the Environment: Essays in Livelihood, Dwelling and Skill. London: Routledge, 2000.

Ingold, Tim. “The Temporality of the Landscape.” World Archaeology 25, no. 2 (1993): 152-174.

Ingold, Tim. "Three in One: On Dissolving the Distinctions Between Body, Mind and Culture." In Imagining Culture: Practices of Cosmology and Identity, edited by Nils Bubandt, Kalevi Kull, and Andreas Roepstorff, 40-55. Aarhus: Aarhus University Press, 2003.

Instituto Nacional de Estatística (hereafter INE). "Censo agro-pecuário CAP 2009-2010: Resultados definitivos-Moçambique” (Maputo: INE, 2011). Accessed March 26, 2016. www.ine.gov.mz/operacoes-estatisticas/censos/censo-agro-pecuario/cap-2009-2010.

INE. "Estatísticas do distrito de cidade de Lichinga 2013" (Maputo: INE, 2013). Accessed March 26, 2016. www.ine.gov.mz/estatisticas/estatisticas-territorias-distritais/niassa.

INE. "Recenseamento geral da população e habitação 2007: Indicadores socio-demográficos: província de Niassa” (Maputo: INE, 2007). Accessed March 26, 2016. www.ine.gov.mz/ operacoes-estatisticas/censos/censo-2007/rgph-2007/indicadores-socio-demograficosprovincia-de-niassa-2007.pdf/view.

Isaacman, Allen, and Barbara Isaacman. Mozambique: From Colonialism to Revolution, 19001982. Boulder, CO: Westview, 1983.

Isaacman, Allen, and Barbara Isaacman. "The Role of Women in the Liberation of Mozambique." Ufahamu: Journal of the African Activist Association 13, no. 2 (1984): 128-185.

Isaacman, Barbara and June Stephen. A mulher moşambicana no processo de libertação. Maputo: Instituto Nacional do Livro e do Disco, 1982.

Israel, Paulo. "The Formulaic Revolution: Song and the "Popular Memory" of the Mozambican Liberation Struggle." Cahiers d'Etudes Africaines 1, no. 197 (2010): 181-216.

Israel, Paulo. "Lingundumbwe: Feminist Masquerades and Women's Liberation, Nangade, Mueda, Muidumbe, 1950s-2005.” Kronos 39 (2013): 204-229.

James, Wendy, and David Mills. "Introduction: From Representation to Action in the Flow of Time.” In The Qualities of Time: Anthropological Approaches, edited by Wendy James and David Mills, 1-15. Oxford: Berg, 2005.

Jayawardena, Kumari. Feminism and Nationalism in the Third World.London: Zed Books, 1986. Jayyusi, Lena. Categorization and the Moral Order. London: Routledge and Keagan Paul, 1984. Jenkins, Paul. "Image of the City in Mozambique: Civilization, Parasite, Engine of Growth or Place of Opportunity." In African Urban Economies: Viability, Vitality, or Vitiation?, edited by Deborah Fahy Bryceson and Deborah Potts, 107-130. New York: Palvgrave, 2006.

Jóhannesdóttir, Guðbjörg Rannveig. "Icelandic Landscapes: Beauty and the Aesthetic in Environmental Decision-Making.” PhD diss., University of Iceland, 2015.

Jóhannesdóttir, Guðbjörg Rannveig. "Landscape and Aesthetic Values: Not Only in the Eye of the Beholder." In Conversations with Landscape, edited by Karl Benediktsson and Katrín Anna Lund, 109-124. Burlington, VT: Ashgate Pub., 2010.

Johnson, Galen A. The Retrieval of the Beautiful: Thinking Through Merleau-Ponty's Aesthetics. Evanston, IL: Northwestern University Press, 2010.

Jonas, André."Mavago em crescimento." Notícias (Maputo), October 1, 2013. Accessed March 26, 2016. www.jornalnoticias.co.mz/index.php/sociedade/3774-mavago-em-crescimento.

“José Phahlane Moyane." In Protagonistas da luta de libertação nacional, compiled and edited by Ana Bouene Mussanhane, 451-473. Maputo: Marimbique, 2012.

Käll, Lisa Folkmarson. "A Being of Two Leaves-On the Founding Significance of the Lived Body." In Body Claims, edited by Janne Bromseth, Lisa Folkmarson Käll, and Katarina Mattsson, 110-133. Uppsala: University Printers, 2009. 
Käll, Lisa Folkmarson. "Vulnerable Bodies and Embodied Boundaries." In Bodies, Boundaries and Vulnerabilities: Interrogating Social, Cultural and Political Aspects of Embodiment, edited by Lisa Folkmarson Käll, 1-12. London: Springer, 2016.

Katto, Jonna. 'A avó foi guerrilheira': memórias de vida das mulheres que lutaram pela independência de Moçambique no norte do Niassa/ 'Grandma was a Guerrilla Fighter': Women who Fought for Mozambique's Independence in Northern Niassa. Portuguese translation by João Figueiredo. Tallinna, 2018.

Katto, Jonna. "Emotions in Protest: Unsettling the Past in Ex-Combatants' Personal Accounts in Northern Mozambique." Oral History 46, no. 2 (2018): 53-62.

Katto, Jonna. "Landscapes of Belonging: Female Ex-Combatants Remembering the Liberation Struggle in Urban Maputo." Journal of Southern African Studies 40, no. 3 (2014): $539-557$.

Kavari, Jekura U., and Laura Bleckmann. "Otjiherero Praises of Places: Collective Memory Embedded in Landscape and the Aesthetic Sense of a Pastoral People." In African Landscapes. Interdisciplinary Approaches, edited by Michael Bollig and Olaf Bubenzer, 473-501. New York: Springer, 2009.

Klassen, Doreen Helen. "You Can't Have Silence with Your Palms Up: Ideophones, Gesture, and Iconicity in Zimbabwean Shona Women's Ngano (Storysong) Performance." PhD diss., Indiana University, 1999.

Kriger, Norma. Zimbabwe's Guerrilla War: Peasant Voices. Cambridge: Cambridge University Press, 1991.

Kruks, Sonia, and Ben Wisner. "The State, the Party and the Female Peasantry in Mozambique." Journal of Southern African Studies 11, no. 1 (1984): 106-127.

Labov, William. The Language of Life and Death: The Transformation of Experience in Oral Narrative. Cambridge: Cambridge University Press, 2013.

Lapchick, Richard E., and Stephanie Urdang. Oppression and Resistance: The Struggle of Women in Southern Africa. London: Greenwood Press, 1982.

Lee, Jo, and Tim Ingold. "Fieldwork on Foot: Perceiving, Routing, Socializing.” In Locating the Field: Space, Place and Context in Anthropology, edited by Simon Coleman and Peter Collins, 67-85. New York: Berg, 2006.

Lefebvre, Henri. The Production of Space. Translated from French by Donald NicholsonSmith. Oxford: Blackwell, 1991. Originally published as La production de l'espace (Paris: Éditions Anthropos, 1974).

Lefebvre, Henri. Rhythmanalysis: Space, Time and Everyday Life. Translated from French by Stuart Eldon and Gerald Moore. New York: Continuum, 2004. Originally published as Éléments de rythmanalyse (Paris: Éditions Syllepse, 1992).

Lefebvre, Henri, and Catherine Régulier. "Attempt at the Rhythmanalysis of Mediterranean Cities.” In Rhythmanalysis: Space, Time and Everyday Life, edited by Henri Lefebvre, 87-100. New York: Continuum, [1992] 2004.

Liesegang, Gerhard. "A estrutura política, a estratificação social e o lugar dos chefes na estrutura económica e religiosa antes da conquista colonial." In História do Niassa. Vol. 1. Maputo, unpublished manuscript, 2014[1990?].

Liesegang, Gerhard. "Guerras, terras e tipos de povoações: sobre uma 'tradição urbanistica' do norte de Moçambique no século XIX.” Revista Internacional de Estudos Áfricanos 1 (1984): 169-184.

Liesegang, Gerhard. História do Niassa ca. 1600-1918: estados, política e economia no periodo precolonial e a conquista colonial. Maputo, unpublished manuscript, n.d.

Lubkemann, Stephen. Culture in Chaos: An Anthropogy of the Social Condition in War. London: University of Chicago Press, 2008. 


\section{Bibliography}

Luig, Ute, and Achim von Oppen. "Landscape in Africa: Process and Vision." In The Making of African Landscapes, edited by Ute Luig and Achim von Oppen, 7-45. Vol. 43 of Paideuma, Mitteilungen zur Kulturkunde. Stuttgart: Steiner, 1997.

Lyons, Tanya. Guns and Guerilla Girls: Women in the Zimbabwean Liberation Struggle. Trenton, NJ: Africa World Press, 2004.

Lyons, Terence. Demilitarizing Politics: Elections on the Uncertain Road to Peace. Boulder, CO: Lynne Reinner, 2005.

Macamo, Elísio. "Negotiating Modernity: From Colonialism to Globalization." In Negotiating Modernity: Africa's Ambivalent Experience, edited by Elísio Salvado Macamo, 1-16. Dakar: Codesria, 2005.

MacDonald, Duff. Africana or the Heart of Heathen Africa. Vol. 1. London: Simpkin Marchall and Co., 1882.

Machava, Benedito Luís. "The Morality of Revolution: Urban Cleanup Campaigns, Reeducation Camps.” PhD diss., University of Michigan, 2018.

Machel, Josina. "The Role of Women in the Struggle." Mozambique Revolution 41 (1969): 24-27.

Machel, Samora. "Defining Women's Enemy." In Samora Machel: An African Revolutionary: Selected Speeches and Writings, edited by Barry Munslow, London: Zed Books, 1985, 169-178.

Machel, Samora. "Educate Man to Win the War, Create a New Society and Develop our Country." In Mozambique: Sowing the Seeds of Revolution, edited by Samora Machel, 33-41. Harare: Zimbabwe Publishing House, 1981.

Machel, Samora. "The Liberation of Women is a Fundamental Necessity for the Revolution." In Mozambique: Sowing the Seeds of Revolution, edited by Samora Machel (Harare: Zimbabwe Publishing House, 1981), 17-31.

"Machel's Speech on Unjust Detentions in Re-Education Camps." BBC Summary of World Broadcasts (London), no. ME/6846, October 6, 1981, B/1-. Accessed March 26, 2016. www.mozambiquehistory.net/justice/reeducation/19811001_unjust_detentions_in_ centres.pdf.

Maloba, W. O. African Women in Revolution. Trenton, NJ: Africa World Press, 2007.

Malpas, Jeff. "Place and the Problem of Landscape." In The Place of Landscape: Concepts, Contexts, Studies, edited by Jeff Malpas, 3-26. Cambridge, MA: MIT Press, 2011.

Malpas, Jeff."Putting Space in Place: Philosophical Topography and Relational Geography." Environment and Planning D: Society and Space 30 (2012): 226-242.

Manguedye, Marina and Raimundo Pachinuapa. A vida do casal Pachinuapa. Maputo: JV Editores, 2009.

Manning, Erin. Politics of Touch: Sense, Movement, Sovereignty. Minneapolis: University of Minnesota Press, 2007.

Marks, Laura U. The Skin of the Film: Intercultural Cinema, Embodiment, and the Senses. Durham, NC: Duke University Press, 2000.

Massey, Doreen. For Space. London: SAGE, 2005.

Massey, Doreen. "Landscape as a Provocation: Reflections on Moving Mountains." Journal of Material Culture 11, nos. 1-2 (2006): 33-48.

Massey, Doreen. “Landscape/Space/Politics: An Essay." 2010. Accessed May 4, 2016. http:// thefutureoflandscape.wordpress.com/landscapespacepolitics-an-essay.

Massey, Doreen. "Politics and Space/Time." New Left Review I, no. 196 (1992): 65-84.

Massey, Doreen. Space, Place, and Gender. Minneapolis: University of Minnesota Press, 1994.

Mateus, Dalila Cabrita. A luta pela independência: a formação das elites fundadores da FRELIMO, MPLA e PAIGC. Mem Martins: Inquérito, 2006. 
Mateus, Dalila Cabrita, and Álvaro Mateus. Nacionalistas de Moçambique. Alfragide: Texto Editores, 2010.

Mavanga, B. "Nos ex-centros de reeducação, trezentos lares reconstruídos no Niassa." Notícias (Maputo), June 11, 1982. Accessed March 26, 2016. www.mozambiquehistory.net/ justice/reeducation/19820611_ex-centros_de_reeducacao.pdf.

Mayer, Tamara. "Nationalism: Setting the Stage." In Gender Ironies of Nationalism: Sexing the Nation, edited by Tamara Mayer, 1-24. London: Routledge, 2000.

Mazrui, Ali. "Gandhi, Marx and the Warrior Tradition: Towards Androgynous Liberation." Journal of Asian and African Studies XII, nos. 1-4 (1977): 179-196.

Mazurana, Dyan E., Susan A. McKay, Khristopher C. Carlson, and Janel C. Kasper. "Girls in Fighting Forces and Groups: Their Recruitment, Participation, Demobilization, and Reintegration." Peace and Conflict: Journal of Peace Psychology 8, no. 2 (2002): 97-123.

Mbembe, Achille. "Variations on the Beautiful in the Congolese World of Sounds." In Beautiful - Ugly: African and Diaspora Aesthetics, edited by Sarah Nuttall, 60-93. Durham: Duke University Press, 2006.

McCall, Leslie. "The Complexity of Intersectionality." Signs: The Journal of Women in Culture and Society 30, no. 3 (2005): 1771-1800.

McClintock, Anne. "Family Feuds: Gender, Nationalism and the Family." Feminist Review 44 (1993): 61-80.

McClintock, Anne. Imperial Leather: Race, Gender and Sexuality in the Colonial Contest. New York: Routledge, 1995.

McClintock, Anne. “'No Longer in Future Heaven': Women and Nationalism in South Africa." Transition 51 (1991): 104-123.

McSorley, Kevin. "War and the Body." In War and the Body: Militarisation, Practice and Experience, edited by Kevin McSorley, 1-39. London: Routledge, 2012.

Medeiros, Eduardo da Conceição. História de Cabo Delgado e do Niassa (C 1836-1927). Maputo: Central Impressora, 1997.

Meier, Barbara, and Arne S. Steinforth, eds. Spirits in Politics: Uncertainties of Power and Healing in African Societies. Frankfurt: Campus Verlag, 2013.

Meneses, Maria Paula. "Xiconhoca, o inimigo: narrativas de violência sobre a construção da nação em Moçambique.” Revista Crítica de Ciências Sociais 106 (2015): 9-51.

Merleau-Ponty, Maurice. Phenomenology of Perception. Translated from French by Colin Smith. London: Routledge, 2002. Originally published as Phénoménologie de la perception (Paris: Gallimard, 1945).

Middleton, David, and Derek Edwards. "Conversational Remembering: A Social Psychological Approach." In Collective Remembering, edited by David Middleton and Derek Edwards, 23-45. London: Sage Publications, 1990.

Middleton, David, and Derek Edwards. "Introduction." In Collective Remembering, edited by David Middleton and Derek Edwards, 1-22. London: Sage Publications, 1990.

Millar, Susanna. "Network Models for Haptic Perception." Infant Behavior \& Development 28, no. 3 (2005): 250-265.

Miller, Tina, and Linda Bell. "Consenting to What? Issues of Access, Gate-Keeping and 'Informed' Consent." In Ethics in Qualitative Research, edited by Tina Miller, Maxine Birch, Melanie Mauthner, and Julia Jessop, 61-76. London: SAGE, 2012.

Ministério da Administração Estatal. Perfil do distrito de Mavago província de Niassa. Maputo: Ministério da Administração Estatal, 2005. Accessed March 26, 2016. www.portaldogov erno.gov.mz/por/Mocambique/Geografia-de-Mocambique/Provincias-e-Distritos.

Mitchell, James Clyde. The Yao Village: A Study in the Social Structure of a Nyasaland Tribe. Manchester: Manchester University, 1956. 


\section{Bibliography}

Moghadam, Valentine M."Gender and Revolutions.” In Theorizing Revolutions: New Approaches from Across the Disciplines, edited by John Foran, 133-162, London: Routledge, 1997.

Mohanty, Chandra Talpade. Feminism without Borders: Decolonizing Theory, Practicing Solidarity. Durham: Duke University Press, 2003.

Mohanty, Chandra Talpade. "Under Western Eyes: Feminist Scholarship and Colonial Discourses." In Third World Women and the Politics of Feminism, edited by Chandra Talpade Mohanty, Ann Russo, and Lourdes Torres, 51-80. Indianapolis: Indiana University Press, 1991.

Moiane, José Phahlane. Memórias de um guerrilheiro. Maputo: King Ngungunyane Institute, 2009.

Molyneux, Maxine. "Mobilization without Emancipation? Women's Interests, State, and Revolution." In Transition and Development: Problems of Third World Socialism, edited by Richard R. Fagen, Carmen Diana Deere, and Jose Louis Coraggio, 280-302. New York: Monthly Riview Press, 1986.

Mondlane, Eduardo. The Struggle for Mozambique. Middlesex: Penguin Books, 1969.

Morris, David B. The Culture of Pain. Berkeley: University of California Press, 1993.

Município de Lichinga, Conselho Municipal da Lichinga. "Perfil do Município de Lichinga," Lichinga, 2011.

Munslow, Barry. Mozambique: The Revolution and Its Origins. London: Longman, 1983.

Nagel, Joane. "Masculinity and Nationalism: Gender and Sexuality in the Making of Nations." Ethnic and Racial Studies 21, no. 2 (1998): 242-269.

Nardi, Sarah De. The Poetics of Conflict Experience: Materiality and Embodiment in Second World War Italy. London: Routledge, 2017.

Nash, Catherine. "Performativity in Practice: Some Recent Work in Cultural Geography." Progress in Human Geography 24, no. 4 (2000): 653-664.

Ncomo, Barnabé. Uria Simango: um homem, uma causa. Maputo: Edições Novafrica, 2003.

Ndegue, David Francisco Xadreque. A luta de libertação na frente do Niassa. Vol. 1. Maputo: JV Editores, 2009.

Neil-Tomlinson, Barry. “The Nyassa Chartered Company: 1891-1929.” The Journal of African History 18, no. 1 (1977): 109-128.

Newitt, Malyn. A History of Mozambique. London: Hurst and Company, 1995.

Ngunga, Armindo, and Osvaldo G. Faquir. Padronização da ortografia de línguas moçambicanas: relatório do III seminário. Maputo: CEA, 2011.

Nhongo-Simbanegavi, Josephine. For Better or Worse: Women and ZANLA in Zimbabwe's Liberation Struggle. Harare: Weaver, 2000.

“Niassa: aqui começa Moçambique novo.” O Jornal (Lisbon), October 7, 1983. Accessed March 26, 2016. www.mozambiquehistory.net/history/operacao_producao/19831007_ niassa_is_new_mozambique.pdf.

Nihia, Eduardo. M'toto: combatente pela liberdade. Maputo: UEMA, 2016.

Nordstrom, Carolyn. A Different Kind of War Story. Philadelphia: University of Pensylvania, 1997.

Norkunas, Martha. "The Vulnerable Listener." In Oral History off the Record: Towards an Ethnography of Practice, edited by Anna Sheftel and Stacey Zembrzycki, 81-96. New York: Palgrave Macmillan, 2013.

Northrup, Nancy. "The Migrations of Yao and Kololo into Southern Malawi: Aspects of Migrations in Nineteenth Century Africa." The International Journal of African Historical Studies 19, no. 1 (1986): 59-79.

Nuttall, Sarah. "Introduction: Rethinking Beauty." In Beautiful - Ugly: African and Diaspora Aesthetics, edited by Sarah Nuttall, 6-29. Durham: Duke University Press, 2006. 
Nuttall, Sarah, and Achille Mbembe, eds. Johannesburg: The Elusive Metropolis. Durham: Duke University Press, 2008.

Oestigaard, Terje. "Witchcraft, Witch Killings and Christianity: The Works of Religion and Parallel Cosmologies in Tanzania." In Looking Back, Looking Ahead: Land, Agriculture and Society in East Africa: A Festschrift for Kjell Havnevik, edited by Michael Ståhl, 182-199. Uppsala: The Nordic Africa Institute, 2015.

Oficína de História, CEA. “A produção nas zonas libertadas.” In Não vamos esquecer!: boletim informativo da oficína de história, edited by Yussuf Adam, 4: 24-28. Maputo: CEA, 1987.

Oficína de História, CEA. "Resenha histórica sobre as zonas libertadas-a experiência da província do Niassa." In Não vamos esquecer!: boletim informativo da oficína de história, edited by Yussuf Adam, 4: 13-18. Maputo: CEA, 1987.

Okello, Elialilia S., and Solvig Ekbland. "Lay Concepts of Depression among the Baganda of Uganda: A Pilot Study." Transcultural Psychiatry 43, no. 2 (2006): 287-313.

Oksala,Johanna. "Female Freedom: Can the Lived Body be Emancipated?” In Feminist Interpretations of Maurice Merleau-Ponty, edited by Dorothea Olkowski and Gail Weiss, 209-228. University Park, PA: The Pennsylvania State University Press, 2006.

Oksala, Johanna. "A Phenomenology of Gender." Continental Philosophy Review 39 (2006): 229-244.

Omar, Lúcia Laurentina, and Alexandre António. As dinastias Mataaka (Sec. XIV-XX). Maputo: ARPAC-Instituto de Investigação Sócio-Cultural, 2004.

OMM and Zimba, Benigna. A mulher moçambicana na luta de libertação nacional: memórias do destacamento feminino. Maputo: CPHLLN, 2012.

Organização da Mulher Moçambicana (hereafter OMM). "Relatório da Comissão Coordenadora Nacional da Organização da Mulher Moçambicana à II Conferencia da O.M.M." In Documentos da II Conferencia da Organização da Mulher Moçambicana, 29-63. Maputo: Imprensa Nacional, 1977.

“Osvaldo Assahel Tazama." In Protagonistas da luta de libertação nacional, compiled and edited by Ana Bouene Mussanhane, 617-629. Maputo: Marimbique, 2012.

Owen, Hilary. Mother Africa, Father Marx: Women's Writings of Mozambique 1948-2002. Lewisburg: Bucknell University Press, 2007.

Oyěwùmí, Oyèrónké. "Conceptualizing Gender: Eurocentric Foundations of Feminist Concepts and the Challenge of African Epistemologies." In African Gender Scholarship: Concepts, Methodologies and Paradigms, edited by Signe Arnfred, Bibi Bakare-Yusuf, Edward Waswa Kisiang'ani, Desiree Lewis, Oyèrónké Oyěwùmí, and Filomina Chioma Steady, 1-8. Dakar, Senegal: Council for the Development of Social Science Research in Africa, 2004.

Oyěwùmí, Oyèrónké. "Decolonizing the Intellectual and the Quotidian: Yorùbá Sholars(hip) and Male Dominance." In Gender Epistemologies in Africa: Gendering Traditions, Spaces, Social Institutions, and Identities, edited by Oyèrónké Oyěwùmí, 1-30. New York: Palgrave Macmillan, 2011.

Oyěwùmí, Oyèrónké. The Invention of Women: Making an African Sense of Western Gender Discourses. London: University of Minnesota, 1997.

Pallasmaa, Juhani. The Eyes of the Skin: Architecture and the Senses. Chichester: Wiley-Academy, 2005.

Panzer, Michael G. "The Pedagogy of Revolution: Youth, Generational Conflict, and Education in the Development of Mozambican Nationalism and State, 1962-1970." Journal of Southern African Studies 35, no. 4 (2009): 803-820.

Paredes, Margarida. Combater duas vezes: mulheres na luta armada em Angola. Vila do Conde: Verso da História, 2015. 
Parkins, Wendy. "Protesting like a Girl: Embodiment, Dissent and Feminist Agency." Feminist Theory 1 (2000): 59-78.

Partido Frelimo. Simpósio 50 anos da Frelimo (1962-2012): fontes para nossa história. Maputo: CPHLLN, 2012.

Passerini, Luisa. "Memories Between Silence and Oblivion." In Contested Pasts: The Politics of Memory, edited by Katherine Hodgkin and Susannah Radstone, 238-254. London: Routledge, 2003.

Patel, Vikram. Culture and Common Mental Disorders in Sub-Saharan Africa. New York: Psychology Press, 1998.

Paterson, Mark. The Senses of Touch: Haptics, Affects and Technologies. Oxford: Berg, 2007.

Paterson, Mark, Martin Dodge, and Sara MacKian. "Introduction: Placing Touch within Social Theory and Empirical Study." In Touching Place, Placing Touch, edited by Mark Paterson and Martin Dodge, 1-28. Aldershot: Ashgate, 2012.

Peirone, Frederico José. Tribo Ajaua do Alto Niassa (Moçambique) e alguns aspectos da sua problemática neo-islâmica. Lisbon: Instituto de Investigação Científica Tropical (IICT), 1967.

Pelembe, João Facitela. Lutei pela pátria: memórias de um combatente da luta pela libertação nacional. Maputo: SGL, 2012.

Piot, Charles. Remotely Global: Village Modernity in West Africa. Chicago: University of Chicago Press, 1999.

Pitcher, M. Anne. "Conflict and Cooperation: Gendered Roles and Responsibilities within Cotton Households in Northern Mozambique." African Studies Review 39, no. 3 (1996): 81-112.

Pitcher, M. Anne. "Disruption without Transformation: Agrarian Relations and Livelihoods in Nampula Province, Mozambique 1975." Journal of Southern African Studies 24, no. 1 (1998): 115-140.

Pitcher, M. Anne. Transforming Mozambique: The Politics of Prizvatization, 1975-2000. Cambridge: Cambridge University Press, 2002.

Popular Memory Group, ed. Interpreting Women's Lives: Feminist Theory and Personal Narratives. Bloomington: Indiana University Press, 1989.

Portelli, Alessandro. The Death of Luigi Trastulli and Other Stories: Form and Meaning in Oral History. Albany, NY: State University of New York, 1991.

Portelli, Alessandro. "The Massacre at Civitella Val di Chiana (Tuscany, June 29, 1944): Myth and Politics, Mourning and Common Sense." In Battle of Valle Giulia, edited by Alessandro Portelli, 140-160. Madison: The University of Wisconsin Press, 1997.

Presley, Cora Ann. Kikuyu Women, the Mau Mau Rebellion, and Social Change in Kenya. Boulder, CO: Westview Press,1992.

Puri, Jyoti. Encountering Nationalism. Oxford: Blackwell, 2004.

Raimundo, José Alberto. "Frente do Niassa." In História da luta de libertação nacional, edited by Joel das Neves Tembe, 453-550. Vol. 1. Maputo: Direcção Nacional de História, Ministério dos Combatentes, 2014.

Ranchod-Nilsson, Sita. “(Gender) Struggles for the Nation.” In Women, States and Nationalism: At Home in the Nation?, edited by Sita Ranchod-Nilsson and Mary Ann Tétreault, 164-180. London: Routledge, 2000.

Ranger, Terence. "African Views of the Land: A Research Agenda." Transformations 44 (2000): 53-62.

Ranger, Terence. “Making Zimbabwean Landscapes.” Paideuma 43 (1997): 59-73.

Ranger, Terence. Voices from the Rocks: Nature, Culture and History in the Matopos Hills of Zimbabwe. Oxford: James Currey, 1999.

Ricœur, Paul. Memory, History, Forgetting. Translated from French by Kathleen Blamey and David Pellauer. London: The University of Chicago Press, 2004. 
Riessman, Cathrine Kohler. "Analysis of Personal Narratives." In Handbook of Interview Research: Context \& Method, edited by Jaber F. Gubrium and James A. Holstein, 695-711. Thousand Oaks: Sage, 2002.

Riley, Denise. The Words of Selves: Identification, Solidarity, Irony. Stanford, CA: Stanford University Press, 2000.

Rodaway, Paul. Sensuous Geographies: Body, Sense and Place. London: Routledge, 1994.

Rose, Gillian. Feminism and Geography: The Limits of Geographical Knowledge. Cambridge: Polity Press, 1993.

Rubin, Deborah S. “'Business Story is Better than Love' Gender, Economic Development, and Nationalist Ideology in Tanzania." In Women Out of Place: The Gender of Agency and the Race of Nationality, edited by Brackette Williams, 245-269. London: Routledge, 1996.

Sandberg, Linn. "Affirmative Old Age — the Ageing Body and Feminist Theories on Difference.” International Journal of Ageing \& Later Life 8, no. 1 (2013): 11-40.

Santos, Ana. "The Past in the Present: Memories of the Liberation Struggle in Northern Mozambique." Paper presented at $7^{\circ}$ Congresso Ibérico de Estudos Africanos, Lisbon, September 2010. Accessed March 26, 2016. http://hdl.handle.net/10071/2248.

Saul, John S. A Difficult Road: The Transition to Socialism in Mozambique. New York: Monthly Review Press, 1985.

Scarry, Elaine. The Body in Pain: The Making and Unmaking of the World. Oxford: Oxford University Press, 1985.

Schafer, Jessica. Soldiers at Peace: Veterans and Society after the Civil War in Mozambique. New York: Palgrave Macmillan, 2007.

Schaffer, Raymond Murray. The Soundscape: Our Sonic Environment and the Tuning of the World. Rochester, VT: Destiny Books, 1994.

Schepher-Hughes, Nancy. "Ire in Ireland.” Ethnography 1, no. 1 (2000): 117-140.

Schmid, Christian. "Henri Lefebvre's Theory of the Production of Space: Towards a ThreeDimensional Dialectic.” In Space, Difference, Everyday Life: Reading Henri Lefebvre, edited by Kanishka Goonewardena, Stefan Kipfer, Richard Milgrom, and Christian Schmid, 27-45. New York: Routledge, 2008.

Schutz, Alfred. The Phenomenology of the Social World. Translated from German by George Walsh and Frederick Lehnert. Evanston, IL: Northwestern University Press, 1967. Originally published as Der sinnhafte aufbau der sozialen welt (Vienna: Springer-Verlag, 1932).

Scott, Joan W. "Gender: A Useful Category of Historical Analysis." The American Historical Review 91, no. 5 (1986): 1053-1075.

Seamon, David. "Body-Subject, Time-Place Routines, and Place-Ballets." In The Human Experience of Space and Place, edited by Anne Buttimer and David Seamon, 148-165. London: Croom Helm, 1980.

Sellström, Tor. Sweden and National Liberation in Southern Africa. Vol. 2: Solidarity and Assistance 1970-1994. Uppsala: The Nordic Africa Institute, 2002.

Sepänmaa, Yrjö. "Face to Face with the Landscape.” In Koht ja Paik/Place and Location, edited by Kaia Lehari and Virve Sarapik, 11-20. Tallinn: Proceedings of the Estonian Academy of Arts 8, 2000.

Seremetakis, C. Nadia. "The Memory of the Senses, Part 1: Marks of the Transitory." In The Senses Still: Perception and Memory as Material Culture in Modernity, edited by C. Nadia Seremetakis, 1-18. London: University of Chicago Press, 1996.

"Sérgio Vieira, Governador do Niassa, a "O Jornal": uma das consequências da Operação Produção será o desenvolvimento do português." O Jornal (Lisbon), October 7, 1983. Accessed March 26, 2016. www.mozambiquehistory.net/history/operacao_producao/ 19831007_sergio_says_portuguese_will_develop.pdf. 


\section{Bibliography}

Sheldon, Kathleen. "II Studied with the Nuns, Learning to Make Blouses': Gender Ideology and Colonial Education in Mozambique." The International Journal of African Historical Studies 31, no. 3 (1998): 595-625.

Sheldon, Kathleen. Pounders of Grain: A History of Women, Work, and Politics in Mozambique. Portsmouth, NH: Heinemann, 2002.

Sheldon, Kathleen. “'To Guarantee the Implementation of Women's Emancipation as Defined by the Frelimo Party': The Women's Organization in Mozambique." Working Paper 206, Michigan State University, May 1990.

Sheldon, Kathleen. "Women and Revolution in Mozambique: A Luta Continua." In Women and Revolution in Africa, Asia and the New World, edited by Mary Ann Tetreault, 33-55. Columbia: University of South Carolina, 1994.

Sheldon, Kathleen, and Isabel P. B. Fêo Rodrigues. "Outras Vozes: Women's Writings in Lusophone Africa.” African and Asian Studies 7 (2008): 423-445.

Shetler, Jan Bender. Imagining Serengeti: A History of Landscape Memory in Tanzania from Earliest Times to the Present. Athens: Ohio University Press, 2007.

Silveira da Costa, Camilo Manuel. O Niassa visto por dentro. Lisboa: Boletem Geral do Ultramar, 1959.

Silvey, Rachel. "Power, Difference and Mobility: Feminist Advances in Migration Studies." Progress in Human Geography 28, no. 4 (2004): 1-17.

Simms, Eva-Maria, and Beata Stawarska. "Introduction: Concepts and Methods in Interdisciplinary Feminist Phenomenology." Janus Head 13, no. 1 (2014): 6-16.

Simone, AbdouMaliq. For the City Yet to Come: Changing African Life in Four Cities. London: Duke University Press, 2004.

Smith, Robin James, and Kevin Hetherington. "Urban Rhythms: Mobilities, Space and Interaction in the Contemporary City." The Sociological Review 61, no. S1 (2013): 4-16.

Soiri, Iina. Radical Motherhood and Awakening Gender Awareness: Namibian Women's Independence Struggle. Helsinki: Helsingin yliopisto, 1994.

Souto, Amélia Neves de. "Memory and Identity in the History of Frelimo: Some Research Themes." Kronos 39, no. 1 (2013): 280-296.

Spivak, Gayatri Chakravorty. A Critique of Postcolonial Reason: Toward a History of the Vanishing Present. London: Harvard University Press, 1999.

Spivak, Gayatri Chakravorty. "Criticism, Feminism, and the Institution.” In The Post-Colonial Critic: Interviews, Strategies, Dialogues, edited by Sarah Harasym, 1-16. New York: Routledge, 1990.

Stacey, Judith. "Can There Be a Feminist Ethnography?” Women's Studies International Forum 11, no. 1 (1988): 21-27.

Stannus, Hugh S. "The Wayao of Nyasaland.” In Harvard African Studies, edited by E. A. Hooton and N. I. Bates, 229-372. Vol. 3. Cambridge, MA: Harvard University Press, 1922.

Steinforth, Arne S. "Whose Madness? Diverging Manifestations of Mental Illness in Dialogue." Curare 32, no. $1+2$ (2009): 96-105.

Stokoe, Elizabeth H. "Gender and Discourse, Gender and Categorization: Current Developments in Language and Gender Research." Qualitative Research in Psychology 1, no. 2 (2004): 107-129.

Stoller, Silvia. "Expressivity and Performativity: Merleau-Ponty and Butler." Continental Philosophy Review 43, no. 1 (2010), 97-110.

Sumich, Jason. “'An Imaginary Nation' Nationalism, Ideology \& the Mozambican National Elite." In Sure Road? Nationalisms in Angola, Guinea-Bissau and Mozambique, edited by Eric Morier-Genoud, 127-148. Leiden: Brill, 2012.

Tamale, Sylvia. "Eroticism, Sensuality and "Women's Secrets" Among the Baganda: A Critical Analysis." Feminist Africa 5 (2005): 9-36. 
Thorold, Alan. "Metamorphosis of the Yao Muslims." In Muslim Identity and Social Change in Sub-Saharan Africa, edited by Louis Brenner, 79-90. Indianapolis: Indiana University, 1993. Thorold, Alan. “The Persistence of a Tribe.” Alternation 2, no. 2 (1995): 74-89.

Tilley, Christopher. A Pheomenology of Landscape: Places Paths and Monuments. Oxford: Berg, 1994. Townsend, Leslie H. “Interactive Women's Life Histories." History in Africa 17 (1990): 351-358. Trnka, Susanna, Christine Dureau, and Julie Park, eds. Senses and Citizenships: Embodying Political Life. London: Routledge, 2013.

Tronto,Joan C."Women and Caring: What Can Feminists Learn about Morality from Caring?" In Gender/Body/Knowledge: Feminist Reconstructions of Being and Knowing, edited by Alison M. Jaggar and Susan R. Bordo, 172-187. New Brunswick: Rutgers University Press, 1989.

Truax, Barry. Acoustic Communication. London: Ablex Publishing, 2001.

Tuan, Yi-Fu. "Language and the Making of Place: A Narrative-Descriptive Approach." Annals of the Association of American Geographers 81, no. 4 (1991): 684-696.

Tuan, Yi-Fu. "Sense of Place: Its Relationship to Self and Time." In Reanimating Places: A Geography of Rhythms, edited by Tom Mels, 45-55. Aldershot: Ashgate, 2004.

Tuan, Yi-Fu. Space and Place: The Perspective of Experience. Minneapolis: University of Minnesota, 1977.

Urdang, Stephanie. And Still They Dance: Women, War and the Struggle for Change in Mozambique. New York: Monthly Review Press, 1989.

Urdang, Stephanie. Fighting Two Colonialism: Women in Guinea-Bissau. London: Monthly Review Press, 1979.

Urry, John. "Connections.” Environment and Planning D, no. 22 (2004): 27-37.

Utas, Mats. "Victimacy, Girlfriending, Soldiering: Tactic Agency in a Young Woman's Social Navigation of the Liberian War Zone." Anthropological Quarterly 78, no. 2 (2005): 403-430.

Vail, Leroy."Mozambique's Chartered Companies: The Rule of the Feeble." Journal of African History 17, no. 3 (1976): 389-416.

Van Damme, Wilfried. Beauty in Context: Towards an Anthropological Approach to Aesthetics. Köln: Brill, 1996.

Vance, Carole S. "Pleasure and Danger: Toward a Politics of Sexuality." In Pleasure and Danger: Exploring Female Sexuality, edited by Carole S. Vance, 1-27. London: Pandora Press, 1989.

Von Sicard, S. "Islam in Mozambique: Some Historical and Cultural Perspectives." Journal of Muslim Minority Affairs 28, no. 3 (2008): 473-490.

Waetjen, Thembisa. "The Limits of Gender Rhetoric for Nationalism: A Case Study from Southern Africa." Theory and Society 30, no. 1 (2001): 121-152.

Wegher, Luís. Um olhar sobre o Niassa. Vol. 2. Maputo: Paulinas Editorial, 1999.

Weiss, Gail. Body Images: Embodiment and Intercorporeality. London: Routledge, 1999.

West, Harry G. "Girls with Guns: Narrating the Experience of War of Frelimo's 'Female Detachment."” Anthropological Quarterly 73, no. 4 (2000): 180-194.

West, Harry G. Kupilikula: Governance and the Invisible Realm in Mozambique. London: The University of Chicago Press, 2005.

White, Luise. "Anthologies of Women in Africa." Canadian Journal of African Studies 28, no. 1 (1994): 127-133.

Young, Iris Marion. “Throwing like a Girl: A Phenomenology of Feminine Body Comportment, Motility, and Spatiality." In On Female Body Experience: "Throwing like a Girl" and Other Essays, edited by Iris Marion Young, 27-45. New York: Oxford University Press, 2005.

Yuval-Davis, Nira. Gender \& Nation. London: SAGE, 1997.

Zawangoni, Salvador André. A FRELIMO e a formação do homem novo (1964-1974 e 19751982). Maputo: CIEDIMA, 2007. 


\section{Bibliography}

Zimba, Benigna. “'Achivanjila I' and the Making of the Niassa Slave Routes.” In Slave Routes and Oral Tradition in Southeastern Africa, edited by Benigna Zimba, Edward Alpers, and Allen Isaacman, 219-251. Maputo: Filsom Entertainment, 2005.

Zimba, Benigna. Mulheres invisiveis: o género e as políticas comerciais no cul de Moşambique, 17201830. Maputo: Promedia, 2003.

Žižek, Slavoj. The Sublime Object of Ideology. London: Verso, 1989.

\section{Interviews}

\section{Interviews with DFs}

Adiana Matola, Muembe district, March 16,2013, and June 11, 2013 (2 interviews same day). Amélia Omar, Lichinga, November 29, 2012, November 30, 2012, December 6, 2012, and August 12, 2013.

Amina Ndaala, Lichinga, February 20, 2013, March 24, 2013, July 5, 2013, and June 23, 2014. Ana Alane, Lichinga, February 7, 2013, February 18, 2013, March 9, 2013, and July 28, 2013. Assiato Muemedi, Sanga district, May 8, 2013, June 25, 2013, and August 5, 2013.

Beatriz Assima, Lichinga, January 23, 2013, January 30, 2013, February 8, 2013, and February 20, 2013.

Bendita N'tuma, Lichinga, February 2, 2013, February 4, 2013, February 11, 2013.

Carolina Saide, Lichinga, February 4, 2013, February 11, 2013, and July 31, 2013.

Catarina Mbuana, Mavago district, May 11, 2013, and June 24, 2013.

Celina Saide, Mavago district, May 8, 2013, June 27, 2013, August 7, 2013, and June 4, 2014.

Fátima Aide Namboka, Sanga district, February 12, 2013, February 13, 2013, and July 22, 2013.

Fátima Aquili, Lichinga, November 23, 2012, November 28, 2012, December 4, 2012, and June 6, 2013.

Fátima Buanade, Muembe district, December 13, 2012, March 13, 2013, June 13, 2013, and June 14, 2013.

Fátima Issa Chipande, Mavago district, May 11, 2013, June 27, 2013, and August 7, 2013.

Fátima Omar Mombajia, Lago district, July 2, 2013, July 30, 2013, and August 13, 2013.

Fátima Saide Assume, Muembe district, December 12, 2012, December 13, 2012, March 13, 2013, and June 13, 2013.

Fátima Walusa, district of Lichinga, January 29, 2013, February 5, 2013, and March 20, 2013.

Fátima Wesje, Muembe district, December 14, 2012, March 16, 2013, and June 10, 2013.

Helena Baide, Lichinga, November 21, 2012, November 26, 2012, December 5, 2012, August 24, 2013, and May 23, 2014.

Helena Caisse, Sanga district, June 1, 2013, July 21, 2013 (2 interviews same day), and June 10, 2014.

Lúcia Ali Abdala, Sanga district, February 15,2013, May 30, 2013, July 19, 2013, and June 9, 2014.

Lúcia Bala, Mavago district, May 9, 2013, June 26, 2013, August 9, 2013, and June 1, 2014.

Madalena Bitete, Lago district, July 2, 2013, July 30, 2013, and August 13, 2013.

Madiatu Issa, Sanga district, February 12, 2013, February 13, 2013, June 1, 2013, and June 10, 2014.

Maria Ajaba, Lichinga, November 23,2012, November 28, 2012, January 30, 2013, August 18, 2013, and June 19, 2014.

Maria Issa, Sanga district, July 1, 2013, and August 15, 2013 (2 interviews same day). 
Maria Kambongwe, Lichinga, February 1, 2013, February 23, 2013, and July 5, 2013.

Maria Mota, Lichinga, July 4, 2013, July 27, 2013, and August 21, 2013.

Maria Yassine, Lichinga, February 21, 2013, March 25, 2013, and July 10, 2013.

Rosa Chalamanda, Mavago district, May 9, 2013, June 26, 2013, and August 6, 2013.

Rosa Mustaffa, Muembe district, December 14, 2012, March 15, 2013, June 12, 2013, and May 30, 2014.

Rosa Namate, Sanga district, February 15, 2013, May 30, 2013, and July 17, 2013.

Rosa Saide, Lichinga, May 23, 2013, June 5, 2013, and June 19, 2013.

Rosa Salimu, Lichinga, February 7, 2013, February 18, 2013, and July 4, 2013.

Teresa Bernardo Macotoa, Sanga district, May 27, 2013, May 28, 2013, July 16, 2013, and June 7,2014.

\section{Interviews with milicianas}

Adimbile Saide, Muembe district, December 12, 2012.

Fátima Saide Mwemedi, Muembe district, December 12, 2012.

Laissa Yassine Mbeja, Muembe district, December 12, 2012.

Lukia Mwemedi, Muembe district, December 12, 2012.

Verónica Solamoyo, Sanga district, May 28, 2013.

\section{Interviews with male ex-combatants}

Bernardo Moisés Goy-Goy, Lichinga, November 20, 2012 and August 23, 2013.

Eduardo da Silva Nihia, Maputo, July 2, 2014.

Group interview with Andre Ambrózio, Makolombela, and Jadi Assani, Lichinga, August 14, 2013.

Group interview with Amido Cimanje, Mwemedi Alifa, and Mwemedi N'tawula, Mavago district, August 8, 2013.

Group interview with Bakari Mario Saide and Opesi Saide, Sanga district, July 22, 2013.

Group interview with Cassimo Dilondo, Mawasi Assane, and Raul Candulo, Muembe district, June 14, 2013.

Group interview with Fernardo Mbuana Chibakuli and Rajabo Aly, Sanga district, July 17, 2013.

Tito Brás Cassimo, Lichinga, June 19, 2014.

\section{Interviews with government and ACLLN representatives}

Ajuda de Esperança Docotal, ACLLN representative in Muembe district, Muembe sede, May 29, 2014.

Genoveva Garoupa, national director of integration of combatants at the Ministry of Combatants (MICO), Maputo, July 3, 2014.

Horácio Massangaye, national director of social assistance at MICO, Maputo, July 2, 2014.

Isaias Aquimo, the director of the provincial office of MICO in Niassa, Lichinga, June 23, 2014.

Jaime Assene, secretary of ACLLN in the Sanga district, Malulu, June 10, 2014.

Joaquina Joado, ACLLN representative in Mavago, Mavago sede, June 4, 2014.

Matteus Saide, secretary of ACLLN in Lichinga, Lichinga, August 23, 2013. 
Mussa Ausse and Bernardo João Zuber, ACLLN representatives in Matchedje, Matchedje, June 8, 2014.

Rui Cabinda, the provincial secretary of ACLLN, Lichinga, June 24, 2014.

Smart Edward Katawala, secretary of ACLLN in the Lago district, Metangula, June 12, 2014.

\section{Interviews with elders and chiefs}

Ajika Momadi, Muembe sede, Muembe district, March 14, 2013, and August 23, 2013.

Amadu Issa Makalani, N'kalapa, Mavago district, June 3, 2014.

Asigale N'talika Mataka, Mavago sede, Mavago district, May 10, 2013, June 28, 2013, and June 1, 2014.

Bibi Acivaanjila (A-Cika Matumula) and A-Tasona Cipanda, Majune, Majune district, June 5, 2014.

Bibi A-Kavanjala (Teresinha Wesje), Chiuanjota, Muembe district, June 10, 2013.

Ce-Aaji (Ajissa Saide), Lichinga, February 6, 2013, and August 22, 2013.

Ce-Jemusi (Diksoni Jemusi), Muembe sede, Muembe district, May 27, 2014, and May 28, 2014.

Ce-Kawambuje (Abudu Yamidi), Ligogolo, Muembe district, May 28, 2014.

Ce-Kwilambo (Ajibu Matola Kwilambo), Lichinga, February 25, 2013, and May 18, 2013.

Ce-Mataka (Mohamede Jabali), Mavago sede, Mavago district, June 28, 2013.

Ce-Mussa (Mussa Makuwani), Mussa, district of Lichinga, March 19, 2013, and August 21, 2013.

Ce-N'talika (Metarika Yakaya Mapulume), N'sawisi, Mavago district, June 3, 2014.

Ce-N'tamila (N'tamila Saye) and Ce-Doas (Ndala Yinusa), Chiuanjota, Muembe district, June 11, 2013.

Ce-Omadi (Omadi Dawadi), Malulu, Sanga district, February 14, 2013, and June 1, 2013.

Jaime Kaukuya, Kolongo, district of Lichinga, January 29, 2013, February 5, 2013, and February 19, 2013.

Maputa Alifa Matola, Mavago sede, Mavago district, June 4, 2014.

Ndala DimeDime and Mateus Ali Buanadi, Ligogolo, Muembe district, May 28, 2014.

Sultão Chiuaula (Jon Ajawa), Lichinga, February 6, 2013, and August 22, 2013.

\section{Fundo de documentação da FRELIMO (FRELIMO archives) at Arquivo Histórico de Moçambique (Mozambique Historical Archives; AHM)}

The archives were not organized in 2009 when I visited them and thus no file numbers are included in the references that follow.

Alberto Joaquim Chipande, Deputy Chief of the Department of Defence, Nangade district, to Pascoal Almeida Nhapulo, Deputy Chief of Provincial Operations, April 25, 1972.

"Actas da conferencia realizada no Centro Educacional de Tunduru no mês de fevereiro de 1973," March 7, 1973.

“Destacamento Feminino," Base Provincial de Cabo Delgado, May 24, 1971.

"Drama sobre a emancipação da mulher Moçambicana." Journal do Centro de Preparação Político-Militar Ano II, no. 224 (April 9, 1973): 1-3.

“Relatório mensal abril,” Base Moçambique, May 26, 1971. 


\section{Glossary and abbreviations}

ACLLN Associação dos Antigos Combatentes da Luta de Libertação Nacional, Association of the Former Combatants of the Liberation Struggle

bairro Administrative subdivision of an urban district

capulana A colorful printed cloth women commonly wear wrapped around their waists

casa melhorada Improved house made of clay bricks and zinc roofing. In Ciyaawo: nyumba ga malata

chapa Minivan transport

DF Destacamento Feminino, the female detachment of the FRELIMO army, which also refers to its individual members

FRELIMO Frente de Libertação de Moçambique, Mozambique Liberation Front Frelimo Partido Frelimo, the Frelimo party

machamba Cultivated field in the highland. In Ciyaawo: ngunda, pl. migunda mato Bush. In Ciyaawo: n'tinji

milicianas/os Civilian women/men who assisted the guerrillas during the war Niassa Austral The southern sector of the Niassa military front

Niassa Ocidental The western sector of the Niassa military front

Niassa Oriental The eastern sector of the Niassa military front

OMM Organização da Mulher Moçambicana, Organization of Mozambican Women RENAMO Resistência Nacional Moçambicana, Mozambican National Resistance Renamo Partido Renamo, the Renamo party

ugadi Stiff maize porridge in Ciyaawo

unyago The umbrella term for both male and female initiation rites in Ciyaawo; nsoondo is the female initiation rite 


\section{Transcription symbols}

\begin{tabular}{|c|c|}
\hline Symbol & Meaning \\
\hline & Underlining indicates stress via pitch and/or amplitude \\
\hline WORD & Capital letters indicate especially loud sounds \\
\hline$(\mathrm{XXX})$ & Indicates the transcriber's inability to hear what was said \\
\hline - & An em-dash indicates a false start or a cutoff in speech \\
\hline$\ldots$ & Ellipsis indicates pause in speech \\
\hline word & Italics indicates words and phrases in other languages than English \\
\hline [word] & Square brackets indicate transcriber's description \\
\hline heh & Indicates laughter \\
\hline
\end{tabular}




\section{Index}

Abdallah, Yohannah 18, 21-22, 99

ACLLN 11, 14, 34nn69-70, 55, 75, 121, 180n136

acoustic community $116 \mathrm{nn} 90-91,122 \mathrm{n} 6$

acoustic environment see soundscape aesthetics: aesthetic engagement 126, 184, 216, 232-233; aesthetic experiences 127, 192-193, 196-197; aesthetic quality 182,187 ; aesthetic sensibilities 175, 198, 222, 233; aesthetics in Africa $128 \mathrm{n} 3$; aesthetics of the "bush" 187 , 192, 222, 233; aesthetics of home 187 , 192, 222; aesthetic value 192, 196, 198; body aesthetic 184, 216; environmental aesthetics theory 126-127, 184, 192; negative aesthetics 187, 192, 198-199, 213, 222, 233; positive aesthetics 184, 223; social aesthetics $213,221 \mathrm{n} 108$; Western aesthetics 184, 216n8; see also beauty, beautiful; pleasure; sensory engagement

agency $9,15,42,83,131,154-155$; sexual 157-158

aging 14, 81-82, 88, 117-119, 123n14; see also body

Ahmed, Sara 122, 187

Akawa, Martha 154

Alcoff, Linda 94n24

aldeamento (fortified villages) 97 , 137, 197

Alpers, Edward A. 18, 21, 23-24, 36n98, 38n146, 38n148

Amadiume, Ifi 9

Amaral, Manuel Gama 18

Amudi, Teresa 138, 141, 149, 178n85

ancestors' spirits $21-22,118-119$

Angoni 13, 18, 22, 105

animals 22,105-106, 201, 211, 223; eating and dietary restrictions 108 ; hunting 81 , 208-209, 115n74 anonymity see naming (politics of)

Arnfred, Signe 50, 54, 81, 148, 150, 156, $176 \mathrm{n} 46,177 \mathrm{n} 52$

arrhythmia 127, 215, 228

de Arriaga, Kaúlza 70n20, 98, 101, 107, 111, 114n50; see also Gordian Knot

Arthur, Marie José 52, 66

atmosphere: concept of 182, 184; perception of 187; social 153, 169 attachment: and belonging 112, 121, 126, 199, 222-223, 228, 233

Bacarro, Gaspar 18, 20

Bakare-Yusuf, Bibi 158

Baker, Carolyn D. 57

barracks (army): after independence 53, 166, 168, 193-194; Tanzanian 144

bases, military camps (during the war) 14, 29n8, 53, 96-101, 113n28, 223; Beira 57, 100, 159, 161; Chityale 70n20; female-only 50, 70n20; Katembe 70n20, 211; Katur 64, 98, 138; Lugwalo 104, 107; Lutyambila 70n20; Mbembe 49; Mipoche 70n20; Nakawale 149; Ngaselo 70n20; Ngungunyane 47, 79, 98, 101, 160, 188; N'sawisi 98, 102, 104, 108, 117 , 144-145, 158, 165, 223; N'tiringwe 139,149

beans $18,80,133,168,196,225$

beauty, beautiful: concept of 126,184 , 216n8, 222; and modernity 192, 196, 209; of Mozambique 201-204, 207, 228, 232-233; place/landscape 96, 126-127, 181-182, 182-187, 196-199; see also aesthetics; ugly

Beira 166, 181-182, 216

Berleant, Arnold 126-127, 184, 192, 196, 199, 219n58, 222, 228

Bhabha, Homi 207, 220n88

bibi (queen) 21-22, 81, 114n52 
binary opposition 5-6, 54, 86

blood 110, 150, 200, 222

bodily memory see embodiment

bodily space/spatiality $69,76,79,82$, 130-131, 158, 232, 234

body: conceptualization of the gendered body 8-9; female 76, 81-92; histories 76, 92, 95n68, 228, 232; language 14, 75, 91,102 ; young $14,88,141$; schema 76 , 82-83, 87, 91-93, 93n15, 232; see also rhythms

bombings 101, 105-108, 110-111,114n50, 115n67, 137, 143-145, 164, 179n119, 200, 222-223

Bonate, Liazzat 23-24, 38n146, 72n60, 116 n82

Bragança, Aquino de 72n54

Brinkman, Inge 104-105, 112n7, 113n22

Bruner, Jerome 151-152

bush nurseries, child care centers 2 , 162-165, 179n114

Butler, Judith 8-9, 53, 83, 89, 151, 232

Buttimer, Anne 135

Böhme, Gernot 182

Cabaço, José Luís 68, 73n82

cabana (hut) 101, 106

Cabrita, João M. 217n26

Cahen, Michael 50, 53-54, 145, 226-227

Campbell, Horace 163

capitalist system 42, 48, 51, 192, 204, 207-209, 215-216, 221n107

capulana 23, 88-89, 133, 136, 143, 162, 171,190

Carr, David 119

Casey, Edward S. 93n15

Casimiro, Isabel Maria 3, 48, 54, 67, 71n37, $177 \mathrm{n} 60$

Castree, Noel 221n107

chapa 11-12, 170, 174, 188, 205, 207, 211

Chichava, Sérgio 218n45

chiefs: in colonial times 130-131, 133, 135, 147; female 21-22; and the initiation rite 24, 36n106; and islamization 23-24, $37 \mathrm{n} 135$; in the liberation struggle 101, 105; and oral history 2, 13, 233-234; and Portuguese colonization 24, 26; precolonial chieftaincies and territorial 18, 20-23; see also Mataka

childhood 13, 99, 233; places and homeplaces 130-136, 170-171, 181, 197

Chisholm, Dianne 94n25, 114n48
Cinyanja 4, 33n66, 34n73; see also Nyanja civilians: civilian population during war 29n9, 71n37, 97, 108, 113n28, 137, 161, 163; ex-combatants-civilian relationship $53,68,121,173,214$; return to civilian life 88, 121, 166, 191-192, 215

civil war 3, 103, 117, 178n96, 191, 200, 209, 220n86, 221n104, 224

clothing 23, 95n61; see also capulana; uniform (military)

Coelho, João Paulo Borges 42, 54-55

collective "we" 61-64, 68

collectivism 190-191, 207, 209, 214-215; see also cultivating (farming)

combat 2, 29n8, 47, 52, 64, 88, 92, 106, 115n57, 143, 160-161, 163, 177n58, 179 n104

commemoration 4, 212; ceremonies 68 , $72 \mathrm{n} 55,121$

communal villages 190-191, 193, 197, 215, 218 n 38

community 44n4, 83; DF 12, 158; ex-combatant 4, 11, 68, 116n90, 214-216, 228; national 122, 214; social 121, 215; see also acoustic community

Companhia do Nyassa (Niassa Company) 23-26

comportment (bodily) 85, 88-90

Connell, R.W. 173

cooking 47-48, 52, 80, 89, 109, 149, 185,188

cotton cropping $26,217 \mathrm{n} 14$

Coupland, Nikolas 91

creativity $9,13,17,43,69,76,84,87-88$, $92,95 \mathrm{n} 61,232$

crops 22, 105, 108, 196; cash crops 80, 213; food crops $29 \mathrm{n} 9,80$

cultivating (farming): before the liberation struggle 80-82, 105, 135; collective, communal, and state farms in socialist period 54, 188-191, 207, 215, 218n44; during the liberation struggle $29 \mathrm{n} 9$, 108-109, 112, 145; family fields after independence 125-126, 167-168, 171, 174-175, 196, 201, 207-208, 210-211, 227-228; see also cotton cropping; tobacco cultural script/narrative 9, 69, 129, 145, 233

danger 102, 105, 109, 143, 150, 159-160, 165, 226; sexual 153, 157-158

Dar es Salaam 48-49, 151, 154-156, 159

Davies, Bronwyn 67

death: in war 107, 142, 155, 163; and witchcraft 213, 215, 221n110 
demobilization 88, 166, 179n123, 191, 215

democracy 3, 121

Depelchin, Jacques 72n54

Destacamento Feminino (DF): creation of 49 development (economic): colonial era 26, 136; post-war 199, 201-202, 207-212, 215, 227, 229n10; socialist 189; see also capitalist system

Dhlakama, Afonso 191,199-200

Dinerman, Alice 44n10

Dingemanse, Mark 110

discipline: disciplinary forces of gender ideology 8-9, 225; military 140, 156, $178 \mathrm{n} 88,188$; and the social group 215

divorce 54, 147, 166, 172, 225

Dos Santos, Nuno Beja Valdez Thomaz 98 dwelling 93n7, 198-199, 209-210, 219n62; co-dwelling 215; peaceful 127, 199-200, 210, 215-216, 228

Edwards, Derek 43, 59

Emakhuwa 33n66, 34n73, 144

embodiment: concept of 6-9; embodied experience $76,79,122$; embodied knowledge 76, 88, 92; embodied landscape 6,126, 199; embodied memory 2, 67, 96, 119, 233; see also phenomenology

emotions, feelings: bodily and sensory 75 , 110, 117-120, 228, 232; of happiness 116n79, 119-120; inner 112, 116n79, 182 and language 118 ; negative 14 , 75, 93, 119-121, 192, 219n74, 232; romantic feelings 157; unhappiness and sadness $75,110,118-120,142,144$, 192, 208

Enloe, Cynthia 5, 48, 85, 144, 179n100 ethicsin research 15-16,35n78, 234; ethical representation 17

eurhythmia 215,228

eurhythmic landscape 200

experiential meaning 129, 135, 144, 232

family: FRELIMO's idea of 50, 54, 156, 166, 171, 225; heterosexual 165; life after war 141, 166, 170-173; life before war 136,144 ; life during war 117, 137-142, 144-145; and the matrilineal kinship system $81,135,147,225$; and sense of belonging 222-223, 225; Western concept of 83

famine 18, 22; see also hunger

Fanon, Frantz 83

Farnell, B. 90 fear: of sex 147-149, 157; in and of war 102, 138-139, 200, 224

Ferguson, James 196

Fernardes, Carlos 42

fieldwork 11-15, 22, 152, 159, 185, 228,231

fighter planes, bombers 85, 107, 110-111, $114 \mathrm{n} 40,114 \mathrm{n} 50,137,143,200$

food: in the armed struggle $29 \mathrm{n} 9,107-110$, 114n40, 115n67, 115n70, 115n74, 222; socialist economy and food production 189-191; in the time of independence 167, 170, 200-201, 207, 210, 213; and women's gendered taskscapes 80-82, 131 forgetting 58-59, 62, 73n71, 120, 145, 199, 234 fruits 23, 109

FRELIMO: discourse on women and gender 4, 13, 42, 47-55, 62-63, 66-68, $71 \mathrm{n} 25,81,86,153,163$ (see also women's liberation); family model and politics $156,166,171$; history $28 \mathrm{n} 2,51,54-55$, 69n8, 72n55, 199; narrative 54-55, 68 ; party $54,59,68,79,121$; socialist discourse and politics $3,42,48-51$, 54, 66, 70n24, 92, 122, 173, 190-193, 215-216, 217n32, 225, 234; state 3, 75, 121, 201, 209, 232; wartime nationalist discourse 43, 62-63; wartime political education 50-53, 59, 61-62, 73n73, 136, 141, 157, 173, 190; see also revolution, schools

Galli, Rosemary Elizabeth 112n8, 136 Gaza (province) 171

gender equality: in Ciyaawo 73n78; FRELIMO's concept of 4,50, 52; postwar politics of 54; prewar understanding of 81

Gengenbach, Heidi 130

Germans (military engagement in Niassa) 13, 22, 24, 27, 39n169

Gibson, James J. 103, 219n62

Gordion Knot 113n33

Goy-Goy, Bernardo Moisés 108, 111, 115n89, 149, 176

grandmothers: body schema of 93 ; the role of $81,131,138,141,145,147-148,158,171$

Grosz, Elizabeth 82

haptic: experience of the bush 93, 104, 106, 110, 232; experience of landscape 200; knowledge and way of knowing 103, 114n41; memory 97, 104, 199; sensing 102-104, 114n46, 187 


\section{Index}

healing $119,123 \mathrm{n} 16$

health: centers and bush hospitals during the war 1,117, 149, 191, 207; ill 169; service 26,54 ; sexual and reproductive 150

Heinämaa, Sara 8-9, 32n52, 76, 84, 86-87

Henriksen, Thomas H. 29n10

historiography: FRELIMO 49; Mozambican 42, 48

Howard, Allen M. 7

hunger 107-109, 222

hunting see animals

identity categories 9, 36, 43, 56-57, 65-66, 83, 121, 232-233; age 82, 89, 92-93; gender categories 9, 56, 60, 66-67, 74n87, 83, 86 (see also woman [category of])

ideophones 110,118, 192

Igreja,Victor $221 \mathrm{n} 110$

illness 22, 118, 123n10, 143, 149, 158, 169, 179n132, 215, 221n110, 228

imagination: bodily 127,182 ; geographical 99, 136, 194; sensory 208

immobility 97, 223

in-between, inbetweenness 27, 126, 128n1, 230, 234

Indian Ocean 18, 20, 38n141, 99, 226

Infantário Josina Machel 162-163; see also bush nurseries, child care centers

Ingold, Tim 6, 11, 30n19, 103, 106, 221n62

initiation rites (unhago, jando, nsoondo) 24, 35n79, 36n106, 88, 90-91, 95n64, 111, 131, 133, 145-150, 215; Frelimo's opposition to 54,190

intercorporeality (notion of) 6-7

Islam 7, 21, 23-24, 38n141; Islamic dietary restrictions and regulations 108,111 ; Islamization $37 \mathrm{n} 135$

Israel, Paulo 44n12, 98, 116n83

Johannesburg 99, 226

Johnson, Galen A. 222

Käll, Lisa Folkmarson 8, 31n36, 76

kinesthetic experience 106, 222

Kilwa 18, 20, 36n96, 36n98

Lake Niassa 11, 24, 29n8, 135, 188, 212

Lefebvre, Henri 7-8, 30n19, 32n46, 41, 86, 122n7, 126-127, 129, 200, 204, 209, 215, $228,231,233$

liberation script 42, 54-55

Lichinga 205-208; see also Vila Cabral

Liesegang, Gerhard 20-22, 36n97, 36n104 life: course 82,127,129,135; experiences 14, 28n7, 42-43, 64, 119, 152; history interview 12-15, 152; memories 4, 130, 233; narratives/histories 28n7, 92, 151, 129-130; see also rhythms

LIFEMO (Liga Feminina Moçambicana) 49

lifestyle 127, 182, 187, 191, 192-193, 196, 198, 207, 213-214, 216

lived body 8-9, 232

lived environment 96-97, 112n6, 199

lived experience $6,9,17,48,76,123 \mathrm{n} 14$, 157,232

lived landscape/space 3, 6-8, 31n32, 32n46, 127, 231-232

lived politics 63,67

lobolo 50, 54, 71n30, 190

Lourenço Marques 2, 134

love 141, 156-157, 165, 199

Machava, Benedito Luís 70n24, 190, $218 \mathrm{n} 37,218 \mathrm{n} 46$

Machel, Josina 71n25, 71n31, 150, 179n108, see also Infantário Josina Machel

Machel, Samora 42, 48-49, 51, 65, 71n25, 71n32, 94n41, 108, 150, 153-154, 156, 160, 190-191, 205, 217n30

Majune (district) 34n67, 55, 70n21, 135, 165,176 n 43

Makhuwa 22, 148, 176n46; see also Emakhuwa

Malawi 22-23, 26-27, 37n127, 97, 108, 112, 113n28, 123n10,123n12, 136, 141-142, 170, 182, 226

Manning, Erin 69

Manica (province) 29n8

Maputo: ex-combatants in Maputo $54-56,65,68,96,232$; and ex-combatants' postwar movement 166, 174, 182; and the improdutivos 190-191; research among DFs in Maputo 3-4, 14-16, 49, 55, 69; and spatial difference 2, 43, 199, 202-204, 207, 214-216; see also Lourenço

Marques; Rovuma

marching 52, 102, 105

marriage: experience before the war 146-148, 177n48, 198; and FRELIMO 50, 151, 154-157, 166; marriage after the war 172,180n138, 224-225 and matrilineal kinship 135, 147

Marxist-Leninist ideology (and Frelimo) 54, 189

masculinity: concept of $9,73 \mathrm{n} 75,84,87$, 173; and FRELIMO discourse 48, 52, 86; 
military $86,94 \mathrm{n} 41,160,179 \mathrm{n} 100$; and nationalism 5, 29n14

Massey, Dorren 5-7, 229n19, 231

Mataka 21, 23, 26, 29n8, 90, 97, 114n52, 133, 135

Matchedje (or Congresso) 104, 188, 211-213

Mateus N'kunda, Paulina 55, 61

matrilineal kinship system 20-22, 38n146, $81,135,147-148,225,229 \mathrm{n} 10$

Mavago (district) 29n8, 34n67, 35n74, 70n21, 97, 102, 109, 132, 159, 180n136, 185, 188, 194, 201, 208-209, 211, 217n17

Mavago town 90,102-103,181, 184-187, 212

mbopesi 22, 37n121, 105

McClintock, Anne 5, 165

McSorley, Kevin 67

membership categorization analysis (MCA) $43,56,72 \mathrm{n} 63$

memory and remembering $42-43,72 \mathrm{n} 55$, $119,129,145,200$; collective 59-60, 62, 67, 74n93; nostalgic 3, 96, 191, 215, 227, 232; painful 14, 139, 222; and the senses 97, 105, 110, 115n75, 117, 177n70, 199, 222; social construction of 2, 43, 67-68; see also commemoration; embodiment; forgetting

mental distress see worrying, thinking too much

Merleau-Ponty, Maurice 32n46, 32n49, $76,79,82-84,86,94 \mathrm{n} 30,125,128 \mathrm{n} 1$, $219 \mathrm{n} 62$

Middleton, David 43, 59

miliciana 29n9, 73, 141, 153, 170

military post (Portuguese) 97, 188, 205, 212

military training 2, 4, 49-51, 138-139, 141,145 ; and the DF body 79-80, 84, $87-88$

mines (South African) 26, 99, 136, 176n20

missions: Anglican 18; Catholic 26; education 24, 26, 33n66, 108, 217n31 mobilization (political) 49, 54, 67-68, 92, 108-109, 138, 140, 161-162, 217n27 modernity 190, 192, 196, 208-209, 215-216, 217n31, 227

modernization 190, 192, 204, 207-209, 216, 220n83, 227

Mohanty, Chandra Talpade 17

Moiane, José Phahlane 96, 98, 103, 112n3

Molyneux, Maxine 53

Mondlane, Eduardo 49, 121-122

motherhood 81-82, 130, 145, 158-159, $162-165$; see also grandmothers motility: gendered 80, 82, 87-89, 92, $94 \mathrm{n} 25$

motorbikes 11, 196, 205, 207, 213

mountains 1, 7, 23, 96-98, 101, 104-105, 133, 182, 188, 204

Mozambican woman (the concept of) 42 , $54,56-57,68,70 \mathrm{n} 10,232$

Mozambique Island 20, 36n98, 38n146

Muembe (district) 2, 23, 34n67, 35n74, 170, $185,211,217 \mathrm{n} 17,225,230$

Muembe town 89, 134-135, 186-187

Muslim 23-24, 108; Ayaawo 26, 33n66, 108, 112, 223; see also Islam

Nachingwea (FRELIMO's military training camp) 4, 29n 8, 49, 56-57, 59, 64, 117, 138-141, 143, 164, 177n76

naming (politics of) $15-16$

Nampula 148, 165, 168-171, 174, 202, 211, 224-226

nationalism: FRELIMO 49-51, 54, 69, 233; gender and 3-6, 27, 29n14, 30n17, 76, 231; violence of 232; see also FRELIMO

natural resources 190, 201, 209, 211

Ndegue, David Francisco Xadreque 28n2, 49

Newitt, Malyn 20, 26

Niassa: and its historical landscapes 17-27, 97-98

Niassa Austral 29n8, 64, 70n20, 101

Niassa front of the liberation struggle 4 , 29n8

Niassa National Reserve 184, 209, 220n95

Niassa Ocidental 29n8, 47, 49, 70n20, 79, 101, 116n89

Niassa Oriental 29n8, 29n10, 50, 70n20, 115n53, 115n66, 115n67, 116n89, 117, $138,141,178 \mathrm{n} 85$

Nihia, Eduardo 29n10, 50, 70n23, 108, $115 \mathrm{n} 53,115 \mathrm{nn} 66-67$

noise 13, 110, 116n86, 143, 200, 222

Nordstrom, Carolyn 117

normativity 83-84, 86-89, 91, 94n25, 95n50, 158, 192

Northern Rhodesia 26-27

nostalgia 3, 96, 191, 209, 215, 227, 232

Nyanja 20, 22, 33n66, 36n104; see also Cinyanja

obedience (principle of) 154; disobedience 138

Oficina de História (History Workshop) $44 \mathrm{n} 5,54$

Oksala, Johanna 41, 69, 76, 82-83, 86 
OMM (Organização da Mulher Moçambicana) 42, 48, 51, 54-55, 68, 71n25, 71n37, 156, 174

oppression 228; double 47-49; and

liberation 3, 231; and sexuality 157 ;

women's oppression 41-42, 47-51, 54, 67, 86 (see also women's liberation)

oral history/histories 2, 18, 22-23, 37n121, 39n169, 96-97, 131

Oyewùmí, Oyèrónké 9, 83, 94n26

Pallasmaa, Juhani 103

Paterson, Mark 76, 114n47, 122n5

patriarchies, patriarchal 29n14, 52, 86, 153, 158

patriliny 229n10; Islamic 38n146; patrilineal societies 50

perception: of atmosphere 187; of bodies $76,79,82,92$; of landscape $2,4,7,207$, 226, 232; phenomenology of 219n62 (see also phenomenology); and the senses 31n31, 102-104, 110, 114n39, 114nn46-47, 126, 184, 187, 219n57, 225 (see also haptic)

phenomenology 6, 94n24, 219n62; of the body/embodiment 76,83 ; feminist $8-9$, 31nn31-32, 32n47, 79, 83-84, 231-232

pleasure 14,192; aesthetic 204; sexual 148,157

political commissar 47-48, 51-53, 66-67, $79,134,162$

polygamy 180n138; and FRELIMO 155, 171, 178n86; traveling 81

polyrhythmia: polyrhythmic assemblage 200, 204; polyrhythmic landscape 127 , 199, 233

Portuguese colonization of Niassa 23-27, 97-98

pregnancies $81,147,150-151,154-156$, $159,161,163-165,178 \mathrm{n} 86$; see also motherhood

Quelimane 23,27, 81, 99, 136, 174, 226

Raimundo, José Alberto 28n2

rainy season see seasons

Ranger,Terence 2, 7

reeducation camps 189-191, 217nn26-27, $218 \mathrm{n} 46$

reciprocity 83,222 ; reciprocal relations/ relationships 6-7, 104, 135-136, 146, $172,184,228$

recruitment (military) 4, 49-50, 59, 70n23, 122, 137-139, 141, 143-145, 153, 176 n 27
Renamo (party) 121, 179n125, 200

RENAMO (Resistência Nacional

Moçambicana) 103, 179n125, 191,

194-196, 215, 218n48, 224

respect: as ex-combatant 90-93, 140-141; feminine respectability $89,151,173$;

learning respect in unhago 146; respecting one's body $92,157-158$

revolution 41-42, 156-157; bush as space of 90,198 ; revolutionary discourse 76,92 ; revolutionary experience 51 , 232; revolutionary gender politics 67 ; revolutionary war 50-51, 53, 67, 88 rhythmanalysis $126-127$

rhythms $27,86-87,125-127,160,162$, 173-174, 182, 199-200, 204-205, 233; acoustic 111-112; of the body 122n7, 127, 215, 222, 228; economic 136, 199 , 209, 216; individual and collective 127, 199; life 129-130, 192, 200, 204, 214-215; of the machamba $125,168,188$, 196; social 111, 196, 215-216, 228, 233; urban 204, 207, 227

Ricoeur, Paul 68

Riley, Denise 118

roads $26,97-98,107,188,197,205$, 211-213

Rodaway, Paul 103, 115n77

Rovuma: to Maputo 47, 134, 181, 212-213; River 22, 24, 70n20, 104, 208, 212, 217n20

Rubin, Deborah 66

running (in war) 79-80, 96, 106, 117, 120, 131,162-165, 200, 222

Salazar's Estado Novo 26

Sanga (district) 18, 34n67, 35n74, 112n8, 136, 176n43, 191

Scarry, Elaine 118

Schepher-Hughes, Nancy 16

schools: FRELIMO schools and educational system 138, 141, 144, 199;

Koranic 26; in the socialist period 166-167, 191; see also missions

Schutz, Alfred 67

seasons: dry 170, 196; rainy 106, 145, 174 , 196, 207, 212, 222; seasonal migration 27, 136; time and rhythm 125, 145, 199, 207 security intelligence 101, 159-160, 169 seniority $82,90,93,94 \mathrm{n} 26,141$ sensory engagement 102,128n3, 184, 192 sensory experience $3,76,104,122 \mathrm{n} 5,184$, 200, 222, 228

Sepänmaa,Yrjö 208

Seremetakis, C. Nadia 177n70 
sexuality: FRELIMO and female sexuality 178n99; and marriage 165, 147, 176n46; gender and sexual difference 32n47, 83-84, 86; sex education 146-149; sexual relations and lives in the army 149-158, 177n58 shame 89, 149, 151, 153, 155, 199

Sheldon, Kathleen 54, 217n31

shooting (in war) 52, 110, 142, 149, 160-161, 200

sikiri 111, 116n82

silence 15,110-112, 118-119; silencing 9, 16, 51, 54-55, 72n53, 73n71, 176n22, 177n70 sizala $110-112$

skin $76,94 \mathrm{n} 23,103$; see also touch, tactile perception

slave trade see trade

social constructivism 8-9, 32n 47, 232

social harmony 146, 214, 216

Sofala (province) 29, 182

sorcery: accusations of $217 \mathrm{n} 27$; during the liberation war $114 \mathrm{n} 53$; protective 105 sound 16, 87, 143; ambient 104, 110; and emotion 110, 112, 115n77, 119; intrusive, violent 110-111, 119; see also acoustic community; noise; silence

soundmark 112, 116n90, 223

soundscape 111, 116n87, 116n90, 200

de Souta, Amélia Neves 54, 72n55

South Africa 26-27, 95n62, 99, 136, 176n20, 208, 220n95

Southern Rhodesia 99

space/place/landscape (theorizing) 5-8

space-time 5-6, 231

spatiotemporality 5, 8, 82, 126, 134, 204, 233

Stokoe, Elizabeth H. 72n63

style (of being) 9, 76, 84-87, 90-92, 95n50,

$95 \mathrm{n} 62$; see also lifestyle

supporting population 111, 144

Swahili coast 23-24

taboo $150,177 \mathrm{n} 58$

Tanganyika 38n146, 99, 136

Tanzania 4, 11, 18, 22, 26, 97-99, 104, 108, $112,113 \mathrm{n} 28,115 \mathrm{n} 74,117,132,136$, 139-140, 142, 144, 154, 159-160, 164, 177n $58,184,188,211-213,226$

taste 109, 114n 40, 119-200, 222

taxes: colonial 26-27, 113n10, 136, 226; precolonial 20

Tazama, Osvaldo Assahel 109, 179n104

Tete 18, 29n8, 36n96, 112n8, 202, 211

Thorold, Alan 18, 23, 36n106

time, temporality 5-6, 17, 45n12, 54, 72n67, 76, 220n88, 231; cyclical 106, 111-112, 145, 190, 200; experience of time 106, 111; and rhythm 126, 129, 205-207, 216

tobacco: after the liberation struggle 184 , 217n14, 226; before the liberation struggle 20, 27, 80-81, 99

touch, tactile perception 76, 103-104, 113n35; hurtful and violent 93, 106-107, 192, 200, 215

trade: long-distance 18-20, 36n99, 38n141, 97-99, 113n13; slave 7, 20-23, 37n133

traditional society $42,48,50-51$, 178n99, 190

trails, paths, routes: guerrilla 1, 97-99, 102-103, 107, 109, 138, 140, 144, 160; movement paths 79-80; peacetime 125-126, 224

translation 13, 16-17

transportation see war material

Truax, Barry 110, 116n90

truth 130; and lie 151, 64-66

Tuan,Yi-Fu 135

ugly $126,219 \mathrm{n} 74$; and beautiful 127, 181 , 187,232

Unango Mountain 188, 191, 217n20

Unango (village); 18, 136, 191, 197, 208, 212

uniform (military) 60, 64, 66, 89, 141, 155, $162-163,168,170$

unity $48,87,157$; national $51,61,65-66$; Unity Bridge 212

Vance, Carole S. 129, 153, 157

veteran's pension and benefits 119-120, 123n18, 167-172, 180n136, 197, 201, 207, 213-214, 225-226

Vila Cabral 27, 97, 132, 134, 205; see also Lichinga

voice $16-17,51,54-55,72 n 53,88,90$, 118,122

war material (transportation of) 2, 29n9, 98-99, 105, 141-142, 160-161, 222

weapons (in the liberation struggle) 52, 64, $66,84,99,105,115 \mathrm{n} 75,117,140-143$,

150, 160-165; see also shooting (in war) weather see seasons

Weiss, Gail 8, 82

well-being 34n69, 81, 105, 121, 136, 154 , 175; bodily $199,221 \mathrm{n} 110,228$

West, Harry G. 114n53, 123n16 witchcraft 169, 171, 213; see also sorcery woman (category of) 5, 9, 42, 44n 4, 56-58, $60,68-69,72,83,173$

womanhood: cultural models of 225 ; as a style of being 9,84 


\section{Index}

women's liberation $42,48-51,53,55-56$, 62, 66-67

worrying, thinking too much 117-120, 122n1

youth 75, 90, 201, 227; see also body Young, Iris Marion 83
Zambesi River 20

Zambezia 29n8, 158, 208, 218n45

Zanzibar 23

Zimba, Benigna 55, 36n99, 37n121

Zimbabwe 7, 30n17, 69n6, 179n125

Žižek, Slavoj 121 